
JULY.

VALUABLE LAW WORKS PUBLISERD $\mathbf{B Y}$

STEVENS AND SONS,

LIMITED,

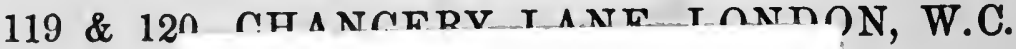

Leake's $\mathbf{E}$

Land. $-S$

"Leake o

Rogers' I

Tration,

and Loca]

Secenteen

1909. I'?

Hood ane

Trustee A

taries. S

Barristers

Farrer's P

Reversion

Appendia

THOMA:

16s. cloth.

Lawes' Ls

By EDW

Irice is. $\mathrm{E}$

Arnould 0:

Eighth Fi

Barristers

Chalmers'

Promissor

Sir M. D

Acts. $D_{e}$

Spencer's :

Explanato

1909. Ir

Spencer's

New Rule:

By AU135

Macdonell

MACDOS

FI)WARI

Ingpen on

Law relati

K.C. lio!

Dicey's Co:

with refel

IIon. I).
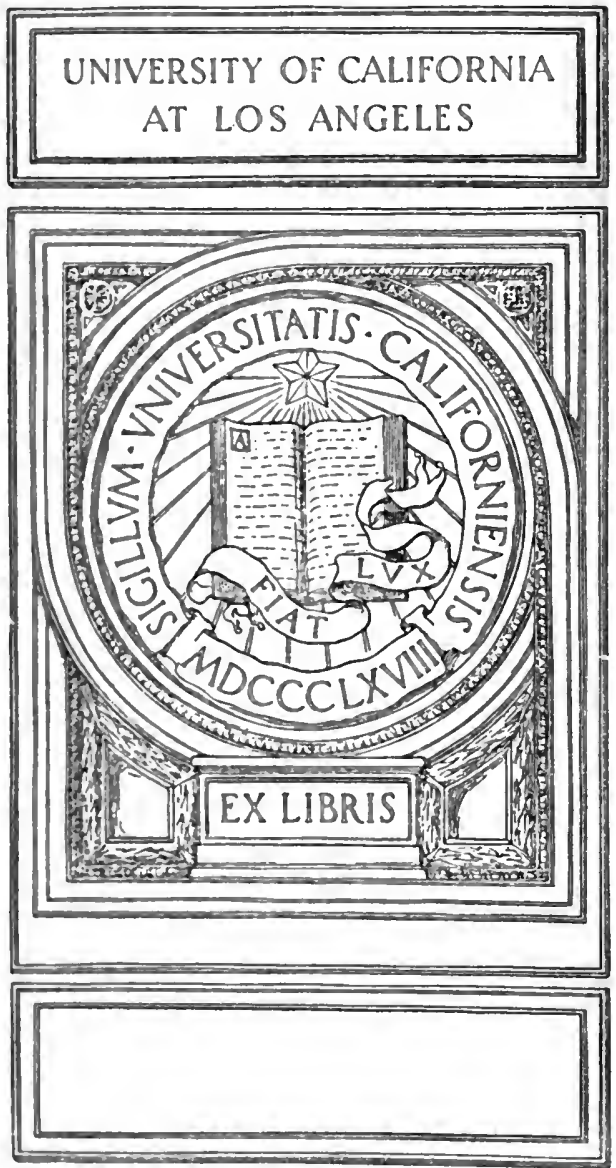

operty in ww, Editor of

I.: Regisiry, Municipal, icil, and Forms. - Royal 12 mo.

and and With Commen I. STIRLING,

al Estate, Chapters, and 'ARRER and 1909. Price

seases. emy 8ro. 1909.

verage. IIFF SIMEY, ixchange, Edition. By 3 of Exchange

908, with w. Dcmy 8 ro.

with the tion, Re-Issue. Price lis. cloth. Sir JoHN d Edition. By : 25s. cloth.

tise on the RT INGPEN, :England DICEY, K.C.,

Freeth's Death Duties. - The Acts relating to the Estate Duty and rother leath Duties. Fourlh Elit. By Sir EVELYN FREETH, Secretary of the Istate linty Oftice, assisted by CIIARLES ROBERT ELLIOTT, of the Estate J)uty Uffice. Ilemy sio. 1908. Frice 12\%. 6l. elnth.

Disney's Law of Carriage by Railway.-Second Edition. By IIEXIRY W. JISNEY, Barrister-at-Law. Itemy tro. 1909. Irice 7s. 6d.cloth. Jolly's Restrictive Covenants affecting Land. - By ï W. AliNoLl JOLLY, Barrister-at-Law. Demy 8vo. 1909. Price 5s. cloth. 
Magistrate's General Practice (The).-A Compendium of the Law and Practice relating to Matters occupying the attention of Courts of Summary Jurisdiction. Re-written and considerably enlarged. By CIIARLFS MILNER ATKINSON, Stipendiary Magistrate for Leeds. Dcmy 8vo. 1909. Price 20s. cloth.

Annual Practice (The), 1909.-Edited by Thomas Sxow, Barrister-at-Law ; CHARLES BCINEY, a Master of the Supreme Court; and F. A. STRINGER, of the Central Office. Two Vols. 8vo. Price, net, 25s. cloth.

* A Thin Paper Edition in One Fol., price, net, 25s., or on India Paper, 3s. 6d. extra.

A, B, C (The) Guide to the Practice of the Supreme Court, 1909.-By FRANCIS A. STRINGER, of the Central Office. Royal 12mo. Price, net, 5s. cloth.

Annual County Courts Practice, 1909.-By His Honour JUDGE SMYLY, K.C., assisted by W. J. BROOKS, Barrister-at-Law. Two lols. Demy 8vo. Price 1l. 5s. cloth.

* A Thin Paper Edition in One Fol., price 258., or on India Paper, 3s. 6d. extra.

Beal's Cardinal Rules of Legal Interpretation.-Second Edit. By EDTWARD BEAL, Barrister-at-Law. Royal 8io. 1908. Price 20s, cloth.

Williams' Law and Practice in Bankruptcy.-Ninth Edition. By EDWARD WM. HANSELL, assisted by A. ROMEIR MACKLIY, Barrister-at-Law. Royal 8ro. 1908. Price 1l. 10s. cloth.

Woodfall's Law of Landlord and Tenant.-With a full Collection of Precedents. Eighteenth Edition. By W. H. AGGS, Barrister-at-Law. Royal 8vo. 1908. Price 1l. 18s. cloth.

Theobald's Concise Treatise on the Law of Wills. - Seventh Edition. By H. S. THEOBALD, K.C. Royal sto. 1908. Price 1l. 15s. cloth.

Macnamara's Law of Carriers of Merchandise and Passengers by Land.-By WALTER HEXRY MACNAMARA, Barrister-at-Luw, Registrar to the Railway Commission, a Master of the Supreme Court. Second Edition. By the AUTHOR and W. A. ROBERTSON, Barrister-at-Law. Roy. Sro. 1908. Price 1l. 10s. cloth.

Robinson's Law relating to Income Tax.-Second Edition. By ARTHUR ROB1NSON, Barrister-at-Law. Royal Svo. 190S. I'rice 25s. cluth.

Wright's French Civil Code, translated into English, with Notes Explauatory and Historical.-By E. IBLACKWOOD WRIGHT, LL.D.. Clief Justice of Seychelles, Author of "The Law of Principal and Agent." Koyal Sto. 190S. Price 25 s. cloth.

Robertson on the Crown. - The Law and Practice of Civil Proceedings by and against the Crown and Departments of the Government. By G. STUART ROBERTSON, Barrister-at-Law. Royal sero. 190s. Irice 1l. 1Ss. cloch.

Decennial Digest (The).-Being the Digest of English Case La's, containing the Reported Decisions of the superior Courts, and a Selection from those of the Scctch and Irish Courts, with a collection of Cases followid,

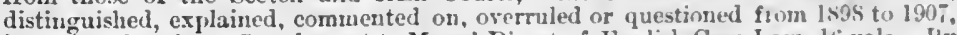
inclusive, forming a Supplement to Mews' Digest of English Case Law, 16 vols. I3y EUWAliD IANSON, Barrister-at-Law. Tico lols. Royal Sro. IYos. Iriee 31. 3 . cluth.

Talbot and Fort's Index of Cases Judicially Noticed, 1865 to 1905.-Second Edition. By II. R. MEHTA, Barrister-at-Law. Royal Sro. 1908. Price 11. 1Ss. cloth.

Emanuel's Law relating to Dogs.-By Moxtagle R. EMANUEL, Barrister-at-Law. Demy 12mo. 1908. I'rice 3s. Gd. cloth. 

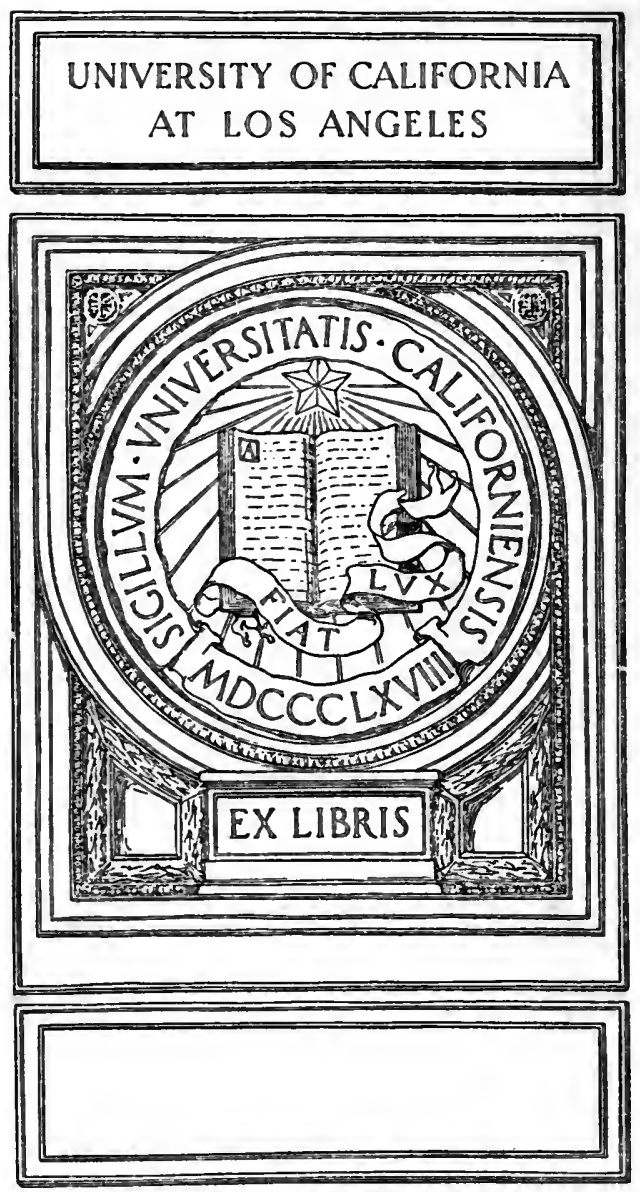


\section{RESPONSIBLE GOVERNMENT IN THE DOMINIONS.}

BY

\section{ARTHUR BERRIEDALE KEITH,}

M.A. (EDIN.); B.A., B.C.x. (OXON.); M.R.A.s.

(Late Boden Scholar in the University of Oxford and Classical Scholar of Balliol College),

OF THE INNER TEMPLE, BARRISTRR-AT-LAW, AND OF THE COLONIAL OFFICE.

Author of "The Theory of State Succession," \&c.

LONDON :

STEVENS AND SONS, LIMITED,

119 \& 120, CHANCERY LANE,

Eavo gublisbers.

1909. 



$$
\begin{aligned}
& J V \\
& 1062 \\
& K 26 r \\
& 1909
\end{aligned}
$$

$\mathcal{T}_{0}$ ftx $\mathfrak{A}$ ftotber.

258264 
Digitized by the Internet Archive in 2007 with funding from Microsoft Corporation 


\section{$(\mathrm{v})$}

\section{PREFACE.}

THIs book is in the main an expansion of material collected by me in preparation for a lecture on the development of colonial self-government in the nineteenth century, which, at the suggestion of Mr. S. Digby, C.I.E., I delivered before the Royal Society of Arts in January, 1908. Todd's classical treatise, even with the valuable additions made by his son, covers the ground only up to 1893 , and, as was pointed out in a recent debate in the House of Assembly in South Australia, politicians of to-day are not likely to accept as valid precedents of the seventies or eighties. Moreover, the last fifteen years have developed in a marked degree the principles of responsible government, and the system, as it now stands, has reached a completeness which renders any advance on the same lines hardly possible. The progress of the future must probably considerably modify the fundamental basis of the present scheme.

The desire for brevity has led to the omission of the discussion of electoral matters, and to the apparent disregard of conflicting opinions held by authorities of great weight. In some cases, too, it 
has led to the sacrifice of literal accuracy in order to permit of the presentation of the facts in a summary form.

As it is my desire to set out the position as it exists, not as it might be, I have, as a rule, refrained from the expression of personal opinions on constitutional points; on undecided questions of law, however, I have not hesitated to express my own views, in the hope of eliciting expressions of opinion from others better qualified to judge than myself.

To the Hon. J. W. Taverner, Agent-General for Victoria, and to the Hon. J. G. Jenkins, formerly Premier and late Agent-General for South Australia, I am glad to express my thanks, both for their kind reception of my lecture and for information which their practical experience of responsible government has enabled them to give me.

\section{A. BERRIEDALE KEITH.}

December, 1908. 


\section{TABLE OF CONTENTS.}

CHAP.

I. The Beginnings of Colonial Self-GovernMENT $\ldots \ldots \ldots \ldots \ldots \ldots \ldots \ldots \ldots \ldots \ldots \ldots \ldots$

II. The Legal Basis of the Dominion Constitu-

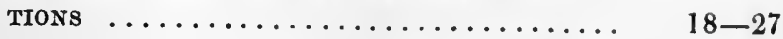

III. The Governor . . . . . . . . . . . . . 28

IV. The Governor and Ministers $\ldots \ldots \ldots \ldots$ 4 40-69

V. Cabinet Governaent in the Doninions ... $\quad 70-80$

VI. The Powers and Privileges of Dominion Legislatures ................ 81-101

VII. Relations between the two Houses of the Legislature .................. 102-132

VIII. The Federations ................ 133-175

IX. Imperial Control of Dominion Legislation and Administration............. 176-221

X. Theaty Rights .... . . . . . . . . . . . . 222-236

XI. The Prerogative of Meroy ......... 237-244

XII. Honovis . . . . . . . . . . . . . . . . 245-254

XIII. Church and State $\ldots \ldots \ldots \ldots \ldots \ldots \ldots$ 255-261

XIV. Judiolal Appeals .............. 262-272

XV. The Judichary ... ............. 273-279

XVI. Imperial Co-operation $\ldots \ldots \ldots \ldots \ldots \ldots$ 280-288 



\section{RESPONSIBLE GOVERNIIENT IN THE DOMINIONS.}

\section{CHAPTER I.}

THE BEGINNINGS OF COLONIAL SELF-GOVERNMENT.

Is the year 1840, when the history of colonial self-government may fairly be said to take a fresh start, the majority of British Colonies were in possession of the form of government known as representative. The history of colonial development. has sometimes been traced as running through a normal development from the Crown Colony form of government, under which the legislative and executive powers are both wielded by the Crown and officers appointed by, and responsible to, the Imperial Government, to the representative stage, in which the legislature is composed of elected representatives of the people, while the executive authority is still in the hands of the Imperial Government, and thence to responsible institutions reproducing as far as possible in the Colonies the forms of ministerial goverument at home. But, in fact, no such symmetry can be traced in colonial history; the earliest form of Constitution has a close resemblance to representative government, and the history of the Colonies is best regarded as either progress from this form to higher things, or regress to Crown Colouy administration. For the system of representative goverument is essentially unstable; it inevitably involves a state of conflict between the executive

$\mathbf{K}$. 
and the legislature, as is indeed seen to-day in all countries in which the full system of a Parliamentary executive is not accepted as part of the Constitution. The legislature, partly elective, partly nominated, found itself unable to enforce its wishes on officials who did not owe their appointment to the colonial legislature, who in many cases were not connected in any way save by their public appointments with the colony, and who could not expect to earn the approval of the Home Government for anything save action conceived in the interests of the United Kingdom. On the other hand, the executive were at the mercy of the legislature as far as supply was concerned, except as regards the short civil list, which was inadequate as a rule even to provide for the salaries of the officials, and which left it entirely to the legislature $(a)$ to provide the funds to carry out the necessary public works and other measures for the benefit of the colony, which the executive felt bound to endeavour to see carried into effect. Every colonial Governor had therefore to devote himself to alternate attempts to bully and cajole the legislature into compliance with his proposals, and in not a few cases Governors were reduced to the expedient of constant dissolutions in the hope, usually vain, of persuading the Assembly to accept their views as an alternative to a fresh appeal to their constituents. Even if a Governor were lucky enough to manage to get along satisfactorily with his legislature, he might find himself at loggerheads with the judiciary, who, though belonging to the same social caste as

(a) In every responsible Government colony the foundation for taxation is, as in England (May, Parl. Practice, ch. xxii.), its necessity for the public service, as declared by the Governor through his Ministers. Lord Durham regarded the absence of such a rule as one of the principal factors in the misgovernment of Canada (Harrison Moore, Commonwealth of Australia, p. 116). It exists in every Crown Colony, but the right of the private member to propose money votes still survives in Bermuda and Bahamas. In Barbados it has been modified by local legislation. 
the executive, were separated from it by professional feeling, and who indeed had often sufficient cause to interfere with the illegal and unwise acts of colonial Governors.

Assuming, however, that a Governor was sufficiently skilful to avoid disputes in the colony, he might find himself involved in troubles with the Home Government, from which he held his office and to which alone he could look for advancement. The control exercised over colonial enactments by Downing Street was minute and irritating; i its extent may be judged that in the years from 1836 to 1864 , of which about twenty fall in the period of self-government, no fewer than three hundred and forty-one Bills were reserved under the Royal Instructions in the North American Colonies alone, and fortyseven of these Bills, for one reason or another, never received the Royal Assent at all. It is perfectly true that in the majority of eases, though by no meaus in all, there was good warrant for this supervision, and that many of the colonial Bills were strangely devoid of prudence, but in many cases it might have been better to leave the colony to buy its own experience, while in others the disallowance was obviously due to an imperfect realisation of the real state of affairs in the Colonies, a defect, however, due in the main to the lack of care taken by Governors in explaining to the Home Government the actual circumstances of the Colonies under their government.

A weak executive and a discontented legislature cannot permanently co-exist, and in the great colowies where there is a large and increasing white population the development of a Parliamentary executive is a natural solution of the problem. But in small islands or in tropical colonies where-there is relatively a large native population circumstanees differ, and the executive can only obtain the necessary strength at the expense of the independence of the legislature. There are very many examples of this process, and historically they are 
interesting in the extreme. In 1840, representative government existed in British Guiana, Jamaica, Grenada, Tobago, St. Vincent, Antigua, Dominica, St Kitts, Nevis, Montserrat, the Virgin Islands, Bahamas, Bermuda and Barbados, as well as in the North American Colonies and in British Honduras, whose colonial status was not yet fully recognized $(b)$. In some cases it had existed from the first colonisation, in accordance with the maxim that the English settler carries with him the common law; and the. only political institution which the Crown, without the authority of Parliament, can set up for him is a government based on that of the United Kingdom as it existed in the time after the Restoration. In other cases the Royal prerogative of legislating for a conquered or ceded colony had been used to grant a representative Constitution, and the decision of Lord Mansfield in the famous case of Campbell v. Hall (c) had established the doctrine that such a Constitution once granted could not be revoked by any power short of an Act of Parliament. Financial difficulties, the impossibility of adjusting the relations of the executive to the legislature in Colonies where the legislature is and must be representative of a mere handful of the population, and other causes have combined to reduce the number of Colonies which still possess representative government without responsible Ministries to three only, Barbados, Bermuda, and the Bahamas, while in financial matters, subject to the grant of a civil list by Order in Council, British Guiana has representative government. Jamaica indeed for many years almost enjoyed responsible government $(d)$, for the officers appointed were in close touch with the legislature, whose will was nearly supreme, but the

$\checkmark(b)$ Cf. Journ. Royal Soc. of Arts, Ivi. 343.

(c) 20 St. Tr. 239 ; Shortt \& Doughty, Documents relating to Const. Hist. Canada, 1759-91, pp. 366 seq.

(d) See House of Lords Papers, 1864, xiii. 205. 
weakness of the system was plainly revealed in the rebellion of 1865 , and the legislature next year extinguished voluntarily its authority. In the rest of the West Indies the main cause of alteration was financial trouble, and the natural insistence of the Imperial Government on retaining the complete control over legislation where imperial funds were to be granted. In 1876, Tobago, Grenada, and St. Vincent surrendered their independent legislatures $(e)$, while in the case of the Leeward Islands the process, which began earlier and was accelerated by the federation of the group in $18 \pi 1$, was not completed until 1898, when the financial neods of the group induced the legislatures of Antigua and Dominica to surrender their elective element.

It is significant that even in the case of the Colonies which still remain under representative government some attempt has been made to reconcile the natural opposition of the executive and the legislative powers. In Barbados there has been created, by agreement with the legislature, an executive committee on which sit members of the two houses of the legislature with members of the colonial executive, and which initiates all money votes, prepares the estimates and introduces government business $\left(f^{\prime}\right)$. In the Bahamas and Bermuda the plan is adopted of adding to the ordinary members of the executive council members of the colonial legislature, whose presence in the council enables the government to weigh more easily the real feeling of the legislature on business and facilitates the carrying of governmental measures through the Houses.

In none of these cases, however, can much further development be looked for. Bermuda is still an Imperial fortross, while in the Bahamas and in Barbados the Imperial Govern-

(f) $39 \& 40$ Vict. c. 47.

(f) Parl. P'apers [C. 2645]; Barbados Acts, No. 65 of 1891, No. 9 of 1902 . 
ment is trustee for the comparatively large native population, so that these Colonies will probably always remain examples of imperfect development, unless some circumstance arises to render it necessary to repeal their constitutional freedom. In the North American and the Australian Colonies the advance from this state seems so obvious that we are apt not to extend full recognition to the substantial originality of the proposals contained in Lord Durham's report on the provinces of Upper and Lower Canada in 1838. Representative government had been introduced into the two Canadas in 1791, when they were given Constitutions on much the same general lines. The following fifty years were marked by a long series of conflicts between the governors and their legislatures in which both sides showed want of sympathy and reasonableness, culminating in the abortive Papineau rebellion in Lower Canada and in grave unrest in the Upper Province. It was therefore a bold measure and one showing real political genius to suggest, as the proper mode of reform, a measure which took the general control of colonial affairs definitely and once for all out of the hands. of the Home Government. Lord Durham $(g)$ was, indeed, wrong in many of his recommendations: he completely failed to see, what Lord Dorchester had seen before him, that the French nationality had such a hold on the Province of Quebec that its power could never be shaken, and the union of the two provinces which he recommended was a failure and had to be undone on federation in 1867. But the fundamental soundness of his purely political views is seen in the enduring character of the edifice of responsible government which was reared through him, and in the fact that no single point of his exposition of the fundamental character of responsible government requires alteration to-day after sixty-six years of

(g) His report was reprinted in 1902 by Methuen. Of. Egerton, Canáda, pp. $145-153$. 
aotual experience of its working. In rejecting the proposed solution of the constitutional question by the expedient of an elective executive council-an idea which has analogies in the early history of English Constitutionalism-he wrote: " Every purpose of popular control might be combined with every advantage of vesting the immediate choice of advisers in the Crown, were the colonial Governor to be instructed to secure the co-operation of the Assembly in his policy by entrusting its administration to such men as could command a majority, and if he were given to understand that he need count on no aid from home in any difference with the Assembly that should not directly involve the relations between the mother country and the colony." The Imperial Government deserve all credit for their prompt acceptance of these somewhat revolutionary proposals, and Mr. Poulett Thomson was sent out in 1838 with full instructions for bringing the system into operation. It was expressly laid down that the duty of acting in accordance with the wishes of the Assembly was not incumbent in cases where imperial interests were involved, but that in cases of local interest the Governor should guide himself by their wishes instead of endeavouring to lead them to adopt his policy. It was also provided that a change should be made in the tenure of the chief executive officers to permit of alterations in the holders of these offices to be made "as often as any sufficient motives of public policy might suggest the expediency." The new system received further definition in a series of three resolutions (II) proposed in 1841 by the first Ministry of the Parliament established by the Act of 1840 and agreed to, which asserted the necessity of the Governor auting on the advice of Ministers, the requirement that Ministers should be persons possessed of the confidence of the representatives

(h) Egerton, Canada, pp. 174, 175. 
of the people, and the duty of the provincial administration to use their efforts to secure that the Imperial Government should use its powers in accordance with the wishes of the provincial legislature. The death of Lord Sydenham a few days after the resolutions had been adopted delayed for a time their taking full effect, as his successors, Sir Charles Bagot and Sir Charles Metcalfe, were hardly quite in full sympathy with the idea of self-government, but they received an extension and definition from Lord Elgin under whose government the principles of self-government took on their final form in all essentials (i).

The example of the Canadas was naturally followed without delay by the other Colonies, but it was not until 1848, at the urgent instance of the Secretary of State, that the full measure of self-government was fairly under way in Nova Scotia and New Brunswick, and until 1851 that Prince Edward Island received the benefit of the system. The delay was not due to any reluctance to sanction the adoption of responsible government on the part of Lord Grey, but to the natural obstacles which presented themselves from at once the difficulty of inducing Governors brought up under the old régime to accommodate themselves to the new system and the lack of readiness in an Assembly to fall into the ordinary principles of Parliamentary government. In Nova Scotia, for example, the Secretary of State found that the legislature was not ready to make provision for the treasurer whose post it was desired to abolish and to replace by two political officers, and ultimately he had to instruct the Governor to bow to the decision of the Assembly in the matter $(k)$, a decision which was resented both by some of

(i) See Earl Grey, Colonial Policy, i. 205; Walrond, Letters of Lord Elgin, pp. 40 seq. ; Egerton, Canada, pp. 191 seq.

(k) House of Cúmmons Papers, 1847-8, xlii. 56 seq.; of. Egerton, op. cit. pp. 186-190; Houston, Const. Documents of Canada. 
the residents in the province and by the opposition in the Imperial Parliament. In the case of Newfoundlund, there was still longer delay in giving way to the wishes of the people, and at first the Imperial Government could not see their way, in view of the treaties with the Uuited States and France affecting the colony, to sanction the extension to the colony of the same form of government as in the maritime provinces and Canada. But at last they yielded in view of the fact that the financial management of the colony was most unsatisfactory, and that the grant of self-governuent promised to lessen the difticulties of the situation; and in 185.5 the Governor was authorized to adopt the system of ministerial responsibility in its full form, while later an assurance was given by $\mathrm{Mr}$. Labouchere that the colouy would be consulted before any further treaty arrangements were made concerning it $(l)$.

The same year saw the completion of the grant of selfgovernment to the four Australian Colonies. It had been foreshadowed in the Imperial Act of 1850 , which empowered the legislatures already in existence, which were representative in character since 1842, to alter their Constitution by erecting two Houses in place of one, and the power was used by all the Colonies save Western Australia, which was still a mere handful of settlers far removed both in space and in sentiments from the rest of Australia. There was a good deal of discussion in the Colonies and in the mother country on the precise terms to be given the Colonies, and in the Constitutional Bills of New South Wales and Victoria it was sought to establish a legislative distinction between the matters which were imperial and those which were of purely local interest. It was, in fact, decided by the local legislatures to restrict the power of disallowance of Acts to those of imperial interest, and imperial interests were

(l) Prowse, Hist. of Yeufoundland, pp. $460^{\circ}$ seg. 
restricted to allegiance, naturalization, treaties, political intercourse with foreign Governments, the discipline of the troops and defence, to which list Victoria added divorce, while Tasmania wished to be able to dismiss the Governor and to define the imperial prerogative. This proposal the Imperial Government declined to accept, and indeed it would have been foolish in the extreme thus to limit beforehand imperial interests. But generally the colonial legislatures got their own way, and their Acts were aecepted and allowed with-in the case of New South Wales and Victoriacomparatively slight alterations. At the same time, the Colonies were relieved from the operation of the land Acts in force, and were entitled to control their vast areas of land $(m)$.

In New Zealand, the Act of $1852(n)$ gave representative government, but as no mention of responsible government was made in the Act, the colonial legislature proceeded to petition for the grant of that form of government by the alteration of the Constitution. The Secretary of State, however, pointed out that all that was wanted was not an alteration of the Constitution but the passing of a pension Act to secure pensions on abolition of office to those officials whose posts would be made political by associating them with the confidence of the legislature, and on this being done the Governor was instructed that the colony should enjoy in the fullest measure the doctrine of responsible government $(0)$.

Accordingly, a Ministry was formed in 1856, and the Governor laid down in a minute, which was approved by the Secretary of State, the doctrines of self-government in the propositions that in local affairs the Governor would act as

(m) See 18 \& 19 Vict. c. 54 (New South Wales), c. 55 (Victoria); Tasmanian Act (17\& 18 Vict. No. 17); South Australiau Act (No. 2 of 1855-6); and Jenks, Hist. of the Australasian Colonies, 1896 ; and, for Tasmania, Acts, fer. of the Legislative Council, 1879, pp. 54-56.

(n) $15 \& 16$ Vict. c. 72.

(o) House of Commons Papers, 1860, xlvi. 169. 
a constitutional monarch, but would be free to act on his own responsibility in matters of imperial interest, but would consult Ministers even in those cases, and refer their views to the Secretary of State. $\mathrm{He}$ added that in appointments he would expect an assurance in each case that the person recommended was a fit and proper person for the post $(p)$.

In 1859 the newly-created colony of Queensland received, immediately on its creation, responsible government, which the Governor interpreted in terms very similar to those used by the Governor of New Zealand in 1856. $\mathrm{H}_{0}$ also placed great stress on the Governor's right to secure that appointments were not bestowed on persons unworthy of office, and in this view he had the support of his Ministers $(q)$.

The next grant of responsible government was offered in 1869 to the Cape of Good Hope $(r)$. The correspondence arose out of the military question of the defence of the colony against the Kaffirs. The Imperial Government, as early as 1867, intimated their expectation that the colony would assume some of the burden of the cost of its defence, while the Governor represented that the colony was too poor to do so, though it fully recognized that it ought so to act if and when funds were available. The Governor was himself much opposed to self-government, and it is decidedly interesting to note that he prophesied without doubt that the inevitable result of self-government would be the secession of the Colonies. $\mathrm{He}_{\mathrm{c}}$ considered such secession ineritable in the case of Australia, New Zealand, and North America, and did not disapprove the grant of self-government there; but he thought that South Africa was not ripe for setting up for itself, and considered that it was essential in the interests of the natives, and, indeed, of all concerned, to maintain the

(p) Ibid. pp. 228, 229, 481.

(q) Ibid. 1861, xl. 607 seq.

(v) Parl. Papers [C. 459], [C. 508], [C. 732]. 
existing arrangements. He recognized, however, the need of restoring harmony to the relations of the Fxecutive and the legislature, and he accordingly obtained the permission of the Secretary of State-who, however, favoured responsible government-to put before the constituencies a proposal for the amalgamation into one of the two Houses of the legislature. The plan was, of course, intended to diminish the difficulty of dealing with two bodies, both elective and apt both to be in opposition, but, as the Secretary of State pointed out, the plan was hardly likely substantially to lessen the difficulties of the executive Government. At any rate, the idea never was tried, as the Assembly threw out the Bill, and the last chance of the reversion of the Cape to a Crown Colony disappeared. Sir Philip Wodehouse, who held these pessimistic views as to the possibility of responsible government in the Colonies, was succeeded by Sir Henry Barkly, who was inclined to favour responsible government from bis experience of it in Australia, and he received a clear intimation from the Secretary of State that the better course for the colony to adopt was to accept the offer of responsible government, while it was stated that there was little probability of the Imperial Government consenting to the annexation of the goldfields until the colony accepted responsible government. This view must be regarded as having been inevitable, inasmuch as an executive Government too weak to manage satisfactorily the affairs of the Cape could not in reason be expected to take upon itself the responsibility for the control of the new and distant territories proposed to be annexed. On the other hand, the situation was seriously complicated by the fact that the residents in the eastern part of the colony were not anxious for the grant of responsible government, which would result in their being ruled from Capetown and the west, and in consequence the Bill to establish responsible government was rejected in the Upper 
House, in 1871, by twelve votes to nine, there being in the majority eight eastern members, and in the minority in favour of the Bill only two. But the check was only temporary, and, indeed, in view of the complicated relations with the Orange Free State and the Transvaal over the new territories, which the Imperial Government were desirous of accepting for the colony, it was essential for the maintenance of the British position that the Government should be supported by the weight of a responsible Ministry. This view accordingly prevailed when the Bill was re-introduced in 1872 , and it was passed by the two Houses, though there still were some discontented persons who protested against the domination of the west over the east of the colony. Luckily, they were not in a position to make their views effective, and the Imperial Government were not willing to override the colonial legislature in the matter. Whatever the disadvantages of the position, the colony, as divided, would have been far too weak for any effective part to have been taken by it in South African politics, and the results might have been the loss of the British hegemony in South Africa.

In Natal $(s)$ the grant of self-government was longer delayed. There were a good many reasons for this fact. The population was not only small but the country was surrounded by ferce native tribes, which could only be kept at a distance by the exertions of the Imperial forces; and it was established by the discussions of 1869 in the Cape that purely native risings must be subdued by the use of the local forces in any ease where self-government was granted. As the native policy of Natal must obviously re-act upon all the relations of the Crown to the native races in South Africa, the Crown could not well entrust the conduct of affairs in Natal to a Ministry whose actions it could in no way super-

(s) Parl. Papers [C. 6487] and [C. 7013]. 
vise effectively. But equally naturally the white population was anxious to obtain the same status as the population in the Cape, and their desire became more possible of fulfilment when the defeat of the Zulus left the danger from the natives much less serious. But it was not until 1892 that the colonial legislature, in which the official members were instructed not to vote against the proposal, was able to produce a Bill in which the Imperial Government could concur. This result was reached after discussion between the Secretary of State and Sir John Robinson and Mr. Sutton, who were sent to England as the representatives of the responsible Government party in the legislature. The principal points in which the Bill was altered to meet the views of the Colonial Secretary are worth enumeration. In the first place, the legislature. was to consist of two chambers instead of one chamber as desired by the colony, the Secretary of State not being prepared to adopt a form of legislature unknown in any selfgoverning colony. Secondly, the legislature placed at the uncontrolled disposal of the Governor 10,010l. a year, to be used for the welfare of the natives; the colonial draft granted $20, \mathrm{COOl}$. but retained the right of appropriation of the items. In the third place, the power of the Governor, as supreme chief over the natives, was to be exercised by him on his own responsibility, instead of being delegated to the Governor in council, as proposed by the colonial Bill. The delegates protested against some of the alterations, especially the attempt to place the native policy in the hands of the Governor, but they gladly accepted the altered Bill as a whole, and it was sent out by Lord Knutsford for the acceptance of the people and legislature. But the election held was unfavourable to responsible government by fourteen votes to ten, and the Legislative Council declined to proceed with the Bill. But election petitions were promptly brought against four of the anti-responsible government party and they were unseated, 
while the new elections resulted in the return of four members in favour of responsible government. The Bill then was re-introduced into the Council, and passed as Act No. 14 of 1893, receiving the sanction of the Imperial Government.

Western Australia $(t)$ had received responsible government in the year 1890. In 1870 it was granted representative government, but for some years after that its future seemed to lie on lines remote from those of the rest of Australia. By the middle of the eighties, however, the influx of Australians from the east, and the growth of a colonial population, led to a development of the demand for self-government, and the legislature began to frame projects for the alteration of the Constitution. The Imperial Government felt some difficulty in meeting their wishes, owing to the vast size of the territories of the colony, the divergence of interests between the several parts, the responsibility involved in the maintenance of order on the gollfields, and the comparatively large aboriginal population, the protection of which was found exceedingly difficult, even under a Crown executive. Various schemes were mooted to meet these objections, and plans for the division of the colony were considered. But finally the Imperial Government decided to postpone consideration of the position as to division, and the local legislature passed an Act, which was confirmed by an Imperial Act of 1890 , under which the Government of Western Australia was re-organized as a responsible Government. The legislature was divided into two Houses-the upper to be nominated in the first instance, but to become elective when the colony should have a population of 60,000 people, exclusive of aborigines, or six years should have passed since the summoning of the first nominee council. As a matter of fact, the new provision was brought into force by an Act of $189 \mathrm{t}$, as a result of the increase in the population of the colony.

(t) Parl. Papers [C. 5743], [C. 5752], [C. 5919], [C. 5919 I.]. 
The cases of the Transvaal and the Orange River Colonies (u) were in many respects unique. Under the terms of peace by which the war was terminated, the Colonies were promised, in due course, representative institutions ; and in the negotiations leading up to the surrender it was expressly stated that the Imperial Government would, as soon as possible, give them a Constitution on the model of that of the Cape. In accordance with this undertaking, the Imperial Government framed a Constitution, embodied in Letters Patent, under which the Transvaal received representative government, with a single chamber and a certain number of nominees added to the elective members. This Constitution was received with some criticism in the colony, because of the obvious difficulty of the conduct of the Government by an executive which was without Parliamentary experience, and, on the advent of the Liberal Government to office in 1905, the decision was taken to create at once responsible government in both the colonies. A commission, of which the chairman was Sir West Ridgeway, proceeded to South Africa to make inquiries as to the possible basis of the Constitution as regards electoral arrangements, and, as a result, there were issued in the end of 1906 Letters Patent, creating responsible government for the Transvaal, followed in 1907 by similar Letters Patent for the Orange River Colony. By these instruments the Colonies were at once accorded full selfgovernment, subject only to reservations as to native affairs, in which the Governor was given the position of supreme or paramount chief, independently of his Ministers, as to the employment of labour under servile conditions, and as to the management for five years of the land settlement policy of the colony. The latter reservation was due to the fact that, under Crown Colony government, a considerable number of

(u) Parl. Papers [Cd. 2400], [Cd. 2479], [Cd. 2823], [Cd. 3250], for Transvaal; [Cd. 3526] for Orange River Colony. 
settlers had been introduced, and it was thought that the policy might not be regarded with favour by the new Governments, and that the settlers might not receive the very considerate treatment essential to their survival in the difficult circumstances of South Africa. Power was, however, given to the colonial Governments at any time before the expiration of the period to take over the full control of the matters within the management of the board appointed to look after the land settlers, on an agreement being arrived at with the board, and approved by the Governor and Secretary of State.

The same policy of extending the advantages of selfgovernment to all territories where the population is white has been followed by the Canadian Government in its dealings with the vast territories in the north-west entrusted to the care of the Dominion by the Imperial Government $(x)$. In 1870 the province of Manitoba was created with full selfgovernment, and in 1871 the union of British Columbia with the Dominion was combined with the establishment of the system of ministerial responsibility. The latest additions to the list of provinces were made in 1905 , when the great provinces of Alberta and Saskatchewan were carved out of the North-Western Territories and erected into provinces with almost the same privileges and rights as those enjoyed by the older provinces, which had an existence independent of the Canadian Parliament. These new provinces are limited in their resources in some respects, but they enjoy to the fullest degree the benefits of responsible government.

(x) See Munro, Const. of Canada, pp. 26 seq. ; and, for the new provinces, the Canadian Acts (4\& 5 Edw. VII. c. 3 and c. 42): Revised Statutes, 1906, vol. iv.; and ef. Lefroy, Legislative Power in Cunada, pp. 705-709. 


\section{CHAPTER II.}

THE LEGAL BASIS OF THE DOMINION CONSTITUTIONS.

IN the preceding chapter we have traced the circumstances under which the several Dominions successively obtained the grant of responsible government, and we propose now to examine the legal basis in which in each case the grant rests. While there are in point of fact no less than three ways in which the status of representative government has been obtained, by imperial legislation, by a colonial Act, and by Letters Patent issued under the royal prerogative, it will be found that in all cases the grant of responsible government rests on nothing more formal, in the ultimate analysis, than instructions from the Secretary of State to the Governor, though in differing degrees the Constitutions recognize the system of ministerial government.

There is no hint in the Imperial Act of 1840 , whish reorganised the province of Canada, that it was intended vitally to alter the mode of government hitherto in force. The actual introduction of responsible government consisted in the instructions sent to the Governor-General to take as his advisers those who could command a majority in the legislature, a principle which in a few years developed into the full doctrine of a Parliamentary executive. Similar instructions were sent to the Lieutenant-Governors of Nova Scotia, New Brunswick and Prince Edward Island, and by 1848-1849 the system of responsible government may fairly be said to have been established in Canada. It is clearly assumed as existing throughout the British North America Act, 1867, 
by whioh Canada was federated, but it is nowhere expressly enacted that the members of the Government must have seats in the legislature, and in point of fact the Privy Council for the Dominion is composed of many persons who have long ceased to hold any place in Parliament. But by custom Ministers are as much required to have seats in Parliament as Ministers in the United Kingdom. The same principle was applied when British Columbia received responsible government on its union with the Dominion in 1871, when Manitoba was given the same privilege in 1870 , and on the recent oreation in 1905 of the two provinces of Alberta and Saskatchewan $(a)$. Generally speaking, it may be said that in Canada the principle of self-government rests on the conventions of the Constitutions, whether provincial or federal, and not upon express enactment.

The same rule applies to Newfoundland. In that colony the grant of responsible government was made in 1855 by despatch, in effect instructing the Governor to adopt the same practice in choosing the members of the newly-created $(b)$ Executive Council as in Canada. There is no provision in any local Act that the executive councillors shall hold seats in the legislature, though, of course, in point of fact they as a rule do so. Exceptions occasionally occur, as in 1908, when the Minister of Justice, Mr. Kent, was for several months not a member of Parliament $(c)$.

Similar in principle are the Constitutions of the Transvaal

(a) For the Acts, see Canadian Reviscd Statutes, vol. iv. They do not, in any case, formally confer responsible government.

(b) An Executive Connoil was constituted by Letters Patent in that year, but this might have been a Crown Colony executive for all that the document contains.

(c) So, in 1907, in Queensland, Mr. Airey was for a time without a seat in Parliament; cases in Canada, in Ontario in 1898, and in British Columbia in 1900 are given in Canada Sess. Papers, 1900, No. 174 ; but great exception was taken in the last case, which was one of the causes of the LieutenantGovernor's dismissal. 
and the Orange River Colony, granted on 6th December, 1906 , and 5th June, 1907, respectively $(d)$, but in them formal notice is taken of the existence of Ministers with seats in the legislature. 'The Constitutions depend on the Letters Patent declaring the composition of the legislature and executive issued in both cases under the royal prerogative of legislating for conquered Colonies. In this respect the position differs fundamentally from that in Newfoundland, where the existence of a representative legislature depends on Letters Patent of 1832, which, precisely speaking, are based on the right of the Crown to establish in a settled colony a Constitution on the basis of the English Constitution before the rise of responsible government proper, while the existence of ministerial government rests on nothing more than usage, and the instructions to the Governor and the creation of an Executive Council in 1855. The Governor might in theory at least be instructed to revert to the practice in force before 185.5, and to choose his Ministers at will without regard to Parliament, and it is possible to do this even in the case of the Transvaal and Orange River Colony, since Ministers are not legally bound to have seats in the legislatures.

The other two South African Dominions owe their responsible government to local Acts. The Cape obtained representative government by a local Ordinance of 1852 , which the then existing Legislative Council was specially empowered to enact by Letters Patent of 1850 , and in 1872 the legislature created under the Ordinance, which was confirmed by an Imperial Order in Council of 1853, provided by the Constitution Ordinance Amendment Act (No. 1) of 187\%, that five specified offices could (not "must") be held by members of the Legislative Council or House of Assembly without vacating their seats, and provided pensions for the

(d) Parl. Pupers [Cd. 3250], Transvaal; [Cd. 3256], Orange River Colony. 
officers holding the posts " in the event of retirement on political grounds." It is therefore only by constitutional custom, as in Canada and Newfoundland, that Ministers are regularly members of Parliament. In the case of Natal, which received representative government in 1856, the Act (No. 14) of 1893, establishing responsible government, is much more explicit. It expressly lays down that every Minister shall be, or shall within four months become, a member of the Legislative Council or House of Assembly, while to prevent the misuse of the power of appointing Ministers members of the Council, which is a nominated body, it is provided that not more than two Ministers can be members of the Council.

The case of Natal is worth considering more in detail, as a specimen of the limited expression given even in a law expressly intended to introduce responsible government to that principle. The framers of the Bill were anxious to make it contain a clear exposition of the character of the government which it was desired to establish, and one clause of the reserved Bill, No. 1 of 1892 , which did not receive the Royal Assent, reads :- "The words 'Governor in Council' in this Act or any other Act or law appearing shall be deemed to mean the Governor acting with the advice of the Ministers, and such Ministers shall constitute the Executive Council." It was also provided in the Bill, as in the later Act of 1893, that Ministers must have or obtain seats in Parliament, and, had the Bill been accepted by the Imperial Government, the Constitution would have expressly provided for the constitution of an Executive Council composed of Ministers liable to retire or be dismissed on political grounds. But the Secretary of State was not prepared to accept the plan of defining in an Act the Executive Council, and in the result the clause was by agreement struck out. Thus it remains in strict law open to the Governor to appoint his 
Executive Council in any way he likes, ignoring, if he saw fit, Parliament altogether, though he could not put his nominees in charge of the important posts in the colony reserved for Ministers as members of Parliament, and business could not be carried on.

Precisely the same remark applies to the cases of the Transvaal and the Orange River Colony, where again the Executive Council is constituted only by the Letters Patent creating the office of Governor. Such Letters Patent indeed are issued not in virtue of the prerogative of legislation for a conquered colony, but by the wider prerogative of constituting the executive Government for a colony, which belongs to the Crown wherever it has not been expressly by law taken away. It is, however, significant that the Letters Patent do expressly say that the Executive Council shall "consist of" such persons being Ministers or other persons as the Grovernor shall from time to time appoint under the public seal of the colony." Thus the recognition of the presence of Ministers on the Council becomes more marked, though there is no legal obligation on the Governor to appoint Ministers either alone or at all to the Council, and in form the choice is left entirely open to him. In the case of Canada the Executive Councils of the Dominion and the provinces alike are mentioned in the British North America Act, 1867, but there is no hint in law that they must be composed of Ministers, and the provinces have always left the appointment by law in the hands of the Lieutenant-Governors $(e)$, and the same remark applies to the Councils of the Australian States, Newfoundland and New Zealand $(f)$, in all of which the appointment of the Executive Council remains undefined by law, even when Ministers are referred to in the Constitution Acts.

In the case of the Australian States the existence of

(e) E.g., Quebec Act, No. 7 of 1901 ; Ontario Act, No. 6 of 1908, \&c.

(f) Cf. Const, and Government of New Zealand, 1896, p. 179, n. 2. 
responsible government may be said to depend in part on imperial Acts. No Colonies have been the subject of so much imperial legislation as those in Australia. The cause is probably to be found in the history of the settlements. It was clearly necessary to exercise legislative powers over the rapidly increasing number of free settlers shortly after the founding of the Colonies ; but the presence of many desperate characters rendered it rather difficult to carry out the simple plan, and the only procedure possible in a settled colony, viz., that of creating a representative legislature by the prerogative. Therefore recourse had to be had to imperial legislation, under which a full measure of representative government was only granted in 1842 and $1850(g)$. The Act of the year 1850 empowered the Colonies to alter the Constitutions provisionally settled by that Act, and, in fact, in 1855 both Victoria and New South Wales by local Acts, formally confirmed and modified by imperial legislation, provided themselves with responsible government. Similar local Acts, which it was not considered necessary to confirm by imperial legislation, were passed by Tasmania, 17 \& 18 Vict. c. 17, and by South Australia, No. ' 2 of $1855-1856$. None of these Acts expressly provide for a Parliamentary executive, though references are made in them all in connection with the composition of the executive Government to pensions for officers liable to retire on political grounds, and, except in the Tasmanian Act, the appointment of all officers, save those liable to retire on political grounds, is rested in the Governor in Council, as is also the case in the Commonwealth, Natal, the Transval and the Orange River Colony Constitutions. Both representative and responsible government were simultaneously given to Queensland on its separation from New South Wales in 1859 by Letters Patent made in virtue of 
one imperial Act $(h)$ and expressly confirmed by another $(i)$. In the case of South Australia and Victoria it is expressly provided that certain Ministers shall be members of the legislature, though in neither case is there anything to prevent the appointment as a member of the Executive Council of a person not in Parliament. In the Western Australia Constitution Act of $1890(j)$, an imperial Act confirming, with modifications, a local Act passed by the existing representative legislature in 1889 , provision is made for the existence of five principal executive offices, which may be held along with seats in the Legislative Council or Legislative Assembly, and one of which must be held by a legislative councillor. Reference is also made to pensions for officers holding, at the date of the Act coming into force, posts liable to be vacated on political grounds, but even the later legislation of the Parliament in 1893 and 1899, which has increased to six the number of political offices, does not prevent the appointment as a member of the Executive Council of a Minister without seat in the Parliament, however unconstitutional such a course would be.

The State Constitutions are indeed all somewhat antiquated in date, and it might be expected that in the Commonwealth Constitution further recognition of modern practice would be found. But even there the provisions do not go beyond requiring that no Minister shall hold office for more than three months unless he shall become a member of the Senate or House of Representatives. The Executive Council is, moreover, not limited in number, though it must include the Ministers-seven in number-in charge of departments, whose number cannot be increased without the

(h) 18 \& 19 Vict. c. 54 . It ignores the executive.

(i) 24 \& 25 Vict. c. 44, s. 3.

(j) 53 \& 54 Vict. c. 26. Cf. for this, Jenks, Hist. of the Australasian Colonies, 1896; Harrison Moore, Commonwealth of Australia, Chap. I. 
approval of Parliament. But there are no legal rules providing for retirement, or requiring that Ministers should have a majority in the Houses. Ministers, strictly speaking, are the servants of the Governor-General alone, who in theory can appoint any persons he pleases, provided that they become, or are, members of Parliament, and who can add non-Ministers to the Executive Council (k).

In contrast with the Commonwealth of Australia is the Dominion of New Zealand. The Constitution Act of 1852, passed by the Imperial Parliament, never mentions, from beginning to end, the jdea of responsible government; and, after the meeting of the first Parliament, there ensued a deadlock, the existing executive officers keeping their seats without reference to the wishes of the Parliamentary majority. In response to appeals, the Secretary of State pointed out that no fresh legislation was required; that it was only necessary for the Parliament to make provision for pensions to the retiring officers, and that the Governor could then proceed to choose his advisers from among those who possessed the confidence of Parliament. On this basis the self-government of New Zealand still rests. Strictly speaking, as in Canada and Newfoundland, it rests only on constitutional practice arising out of instructions given to former Governors (l).

It will be seen from this summary that the legal basis of responsible government is, as a rule, extremely-slight, and that it rests mainly, or entirely in some cases, on constitutional practice. But, as in the case of the United King-

(k) Cf. Harrison Moore, Commonicealth of Australia, p. 212.

(l) The Executive Council could still contain non-Ministers, but the Instructions contemplate that it will consist of responsible Ministers. Cf. Ministers' Salaries and Allowances Act, 188 $\mathbf{i}$; Const. and Government of New Zealand, 1896, pp. 171, 172, 183, 184. The Attorney-General need not be a member of Parliament: Act No. 22 of 1908. 
dom, the system rests secure on the fact that, if not followed, the result would soon be administrative chaos. In the first place, it should be noted that no Ministry can establish itself in power and maintain itself there against the will of the people unless they have the support of the Governor of the colony. In every case, without exception, the appointment of Ministers is at pleasure, and they can be dismissed at will by the Governor. If, however, the Governor were to desire to keep in office against the popular will, as expressed in Parliament, a body of unpopular Ministers, the Parliament would decline to grant supply, with the result of -the-almost immediate paralysis of the public sêrvice, unless Ministers were prepared to advise the Governor to take the responsibility of issuing money without the sanction of Parliament. Under exceptional circumstanees this might be done for a short time, but, of course, only in the expectation that the Parliament did not represent the real feeling of the people.

In the long run within the colony itself the will of the people, or rather of the voters, must prevail, unless the Imperial Government should intervene. Such intervention has-only once been seriously considered of recent years during the war in South Africa, when the grave difficulties of carrying on responsible government in the Cape, and the impossibility of calling the Parliament together in accordance with the law of the Constitution, suggested the temporary suspension of the Constitution $(m)$. The means contemplated was necessarily the highest expression of the imperial legislative power, an Act of the Parliament of the United Kingdom, which alone could have made provision for the gorernment of the Cape during the suspension of the

(m) Parl. Papers [Cd. 1162]. There were various unofficial suggestions of suspension of the Newfoundland Constitution in 1895, during the financial crisis in the Colony, in return for imperial assistance; but nothing was done. Cf. Parl. Papers, H. C. 104, 1895, and [C. 7686]. 
LEGAL BASIS OF' THE DOMINION CONSTITUTIONS. 27

Constitution, if it was desired to abolish for the time being the legislature. A local Act, had such legislation been practicable, would have been sufficient to alter the Constitution, but not to the extent of abolishing it, for the power of legislation given to a colony, as will be seen below, does not extend to a complete alteration of its fundamental characteristics. 


\section{CHAPTER III.}

\section{THE GOVERNOR.}

A CERTain amount of confusion as regards the actual functions and powers of a colonial Governor appears to have been caused by the well-known cases in the Courts $(a)$, which have decided that a colonial Governor is not a Viceroy. This statement is undoubtedly true, but its effect is not to limit seriously the powers of the Governor. It means that he-is not invested with the whole of the royal prerogative, but only with such part as is delegated to him by the instruments constituting his office. These instruments consist, since 1875, of permanent Letters Patent under the Great Seal of the United Kingdom constituting the office of Governor, and conferring upon him executive power and a share in legislation, of Instructions under the sign manual and the signet directing him how to exercise the functions delegated in the Letters Patent, and of a Commission appointing the officer in question to act according to the powers ascribed in the Letters Patent and Instructions. Further Instructions are given by the Secretary of State, either formally in the name of His Majesty, or, less formally, in virtue of the power vested in the Secretary of State, as the mouthpiece of the King.

The Letters Patent make no attempt to set the Governor up as a representative, in a complete sense, of His Majesty,

(a) Cameron v. Kyte, 3 Knapp, 332 ; Musgrave v. Pulido, L. R. 5 App. Cas. 102, at p. 111 ; Hill v. Bigge, 3 Moo. P. C. 476. 
but they delegate to him in the fullest manner the general executive power of the Crown in the colony by directing him to perform all the acts appertaining to the post of Governor in the colony. This does, indeed, seem rather a curious way of constituting a post by reference to the duties actually appertaining to it, but it is merely in keeping with the general principle of all instruments relating to the executive government both in England and the Colonies. The established practice is assumed, and anything laid down becomes only intelligible in the light of the practice as known ab extra. In some Acts, however, the fact that the executive power of the colony is vested in the Crown and in the Governor-General, as the representative of the Crown, is expressly recognized, as in the cases of the Constitutions of the Commonwealth of Australia (b) and of Canada (c). But there is not the slightest need for these provisions, and in the very latest instruments of government issued for responsible Government Colonies-those issued for the Transvaal and the Orange River Colony-there is no enactment to this effect; but the Letters Patent constituting the office of Governor assume that the duties of a Governor are things already known and understood. Indeed, the only result of the inclusion of the clause in the Australian Constitution defining the duties of the Governor-General has been to raise the doubt expressed by Sir John Quick, Mr. Garran, and Mr. Harrison Moore (d), in their expositions of the Constitution as to whether the Letters Patent are valid, the post having been constituted by the Act.

(b) Sect. 61 of Constitution.

(c) Sect. 9 of British North America Act, 1867. The theory that the Governor is a Viceroy is curiously developed by the Chief Justice of Victoria in Toy v. Musgrove, 14 V. L. R. 349, on which see Lefroy, Legislative Poncer in Canada, pp. 115-120; and ef. the resolution of the Victorian Legislative Assembly in 1869 (ibid. p. 120, n. 1), and 4 C. L. R. 1126.

(d) Commonwealth of Australia, p. 229. 
This view seems, however, to rest on a false basis, and to be due to a misunderstanding of the real nature of the Letters Patent. The fact is that the Letters Patent issued to constitute the office of Governor are not exercises of any legislative power on the part of the Crown, but are a signification of the pleasure of the Crown as to the mode of conducting the executive government of the colony. The power may be restricted by law binding the Crown by express words, but such a law would hardly ever be allowed, and if no Letters Patent had been issued for the Commonwealth, there would have arisen a series of difficult questions, such as the right of the Governor-General to grant pardons $(e)$, the succession to the Governor-General in the case of his absence, the right of the Governor-General to appoint deputies $(f)$. In all these instances the doubt would have arisen how far these powers were included in the executive government of the Commonwealth without a special delegation from the Crown, and, indeed, the necessity of such Letters Patent is recognized in the clearest way possible in the second clause of the Constitution, where it is said that the Governor-General shall have and may exercise in the Commonwealth such powers and functions of the Crown as may be assigned to him by the Crown. Moreover, in all the Colonies, save Australia and Canada, the very existence of an Executive Council is found only in the Letters Patent and Instructions.

Once it is realised that the powers assigned to the Governor cover all the ordinary executive authority of the Crown, it becomes quite unnecessary to accept any doctrine of a special reserve power in the Governor. The idea seems, indeed, to be due to the terms of the cases on the question of the Governor having viceregal powers above alluded to, on which undue stress should seem to have been laid. It is no doubt true, as

(e) Cf. 23 Canada S. C. R. 468, 469.

(f) Cf. sect. 126, which requires a delegation. 
pointed out by Mr. Todd (g), to whom the authorship of the conception of reserve power is to be ascribed, that the colonial Governor has a delegation of so much of the authority of the Crown as may be necessary for the purpose of administering the government of the colony, over which he is placed by the Crown, and that the office of Governor is as much a constituent of the Coustitution in every colony as is that of either of the other branches of the colonial legislature. But this merely means that he is the head and source of the executive government. It does not mean that he has any special power of disregarding the law, and the doctrine leads Sir Henry Jenkyns $(h)$ into somewhat inaccurate language when he writes that " there can be no doubt that a Governor will always be held to have had all the power necessary for meeting any emergency which may have required him to take immediate action for the safety of the colony. If he acts in good faith, and, having regard to the circumstances, reasonably, he will be held harmless." If this means that his actions in emergencies are justified if they are done in good faith and reasonable, it goes a good deal too far. They must also be lawful, for the power to act is based on the same principle as the power of any executive officer at home. In both cases, as shown by the classical cases of $R$. v. Pinney (i) and Phillips v. Eyre (k), the Governor or other officer is entitled to repress open disorder or rebellion by force, but there are many emergencies in which he is helpless, unless he is prepared to violate the law and trust to an Act of Indemnity. As a matter of fact, the right of suppressing armed revolt is so uncertain in extent, however undonbted in principle, and the view of a Court, after the excitement of

(g) Parl. Govt., ed. 2, p. 36.

(h) British Rule and Jursdiction beyond the Seas, p. 103.

(i) 3 B. \& Ad. 958.

(k) L. R. 6 Q. B. 1. 
the immediate crisis is over, so unlikely to cover all the acts done under the operation of martial law, that Governors are habitually, like all other officers, protected by Acts of Indemnity, as was the case in Eyre's case.

It remains now to see what are the real limits imposed on the power of a colonial Governor. In the first place, it is certain that he is not entitled to grant titles of honour, and his discretion in granting precedence is fettered by authoritative instructions which he is bound to obey. It is not, therefore, within the power of a colonial Governor to approve the issue of any decorations, even for services rendered within the colony; if it purports in any way to be an award from the Crown.

In the second place, the Governor has no delegation of the coinage prerogative, and, so far as that prerogative is exercised independently of statute, it is exercised directly by the King by Order in Council and proclamation (l).

In the third place, the outcome of the long disputes in Canada with regard to the power of pardon seems to be correctly summed up in the decision of the Chief Justice of the Dominion in the case of Att.-Gen. for Canada v. Att.Gen. for Ontario $(m)$, in the view that, save by statute, the Governor has no power of pardon unless it is specially delegated to him by his Letters Patent and Instructions. On the other hand, it must be remembered that in all cases the power is delegated, and is one in some respects essential for the due carrying of a colonial Government, so that; if by error it were ever not given in the Letters Patent, it might be assumed to have been omitted by inadvertence and

(l) Chalmers, Colonial Currency, Chap. II.

(m) 23 Canada S. C. R. 458; contra Blake, The Executive Power Case (Toronto, 1892) ; but cf. Lefroy, Legislative Power in Canada, pp. 113 seq., $130 \mathrm{seq}$. 
regarded as included in the powers normally and properly deemed to belong to a colonial Governor virtute officii $(n)$.

In the fourth place, the Governor is not exempt from suit. This is certainly a most important difference between the Governor and the Crown, and distinguishes a colonial Governor from the Lord-Lieutenant of Ireland. Efforts have, indeed, been made as by Mr. Tarring $(o)$ to diminish the difference between the position of a Governor and that of the Lord-Lieutenant, but the effort can hardly be called successful. The essential part of the distinction is that under the law as it now stands any suit against the Lord-Lieutenant is dismissed on the application of the Attorney-General of Ireland without enquiry into the merits of the case: his Excellency's acts cannot, during his tenure of office, be examined judicially $(p)$. No such exemption can be pleaded in the case of the Governor. He can be sued in the Courts of the colony for private debts as if he were not Governor $(q)$ : the modern state of the law in cases of action for debt is such that there is no chance of the serions discussion of the question, once debated, whether or not he could be arrested on a capias if judgment went against him $(r)$. Further, he must answer in a Court for all actions in which he is accused of breach of civil rights of the people of the colony. In the case of Musgrave v. Pulido $(s)$, it was held on appeal in the Privy Council that the Governor was liable for the damages awarded

(n) But see Harrison Moore, Commoncealth of Alcstralia, pp. 218-2:0. It seems to me clear that the Canadian Lieutenant-Governors possessed, virtute officii, all necessary Provincial prerogatives; they were neither Viceroys nor mere creatures of Provineial Acts.

(o) Lawo relating 10 the Colonies, ed. 3, Chap. II.

(p) Tandy v. Earl of Westmoreland, 27 St. Tr. 1246; Luby v. Lord Wodehouse, 17 Ir. C. L. R. 618 ; Sullivan v. Spencer, 6 Ir. C. L. R. 176. This is, I take it, the real result of these cases.

(q) Hill v. Bigge, 3 Moo. P. C. C. 465.

(r) Ibid. p. 476.

(s) L. R. 5 App. Cas. 102.

K. 
by a Court in Jamaica in respect of the detention on insufficient grounds of the "Florence," a vessel suspected of committing a breach of neutrality. In Phillips v. Eyre $(t)$, an action was brought in England against the ex-Governor of Jamaica for false arrest and imprisonment in Jamaica, and the reply, which was held good, was an act of indemnity passed by the legislature of the colony, but it was admitted, on the strength of previous cases, such as that of Fabrigas $\mathbf{v}$. Mostyn (u), that the action was competent and conld not be answered by any allegation of authority to act illegally vested in the Governor. The difference between the Crown and a Governor in this respect is obvious and natural. The doctrine of the irresponsibility of the Crown is only possible, because the maxim that the King can do no wrong leaves his servants, who have actually carried out his illegal commands, without protection: it is impossible to plead the King's commands when ex hypothesi no such command can have been issued by the King. At the time when the doctrine of the responsibility of the Governor grew up, he was in fact the sole director of the policy of the colonial government, and his legal position was fixed before the development of responsible government created a position in which the responsibility for action might more naturally have been placed upon Ministers. But the placing of such responsibility on Ministers would only have been consistent with complete ministerial control of policy, and Ministers cannot even now be said to have that control $(x)$.

This legal responsibility adds considerably to the perplexity of the position of a colonial Governor in cases where his Ministers desire him to take action of a doubtful character as

(t) L. R. 4 Q. B. 225 ; 6 Q. B. 1.

(u) 20 St. Tr. 81.

(x) No action lies to compel the Executive Council to do any act or to recover damages. Cf. Church v. Middlemiss, 21 L. C. J. at p. 319 ; Lefroy, Legislative Pover in Canada, p. 97. 
regards its legality. The subject must he referred to later in connection with the question of the relations between the Governor and his Ministers, but in one sase at least no amount of support from Ministers is sufficient to relieve the Governor from criminal liability. Under the two Acts 11 \& 12 Will. 3 , c. 12 , and 42 Geo. 3 , c. 85 , any colonial Governor or other official is liable to be tried in England for a misdemeanour committed in the colony in the exercise of his functions as such Governor or officer. Resort was had to the statutes in the case of the Queen v. Eyre (y). Further, under the old Act 33 Hen. 8, c. 23, Governor Wall (z) was condemned and executed in 1802 for the murder of a soldier by flogging at Goree twenty years before. The latter Act is superseded by the Offences Against the Person Act, 1801, under which it is still open to try in England any person guilty of murder or manslaughter in any part of the world, provided he be a British subject. In neither case, whether the accusation be of murder or of a misdemeanour in office, is a colonial act sufficient to bar a prosecution in England, since the effect of colonial legislation is inadequate to affect the force of an Imperial Act. Of course, in practice, the difficulty would be surmounted by the refusal of the AttorneyGeneral in England to allow the proceedings to go on by entering a nolle prosequi, while, if this were not done and the officer were convicted, he could be saved from the effects of the condemnation by the exercise of the prerogative of mercy; but the theoretical difficulty still remains, and in point of fact a great deal of trouble might result from the anomalous position to a Governor, who was unfortunate enough to find himself the object of popular disapproval in England (a).

(y) L. R. 3 Q. B. 487 ; ef. Jenkyns, Brilish Rule and Jurisdiction beyond the Seas, pp. 138, 139.

(z) ״8 St. Tr. 51.

(a) These Acts seem only to authorise action if the accused is found in 
On the other hand, the Governor is not a subordinate officer of the Crown to whom the remedy of mandamus is applicable. This fact seems sufficiently obvious, for clearly the Governor would be placed in an impossible position if it were open for any person to endeavour to compel him to perform duties imposed on him by statute by proceedings in the Courts. Even if he could in each case avoid the issue of a rule absolute by showing that he had in fact exercised his discretion as to the act in question, nevertheless the trouble and indignity of having to answer in such cases would be intolerable. The point, however, seems only to have come recently under the consideration of the Courts. In the first case, one arising in British Guiana, where it was sought to mandamus a Governor to issue a licence for rubber, the Court decided the case on the statute which gives the Governor absolute discretion to refuse to issue licences at any time, but declined to decide the point as to the competence of an attempt to mandamus a Governor. But a Court of much higher judicial distinction, that of the Commonwealth of Australia, has formally ruled that a mandamus will not lie even against a State Governor to compel him to perform a statutory duty. The point arose from an attempt to issue a mandamus against the Governor of South Australia to hold an election for the purpose of returning a senator to Parliament. The Governor had been advised that the case was one for the appointment of a senator by the action of the State Parliament and not for a new election, and so declined to issue the necessary instructions for an election, and the High Court which obviously held, and indeed later on had occasion to decide that the proper course was to hold an election, expressly decided that no mandamus would lie against the Governor $(b)$.

Englund ; they would not, apparently, suffice as a ground for an application under the Fugitive Offenders Act, 1881.

(b) Commonwealth Parl. Papers, 1907; King v. Governor of South Australia, 4 C. L. R. 1497. 
Further, a colonial Governor, like every other servant of the Crown, is not liable for contracts made by him in his official capacity. In such cases the remedy of the subject lies by petition of right, at any rate, in any country in which the common law of England runs. It has been doubted $(c)$ whether the same rule applies to cases where the colony has never adopted the common law, as for instance, in the South African Colonies, and in Quebec, in Trinidad, in St. Lucia, in Mauritius, and in Ceylon. The point, indeed, is not of much practical consequence, as these Colonies have all either adopted Acts on the basis of the remedy by petition of right in English law, or have allowed an irregular but convenient practice to grow up of direct suits being brought against the Crown. But it is submitted that the opinion that the right to bring a petition of right should be regarded as in force also in Colonies where the common law does not run is correct; in its essence the petition of right involves merely the legal act of the Sovereign waiving the technical rules which forbid his being sued in his own Courts, and there is no conceivable reason why this exercise of the prerogative should not also extend to Colonies, where different systems of law prevail, as the royal prerogative is the same in all Colonies $(d)$. As a matter of fact there is no reported case in which a petition of right has failed in a colony where the common law does not apply, and all the Acts passed in these Colonies extend the right very considerably beyond its extent in English law, so that their existence

(c) Clode, Pctition of Right, pp. $36 \mathrm{seq}$. For the Quebec Petition of Right, ef. L. R. $9 \Lambda$ pp. Cas. 745 ; [1900] A. C. 103.

(d) Liquidntors of Maritime Bank of Canada v. Receiver-General of Nevo Brunswick, L. R. [1892] A. C. 437; cf. Exchange Bank of Canada v. Reg., L. R. 11 App. Cas. 43 ; Lefroy, Legislative Power in Canada, pp. 72-86; Commissioness of Taxation for New South Wales v. Palmer, L. R. [1907] A. C. $179 ; A .-G$. for New Sonth Wales v. Curator of Intestate Estates, ibid. 519 ; R. v. Laborde, Mauritius Reports, 1902, p. 71 ; of. Willians v. Hoscarth, L. R. [1905] A. C. 581. 
cannot be regarded as negativing the existence of the right independently of statute. Indeed some machinery Act seems essential, as otherwise the petition would require to receive the fiat from the Crown in England. For in this respect the colonial Governor has no delegation of the royal authority. It was explained in detail in $1897(e)$ to the Premiers at the colonial conference of that year, that if a petition of right were presented to his Majesty, it was the duty of the Secretary of State to consult the law officers in England, and on their advice to advise the Crown to grant or refuse a fiat $(f)$. It was contended by the colonial Premiers that the right must belong to the Government of the colony concerned in each case, whose advice should be accepted, even if it were formally necessary to consult the Crown; but the Secretary of State explained that he was advised that he could not legally accept this view. It is, therefore, open to every person who has a claim based on contract or quasi-contract with a colonial government, for which he cannot obtain satisfaction, to address a petition of right to the Crown, when, if there is a prima facie case for investigation, the petition will be endorsed with the words, "Let right be done in the Supreme Court of the Colony of __, " and the petition so endorsed will be sufficient warrant for the initiation of thecase in the Court in question. But such a right could be limited by colonial legislation, expressed to bind the Crown; although in no case does such legislation appear to have been passed $(g)$.

As head of the executive government the Governor

(e) Parl. Papers [C. 8596].

(f) Cf. Harrison Moore, Commonwealth of Australia, p. 220.

(g) For the Acts, cf. Clode, Petition of Right, App.; Harrison Moore, p. 265 , n. 2. In addition to the cases there given, the Commonwealth, Cape, Transvaal, and the Orange River Colony have passed similar legislation. For the duty of a Minister to subuit such a petition, of. Fulton v. Norton, L. R. [1908] A. C. 451. 
exercises a wide sphere of action, and no enumeration of his powers would be of use. Some, such as his power of pardon and of dissolving Parliament, and his share in legislation will be discussed below. Others of the powers expressly given by the Letters Patent constituting his office are practically never used, e.g., that of granting lands, such grants being made under legislative sanction.

A Governor is forbidden to leave his government without the permission of the Secretary of State. During his absence provision is made by the Letters Patent for the administration of the government by an officer, usually the Chief Justice of the Dominion, but in the Cape and the Transvaal the officer commanding the imperial forces. He is empowered to appoint a deputy during absence from headquarters or the State or colony for brief periods; this is provided for by the Constitution Acts in Canada and Australia, elsewhere it rests on the prerogative; in both cases the Governor still can exercise all his functions as well. Somewhat doubtful is the provision now inserted in the Letters Patent allowing the Governor to exercise his power while outside the colony for brief periods, as in Clause 12 of the Transvaal Letters Patent of the 6th December, $190 b^{\circ}$; it appears to me to be of doubtful validity, and to be open to serious criticism.

Governors are paid by the Dominions which they govern salaries fixed by the Parliaments, which, by law or custom, are not diminished during their tenure of office. 


\section{CHAPTER IV.}

\section{THE GOVERNOR AND MINISTERS.}

IN the preceding chapter we have sketched the main features of the position in law of the colonial Governor. But in a responsible Government colony the actual direction of the administration of affairs no longer rests in the hands of the Governor, but is entrusted to Ministers possessing the confidence of Parliament. In part, this result is brought about by the practice of the colonial legislature in entrusting, by Acts, specific duties to Ministers, which duties they can perform without reference to the Governor of the colony. It should be noted that even in these cases the Governor is not helpless. No Minister holds office save at his pleasure, and he can, in theory, always dismiss a Minister who insists on exercising the powers of his office in a manner opposed to those ideas of the Governor. In the majority of important matters, however, legal powers and duties are conferred by legislation either on the Governor or the Governor in Council. In the latter rase, the expression is sometimes defined to mean the Governor acting with the advice and consent of the Executive Council, as in the case of the Constitutions of Canada, the Canadian Provinces, the Commonwealth of Australia, the Transvaal, and the Orange River Colony. But even if this is not specified in the Constitution or Interpretation Act, the phrase is definitely understood by custom to mean the same thing. Again, in cases where the Governor alone is empowered to act, the Letters Patent and Royal Instructions eompel him 
to consult his Executive Council and generally to follow their advice. Moreover, as a matter of practical possibility, the Governor has no servants at his control, and to carry out a policy or even to do any important acts without his Ministers would be impossible.

On the other hand, there is no legal necessity $(a)$ on any Governor to act as his Ministers want him to do. His concurrence in their advice is necessary for the validity of their proposals in every case where the Governor is authorised to act, and if they will not agree with him, and he will not yield, they must resign or be dismissed, and the Governor may look about to find Ministers who will be in sympathy with his aims. This fact is expressed in the Royal Instructions in the form that, though the Governor must consult his Council, he may, if he shall see sufficient cause to dissent from the opinion of the Council, act in opposition to their opinion, reporting forthwith his action and the grounds thereof to the Secretary of State. Such a paragraph oceurs in the Royal Instructions to the Governors of the Cape, Natal, the Transvaal, the Orange River Colony, the six Australian States (b), Newfoundland and New Zealand. In the case of Canada, it appeared up to the date of the alteration of the Instructions made at the instance of Mr. Blake, on the occasion of the appoiutment of the Marquess of Lorne in 1878 , but, in asking for the deletion of the paragraph on the ground that it was in form in conflict with the established rule that, in a responsible Government colony, the Governor must, as a rule, act on the adrice of and through the agency of his Ministers, Mr. Blake was careful to admit that there was no desire to dispute the existence of the power or the propriety of its exercise in those cases where on

(a) Argued, even when the Lieuteuant-Governor alone was empowered to act, by Sir R. Finlay, in Fulton v. Norton, L. R. [1908] A. C. at p. 453.

(b) See Harrison Moore, Commonvealth of Australia, p. 380. 
imperial grounds it was thought that Canada had not full powers of determination of her policy $(c)$. Naturally the same precedent was followed on the occasion of the drafting of the first Instructions to the Governor-General of the Commonwealth. The Canadian Lieutenant-Governors are also expected to act on the same principle.

Mr. Blake's dictum, like those of many other authorities, restricts much too narrowly the right of the Governor to disagree with the advice of Ministers. But it is important to realise the great difference in the question, as it presents itself from the point of view of a mere matter of local interest and as a question involving imperial issues. In the former case the Governor must act in his capacity as the head of the colonial government; in the latter he must also remember that he is the servant of the Crown and the guardian of imperial interests, owing a duty to the Home Government paramount to his duty to the Dominion Legislature. The two cases rest on different principles and should be considered separately.

(a) The Governor as Head of the Colonial Goverument.

In the former case the Governor, as we have seen, can rarely, if ever, carry his policy into effect without the intervention of Ministers, so that his disagreement with Ministers must always result in either his giving way or in the yielding of his Ministers, or in their resignation, or even dismissal. No doubt a Ministry in the past have often yielded, and in the future may yield, to the earnest representations of a Governor, and have altered their policy in deference to his advice, but normally a colonial government is naturally not prepared to allow any interference with its policy, and will not remain in office, if it cannot secure the concurrence of a

(c) Canada, Sess. Papers, 1877, No. 13 ; ef. 1877, No. 181. 
colonial Governor in its acts. Again, it is clear that a contest on local matters between the Governor and the people of the colony can have only one ending : the Home Government will have to recall the Governor in order not to cause grave ill-feeling in the dependency. But admitting all this, there still remains a sphere in which the Governor has not merely freedom of action but also the duty and the right of deciding in matters of great public importance $(d)$. For it is his privilege to be able to cause an appeal to be made to the people on the occasion of any question of public importance, and on his exercise of the prerogative much of the future of the colony may depend.

Various attempts have, indeed, been made to prove that in this matter the position of the Governor is now practically identical with that of the Crown at home, and that the Governor must play merely the part of a constitutional monarch and leave it to his Ministers to demand and receive dissolutions at will. It is not necessary to decide how far this view is accurate of English conditions : at any rate there has been no recent example of the exercise of the technical right of the Crown to refuse Ministers a dissolution. The power, indeed, might, as recently suggested by Sir Charles Dilke $(e)$, be invoked on some crisis, but even that is doubtful. Nor is the reason far to seek. The failure of any attempt to decline to accept ministerial advice in England would have so bad an effect on the dynasty that the results might be incalculable injury to the country and

(d) It is, of course, obvious that Governors must not disagree in public speeches with their Ministers' policy, and is only worth mentioning because of the frequent violation of the rule (ef. the Hon. J. G. Jenkins, Journ. Royal Soc. of Arts, lvi. 346). The rule is only relaxed on departure from the Government (cf. Lord Northeote's speeches on leaving the Commonwealth, which were on all sides approved, because they were valedietory). Cf. also Sir John Macdonald, Canada House of Commons Debates, 1877, p. 373.

(e) Journ. Royal Soc. of Arts, Ivi. 344; but ef. Lord Aberdeen in Queen Victoria's Letters, iii. 287, with ibid. ii. 91. 
the system of constitutional monarchy. In the case of a Governor, if he goes wrong, he can retrace his steps with little more than a certain loss of prestige which an able man may make good in some other way, or at the worst there is only another name added to the list of those able men who for one reason or another have failed to distinguish themselves as colonial Governors. No doubt the occurrence of disputes of this sort is injurious to the imperial power in the Colonies, but it is not fatal, and therefore the colonial Governor has a right in reckoning chances to remember that the result of a false step will probably be his own recall, but nothing serious to the Empire. The taking of a certain amount of risk may accordingly be justified if there is at all a reasonable prospect of success attending the effort, and if the Governor is fully impressed with the necessity of action:

Hence all attempts to assert as part of the constitutional duty of a Governor the acceptance of the advice of his Ministers as to granting them a dissolution have failed. The demand was made in a reasoned minute $(f)$ by the Grovernment of Victoria, under Mr. Duffy's leadership in 1872, after a vote in the Assembly expressing no confidence in the Ministry: they argued on the constitutional practice of the United Kingdom that they were entitled to decide whether to ask for a dissolution or to resign, and they laid it down that a defeated party could properly ask for a dissolution in any of the following circumstances: (1) when a vote of no confidence is carried against a government which has not already appealed to the country ; (2) when there are reasonable grounds to believe that an adverse vote against the government does not represent the opinions and wishes of the country, and would be reversed by a new Parliament; (3) when the existing Parliament was elected nnder the

(f) Victoria Legislative Assembly Votes and Procetdings, 1872, No 45. 
auspices of the opponents of the government; (4) when the majority against a government is so small as to make it improbable that a strong government can be formed from the Opposition. They argued that all these conditions concurred in their case, and confidently asked for a dissolution. The Governor, Lord Canterbury, declined their request, on the ground that there was at least the chance that a government could be formed out of the Opposition ; and, in fact, though there is reason to think that an appeal to the constituencies would have resulted in a large majority for the Duffy Administration, Mr. Francis was able to form a government and to maintain it in office. In New Zealand the same question was revived with.characteristic impetuosity by sir George Grey in $1877(g)$. He asked for a dissolution because a vote of no confidence had just been rejected by the casting vote of the Speaker, and he based the claim for a dissolution on the ground that the Parliament had been elected under the auspices of the Opposition, and on the conviction that a general election would result in a large majority. The Governor, the Marquess of Normanby, declined to do so, because he had no confidence that a dissolution would result in a working majority for the government, and because no Supply had yet been granted. The Parliament was only in its second Session, and legislation as to representation was under consideration, which would demand a dissolution; and further, he thought that matters could be arranged without the trouble of a dissolution. In reply Ministers pressed the view that the power to dissolve Parliament was given to the Governor by the Constitution Act, and must be exereised by the Goreruor in accordance with ministerial advice; and they therefore demanded a dissolution unfettered by any conditions as to obtaining Supply, the Governor having intimated

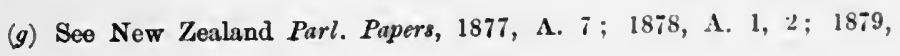


that Supply for at least three months should be obtained before dissolution. The Governor, however, declined to accept this view. He laid stress on the fact that the power to dissolve was given to him by the Constitution Act, while the Royal Instructions gave him power to decline the advice of Ministers when he thought fit. He consented at last to prorogue Parliament, but not to dissolve it; and when, after the prorogation, the Ministry renewed the argument, and again asserted the duty of the Governor to accept their advice, he remained firm, and the Secretary of State, when appealed to, approved his action, in a despatch of the 15th February, 1878 , in which he expressly declared his dissent from the doctrine of Sir George Grey as to the constitutional position of the Governor as regards the Ministry. As a matter of fact, the Ministry remained in office for about two years, and then obtained a dissolution from the Governor on defeat in the House of Representatives. On this occasion, however, the Governor insisted on the Ministry pledging themselves to arrange for the immediate issue of the writs for the summoning of a new Parliament, as tho two Houses had united in addresses to the Governor praying that steps should be taken that there should be no delay in the assembling of the fresh Parliament, in view of the difficult position of native affairs in the colony.

The same principles were asserted by Mr. Weld, the Governor of Tasmania, in 187 $i$, when his Ministers asked him for a dissolution, which he granted. He explained privately to his Ministers that the dissolution was only granted on the understanding that Supply would be obtained and that he would require Ministers to resign if Supply were not in fact voted; and in 1879, when again Ministers asked him to dissolve the House, he refused, and accepted the resignation of Ministers, on the ground that there was no great question at issue on which the country could be asked to decide, and 
there was every prospect of another Ministry managing to hold power $(h)$.

In the same year, in New South Wales, the question of dissolution without Supply had also arisen, and evoked an interesting correspondence between Lord Carnarvon and Sir Herules Rubinson. The latter had undertaken to grant a dissolution to Ministers conditionally on their obtaining Supply, and he appealed to the Secretary of State for advice as to whether there was any warrant in the procedure of the Imperial Parliament for such a mode of action. Lord Carnarvon consulted Sir T. Erskine May and the Speaker on the matter, and their opinions supported the desire of the Governor to secure the passing of Supply, it being the accepted practice in the Imperial Parliament for Supply to be granted on such occasions; thus permitting the people to decide on the state of parties without delay and without inconvenience to the public interests through lack of funds for current expenditure. Sir T. Erskine May, however, suggested that the Governor would have been better advised not to make the promise of dissolution formally depend on the advice of Ministers obtaining Supply, as he thereby gave the House the opportunity of deciding against its own dissolution by refusing Supply (i).

No change has been made since these precedents in the mode and extent of the Governor's exercise of the power of dissolution $(k)$, and he is thus enabled to play an important part in the government of any colony where the state of parties is at all equally divided, more especially in cases where the matter is complicated by differences of opinion between the two Houses. The following are very recent examples of the exercise of the

(h) Tasmania Legislative Council Journals, 187i, Sess. 2, No. 45; Sess. 4, No. $19: 1879$, No. 66 .

(i) New South Wales Legislative Assembly Votes and Proceedings, 1877-78, i. 451 .

(k) Cf. Harrison Moore, Commonwealth of Australia, p. 95. 
power. In the Commonwealth in 1904 the Governor-General declined to grant Mr. Watson a dissolution, as the two wings of the Opposition had arranged a coalition: and again, in 1905, the Governor-General declined to accept the advice of Mr. Reid to dissolve Parliament, the parties in the Parliament being equally divided, and the Protectionist wing of the coalition having secured a coalition with the Labour Party so as to defeat the Government. There was at that time no very great question before the country calling for a dissolution, but probably of more importance in the eyes of the Governor-General was the fact that, as events proved, the Opposition under Mr. Deakin and the Labour Party had combined to form a strong party sufficiently united to remain in office $(l)$. In 1906 the Governor of South Australia, on being advised to dissolve the newly-elected Parliament in order that the provisions of the Act of 1901 for settling deadlocks between the two Houses could be brought into operation, declined at first to do so, and only accepted ministerial advice after the attempt to form a new Ministry had failed, the Governor naturally not being prepared to grant a new Ministry a dissolution which he had refused to an old. As there was a question of considerable importance in view-the amendment of the Council Franchise-the action of the Governor in granting a dissolution obviously had warrant, but equally he was entitled to endeavour if possible to save the loss of public time and money resulting from a General Election, had any other party in the House been able to carry on the government $(m)$. In 19117 the Governor of Western Australia similarly declined a dissolution asked for by his Premier on the ground of grave differences between the Houses as to a

( $($ ) See, for Mr. Watson's case, Conmonwealth Parliamentury Debates, 1904, pp. 4265 seq., and for Mr. Reid's case, the Sydney Daily Telegraph, Argus, and Age for July, 1905 ; Commonwealth Parliamentary Debates, 1905, pp. 133 seq., 155 seq.

(m) South Australia House of Assembly Debates, 1906, Sess. 2, pp. 524 seq. 
land tax, but, instead of accepting the resignation which they then tendered, he induced them to agree to a prorogation of Parliament, and in the interval before the Houses met again the question in dispute was arranged amicably, avoiding a dissolution on a matter in which the real will of the people was notorious ( 1 ). In the same year after the dispute between the two Houses in Queensland, Lord Chelmsford declined to accept the proposals of his Premier for the swamping of the Upper House, and on his resignation accepted the advice of Mr. Philp that there should be a dissolution, though the House of Assembly protested vigorously that no dissolution was necessary. The Governor considered that there was a substantial question at issue-the position to be held by the Upper Chamber in the Parliament-and in point of fact the election did show so clearly the will of the people that the Upper House should not hamper reform that after the elections, which left Mr. Philp in a hopeless minority, and the return of Mr. Kidston to office, legislation was easily carried through both Houses providing for a referendum in cases of disagreement between the Houses. A protest was, however, formally made against the action of the Governor in dissolving, especially as the dissolution took place without the grant of Supply, and the progress of various desirable public works was delayed by the dissolution, and regret at the Governor's action was expressed in the address in reply to the speech from the throne at the opening of Parliament, while very vigorous attacks on his action were made during the electoral campaign in the country $(o)$. But the doctrine that a Governor cannot dissolve a House in the face of the refusal of Supply

(n) See his speech on the closing of the third Session of Parliament, Purliamentary Debates, Sept. 19th, 1907.

(o) Queensland Parliamentary Debates, 1908, pp. 38 seq., 88 seq. In 1896 no Supply was voted in Canada before the dissolution. Cf. Canada House of Commons Debates, 1896, Sess. 2, pp. 98 seq., 619 seq., and contrast Cape Howse of Assembly Debates, 1907, pp. $589 \mathrm{seq}$.

K. 
is obviously impossible to uphold, because the Parliament would then be set up as the sole arbiter of its fate as against the people, though no doubt the refusal to grant Supply is a fact to be taken into consideration in the exercise of the prerogative. Further, the dissolving the Assembly, despite its own protest, is a necessary consequence of the decision to grant a dissolution against the will of the majority in the House. In 1871 Sir James Fergusson, the Governor of South Australia, granted a dissolution in the face of protests from both Houses of Parliament $(p)$. Moreover, the confused state of parties, there being three nearly equal parties in the House, of which the Labour Party and that of Mr. Kidston stood in a loose alliance, rendered it hard to judge of the real wishes of the people, and the instability of the party alliances can be seen from the fact that in the new Parliament part of the government measures was passed by an alliance with the Labour Party, while the remainder was only got through by an understanding with the Opposition, which has grown into a sort of coalition. Peculiarly absurd, in any case, was the accusation levelled against the Governor of trying to set himself up as a dictator. There can hardly be any more popular action than an appeal to the people to decide the issues between the two parties, and if there are great issues the Governor is bound so to refer them, unless the views of the people are quite clear $(q)$.

In 1896 Lord Aberdeen declined to act on the advice of Ministers defeated at the General Election, and though attacked by Sir C. Tupper, his action was emphatically approved by Sir W. Laurier as a vindication of the right of

(p) South Australia Legislative Council Journals, 1871, p. 65; House of Assembly Journals, 1871, pp. 235 seq.

(q) For Lord Chelmsford's action, cf. Queensland Parliamentary Debates, 1908, Nos. 2 and 3 ; Morning Post, 25th April, 1908. 
the people to govern $(r)$. A Governor, too, has full discretion whom to summon on the resignation of a Ministry, as in England $(s)$.

\section{(b) The Governor as an Imperial Officer.}

On the other hand, very different considerations govern those cases where a Governor acts against ministerial advice on imperial grounds. In one respect the position of a Governor in these matters has been greatly simplified since the early days of responsible government. At that time the means of communication with the Home Government were very inadequate, and the position of colonial affairs not well understood by the Secretaries of State, so that a Governor had perforce to rely mainly on his own judgment, with the comforting assurance that the Home Government would repudiate him if he had acted counter to its ideas of what was constitutional. A.t the present time a Governor need and should never act on imperial grounds without fortifying himself with the advice of the Imperial Government obtained by telegraph. The dispute with the local government then becomes one between the two Governments, in which the Governor acts not as principal but as agent. The position is, of course, far more satisfactory than in the early days of responsible government, as it avoids any action on imperial grounds, which the Home Government is not anxious to put forward, and removes the matter from the sphere of a personal wrangle between Ministers and Governor.

The Royal Instructions to the Governor make very little allusion to this special function of the Governor. In the

(r) See Sir C. Tupper, Canada House of Commons Debates, 1896, Sess. 2, pp. 1623-1660; Sir W. Laurier, ibid. 1660-1671. Note the Speaker's rebukes to Sir C. Tupper, as attacking the Governor-General and not the new Ministers, ibid. 1638, 1656, and cf. Canada Sess. Papers, 1896, Sess. 2, No. 7.

(s) Morley, Life of Gladstone, ii. 621 seq. 
case of Newfoundland and the Cape, there is no mention of or allusion to it whatever, even as regards the prerogative of pardon. In the six Australian States, New Zealand, the Commonwealth, and Canada, there is only a reference in the Instructions as to pardon to the interests of other parts of the Empire, or of foreign countries; but in the case of Natal, the Governor is given a special position as Supreme Chief of the native tribes, and in the exercise of his functions in that regard is directed to decide, after consultation with his Ministers, but on his own responsibility. In the case of the Transvaal $(t)$ and the Orange River Colony $(u)$, the Governor retains all the vague rights of paramount chief over the natives, and he is presumably intended to carry out these duties on the same system as in Natal after consulting Ministers, but on his own responsibility. But the general rule is part of the constitutional law of the Colonies that the Governor is not bound to accept ministerial advice, whenever it runs counter to imperial interests, or, what nowadays is pretty much the same thing, to interests deemed by the Secretary of State to be of so much imperial importance as to justify disagreement from the colonial authorities $(x)$.

In the case of legislation, a more precise definition of imperial interests can conveniently be deduced from the lists of subjects, Bills relative to which the Governor is required by his instructions to reserve. These topics, examples of which will be found in the next chapter, include divorce, currency, treaty relations, differential duties, the control of the troops or the navy, and Bills of an unusual purport affecting the prerogative or the rights and property of British subjects not resident in the colony, or the trade and shipping of the United Kingdom. The question of immigration is covered, in part

(t) Letters Patent, Dec. 6th, 1906, s. 51.

(u) Ibid., June 5th, 1907, s. 52.

(x) Cf. Dilke, Journ. Royal Soc. of Arts, lvi. 344. 
at least, by the provision for the reservation of Bills affecting British subjects not resident in the colony ; while legislation affecting in a differential manner natives from those of European descent is required to be reserved in the Transvaal, the Orange River Colony, and Natal. If we add to the heads that of the treatment of public lands we obtain nearly all the matters in which the control of the Imperial Government over the responsible Grovernment Colonies has been attempted to be exercised.

A question of grave constitutional importance $(y)$ arises out of the position resulting from the action of a Governor in obedience to Imperial Instructions in differing from ministerial advice. There is, undoubtedly, at present in the Colonies a tendency in Ministers to regard the action of the Governor in the same light as when he declines to accept their advice on a matter of local importance only, and to insist that they have the constitutional right to resign in the circumstances, leaving the Governor to yield or to find new Ministers. Now it must at once be observed that such a claim, if pushed to its logical conclusion, must be fatal to the unity of the Empire and to its present juridical Constitution, which is based on the theory that there is, in the last resort, an imperial unity and a power capable of making itself obeyed. No doubt it is theoretically possible for the Imperial Government to secure obedience by revoking the Constitution of the Dominion concerned, but that would be a step which could only prelude the dismemberment of the Empire, a step which, even in a modified form, the Imperial Government declined to take when it was petitioned for by many people in the Cape during the late war $(z)$. Similar difficulties were seen recently in the matter of Japanese immigration into the

(y) Cf. Journ. Royal Sx. of Arts, lvi. 337; Sir C. Dilke, Hansard, cxc. 113-115; Mr. Evans, M. L. A. Parl. Papers [Cd. 4328], g. 77.

(z) Parl. Papers [Cd. 1162]. 
United States when the Californian Government practically declined to make good the obligations of the Federation. It is very possible that the present Constitution of the Empire is not one which can be permanent; but as long as it remains it is, it is submitted, the duty of a Dominion Government, in the last event, to accept the determination of the Imperial Government, under protest if necessary, and with the intention of securing the alteration in the position adopted by that Government, but, at any rate, resolved for the time to concur. On the other hand, it is certain that the Imperial Government is bound to take every step to secure that its policy shall not run counter to that of any Dominion Government save in matters of the greatest importance to the Empire as a whole.

The difficulties of the position may be illustrated by a few examples. As early as 1859 the Canadian Government argued that any attempt of the Imperial Government to interfere with the Customs policy of the Dominion was inadmissible, unless the imperial authorities were prepared to undertake the responsibility of administering the whole Government of Canada $(a)$. The rebuke was, on the whole, justified. It is clear that matters of finance cannot possibly be taken out of the hands of those who are bound to manage the affairs of a colony, just as conversely, in the Crown Colonies, the Imperial Government retains the supreme control of all tinancial measures, however far they may be prepared to go in allowing the local legislatures to legislate in matters not of financial importance $(b)$. In 1878 the question was keenly discussed at the Cape, as will be seen later, whether a Governor could, without the consent of Ministers, transfer the colonial forces to the imperial control,

(a) House of Commons Papers, 1864, xli. 79.

(b) Cf. the case of Jamaica, Parl. Papers, [C. 9177], [C. 9412], [C. 9413], [Cd. 125]. 
and the result arrived at was that such transfer required the support of Ministers, both in order to make it effective and on the broad constitutional ground of the nature of colonial self-government $(c)$. In 1877 there was a dispute in Tasmania with regard to the case of one Louisa Hunt, who was pardoned, on the advice of Ministers, by the Governor, and the advice given by Ministers was censured by both Houses of Parliament. The government did not, however, deem it necessary to resign on that account, because they held that the matter was one in which the final responsibility for the decision rested with the Governor, not with Ministers $(l)$. In 1880, Mr. Todd (e) laid down the doctrine as to the action of Ministers in such circumstances as follows:- "In all such cases the responsibility of the local Ministers to the local parliament would naturally be limited. They would be responsible for the advice they gave, but could not strictly be held accountable for their advice not having prevailed," and he quoted the following definition of the position from a despatch from Lord Carnarvon $(f)$ : "If it be the right and duty of the Governor to act in any case contrary to the advice of his Ministers, they cannot be held responsible for his action, and should not feel themselves justified on account of it in retiring from the administration of public affairs." This statement of the case was adopted in 1892 by Mr. Ballance's Ministry in New Zealand in their dispute with Lord Glasgow. The Ministry desired the appointment of twelve members to the Legislative Council, in order to overcome the opposition of that body to their measures, and the Governor considered that in order to avoid swamping the Council not more than nine should be appointed, and he

(c) Parl. Papers [C. 2079].

(d) Tasmania Legislative Council Journals, 1878, Nos. 35, 36.

(e) Parl. Goot. p. 590.

(f) Cited in Canada Sess. Papers, 1876, No. 116, p. 82. 
definitely declined to accept the advice tendered to him : the Ministry then appealed to the Secretary of State, but did not resign, quoting in favour of their attitude the passage in Todd's work just quoted. The Governor thought that in so acting he was carrying out his duty as an imperial officer, and there was a good deal of precedent for his view, though in point of fact the Imperial Government decided that there was no imperial interest involved, and laid down in Lord Ripon's despatch of the 26th September, 1892-a day now made the Dominion Day of the colony - that where no imperial interests were involved the Governor should, as a matter of course, accept the advice of his Ministers, unless he was prepared to find others in case of their resignation $(g)$.

The most recent examples of such disputes do not altogether agree. In the case of Natal in 1906, the Natal Government proclaimed martial law, and ordered under it the execution of twelve natives on charges of murder. The Imperial Government then proceeded to suggest to the government the suspension of the order pending the further consideration of the question $(h)$. The Ministry then resigned, and only consented to hold office pending the appointment of their successors. As the colony was then on the brink of a native rebellion and there was no chance of the formation of a newgovernment-even if the crisis had permitted the colony to remain in the throes of a change of Ministries-the Imperial Government revoked the suggestion of suspending the executions, further information having by that time arrived showing that the men were clearly guilty of murder. At the same time the Imperial Government expressed the view that

(g) Parl. Papers, H. C. 198, 1893-94, p. 48, A different interpretation of the correspondence seems to have been put on it by Lord Chelmsford in Queensland in 1907. Cf. the Hon. J. Taverner, Journ. Royal Soc. of Arts, lvi. 346.

(h) Parl. Papers [Cd. 2905]. 
the Ministry had been somewhat hasty in resigning under the circumstances and without any previous consultation with the Imperial Government, and that criticism seems clearly justified. On the other hand, in the case of Newfoundland in 1907 the Imperial Government, in enforcing the treaty rights of the United States in the colonial waters, found it necessary, in view of the divergence of opinion between the governments of the United Kingdom and of the colony, to issue an Order in Council under an imperial Act of 1819, in part suspending the operation of a colonial law $(i)$. But while the local government resented this step and protested violently against it, it did not, despite the taunts of the Opposition, resign, but remained in office on the ground that the Ministry was not entitled to resign, because they were not able to persuade the Imperial Government to accept their views of the rights of Newfoundland, and the mode of procedure to be adopted to enforce them. Their action seems to have been perfectly constitutional; whether or not a new Ministry can be formed, there seems no justification for a government resigning merely to coerce the Imperial Government, and it is important to note that in the dispute with the Imperial Government as to Dinuzulu's salary and martial law in 1908 the Natal Government did not resign $(k)$.

But this question remains one of the most difficult of the problems of the imperial relations. It cannot, perhaps, be satisfactorily solved until federation is, if ever, accomplished; but in the meantime it is obvious that it will not be advantageous for federation if the several parts of the Empire have assumed the habit of disregard of imperial unity. This is the cousideration which renders it essential to uphold the technical right of the Imperial Parliament to legislate for the

(i) Parl. Papers [Cd. 3765].

(k) Cf. Parl. Papers [Cd. 4194], [Cd. 4195], [Cd. 4328]; cf. the summary [Cd. 4328], pp. $63 \mathrm{seq}$. 
Empire as a whole, the sole right of that government to conclude treaties, the power to disallow acts, and so forth.

As an imperial officer the Governor is, of course, bound to follow the directions of the Secretary of State. Such obedience is indeed expressly laid down in his Letters Patent, where it is provided that the Governor is to follow the instructions given him either by Order in Council or under the Sign Manual, or through a Secretary of State. The latter mode is the usual method of procedure, and nowadays the orders given are not usually couched in the name of the Crown; nevertheless, the authority to give them must be considered as derived from the Crown, and indeed the Secretary of State has his power as the mouthpiece of the Crown, and in no other capacity. A more or less permanent set of such instructions is contained in the Colonial Regulations, of which a revised edition has just been issued, while a clause in the list of Bills to which a Governor is not permitted to assent reminds the reader of the old struggles against the habit of Governors accepting presentations. As late as 1855 Sir William Denison accepted a grant of 2,000l. from the people of Tasmania $(l)$, and in 1867 and 1868 efforts were made by the Assembly of Victoria to bestow on Lady Darling the sum of 20,000l. as a reward for her husband's services to the Assembly in its contests with the Council which had led to his recall from his Government $(m)$. In 1571 Sir George Bowen insisted on the more salutary practice of accepting a valuable gift only on behalf of and for the use of the Governor for the time being ( $n)$, and since that date the rigid rule has been laid down that no Governor shall accept any present from the people under his government

(l) Denison, Life, i. 274.

(m) House of Commons Papers, 1867.68, xlviii. 630-704. Later, after his death, his widow received a pension from Victoria: Act No. 362, 1870.

(n) House of Commons Paper's, 1872, xliii. 664. 
save with the permission of the Secretary of State, which will only be granted on exceptional grounds (o). Governors are also forbidden to take part in any commercial concern within their government-an inconvenient practice which may lead, as has been known to be the case, to actions being brought against a Governor for private debts in the Courts of the colony over which he is Governor $(p)$.

The imperial control can be enforced at any moment by the recall of the Governor, who is appointed nominally for a term of six years $(q)$. It is, of course, also open to Parliament to censure his conduct in any case, and there are various examples of efforts to do so, some successful, some not. In 1868 the conduct of the Governor of Victoria in regard to the quarrel between the Council and the Assembly was severely criticised in the Imperial Parliament; and in 1879 there was a heated debate over the conduct of Sir Bartle Frere in regard to the native war in South Africa, when the Government, while avoiding defeat, still found it necessary to admit that the Governor had not acted properly or with sufficient regard to the imperial authorities $(r)$. There are several similar cases of attacks on Crown Colony Governors, and in 1906 Lord Milner's conduct in South Africa was criticised in the House.

It should, however, be noted that the fact that the Governor has acted against his iustructions, does not in any way invalidate his acts, except where the instructions have the force of law. The point used, before 1865 , to arise in the case of the Royal Instructions given to regulate the assent of Governors to colonial Acts. These instructions were referred to, though not specified, in the Constitution Acts of the several Colonies, and it was held by some, with a good deal of force, that an assent given in contravention of instructions

(o) Colonial Regulations, No. 46.

(p) Parl. Papers [Cd. 3402].

(q) Colonial Regulations, No. 7 (ed. of 1907, omitted in ed. of 1908).

(r) Hansard, ccxliv. 1606, 1865. 
must be a mere nullity. On the other hand, the instructions were often vague in terms, and it would have been very inconvenient to make, in each case, a matter of judicial decision whether or no a particular Act overrode the instructions or not. At any rate, the Colonial Laws Validity Act, 1865, definitely concluded the difficulty by deciding that the instructions should in no case affect the validity of the assent, even if they were referred to-as opposed to specified in detail-in the constitutional instrument. In the case of other instructions there can be still less reason to ascribe to them the force of law. The Governor should obey them, but they are wide in terms, and if he fails or disobeys the matter is one between him and the Secretary of State, not a matter for legal notice. Of course, if his acts are beyond the powers delegated, they may be simply void-for example, no Governor could confer a valid title of honour, or take command of a man-of-war $(s)$, or so forth-but normally the act would be, however improper, legally valid.

By his Letters Patent the Governor is also instructed to obey the laws in force in the Dominion of which he is Governor. This instruction, of course, adds nothing to the legal obligation of a Governor to obey the law of the colony ; he is in no way above it, and the command merely reminds him of the paramount duty of obeying the law. It is a duty which may bring him into conflict with Ministers, but it is none the less binding on him for that reason $(t)$. It was asserted with great clearness by the Imperial Government in 1866 when they recalled the Governor of Victoria, Sir Charles Darling, because of his raising a loan and allowing the expenditure of public money without the consent of Parliament; and the same rule was laid down in a long correspondence, 1867-1870, between the Governor of New South Wales, the Earl of Belmore, and his Ministers, and the

(s) Colonial Regulations, No. 10 (ed. of 1908).

(t) Cf. Anson, Law of the Constitution, ii. 279. 
Secretary of State, regarding the issue of public money in the colony $(u)$. The Earl Granville decided that under no circumstances, save those of pressing need, could there be issues of public money without the approval of Parliament, and he entirely disagreed from the view which the Governor was inclined to take, that it would be legitimate to issue the salaries of civil servants in advance $(x)$. In 1878 the Secretary of State took exception to the action of the Governor of Victoria in assenting to wholesale dismissals of civil servants, in order to enable the government to carry on for a longer period without Supply, which was delayed by the dispute with the Council. It was then explained by Sir Michael Hicks-Beach in a despatch of 5th July, $1878(y)$, that the Governor was bound, above all persons, to see that the law of the land was respected, and that he could not by ministerial advice avoid that responsibility. In general, he would be justified in deciding to accept the advice on a legal topic of his law officers, provided that it were given as legal advice, and not as political advice, but even then he could and must exercise his own discretion. In some cases he might, despite the fact that the act proposed could not be asserted to be legal, still approve it, but the responsibility was a grave one, and should only be incurred in a very serious crisis. The force of the reasoning is conclusive, and the instructions still have full effect. As was pointed out by Lord Granville in 1870 , the colonial legislature can pass whatever rules of law it likes, but the Governor must not anticipate the passing of such a law on the advice of a Ministry.

The rule has ever since been generally followed in the Dominions. It depends a good deal on the precise terms of

(u) Parl. Papers [C. 2173], pp. 114-132.

(x) In the Dominions the Governor's warrant is always a necessary pre. liminary to the issue of public money under the Constitution Acts.

(y) Parl. Papers [C. 2173], p. 81. 
the local law whether the action of a Governor is or is not to be deemed legal and constitutional. For example, in 1896, the new Ministry in Canada recommended the issue of certain sums by the Governor-General, and his action in accepting their advice was questioned, on legal and constitutional grounds, by Sir Charles Tupper (z). On the other hand, in 1908, despite constant obstruction in the House of Commons, the Dominion Government were not prepared to advise the issue of funds, even to pay civil servants, without a vote of Parliament. In 190\%, on the other hand, the new Ministry in Queensland, being unable to procure Supply from the hostile House, advised the Governor to dissolve, and, to carry on the government, asked him to sign warrants for the payments of very large sums. He consented to do so on a certificate furnished by the Attorney-General, acting as his law officer, and not as a Minister, that there were precedents for such a course-a fact undeniable in Australia, where the system of granting Supply is traditionally unsatisfactory. His action was bitterly attacked during the political crisis in the country as contrary to law, and the new Ministry on taking office, after the resignation of Mr. Philp, in face of the results of the General Election, showed its financial purism by declining even to pay weekly wages without an Act of Parliament, and for a long time hesitated to make good the payments, without Parliamentary authority, made by their predecessors.

Much more important questions arise in connection with the right of proclaiming martial law. In no self-governing colony is martial law part of the ordinary law of the land,

(z) Canada House of Commons Debates, 1896, Sess. 2, pp. 58 seq., 619-714; cf. Sir R. Cartwright, ibid. 1891, vol. iii. pp. 4540 seq. The Government retorted that the late government should have obtained Supply instead of spending the session just before Parliament expired by efflux of time on an attempt to coerce Manitoba. Cf. Egerton, Canada, pp. 322, 323. See also Sir C. Tupper, ibid. (1896), p. 1657, on a Governor's duty. 
and therefore the action of the Governor is not exercised on any statutory basis. Nor is there in any proper sense a common law right of proclaiming martial law; it is no part of the prerogative to set up by a proclamation a state of affairs different from that prevailing under the law of the land. On the other hand, a proclamation of martial law does not necessarily involve any illegality, nor in any case can the mere proclamation be in itself illegal, however injudicious it may be. For, after all, such a proclamation merely means that a disturbed condition of affairs exists, and that the government is determined to resort to extraordinary measures to put it down. Such measures may be of two kinds: in the first place they may rest on what is the undoubted common law of the Dominions, which base their law on English law, that every person, and above all every government official, is bound to spare no steps to secure the supremacy of the law and to repress disorder and rebellions $(a)$. In the second place the government may mean to go beyond this and to violate law by taking steps which in their opinion are necessary, even though in strict law they would not be held by Courts justifiable under the first ground. In those Dominions in which the Roman-Dutch law prevails there is no difference in the legal aspect: the ground on which action, which would normally be a disregard of the ordinary law, is justified-salus reipublice suprema lex -exists also in that system of jurisprudence.

It may, however, be assumed as certain that in a case of the proclamation of martial law the government will exceed the powers which belong to it at common law, and will

(a) See Dicey, Law of the Constitution, ed. 7, pp. 533 seq., and the series of articles in the Law Quarterly Revieu, xviii. The only new materials of importance are the two cases, Trlorkio v. Att.-Gen. of Natal, L. R. [1907] A. C. 93,461 , which merely establish the doctrines already accepted, that an Act of Indemnity bars any interference of the Law Courts and that courts-martial are not Courts in any legal sense. Cf. [1903] T. S. 413. 
violate rights beyond what is permitted by the law. It is well to remember that much of what is done under martial law is in no way contrary to the ordinary law of the land, which permits what are usually counted as rights to be over-ridden by necessity, but in every recent case of the proclamation of martial law there has been passed an Indemnity Act to cover all acts done in good faith by the colonial government. In 1866-7, the New Zealand Government had a dispute with the Imperial Government over the terms of a Bill passed by the colonial Parliament to indemnify the government for steps taken under martial law in repressing a native rebellion. The Bill was reserved and not sanctioned by the Imperial Government $(b)$, because it was not limited in terms to making valid acts done in good faith by those officers engaged in suppressing the revolt, but was a simple indemnity for all persons acting by instructions of any officer without qualification, and the imperial precedents show that an Indemnity Act if confined, as it properly should be, to acts done in good faith, leaves it open to the Courts to punish wanton cruelty perpetrated by persons who fancy that the proclamation of martial law leaves them free to commit any illegality $(c)$. The most recent cases of Indemnity Acts in the Cape (Nos. 4 and 10 of 1902) and the Natal (No. 22 of 1902) after the Boer war, during which the Governor had perforce to disregard the ordinary law, were restricted to acts done in good faith in the process of earrying out the repression of the disturbances in the colonies due to the war and the rebellions. On the other hand, the Indemnity Act passed in Natal in 1906 (No. 51) to cover the acts done by the government in the suppression of the rebellion among the natives in that year was exposed to some criticism both in England and in

(b) New Zealand Parliamentary Debates, i. 1023 (desp. May 15th, 1867).

(c) Wright v. Fitzgerald, 27 St. Tr. 759. 
the colony, as its operation was not merely retrospective, but contemplated the legalization of steps to be taken for the further suppression of the revolt. It was, however, sanctioned by the Imperial Government, partly because it was desirable to terminate the rule of martial law in the colony, and the colonial Ministry were not prepared to withdraw martial law as long as there was no Indemnity Act in force $(d)$.

Serious problems have also arisen in connection with the proclamation of martial law by the Natal Government in 1907 , and the continuauce of the system in 1908, though as a matter of fact little use was made of its provisions. In the first place, the difficulty arises whether martial law can be proclaimed unless there is actually armed insurrection on a large scale in the colony. The reply to that question seems to be that the mere proclamation in itself can hardly be illegal. Secondly, it may be doubted whether the operation of martial law in such a case can possibly be legal. The answer to this seems to be that the matter is one entirely for the Courts to decide. The Privy Council has laid down in the cases of Marais $(e)$ and $\operatorname{Van}$ Reenen $(f)$ that the Courts should not and are not entitled to interfere in a case in which there is actual war being waged, but it is still for the Court to decide whether there is war being waged $(g)$, and whether its jurisdiction is ousted-a matter of fact rather than of law. Thirdly, it is doubted whether the Governor is bound to act on ministerial advice in proclaiming martial law. The answer, if the mere legal

(d) Parl. Papers [Cd. 3247], pp. 36, 92-94. The Act declares done in good faith all acts of civil or military officiuls, but other persons' acts are covered only if done under direction of such otficisls or in good faith.

(e) L. R. [1902] A. C. 109.

(f) L. R. [1904] A. C. 114. Cf. Natal case, Msolo and Groana v. Rex, Parl. Papers [Cd. 3247], pp. 8, 9.

(g) Cf. Lord Halsbury's language in Tilonko v. Att.-Gen. of Natal, L. R. [1908] A. C. 93 , at p. 95 .

K. 
point is considered, is clearly in the negative, inasmuch as the Governor is not and cannot be bound to accept the advice of Ministers on this or any other topic. But it must be admitted that it would be a very strong step for a Governor to decline to declare martial law on the advice of Ministers. They are responsible for the government of the country, and if they assure the representative of the Crown that they cannot maintain order, the Governor assumes a serious burden of responsibility if he declines their advice without being able to procure Ministers in their place $(h)$. It follows, therefore, that in such a matter the rule of following the advice of Ministers must nearly always prevail, provided that the Governor does not manage to secure the modification of his Ministers' proposals by the exertion of his personal influence. Similar considerations also apply to the use of the imperial power of disallowing such Bills as Indemnity Bills $(i)$. Disallowance would amount to a declaration that the colonial government had been guilty of mismanagement, and that the Imperial Government did not consider it competent to govern, a conclusion which would logically demand that the Imperial Government should assume the control over the colony.

One or two further points in the relations of the Governor and his Ministers may be mentioned. The appointment of a Governor is now never made contrary to the wishes of the

(h) Cf. Hansard, 1908, clxxxv. 336, 672; clxxxvi. 1076.

(i) On martial law in Natal, ef. the debate, Hansard, 1908, cxc. 102-129, on the Indemnity Act, ibid. cxciii. 2101, al.; and see Parl. Papers [Cd. 4194], [Cd. 4195], [Cd. 4328], at pp. 88 seq. of which the Act No. 5 of $19 n 8$ is printed, and on p. 103 are given the objections of His Majesty's Government to the Act, as giving protection to improper acts. The same Papers contain the correspondence as to the stoppage of Dinizulu's salary, which the colonial government finally decided to pay in the shape of a contribution to the cost of his defence ([Cd. 4328], p. 32). See also p. 29 for the Governor's view of the impropriety of the continuance of martial law when no war was going on. 
Ministry. At one time the colony was assumed to be ready to accept any person whom the Crown might deem fit to be appointed to govern, but after the refusal of Queensland in 1888 to accept Sir Henry Blake as Governor, followed by the refusal of South Australia to accept the Marquess of Normanby, the sounder constitutional doctrine was established that the colony should in effect be told of the nature of the appointment proposed before it was formally concluded $(k)$. This of course falls a great deal short of allowing the colony to select its own Governor, as the right of suggestion has not yet been formally conceded. But there must always be the power of choice in the Crown under the present system of constitutional government in the Colonies, since in the Governor lies the power of intervention on behalf of the imperial interests, and on him devolves the duty of keeping the Imperial Government informed of affairs affecting imperial interests. The move for local appointments that has been formally made by South Australia $(l)$ and which is now becoming a formidable one in the Australian States-even in Victoria the lower House is, as shown by a debate in 1907, when the government majority sunk, despite the Premier's intervention, to two, clearly in favour of it though the plan is not accepted by the government and though the delegates of the States at the conference of 1907 decided in favour of the retention of the existing system-ignores the great difficulties in the way of any such arrangement. To the Imperial Government the Gorernor is the means of exercising imperial control, while the colony or State benefits by having at its head a man who, whatever his demerits, is yet not a party politician, and who can be expected to be impartial in a crisis. In a local

(k) Parl. Papers [C. 5828].

(l) See House of Assembly Debates, July 29th, 1908; Legislative Conneil Debates, Aug. 18th, Sept. 30th, Oct. 7th, 1908; Age, Aug. 5th, 1908; Register, Oct. 1st, 1908. 
man the Imperial Government could not expect the same readiness to understand their views, or the same lack of prejudice in party questions.

As long as the Governor remains in that position, it is the duty of the Ministry either to support and defend him or to resign, and to leave him the chance of getting new Ministers who will defend him. The only exception to this rule would appear to be in the case of an address to the Crown for the removal of an obnoxious Governor; such an address would clearly be within the rights of a legislature, and would be the proper mode of procedure in such a case. Examples are, however, on record of proceedings tantamount to a vote of censure being passed or proposed. In 1861 it was proposed to censure Sir William Denison for himself affixing the seal of the colony to a land grant, for which his government declined to accept responsibility, but the attempt failed on the previous question being $\operatorname{moved}(m)$. In 1877 the Governor of Tasmania was pronounced by the Assembly to have made inaccurate statements, and to have consequently made wrong deductions from the statements $(n)$. In 1878 an attempt was made in the Assembly of the Cape to resolve that the Governor had acted beyond the scope of his constitutional duties; that his acts had been prejudicial to the interests of the colony, and had delayed the termination of the native rising; but the Speaker pronounced the resolutions out of order, and the Governor was upheld on the real issue by the constituencies (o). In 1877 the Marquess of Normanby declined to make a certain appointment to the Legislative Council of New Zealand while a vote of censure was impending against his Ministers; whereupon Ministers

(m) New South Wales Legislative Assembly Votes, 1861, i. 647-743.

(n) Tasmania Legislative Council Journals, 1877, Sess. 2, No. 45; Sess. 4, No. 19.

(o) Cape House of Assembly Votes and Proceedings, May 29th, 1878. 
laid the papers before the House of Representatives and secured a vote of censure against the Governor for taking notice of matters pending in Parliament. The Governor urged that Ministers should support him in Parliament or resign, and leave him free to get a government who would support him; but Ministers would not resign and would not admit that they were bound to support him, but reiterated complaints that he had not accepted their advice $e x$ initio. The Governor was, however, upheld in his action by the Secretary of State $(p)$. Again, in 1908, the Queensland Parliament replied to the speech from the Throne in an address which practically censured the Governor for granting Mr. Philp a dissolution in 1907 against the desire of the Assembly, but no further steps were taken to proceed against the Governor for his action.

It may be added that a Governor has various duties to perform under Imperial Acts and not as a colonial officer; e.g., under the Fugitive Offenders Act, 1881; under the Extradition Acts, 1870 and 1873; under the Merchant Shipping Act, 1894 ; under the Territorial Waters Jurisdiction Act, 1878; under the Army Act, 1881; under the Pacific Islanders' Protection Acts, 1872 and 1875 ; under the Naturalisation Act, 1870 , \&c. In all these cases the Governor should consult his Ministers, even if he does not accept their advice. It is true that he is not legally bound to do so; compare, for instance, the Pacific Islanders' Protection Act, 1872, which distinguishes between Governor and Governor in Council; but the propriety of his doing so is manifest, and he has no executive means of action save through Ministers ( $q$ ).

(p) New Zealand Gazette, June 21st, 1878.

(q) Cf. Parl. Papers, H. C. 194, 1890, p. 8 (opinion of Canadian Privy Council). The Australian Navigation Bill [Cd. 3826] and the New Zealand Act of 1903 transfer to the Ministry the duty of sanctioning prosecutions under the Merchant Shipping Act, 1894, s. 457, and, if Lot altogether intra vires (save under sects. 735,736 ), the practice is common sense. 


\section{CHAPTER V.}

\section{CABINET GOVERNMENT IN THE DOMINIONS.}

Ir is a striking fact, however it may be explained, that in no colony has any real change been made from the established rules in force in the United Kingdom as to the mode of conducting government under a Parliamentary executive. All the formal rules which are in force in the English Parliamentary system have been adopted as the basis of colonial responsible government, and deviations from the model are few and unimportant. Further, the great majority of the rules actually observed are merely constitutional practices, not legal regulations. As late as 1892 the Imperial Government declined to accept a proposed clause in the Natal Constitution Act in which it was laid down that the Ministers should constitute the executive Council, on the ground that such a provision was out of place in a Constitution Act of which the primary object is the creation of legislative chambers and the regulation of their functions, while the object in view would equally well be obtained in another way. "In fact," Lord Knutsford (a) wrote, "throughout the Colonies the resignation by colonial Ministers of their seats in the executive Council is rather a matter of unwritten practice than of positive law." In every case save those of Canada (b), its provinces, and the Commonwealth $(c)$, the executive Council

(a) Parl. Papers [C. 7013], p. 41.

(b) 30 Vict. c. 3 , s. 11.

(c) Constitution, s. 62. The Victorian Acts, Nos. 1075, s. 13, and 1864, s. 8, make certain Ministers members of the Council, but do not constitute it, Parl. Papers, H. C. 70, 1889, p. 35. So the South Australian Act, No. 2 of $1855-1856$, s. 32 . 
owes its official existence formally to the Letters Patent issued under the prerogative constituting the office of Governor.

As a matter of fact, the members of the executive or Privy Councils of Canada, Tasmania, Victoria and the Cape do not resign their seats when the Ministry of which they are members ceases to hold office. The position of such members of the Privy Councils of the Colonies may be compared with that of the ordinary members of the Privy Council in England, but the parallel is not exact. For in passing Orders in Council in England any Privy Councillor may serve as one of those summoned to be present at the making of the Order-and as a matter of fact very many, perhaps the most, of such Orders are made without the presence of more than one or two Ministers at the outside; as far as can be ascertained there is no parallel to this practice in the Colonies, where the membership of the Privy Council is purely honorary, giving the member the right to the title Honourable and to the special precedence assigned to Privy Councillors not of the Cabinet, and to be present when the Governor is sworn in.

This survival has no special value $(d)$, and, as explained in 1892 by Lord Knutsford, the more convenient practice is that the members of the executive Council should resign office with the fall of their goverument; if any executive councillor refused to do so, the same result could be produced by dismissal by the Governor, who has full power to do so under his Letters Patent. In another respect, also, the Colonies have retained the practice of the Imperial Parliament in an inconvenient fashion, viz., in requiring the resignation of members of Parliament on appointment as Ministers, if they are members of the elective Lower or Upper Houses. Fortunately there are signs of the disappearance of this inconvenient and unnecessary custom; it is not in force in the Common-

(d) Cf. Harrison Moore, Commonuealth of Australia, pp. 224-226. 
wealth of Australia, in New Zealand, South Australia, Cape, Natal, the Transvaal or the Orange River Colony, and it is probably only a question of time for it to disappear from all the Dominion Parliaments. Mr. Todd $(e)$ indeed was opposed to the change as tending to increase the instability of Ministries by lending itself to the custom of frequent changes of the personnel of the administration, but the counterbalancing disadvantages of unnecessary elections and waste of time are of much greater weight, especially when it is borne in mind that the length of a Parliament in the Colonies is usually much shorter than in England, usually three or at most five years.

The chief differences between the colonial Cabinet system and that of the United Kingdom arise from the lack of the same clearly defined parties in the Colonies. All sorts of problems are much simpler for colonial governments to deal with than for the Imperial Parliament; there is much more democracy in the air, and there are comparatively few vested interests to attack. It is indeed precisely in Australia, where the old English ideas of landholding were carried out in their entirety, that the rise of a very strong Labour Party has been seen. In other Colonies it is very difficult to see much fundamental distinction between the parties, however readily they may attack the actual administration of the other side. This tact explains the two contrasted sets of phenomena in the case of Canada and the Australian Colonies ; the lack of gruve political differences may manifest itself either in the continuance in office of one party for many years, or in the coustant change of Ministries, none of which can find auy special ground on which to retain hold of the State machinery. In the Commonwealth there have been in the eight years from 1901 no less than five quite distinct Ministries, none of 
which have had any really solid support: the government of Mr. Deakin relied on an alliance between Labour and Protection, the preceding government, that of Mr. Reid, on an alliance between his followers, who were mainly Free Traders, and those of Mr. Deakin, who were Protectionists, against the Labour Party $(f)$. In New South Wales there have been thirty-three Ministries since 18.56, and in Queensland twenty-four since 1859 ; there parties, in 1908 , were almost equally divided between the followers of Mr. Kidston, of Mr. Philp and of Mr. Bowman. There have been since responsible government thirty-nine Ministries in South Australia, thirty-two in Victoria, and twenty-four even in Tasmania. In Canada there were at first far more strictly defined parties, and they shared power under the auspices of Sir John Macdonald and Mr. Mackenzie from 186; up to 1896. Since that date, however, the circumstances have altered. The definite acceptance by the Liberals of the policy of closer relations with the United Kingdom, and the settlement of the troubles as to religious education in Manitoba, have combined to render the dividing lines between the government and the Opposition very slight, nor is there much prospect of their revival in force under the existing régime, as shown by the election of 1908. In the Cape, politics, after a good many vicissitudes, have settled down to a condition, when party differences are certainly weakening, while in Natal there can hardly be said to be any opposition on points of principle between the parties, which are formed from time to time, though they may differ on points of administration. In Newfoundland, to judge from the addresses of the party leaders at the 1908 election, the government and the Opposition vie with each other in efforts at valuable reforms, and

(f) Cf. Times, Nov. 7th, 1908; Age and Argus of that and following dates. Mr. Fisher's gorernment again rests on a coalition. 
differences concern men rather than measures. In New Zealand, during the long Ministry of Mr. Seddon from 1893, there was no serious Opposition in Parliament; there were critics and opponents of particular proposals, but the system of party government may be said to have been in abeyance.

Under these circumstances it is not surprising that in some respects Ministries are rather deficient in coherence and decision of policy, and that the habit of ready obedience to the head of the Ministry does not always obtain $(g)$. It was noted recently, apparently with some surprise, in a leading colonial journal that the Premier of Victoria insisted on his colleagues discussing matters with him and obtaining his approval before they introduced them to the public as being the proposals of the government. The Commonwealth Government in 1907, during the illness of the Premier, found almost open war between the Treasurer and the Minister for Trade and Customs, and the result was the resignation of the former on the 30th July, 1907, which, however, was apparently regarded as on constitutional grounds quite unnecessary. Further, his successor expressed himself as not prepared to carry into effect certain undertakings as to the question of State debts given by the Treasurer to the State Premiers, a condition of affairs hardly conceivable in the United Kingdom (h). At the same time all sorts of coalitions are possible, and in these cases Ministers can hardly be said in any way to form a homogeneous body, and there has been debated frequently of late whether the whole system of party government is not out of place in Australia, and some sort of compromise should not be instituted under which the defeat of one Minister shall not affect the

(g) Anson, Law of the Constilution, II. 1, 124 seq.

(h) Cf. Reports of Brisbane Conference, May, 1907, and of the Melbourne Conference of May, 1908; and see New South Wales Parliamentary Debates, pp. 970 seq., especially p. 991. 
position of any other. Similarly determined attacks were made during 1908 upon one of the colleagues of the Premier of Victoria by papers which professed no desire whatever to see the government out of office. And a good deal of surprise was expressed in the same quarters, because in 1908 Mr. Deakin threatened to resign office, if he could not secure loyal support from the Labour Party $(i)$.

Naturally, where ideas of the responsibility and solidarity of the Cabinet are so feeble, there is no attempt to put in force the doctrine now accepted, perhaps, almost to an extreme degree, in the United Kingdom that a Government defeat is followed by resignation of the Government $(k)$. Of course, if the rule were applied only to small matters there would be some precedent for it in English practice (e.g., the defeats of Mr. Balfour's Administration in 1905), but the disregard of defeat may exteud to large issues without any special notice being taken by a government. For example, the Commonwealth Government allowed itself, in 1907-1908, to be defeated repeatedly in the House of Representatives over the tariff, and that, too, on matters in which the Treasurer had declared himself absolutely determined to make no concessions, without any notice being taken of the fact. 'The sense of party loyalty in these matters is weak, and no government in the Colonies would accept dismissal except on a direct vote of no confidence, or on a crushing defeat at the polls, as in the case of the Mackenzie Government in Canada in 1878 , or of Sir C. Tupper in 1896, or of Mr. Philp's Government in 1908 in Queensland.

As in the case of the Imperial Parliament, the theory of the Government is that an adequate number of Ministers will

(i) In the result the government yielded, and appointed a Royal Commission to inquire into the Post Office. Cf. Parliamentary Debates, 1907-8, No. 79 , \&ic., and for their final defeat, ibid. 1908.

(h) Anson, op. cit. pp. 133 seq. 
sit in the Upper Chamber, but the tendency has undoubtedly been for the Ministry to disregard the claims of the Upper House. In Victoria, during the constitutional crisis as to the powers of the two Houses as regards taxation, there was only one member of the Ministry in the Upper House, and he resigned office, as he was in disagreement with his colleagues on the points at issue, leaving the government without a spokesman in the Council. There are now usually two Ministers in the Council. In New Zealand, since 1876, the government have only kept one Minister in the Council, despite the protests of that body; while in 1877 the Council of South Australia actually deprived the solitary representative of the government in the House of his control over government business, despite the protest of the Governor. In Canada the usual custom is to have at least two members of the Cabinet in the Senate, and in the Commonwealth there is always one Minister, and sometimes two, in the Senate.

There is, however, one peculiarity in colonial Cabinet government which has no precise parallel in the government of England. In each Cabinet there are, as a rule, some members without portfolio or definite duties. In the Commonwealth Cabinet there is the Vice-President of the executive Council, who has no definite office, and also an honoraryMinister; in the States of New Sonth Wales, Victnria, Western Australia, and Queensland $(l)$ there are Ministers without portfolio; while Newfoundland has actually often as many as four Ministers without portfolio, retaining, perhaps, a tradition of the earlier times when an executive Council $(m)$

(l) Arrangements are made by an Act of 1908 of South Australia for an honorary Minister there. See South Australia House of Assembly Debates, 1908, pp. 166, 205.

( $m$ ) Cf. the provision in New Zealand for the possible addition to the executive Council of two Maori members (paid) by an Act of 1873 , Constitution and Government of New Zealand, p. 168. The suggestion (ibid. p. 170, n. 1) that this part is spent is negatived by Act No. 22 of 1908. 
was simply a collection of those persons whom the Governor thought likely to be able to tender valuable advice. On the other hand, of all the South African Colonies only the Cape has found the system of adrantage, and South Australia for some years had a small cabinet of four members, now increased to six, plus the Chief Justice, whose inclusion is decidedly a relic of an older order of things; while in its reduced circumstances since federation the State of Tasmania finds four Ministers enough for its needs. In the case of Canada the appointment of Ministers without portfolio is not in favour; but the curions custom, derired from the English practice, exists of having a Minister who is not of the cabinet, viz., the Solicitor-General; and in New Zealand the AttorneyGeneral may be a member of Parliament or not, and in the executive Council or not ( $n)$.

As is natural, in view of the comparatively small size of the population in the responsible government Colonies, the Ministries are not very large. In the Commonwealth there are nine in all, including the Vice-President of the executive Council and an honorary Minister. In New South Wales and Victoria there are eight, with additional honorary members. In Queensland there are seren, in Western Australia six, and sometimes additional members. In the South African Colonies the Cape, the Orange River Colony, and Natal are content with five each; the Cape having, in addition, two Ministers without portfolio, while the Transvaal has a sixth member. New Zealand has eight members, all with appointments, and Canada fifteen. The departments of government are very variously divided in the different dominions. Canada has departments for trade, public works, finance, railways, customs, inland revenue, marine and fisheries, justice, the post office, the interior, agriculture and

(n) Act No. 22 of 1908, s. 12. 
statistics, militia and defence, and for provincial affairs, viz., the department of the Secretary of State, which also controls the department of printing and stationery. The Prime Minister looks after the Indian department, and is also a member of a finance board, consisting of the Minister of Finance and five Privy Councillors, who consider any point referred to them by Council. New Zealand has departments of the Dominion Secretary, treasury, justice, post and telegraphs, trade and customs, industries and commerce, labour, agriculture, mines, railways and public works, Crown lands, defence, education and marine. The Commonwealth has departments of external affairs (o), the Attorney-General, home affairs, treasury, trade and customs, defence, and the Postmaster-General's department. The Australian States vary in detail considerably; but they have, as a rule, departments of the Chief or Colonial Secretary, the Attorney-General, lands, public works, treasury, education, mines and railways, which agaiu are variously grouped under the Ministers. For example, in New South Wales there are the following Ministers: Premier and Attorney-General, Colonial Secretary and Secretary of Mines, Colonial Treasurer and Minister for Railways, Secretary for Lands, Secretary for Public Works, Minister of Public Instruction, Minister for Agriculture. In South Australia the Premier controls public works and education, the Chief Secretary is Minister of Industry, the Treasurer is also Attorney-General, and the same Minister controls Crown lands, agriculture, and the northern territory, but these duties are in process of re-arrangement on the increase of the Cabinet to six members.

In performing their duties Ministers have no Parliamentary assistance in the shape of Under-Secretaries, \&c. Each State Department is controlled under the Minister by

(o) Harrison Moore, Commonwealth of Australia, p. 231. 
a deputy head, variously styled in the various Colonies and with varying position, but the Minister himself is expected to do a good deal, even of the minor work of his department. This is no doubt a direct survival of the time when the Minister was properly an official who was the directing spirit of the office and not a busy Parliamentary officer. Further, the Governor in some cases takes a very real and active interest in the process of government. The system is, perhaps, seen in its most complete form in. Canada, where the work of government, apart from petty detail, is done by the Cabinet sitting as a whole. Its decisions are embodied with explanatory reasons in minutes, which are then submitted to the Governor-General for approval. On receiving his signature they become Orders in Council, and until they receive that approval are of no effect. The system has been criticized as clumsy, but it seems to have the great advantage of securing the fullest information as to the official acts of the government being given to the Governor-General, and thus enabling him to make such representation as he may in any case deem necessary in inperial interests. A somewhat similar system obtains in Newfoundland, but the Governor actually signs the minutes of the Council in a formal sitting at which he attends. In the Australian States the Governor is ex officio the President of the executive Council, but it is not customary for the Governor to sit in Cabinet, the Premier as a rule acting in his place $(p)$ : the same practice applies to the Commonwealth. In South Africa the usual usage also is that the Governor does not preside at Cabinet meetings, but there are occasional exceptions in case of emergencies, as in

(p) He presides at the Council. The Lieutenant-Governor (acting for the Governor) was present at the Council in New South Wales when the seizure of the wire-netting by the goverument was approved, and the Royal Instructions (see, e.g., clause iv. of those of Victoria of Oct. 29th, 1900, in Harrison Moore, Commonwealth of Australia, p. 380) require him to preside, unless prevented by some necessary or reasonable cause. So in New Zealand. 
the case of the disturbances in Natal in 1906, which naturally call for the more full consultation of the Governor, as the latter represents the Imperial Government, which, through its colonial garrisons, has a special interest in the affairs of the South African Colonies.

The position of the Agent-General is anomalous. It partakes of the nature of a resident Ministry $(q)$, a consul, and a commercial agent, but in practice the latter feature is most prominent. Lately, however, in connection with the re-organisation of the Colonial Office, it has been suggested to make the High Commissioners and Agents-General serve as links between the colonial and Imperial Governments; how far this will be done remains to be seen $(r)$. In any case the office has great value as maintaining in England an officer able to speak with authority for the Dominion or State which he represents.

(q) New Zealand Parl. Papers, 1879, Sess. 2, D. 3 ; Parl. Papers [C. 2594].

(r) Parl. Papers [Cd. 3795]. 


\section{CHAPTER VI.}

\section{THE POWERS AND PRIVILEGES OF DOMINION}

\section{LEGISLATURES.}

Ir has been decided by the Privy Council, in the important cases of Reg. v. Burah (a), Hodge v. The Queen (b), and Powell v. Apollo Candle Co. (c), that colonial legislatures like the legislature of British India are not delegates of the Imperial Parliament, and that the words " peace, order and good government" confer the fullest legislative power possible $(d)$. The legislatures, therefore, are not subject to the rules regarding the exercise of delegated power, and in particular to the regulation that a delegate must not further delegate his power. In the last case the question at issue was, in effect, whether the legislature of New South Wales was competent to delegate to the Governor the duty of fixing in certain cases the rates of customs duties to be levied in the colony, and the decision was in favour of the validity of the act. It is, of course, true that in a certain sense the colonial legislature receives a power which could be exercised by the Imperial Parliament, but that power it is to exercise in a completely free manner, subject only to the doctrine that its enactments must not go beyond the limits fixed for colonial

(a) L. R. 3 App. Cas. 889.

(b) L. R. 9 App. Cas. 117.

(c) L. R. 10 App. Cas. 282.

(d) Riel v. R., L. R. 10 A. C. 675; cf. Lefroy, Legislative Poccer in Canada, p. 214 ; Harrison Moore, Commonvealth of Australia, p. 129.

K, 
legislation in general and for the particular legislature by the act or acts constituting it.

The first of these limitations-would appear to be that the legislature cannot abandon its functions by ceasing to be a colonial legislature and legislating for places beyond the territory of the colony, including in this expression the territorial waters of the colony. (In this respect the colonial legislature stands in a strong contrast to that of the United Kingdom. The latter can legislate, and does legislate, for all British ships on the high seas, and in certain cases it legislates for acts done by British subjects, or even by aliens in places outside the British Dominions.) Nor can it be doubted that, if it chose to extend this practice of extraterritorial legislation, its enactments would receive full effect in all the Courts of the Empire, however contrary to the spirit of international law the provisions might be. But it is otherwise in the Colonies: their own Courts would rule that any attempt to legislate beyond the colonial limits is ultra vires, unless there exists some specific provision of imperial legislation giving their enactments extra-territorial force. This limitation is occasionally expressed more or less clearly in the Constitution Acts of the Colonies; for instance, the Constitution Act of Queensland of 1867 says in precise terms (sect. 2) that the power of legislation is to make laws within the colony of Queensland. This is, however, rather exceptional $(e)$, and the general rule is simply to confer power to legislate for the peace, order and good government of the colony concerned.

(e) It occurs also in the case of Canadian Provinces (British North America Act, 1867, s. 92) and in the case of Victoria (sect. 1 of Constitution (scheduled to 18 \& 19 Vict. c. 55)). See also Ashbury v. Ellis, L. R. [1893] A. C. 339 ; cf. also remarks of the Chief Justice of the Commonwealth in $M^{\prime}$ Kelvey $\mathrm{v}$. Meagher, 4 C. L. R. 268, at pp. 274, 280, and in Merchant Service Guild of Australasia v. Archibald Currie Prop., Ltd., 5 C. L. R. 737, at pp. 742-744; and also D' Emden v. Pedder, 1 C. L. R. 91, at p. 119. 
The nature of this limitation on the colonial power of legislation may be illustrated by a few cases. In 1879 the Supreme Court of New Zealand-following a Victorian precedent of 1875-held that the Foreign Offenders' Apprehension Act, 1863, of that colony was beyond the competence of the colonial legislature, as it involved the detention on the high seas of offenders accused of misdemeanours committed in other colonies whose deportation from New Zealand the Act purported to authorize. In 1888 the Newfoundland Supreme Court held, in Rhodes v. Fainceather, that the laws of the colony did not bind sealers outside territorial waters $(f)$. In the case of Macleod v. Att.-Gen. for New South Wales $(g)$ the Privy Council held that an Act of the legislature of that colony should not be interpreted as authorizing the trial and punishment of a man who committed bigamy outside the territory of New South Wales, as such an interpretation would render the Act ultra vires the colonial legislature. For this reason it was held by the High Court of Ontario (King's Bench Division), in the case of Att.-Gen. for Canada v. Cain and Gilhula, that the Dominion Parliament had no power to deport from Canada over the international frontier a man who had entered Canada in defiance of the law in force prohibiting the entry of aliens engaged under contract to serve in Canada. The Court argued that such deportation entailed the exercise of physical constraint beyond the Dominion territory, and could not be supported. The Canadian Government, however, carried the appeal to the Privy Council, and the Privy Council ruled $(h)$ that the right of expelling aliens existed at international law; that it was

(f) Re Gleich, O. B. \& F. S. C. 39 ; cf. Canadian cases in Lefroy, Legislative Poucer in Canada, pp. 322-333; Newfoundland Lav Reports, 1897, pp. 321 seq., 378 seq.; 1 V. L. R. 274 ; 27 Can. S. C. R. 271.

(g) L. R. [1891] A. C. 455 ; cf. Lefroy, op. cit. pp. 334-338.

(h) L. R. $[1906]$ A. C. $542 ; 22$ T. L. R. 757. 
a right which could properly be exercised by Canada; and that, as the Dominion Parliament had power by the Imperial Act constituting the Dominion to regulate aliens and immigration, the legislature must be deemed to have such power of extra-territorial legislation as was essential to the carrying out of the power of excluding aliens. The case therefore carries us very little on the way to freedom in point of legislation beyond territorial limits. It is especially important to note that it does not touch the case where there is an attempt to put on ship for deportation to England a rejected immigrant, not an alien. The detention on ship board may well be illegal, even if the putting on board is not. In the case of Reg. v. Lesley $(i)$ detention of persons put on board a British ship by a South American Government was held illegal as soon as the ship left territorial waters, but it remains to be seen whether the same doctrine would be applied since the case of the Canadian Act $(k)$.

Much more doubtful is the further conclusion drawn recently from this case by the Chief Justice of New Zealand in deciding a case In re Award of Wellington Cooks and Stevards' Union $(l)$. He there laid down the doctrine that the peace, order and good government of the Dominion involved the power of the colonial legislature to provide for acts done beyond territorial waters, as in the case of the conveyance of prisoners by sea from one point of the coast to another, the ship often being miles beyond the territorial limit. $\mathrm{He}$ argued that the cases cited above merely applied to instances where the people affected were not natives of the colony, and

(i) Bell, C. C. 220.

(k) Cf. also The Ship "North" v. The King, 37 Can. S. C. R. 385, where the Supreme Court held that the doctrine of hot pursuit (Hall, International Law, ed. 5, p. 246) applied to officers seizing a vessel which infringed a colonial law when it had just left Canadian watere.

(l) 26 N. Z. L. R. 394 ; cf. the argument in 5 C. L. R. 739, and Rhodes $\nabla$. Fairweather, Newfoundland Law Reports, 1897, at pp. 333, 334, per Pinsent, J. 
he proceeded to expound the doctrine that the power of colonial legislation extended to legislation for New Zealand ships and people as distinguished from other British subjects and ships. With all respect to Sir Robert Stout it seems quite impossible to follow his reasoning. The Merchant Shipping Act of 1894, s. 735, expressly permits colonial legislatures to regulate shipping registered in the Colonies, but the power is clearly an exceptional one, and, though extraterritorial, is obviously confined to rules regarding shipping matters, and does not extend to allowing a colony to impose its whole code on vessels registered therein beyond territorial waters; when such a power is intended to be given it is bestowed in precise terms, as is the case in sect. 5 of the Commonwealth of Australia Constitution Act, 1900. The dicta in the case of Macleod are too precise to be argued away, and contrast with the express power given by the Imperial Act $(24 \& 25$ Vict. c. 100 , s. 57 ), which allows punishment to be inflicted by English Courts for bigamy committed anywhere by a British subject.

Curiously enough, in evident independence of this judgment, the opinion has been expressed by the Secretary to the Commonwealth Law Department $(m)$ that the power of a colonial legislature was not confined within territorial waters, but extended to everything necessary for the peace, order and good government of the colony. This view approaches much more closely to that of the Privy Council in the case of Cain and Gilhula, and may, indeed, be regarded as correct, provided it be realised that the onus will always lie very heavily on those who endeavour to prove that any colonial Act affecting acts not done within the territory of the colony is within the competence of the colonial legislature $(n)$.

(m) Parl. Papers [Cd. 3023], p. 61.

(n) The doctrine of a continuing Act can be used to ralidate a good deal of otherwise invalid legislation. Cf. Peninsulur \& Uriental Sacigation Co. v. 
The second restriction on the powers of a colonial legislature lies in the rule that any part of its legislation which is in conflict with an Imperial Act or order or regulation made under an Act and applying to the ooleny is invalid. This provision has always been part of the law relating to the Colonies, and in the older eharters and Acts eonstituting colonial legislatures it was customary to enact that all laws passed should not be repugnant to the law of England, and much ingenuity was spent by successive Secretaries of State and their legal advisers in deciding what sort of legislation was repugnant to the law of England. The case where the legislation was repugnant to an imperial Act applicable to the Colonies either by express words or necessary intendment was simple, but there was a vaguely defined sphere of colonial laws which were deemed to be repugnant to the principles of English law. Exactly what these principles were was uncertain; all were agreed that a colonial law permitting torture as a method of trial would be repugnant, but there were disputes how far the abolition of trial by jury was contrary to an essential part of English law, whether martial law was possible, and so forth $(0)$. A good many Acts were disallowed because of their supposed repugnancy to such prineiples, and a really important step was taken when the passing of the Colonial Laws Validity Act of 1865 definitely restricted repugnancy to cases where the provisions of the colonial law conflicted with the provisions of an Imperial Act or regulation made under such an Act applying to the colony $(p)$.

Kingston, L. R. [1903] A. C. 471; and 26 N. Z. L. R. 424 ; Parl. Papers [Cd. 4355], p. 11 .

(o) Stephen, Hist. Crim. Law, ii. 58 ; Lefroy, Legislative Power in Canada, p. 284 , n. 2 .

( $p$ ) The theory once enunciated in Canada (Holmes v. Temple, 2 Cart. 396), but later given up (R. v. College of Physieians and Surgeons of Ontario, 1 Cart. 761), that the Dominion and Provinces had all the legislative power of the Imperial Parliament transferred to them, was, of course, untenuble. Cf. 
The third restriction on the freedom of action of colonial Governments follows directly from the former. It relates to the power of colonial legislatures to alter the Constitution of the colony, and arises in its present form from sect. 5 of the Colonial Laws Validity Act, which enacts that every representative legislature shall have, and be deemed at all times to have had, full power to make laws respecting the Constitution, powers, and procedure of -such-legislature, provided that-such laws shall have been passed in such manner and form as may from time to time be required by any $A$ ct of Parliament, Letters Patent, Order in Couneil, or colonial law for the time being in force in the colony. This specific enactment clears up several doubtful points. It makes it certain that a nonrepresentative legislature is not also a constituent body, and in fact changes in the Constitutions of the Crown Colonies properly so called are never made, save by prerogative legislation in the shape of Orders in Council, Letters Patent, or formerly by Charters of Justice or the Commissions of Governors, all of which instruments are in fact, in part at least, legislative or quasi-legislative Acts by the King in Council. The only exception to this rule is that the Crown may by such an instrument increase for the time being the power of the colonial legislature in order to allow it to legislate for the alteration of its Constitution, as was done in the case of the legislative Council of the Cape in 1850, when Letters Patent of the 23rd May were issued, permitting it to frame a system of representative government. But at the same time it removed all the doubts existing as to the power of representative legislatures, doubts which were not unnatural, as it seemed rather a violent exercise of the legislative power to alter the instrument of legislation.

The effect of the Colonial Laws Validity Act, in this point

Dicey, Law of the Constitution, pp. $101 \mathrm{seq}$. I do not agree with Prof. Harrison Moore (Commonwealth of Australia, pp. 167 seq.). 
simply giving statutory force to the law as understood, was to establish a distinction between all ordinary colonial legislation and constitutional legislation $(q)$ in cases where any imperial or local legislation has established a special procedure in passing Constitutional Acts. In this respect the difference between the imperial and colonial legislatures is marked. No Imperial Parliament can fetter its successors: it may endeavour to enact laws unalterable by any power, but in any subsequent Parliament the law may be simply repealed or altered by contrary legislation. But, on the other hand, though the action of colonial legislatures can be hampered by restrictions as to the passing of constitutional laws, the existing restrictions are not now numerous, save in the cases of the federations of Canada and Australia, and in these cases precisely because they are federations, produced by quasi-treaties between the component States, and therefore not ligbtly to be altered by the federal legislature.

In some dominions, indeed, there are no restrictions at all in force. It is open to the Parliaments to make any alteration in the Constitution of the legislature which it pleases by ordinary law. This is the case in Newfoundland, the Cape of Good Hope, Natal, and apparently, before 1907, in the State of Tasmania $(r)$. In the new Colonies of the Transvaal and the Orange River Colony the power is limited somewhat by the requirement that all Acts amending the Constitution shall be reserved. In the Australian States alterations in the Constitutions require to be passed by absolute majorities in both Houses on the second and third readings in the case

(q) Cf. Cooper v. Commrs. of Income Tax for the State of Queensland, 4 C. L. R. 1304 ; Dicey, Law of the Constitution, pp. 105 seq.

(r) For the history of the rules in the States, cf. Jenkyns, British Rule and Jurisdiction beyond the Seas, App. II. The text gives the position in 1908 . The case of Tasmania was very obscure. 
of Victoria (s), South Australia, and Western Australia $(t)$. The same rule with the modification that two-thirds majorities were required existed in New South Wales, but was repealed in 1857. Similar provisions to those in force in New South Wales were adopted by the Queensland legislature by a local Constitution Act, 31 Vict. No. 38, ss. 9 and 10, but the provision, so far as it referred to the constitution of the Legislative Assembly, was repealed by a colonial Act of 1871. As regards the Council, its provisions remained in force until the political crisis in 1907, when in 1908 an Act, No. 2 of 1908, was passed abolishing all restrictions. In these States all such Acts required reservation and, in some cases, laying before the Imperial Parliament for thirty days before the Royal Assent could be given, but these cumbrous proceedings were swept away by the Australian States Constitution Act, $190 i$, under which reservation is restricted to Bills altering the constitution of the legislature, or the salary of the Governor, or which by any subsequent legislation in the State are required to be reserved. There is further given a definition of the term altering the constitution of the legislature sufficiently narrow to secure that only Bills of real importance shall be reserved; the colonial Parliament is allowed by ordinary unreserved Act-still subject to any requirements of the local law as to absolute majorities-to alter electoral districts, the conditions of the franchise, the qualification of members, proportional representation, and all the multitudinous details of electoral law. On the other hand, a Bill like the Referendum Bill (now Act No. 16 of 1908) of the Queensland Parliament, which purports to refer to the people any matter on which the two Houses are in final

(s) Not very strictly observed. See Jenks, Government of Victoria, pp. 247-249; Victoria Debates, cii. $1420 ; 18$ \& 19 Vict. c. 55 , Sched. \&. 60 ; South Australia Act No. 2 of 1855-1856, 8. 34 .

$(t)$ Cf. for a case, Parliamentary Debates, 1902, p. 2158; and see 53 \& 54 Vict. c. 26, s. 5, and Sched. s. 73. 
disagreement, will properly and necessarily be reserved as indicated by the Premier of Queensland in the discussions of the Bill, and as was actually done by the Governor.

In the case of New Zealand, an Imperial Act $(20 \& 21$ Vict. c. 53) empowers the Parliament to alter or repeal any provisions of the Constitution Act save only those specified, which include the section of the Constitution Act of 1852 declaring the Parliament to be bicameral, and the sections prescribing the form of oath to be taken by members of the Parliament, the election of the Speaker, and the necessity of the Governor's recommendation of money bills. It has been held by no less an authority than Sir H. Jenkyns $(u)$ that this Act remains in force despite the general provisions of the Colonial Laws Validity Act, 1865, and this opinion was adopted in the colonial Parliament in 1907, when a motion for the abolition of the Upper House or its alteration by making it elective was discussed. But it hardly seemed possible to maintain this view, in consideration of the fact that the Act of 1865 is subsequent to that of 1857 , and that its terms are absolute and unlimited, the only restrictions retained being those of the mode of alteration. Further, all Acts amending the constitution of the House of Representatives require to be reserved and to be laid before Parliament.

On the other hand, the powers of the Parliament of Canada to alter the Dominion Constitution are limited. It is true that they are very considerable in extent despite the limitations, for the Parliament can regulate electoral machinery, vary the franchise, increase the number of members, fix judicial salaries, establish certain Courts, alter the salary of the Governor-General, and establish, on conditions which it approves, new provinces. The things it

(u) British Rule and Jurisdiction beyond the Seas, pp. 74, 75; New Zealand Parliamentary Debates, 1907, p. 276. But of. Dicey, Law of the Constitution, p. 106, n. 
cannot do are, however, very important, and include any alteration of the Senate or of the proportional representation of the provinces in the House of Commons. The Canadian provinces, however, have full powers to alter in any way their Constitution, save as respecting the office of LieutenantGovernor, whose unique position in this regard is due to his special position as the representative of Dominion authority in the provinces, his appointment and dismissal lying in the hands of the Dominion Government (x).

In the case of the Australian Commonwealth the power of constitutional alteration is complete in all respects, save only that the mode $(y)$ of alteration is somewhat elaborate. Under sect. 128 of the Constitution any Bill providing for such alteration must first pass in each House of Parliament by an absolute majority, and must, secondly, be submitted not less than two nor more than six months afterwards to the electors in each State, who are qualified to vote for the House of Representatives. If in a majority of States a majority of those voting, and also a majority of all the voters recording their votes, approve the Bill, it is to be presented for the Governor-General's assent. No Bill, however, which affects the proportionate representation of any State in the two Houses, or the minimum number of the representatives of the State in the House of Representatives, or which in any way alters the provisions of the Constitution regarding the State, can become law, unless approved by a majority of the electors voting in that State. Special provisions are made for the occurrence of a deadlock. The only case in which this complicated procedure has been gone through is that of

(x) Munro, Constitution of Canada, pp. 230, 231 ; Lefroy, Legislative Poncer in Canada, pp. 696-700.

(y) Note, however, that in many matters Parliament can decide without need of a constitutional change, e.g., 7, 9, 10, 22, 24, 27, \&c. 
a slight alteration, in 1907, in the time of the election of Senators, which was approved by a majority in every State.

These three constitute all the certain limitations on the legislative power of colonial governments. It has been argued that there are other limitations. Both Professor Harrison Moore (z) and Sir Henry Jenkyns (a) have contemplated the possibility of there being certain subjects which would not be within the competence of the colonial legislature, because they are vitally questions of imperial concern. In another form the argument reappears as the doctrine that there are certain very special prerogatives of the Crown to which the ordinary rule that a colonial legislature can limit the prerogative does not apply. Can, it has been asked, a colony enact that an enemy subject shall not be regarded as such within the colonial waters or territory? Can a colonial legislature provide that a colonial bishopric can only be filled by colonial-born clergymen, or that the Governor should exercise his power of pardon only in accordance with a plebiscite? Or can it in any way alter the relations of the Governor and the legislature? The last question Sir Henry Jenkyns says must obviously be answered in the negative, as wholly beyond the power of a colonial legislature to affect.

There is, therefore, some weight of authority in favour of this view which, as regards the position of the Governor, receives some support from the fact that the Dominion Government in Canada, which stands in the same relation to the Lieutenant-Governors in Canada as the Home Govern-

(z) Journ. Soc. Comp. Leg., 1900, pp. 280 seq. ; Commonwealth of Australia, pp. 10, 255 ; ef. Tully v. The Principal Officers of Her Majesty's Ordnance, 5 U. C. R. 6, per Robinson, C. J.

(a) British Rule and Jurisdiction beyond the Seas, pp. 69 seq. There is also the doctrine of major regalia (Lefroy, Legislative Power in Canada, pp. 178186), which is, in my opinion, quite wrong, and has no sanction whatever from the Judicial Committee. Cf. [1892] A. C. 441 ; [1907] A. C. 179, 519. 
ment to colonial Governors, cannot alter the conditions regarding the tenure of office of these officers, nor can the provinces themselves do so. But it is submitted that in all the cases specified the colonial legislature has full legal power to act. All the matters fall within the category, peace, order and good government, however foolish the actual exercise of the power might be. Further, the imperial control by veto or disallowance is adequate to prevent any harm arising from the existence of a power which might be in theory misused. The question of the position of the Governor cannot be said to be beyond the consideration of the Parliaments of the Dominions, when as a matter of fact the legislatures are constantly imposing new duties on the Governor in Council. Or again, it is impossible to believe that a colonial Act duly passed and not disallowed, which made the position of Governor elective, would be invalid. Tasmania in 1853 contemplated making a Governor removable by a two-thirds majority vote. Certainly no invalidity would attach to any rules regarding the exercise of the prerogative of pardon (b).

There is, however, a certain element of truth in this doctrine of a limitation of the powers of colonial legislatures, arising from the mere fact that they are what their name signifies, legislatures for a colony. This limitation should, perhaps, be specified as a prohibition to abolish either the legislature or the state of being a colony. Or to put it more precisely, the colonial legislature can neither give up its existence as a legislature, nor sever the connection between it and the mother country, so that the dream of pacific settlement in the case of a secession from the Empire by a colonial Act duly allowed is meaningless. The latter proposition it

(b) So, in Canada, the Lieutenant-Governors can pardon under statute, e.g., Outario Revised Statutes, c. 13, though the only Royal delegation is to the Governor-General : 23 Can. S. C. R. 468; below, Chap. XI.; Canada Sess. Papers, 1869, No. 16 ; Ontario Sess. Papers, 18s8, No. 37 ; above, p. 32. 
is fortunately not possible to illustrate, but the former can be illustrated by the precedent of Jamaica in 1866, when after the insurrection the legislature decided to abandon its existence and to leave it to the Crown to create a new Constitution, and it was decided that the surrender of the Constitution was beyond the powers of the colonial legislature, and accordingly the colonial Act was supplemented by an Imperial Act $(c)$ authorising the Crown to accept the surrender and make new provision for the government of the colony. Similarly in 1876, when the government of the Windward Islands was reconstituted, the legislatures of St. Vincent and Grenada extinguished themselves, and their extinction was authorised by an Imperial Act $(d)$. With these cases may be contrasted the fact that the legislature of the Virgin Islands has by a series of enactments managed to reduce itself to the Governor of the Leeward Islands (e), and the legislature of British Honduras $(f)$ has voluntarily deprived itself of its elective character and become a nominated body, with, however, a majority of unofficial members. But in both cases the legislature remains, though in the former it is a mere shadow of itself. This principle was asserted of the Indian legislature by the Privy Council in the case R. v. Burah $(g)$.

If a colonial legislature cannot extinguish itself $(h)$, clearly it cannot abolish the position of the Governor as the representative of the Crown. It is indeed still regarded as quite improper for the colonial legislatures to make any law affecting the arrangements for the performance of the Governor's duties, when he is on leave of absence or is away

(c) $29 \& 30$ Vict. c. 12 .

(d) $39 \& 40$ Vict. c. 47 .

(e) Ordinance No. 1 of 1902, and Leewards Act No. 16 of 1902.

(f) Act of 1870 and Ordinance No. 4 of 1892.

(g) L. R. 3 App. Cas. 889, at p. 905.

(h) Contra, Harrison Moore, Commonwealth of Australia, p. 321 ; Darey, Canada Sess. Papers, 1884, No, 30, p. 10. 
from headquarters. Some doubt was expressed by the Chief Justice of South Australia as to the powers of a Deputy-Governor, for whose appointment there was no further warrant than the Royal Letters Patent creating the office of Governor, and in accordance with his suggestion a Bill was actually introduced into the legislature to provide that a Deputy-Governor should possess all the powers and authority vested in the Governor. But exception was promptly taken in the Parliament to the Bill, on the ground that it was an interference with the prerogative, and in particular contradicted the Letters Patent, which contemplated the exercise by the Deputy-Governor of so much only of the authority of the Governor as the latter might choose to entrust to him. The Bill was, accordingly, dropped on this ground; had it not been dropped, it would certainly have been reserved for the significance of the pleasure of the Crown, nor is there any probability that the required assent would have been given $(i)$. But it is singularly characteristic of the happy-go-lucky character of the Constitution Acts of the Colonies as regards the executive power that in theory such a Bill, which is clearly within the legislative competence of the colonial legislature, however undesirable its clauses, is not expressly required to be reserved. In all such cases the proper mode of procedure is by Letters Patent, like those of 17th July, 1905, in the case of Newfoundland providing for the appointment of a deputy, in the temporary absence of the Governor-General.

All Dominion Parliaments have, of course, full power under the Constitutions to regulate their own procedure,

(i) Cf. South Anstralia Legislatire Council Debates, 1906, Sess. 1, p. 141; House of Assembly Debates, 1906, Sess. 1, pp. 190 seq. The Bill passed the House of Assembly, but not the Legislatire Council, and in the Council, on Oct. 1st, 1908, a motion for the extension of the Governor's term of service was withdrawn, as not quite constitutional, by the mover. 
which is in all cases based on and a close imitation of that of the British Parliament: in the Cape on 24th March, 1904, the Speaker went so far as to put the question on his own authority, when a debate had become hopelessly protracted, in imitation of the famous action in 1881 of $\mathrm{Mr}$. Speaker Brand. The most novel feature is the adoption in certain cases of a time limit for speeches $(j)$. Reference has already been made to the formal rule that all money Bills shall be recommended by the Crown. But in all probability no Court can inquire into such irregularities of procedure when the procedure is fixed merely by rules of the Parliament $(k)$; it would be different in cases where the Constitution itself required certain procedure, as for example in Victoria, South Australia, and Western Australia, where absolute majorities are required for passing certain constitutional Bills.

The question of the privileges of Parliament has at last been settled by colonial Acts. In the absence of such legislation there is no doubt that a colonial legislature is in no better position than any body which debates: it is entitled to exclude persons who are actually making a disturbance, but the power of committal, in the sense in which it is possessed by the House of Commons, does not belong to the colonial Houses. It was decided in the case of Kielley v. Carson ( $l$ ) that the Assembly of Newfoundland had no power to order an arrest on a complaint of contempt committed out of doors, no such privilege being conferred on it by the Crown (even if the Crown had power to do so), and no such authority being required for the proper performance of the duties of the Assembly. On the same principle, it was held in the case of Fenton $\nabla$. Hampton $(m)$ that the Legislative

(j) Parl. Papers, H. C. 301, 1908.

(k) Cf. Harrison Moore, Commonwealth of Australia, p. $176 ; 17$ V. L. R. 296.

(l) 4 Moo. P. C. 63.

(m) 11 Moo. P. C. 347 . 
Council of Van Diemen's Land had no authority to commit the Comptroller-General of Convicts for a refusal to appear before a Commission as to the alleged ill-management of the convicts on the island. In both cases the powers of a colonial legislature were expressly distinguished from those possessed by Parliament in England in virtue of the lex et consuetudo Parliamenti. In yet other cases (Doyle v. Falconer (n), Barton v. Taylor (o)) it has been decided that, without parliamentary sanction, a colonial legislature cannot imprison for even a contempt committed in the House, though it can expel for the time the offender, but not suspend him indefinitely.

On the other hand, the Constitution Acts of the Dominions nearly always give the power to the legislature to pass laws conferring on the members of the Houses and the Houses the same privileges as those enjoyed by the House of Commons, or any less privileges. The nature of the powers so conferred was discussed in two cases which arose out of the exercise, in 1857, by Victoria, of the power in question. It was decided in the case of Dill v. Murphy $(p)$ that the Legislative Assembly could commit the appellant in that case for publishing a libel on a member of Parliament. In the case of the Speaker of the Legislative Assembly of Victoria v. Glass $(q)$ this decision was carried to the point of affirming as law in Victoria the supreme example of the power of committal in England, viz., the right of the Commons to commit for contempt without specifying in any way what the contempt consists of.

The question, however, remains in those Colonies, where the power of defining the privileges is not formally given,
(i) L. R. 1 P. C. 328.
(o) L. R. 11 App. Cas. 197.
(p) 1 Moo. P. C. (N. S.) 487.
(q) L. R. 3 P. C. 560.

$\mathbf{K}$. 
but at most power to make standing orders for the conduct of business $(r)$, how far it may be exercised. In 1859 the question was answered in Tasmania by the Parliament passing a Bill to confer on itself privileges similar to those of the House of Commons, and the Act was assented to and not disallowed. But when this precedent was followed by Ontario, in 1868-9, the Act was disallowed by the GovernorGeneral in Council, after reference to the law officers of the Crown in England, as being ultra vires. However, an Act of Quebec to very much the same effect was allowed to remain unchallenged in 1870 ; but, again, a Manitoba Act which conferred on the legislature the privileges of the Dominion Parliament was disallowed in 1874. It was held, however, by the appeal side of the Court of Queen's Bench in Quebec, in the case of Ex parte Dansereau (s), that the Quebeo Act of 1870 was valid in so far as it authorized the summoning of witnesses before a committee. The grounds alleged were various, but there were at least two reasons for the power being held to exist, either in that it was a power essential to the performance of the duties of a Parliament, or that the Act was an amendment of the provisions of the Constitution of the province under sect. 92 (1) of the British North America Act, 1867. In 1876 the case of Landers $\mathbf{v}$. Wooducorth $(t)$ raised the question of the power of the Nova Scotia legislature to order the removal of a member from the House until he should see fit to apologise for what was considered obstructive conduct. The Supreme Court of Canada in 1878 decided that the power to insist on an apology did not exist, but intimated that it could be taken by provincial Act ; and, indeed, in the meantime the Nova Scotia legislature

(r) See Harnett v. Crick, L. R. [1908]. A. C. 470; cf. Toohey v. Melville, 13 N. S. W. L. R. 132 ; Norton v. Crick, 15 N. S. W. L. R. 172.

(8) 2 Cart. 165.

(t) 2 Cart. 220. 
had passed such an Act. In that year, also, the legislatures of Ontario and Manitoba passed Acts declaratory of the privileges of Parliament; and these Acts were allowed to remain in operation, as was an Act of British Columbia in 1871. It must, therefore, be taken as established that the provincial legislatures have full power to define their own privileges $(u)$.

A rather curious question presents itself as to the power of a provincial or Dominion legislature, which is not expressly empowered to confer on its members privileges not exceeding those enjoyed by the House of Commons, to confer upon itself privileges in excess of those conferred by law and custom on that House. It does not appear to be possible to place any legal limits on the power to confer privileges where no limitation by the Constitution exists; but in the Canadian provinces any Act clearly exceeding these privileges would probably be disallowed by the Governor-General in Council, as it would be rather absurd for the provincial Parliaments to have greater powers than the Parliament of the Dominion, or it might be held ultra vires by infringing the sole right of the Dominion to control criminal law. Similarly, in any Dominion, the power of disallowance would probably be used to prevent, say, a Parliament conferring upon itself the right to imprison for contempt beyond the session, or to inflict large fines, and so forth.

In these cases where the Constitution limits the privileges by the precedent of the Imperial House of Commons, there

(u) Munro, Constitution of Canada, pp. 66-68. See also Ficlding v. Thomas (on appeal from Nova Scotia), L. R. [1896] A. C. 600, which bases the right on the power of constitutional alteration; and Lefroy, Legislative Power in Canada, pp. 741-750. No argument as to the power of the Parliament to legislate in the case of a colony can be derived (ans by Harrison Moore, Commonecalth of Australia, p. 83) from that case, as the Provinces have no eriminal legislative power, and their power to constitute criminal Courts does not allow them to create a Court with a new eriminal jurisdiction. See at pp. 612,613 . 
have been disallowed Acts passing these limits. So, in 1873, a Canadian Act was disallowed because it conferred excessive powers as to the examination of witnesses on oath by the Senate, and Commons, and by committees, and it was at the same time pointed out that an Act of 1868 was inoperative, as being repugnant to the British North America Act. The special difficulties were removed by an alteration in the Imperial Act by a new Act of 1875 , but the principle of the restriction still remains in force. On the other hand, it must be remembered that the restriction is only a small one, and that the force of its provisions merely prevents the conferring of too extensive freedom from the usual rules of law upon the members of Parliament, or the exercise of too wide a power of committal for contempt.

The privileges actually claimed are always pretty much the same. 'They include freedom from arrest in civil matters during the session, and in some cases for some time before and after, varying from twenty to forty days as the maximum. Free speech is also claimed, and freedom from serving on juries, while for the better performance of its duties the Parliaments claim the power of summoning witnesses and punishing members and others for breach of the privileges of the House by imprisonment during part or the whole of the session.

It should be noted that of the individual Colonies no provision is contained as to privileges in the Constitutions of the Cape or Newfoundland, but in the case of the Cape, the omission is made good by Act No. 1 of 1854, and of Newfoundland by c. 2, s. 10 , of the Consolidated Statutes. Similarly, in some of the earlier State Constitutions of Australia, such as those of New South Wales (x), Queensland

(x) Hence the case of Barton v. Taylor, L. R. 11 App. Cas. 197, deciding that the Assembly could not suspend a member beyond a sitting. The 
and Tasmania, no mention is made of the matter beyond empowering legislation for standing orders, whereas in the case of Western Australia (y), the usual clause is inserted. In the case of the Commonwealth, the privileges are to be defined by the Parliament, but they are at once to be those of the Commons in England, and are in no way restricted for the future. A committee is now considering the question of privilege, and an Act has been passed in 1908 to protect parliamentary publications. In New Zealand both Houses have the same privileges as the House of Commons on January 1st, $1865(\approx)$. In Natal the Parliament is to have the power to claim privileges not exceeding the privileges of the House of Commons in virtue of the Constitution Act $(a)$, and the Transvaal $(b)$ and Orange River Colony $(c)$ bave power to define their privileges so as not to exceed those of that House.

Constitution Act, 1902 (like the Act 18 \& 19 Vict. c. 54), does not mention privileges. Cf. p. 98, note $(n)$.

(y) See 53 \& 54 Vict. c. 26 , sched., s. 36 . So in Victoria. See sect. 35 of Constitution, scheduled to Imperial Act 18 \& 19 Vict. c. 55 ; Act No. 1075, s. 10 ; Harrison Moore, Commonventth of Australia, p. 114; in Sonth Australia, Act No. 2 of $1855-56$, s. 35. For the powers in Queensland, see Act 25 Vict. No. 7, and Act 31 Vict. No. 38.

(z) New Zeuland Act, 1865, No. 13, 8. 4 ; 1908, No. 101, s. 242.

(a) No. 14 of 1893, 8. 42, exercised by Act No. 27 of 1895.

(b) Letters Patent, Dec. 6th, 1906, s. 33; Power and Privileges of Parliament Act, 1907. Cf. Cape Act No. 13 of 1883.

(c) Letters Patent, June 5th, 1907, s. 35. 


\section{CHAPTER VII.}

\section{RELATIONS BETWEEN THE HOUSES OF THE LEGISLATURE.}

As a result of historical circumstances every responsible government colony at the present day has a bicameral legislature, and it is only in the provinces of Canada that the custom of unicameral legislatures has been adopted. It was originally considered that a colonial Constitution in a settled colony could only be based on the model of that in force in the mother country, and it is significant of the prevalence of the idea that, as late as 1791, the Imperial Act for the government of the two Canadas contemplated the possibility of the Crown attaching titles of honour to the tenure of seats in the Upper House $(a)$. These titles would have been hereditary, and would have been accompanied by seats in the legislative Councils, so that there might have arisen a colonial nobility in possession of a permanent share in legislation. Fortunately this anomaly was averted, and the Crown never exercised the reserved power.

The influence of the doctrine of the necessity of having two Houses was seen in the advice given in 1850 by the Committee of the Privy Council which advised on the creation of representative government in the Cape of Good Hope, and in the Act of 1850 which encouraged the Aus-

(a) 31 Geo. 3, c. 31 , s. 6 ; ef. Shortt \& Doughty, Documents relating to Const. Hist. Canada, p. 665 . It was contemplated to give the members, to begin with, provincial baronetcies, with possibilities of higher things. No later Act contemplates this. It was discussed in Tasmania, and ridiculed, in the period 1850-54. See Acts, fc. of the Legislative Council, 1879, pp. $63 \mathrm{seq}$. 
tralian legislatures to set up bicameral chambers in place of the composite bodies, partly elective and partly nominee, which were provided for in the Act of $1842(b)$. When the Constitution of Natal was under consideration in the years before 1893, there was considerable doubt in the colony on the part of those who were asking for responsible government whether it was wise or desirable to create two chambers in the legislature, but there was given a pretty clear intimation of the opinion of the Secretary of State that it would lead to grave doubt to attempt to set up a legislature on other than the traditional basis. The precedent of Natal was followed in the case of the Transvaal and the Orange River Colony in 1906 and 1907, while naturally Western Australia followed the lead of all the Australian Colonies in 1890. Of the North American Colonies the older ones possessed from their beginnings bicameral legislatures, but the provinces have gradually discarded them. Ontario was given a single chamber by the Federation Act of 1867, that of Manitoba disappeared in 1876, that of New Brunswick in 1891, and that of Prince Edward Island in 1893. Quebec and Nova Scotia still retain nominee Councils of twenty-four and twenty-one members, in either case appointed for life by the Lieutenant-Governors, but this is little more than a survival. It is characteristic that in the new provinces of Canada created in 1905 by the Dominion Parliament there are constituted only single chambers.

There exists one broad distinction between the various forms of legislature, between those in which the Upper House is bicameral and in which it is nominated. The former rule applies to Victoria, Tasmania, Western Australia and South Australia, to the Cape of Good Hope and the Commonwealth of Australia; the latter rule applies to the Dominion 
Senate $(b)$, the legislative Councils of New South Wales, Queensland, New Zealand, Newfoundland, Natal and, as has been already mentioned, the two Canadian provinees, which still preserve the two-House system. In the case of the elective Upper Houses the general rule, to which the Commonwealth offers the only but most important exception, is that the franchise for the Upper House is higher than that for the Lower House. Further, in the Cape and Victoria, there is a property qualification for members of the legislative Council, and in all cases save that of the Commonwealth of Australia the legislative councillor is required to be thirty years of age $(c)$. The natural result of these regulations is that the Upper House is steadily conservative in tendency as compared with the Lower House. On the other hand the result in the case of the Commonwealth is precisely the reverse. In that ease the Senate and House of Representatives are elected under the Franchise Act, 1902, on precisely the same qualifications in the electorate and the members alike, with the result that the Senate is markedly more democratic in tone than the House.

As these legislative Councils are elective, though not subject to dissolution, there would seem no reason why they should not be deemed to have precisely co-ordinate powers inlegislative matters. This is not, however, the case as regards money Bills, the practice of the Imperial Parliament having been grafted upon the Parliaments. Thus the Constitution Act of Victoria of 1855, s. 56, expressly provides that money Bills must be recommended to the Lower House by the Governor, and that taxation and appropriation Bills must originate in

(b) The Constitution Act of 1840 (3\& 4 Vict.c. 35$)$ provided for a nominee body chosen for life by the Crown; under authority of 17 \& 18 Vict. c. 118 , half of the Council was made elective for eight years, but this proved unsatisfactory, and in the Act of 1867 the old principle was adopted.

(c) For the details, which are from time to time altered in a more liberal sense, see Colonial Office List. 
the Legislative Assembly, while such Bills may be rejected but not altered by the Council. This plan worked badly, and a local Act of 1903 has empowered the Council to suggest amendments $(d)$, which process, save in name, cannot be distinguished from amendment, though the alteration of nomenclature may be said to save the principle of the supremacy of the Commons, however meaningless such supremacy may he when the two Houses have each a mandate from the people. In the case of South Australia the Constitution Act No. 2 of $1855-1856$ only provided that neither House could pass money Bills or votes for any purpose not recommended to the House of Assembly by the Governor. A compact of $185 \tilde{i}$ between the Houses agreed that the Council could make suggestions for money Bills, and could reject, amend or assent to Bills sent up to them, but were not to reject the ordinary appropriation Bills for yearly expenditure, though they could criticise them. In Western Australia the Constitution Act of 1890 only provided that the Governor's recommendation of money votes was essential, and that taxation and appropriation Bills must originate in the Assembly. By an amending Act of 1899 , it is provided that the Council may freely return any money Bill sent up to it, requesting alteration, but it has been ruled that the Council cannot insist on a request rejected by the Lower House $(e)$. The rule in Tasmania remains as it originally was in Western Australia, and the Upper House can by constitutional usage reject but not alter a money Bill. In the Cape, on the other hand, though the usual provisions exist requiring the assent of the Governor to any appropria-

(d) On the distinction, cf. Western Australia Parliamentary Debates, 1906, p. 1125, and see Act No. 1864, s. 30 .

(e) Western Anstralia Parliamentary Debates, 1906, p. 3020: for Tasmania, see Act 17 \& 18 Vict. c. 17 , s. 33 : for Cape, Act No. 2 of 1852, 8. 85 (confirmed by Order in Council, Aug. 9th, 1852); for Commonwealth, Constitution ss. 53-55 ; Harrison Moore, Commonucealth of Australia, pp. 119 seq. 
tion proposed in Parliament, and though elaborate provision is made to secure that all appropriation and taxation Acts shall be initiated in the Lower House, the Council is freely permitted to amend money Bills. It should, however, be noticed that the power to amend, coupled with the proviso that any increase of the burdens of the people must be recommended by the Governor, forbids the Councils to do other than diminish the burdens of the country; they cannot suggest increases. In the case of the Commonwealth of Australia, while provision is duly made for the recommendation of the Governor-General and for the initiation of money Bills in the House of Representatives, the Senate is not allowed to recommend but only to suggest amendments in Bills. This power, for all practical purposes, is as good as the power to amend, and indeed it has just been discovered to have a signal advantage over the power to amend proper. For Sir John Forrest, ou the return to the House of Representatives of the Tariff Bill in 1908 in many points with suggested increases of the tariff proposed by the House of Representatives, raised the question whether in this way the Senate was not really making of no account the prohibition of any money votes being made without the approval of the Governor-General; but the Speaker, to whom the appeal was addressed, as the custodian of the privileges of the House, ruled that the Senate had not amended but had merely suggested increases, and that their action did not therefore contravene the established principle. Further, the Senate can insist on suggesting amendments as often as they like. The result, therefore, is that the Senate of the Australian Commonwealth exercises almost equal powers with the House of Representatives as far as money Bills are concerned, though such Bills still cannot originate in that chamber $(f)$. More-

(f) Commonwealth Parliamentary Debates, 1907-8, pp. 10484 (cf. 1902, 14889,.14892, 14918, 15676 ; Parl. Papers, 1905, i. 385) and 11424 seq. 
over, tacking is prohibited, and appropriation Bills are defined so as to exclude new Bills imposing fines for services and licenses.

As in the case of money Bills, still, of course, more decidedly in all other matters, the Upper Chamber has asserted its claim to equal consideration with the Lower. In a sense, indeed, the Upper House is inferior; partly tradition and still more the lack of financial initiation have produced the result that the government of the day is controlled by the wishes of the Lower House, not of the Upper. But the Upper House exercises a quasi-independent function of criticism and objection. It was estimated by the committee which drafted the Constitution for Tasmania that the action of the Lower House would always be conceived in the interests of the people, but that there would be the danger of hasty and too democratic legislation, which the wisdom of the Upper House with its decided property franchise would check $(g)$.

It is, perhaps, in Victoria that the conflicts between the Council and the Assembly have been most prolonged and carried out with most bitterness on either side. Under the tenure of office of Sir Charles Darling the first struggle came to a head $(h)$. The Assembly decided to try to introduce a new Customs tariff, and to overcome the known resistance of a majority of the Council to the policy of protection embodied in the tariff, tacked it on to the Appropriation Act. The Council being unable to amend, decided to lay the Bill aside, and the Assembly thereupon induced the Governor to pernit the levy of duties merely on the strength of a resolution of

(cf. 11678), contain the formal assertion of the position of the House of Representatives. Contrast Victoria Act No. 1864, s. 30.

(g) See Acts, fe. of the Legislatice Council, 1879, pp. 63 seq. The Commonwealth Senate has, by law, equal powers with the Lower House.

(h) Seo Parl. Papers [C. 2173], pp. 103-113; House of Commons I'apers, 1866, L. 695 seq. 
the Assembly, to borrow money without a law, and to pay official salaries without an Appropriation Act. For these extraordinary breaches of his duty the Governor was severely rebuked by Mr. Cardwell, then Secretary of State, in despatches of the 27th November, 186.5, and the 26th February, 1866, in which it was pointed out that it was no part of the duty of a Governor to act as a partizan of one branch of the legislature. Finally the Governor was recalled, but the two Houses reconciled their differences by a policy of mutual concession.

But the truce was of brief duration, and again the cause of offending was a matter of finance. The Assembly, who had found so keen a partizan in Sir George Darling, was anxious to provide him with some recompense for the loss of official position caused by the recall, and roted a sum of 20,000l. as a gratuity to Lady Darling. To secure its passage through the Council the item was tacked on to an Appropriation Bill, and the Bill was thrown out by the Council. The matter threatened a complete deadlock, when the intimation by Sir George Darling that he would prefer the grant to be dropped settled the difficulty; during which the new Governor, Sir J. Manners Sutton, had done all in his power to promote a settlement, while strictly refraining from any action which was of an illegal character. In 1877, however, the dispute burst forth in much greater activity (i). The immediate cause was the opposition of the Council to the practice of paying members, and their refusal to pass an Appropriation Bill including an item of this kind. But the matter was fought more as a matter of principle, and in order definitely to decide in whose hands lay the constitutional power of the purse. The Council did not, indeed, ever assert any claim to amend Appropriation Acts, but they held that they were entitled to discuss and amend important questions of prin-

(i) Parl. Papess [C. 1985], [C. 2173]. 
ciple in regard to public policy, instead of being compelled to accept new ideas in the form of illegitimate addenda to Appropriation Bills. The complaint was, in truth, not unjustified, and was in concurrence with the actual practice in the United Kingdom, where any new legislative principle is normally introduced in Bill form and not merely tacked on to an Appropriation Act, as in the recent cases of the Licensing and Old Age Pension Bills of 1908, both of which measures might, under the Victorian system as claimed in 1877, have been dealt with as parts of an Appropriation Act $(k)$. The Ministry, secure in their control over the country, asked the Governor to issue warrants for payments without the approval of Parliament. He did so, but only on assurances that the practice was legal, and even then he referred the matter for the decision of the home law officers. The government made an indignant protest against the principle of the Governor hesitating to accept their advice as final on such matters of local interest and local law. But the Secretary of State entirely declined to accept this view, and in a despatch of the ôth July, $1878(l)$, laid down the rule that, in a matter where the law was doubtful, the Governor must ask the advice of the law officers of the colony, as such, not as Ministers ( $m$ ), and if a certificate of legality could not be given, must consider whether the emergency was such that he could take the responsibility of acceptiug ministerial advice, or whether he must decline to act, even at the risk of their tendering their resiguations. The law officers in England advised that certain payments, those incurred in the collection, management, and receipt of the revenue, were legal under sect. 45 of the Constitution Act of 1855 without the consent of Parliament, but that moneys merely voted in

(k) Cf. Anson, Law of the Constitution, I. 267, 268.

(l) Parl. Papers [C. 2173], p. 81.

(m) Ibid. [C. 1982], p. 41; and Colonial Regulatione, No. 182 (ed. 1908). 


\section{RESPONSIBLE GOVERNMENT IN THE DOMINIONS.}

Committee of Supply could not be used, unless they had been specifically appropriated by an Act of the Parliament $(n)$. In another point, a serious difference of opinion developed itself between the Governor and the Secretary of State. Sir George Bowen consented to the dismissal of a considerable number of public servants in order to make the funds available last longer, and to the action of his government in reinstating only a certain number of them when funds were voted. He did so because he was satisfied that a refusal to act would only lead to a resignation by his Ministers and that no other Ministry could be hoped for. Not in any case did he consent to dismissals which were illegal, but merely allowed the government to exercise the undoubted power of the Crown to terminate the employ. ment of its officers. Nevertheless, the Secretary of State in a despatch of the '25th August, $1878(0)$, distinctly disapproved of his action, and expressed the opinion that he should have refused to violate the principle that the Civil Service should on no account be allowed to become a pawn in the political game. If the Governor had refused to concur in the dismissal very possibly the government would have dropped the project; while, even had they: resigned in consequence of his action, and had been upheld by the country, the Governor would have been justified in declining to accept any less proof of the country's approval of so drastic steps. The Governor answered the strictures of the Secretary of State by laying great stress on the commanding position of his Ministers, but the Secretary of State was unable to alter the opinion already expressed, though his general judgment of his action was favourable to the Governor $(p)$. The deadlock remained, and the Government

(n) Parl. Papers [C. 2173], p. 97 ; cf. pp. 124 seq.

(o) Ibrd.p. 99 .

(p) Ibid. [C. 2217], pp. 42-48, 75, 76. 
proposed that all money Bills, if not accepted by the Council within a month after reaching the Upper House, should be deemed to have been passed, and should be presented to the Governor for the Royal Assent; while all other Bills, if passed at two consecutive Sessions by the Assembly, should become law, unless, at the request of the Council, the Bills were referred to a plebiscite. These proposals were, of course, rejected by the Council, and Mr. Berry, the Premier, proceeded to England to invite the interposition of the Imperial Government to alter the Constitution Act, so as to permit of alteration of the colonial Constitution by Bills passed at two consecutive Sessions of the Parliament by the Assembly with a general election intervening, despite the refusal of the Council to concur $(q)$. The Secretary of State, in a despatch of the 3rd May, 18i9 (r), declined to accede to this proposal, and intimated clearly that in his opinion both Houses had failed to observe their constitutional rights. $\mathrm{He}$ insisted on the difficulties of defining by law the exact character of the position, and suggested that it was essential that both Houses should follow the spirit of the English practice, under which the Upper House would not interfere in financial matters proper, but the Lower House would not tack on to Bills of Supply sections really foreign in character and introducing new principles. The result of the mission was thus, on the whole, fruitless, and accordingly the difficulty was only removed by a change of Ministry. The question at issue was thus solved rather in favour of the Council, and in 1903 the formal right of suggesting alterations in money Bills was accorded to the Council, and provision was made for a dissolution of the Council in case of a deadlock. The Governor bad suggested that the House should be made nominee, but the suggestion was not accepted as satisfactory

(q) Ibid. pp. 1-19, 35, \&c.

(r) Ibid. [C. 2339], p. 20. 
by the Secretary of State, and feeling in the Council was naturally dead against any such proposal.

The case of the South Australian Parliament has, in some respects, been no less interesting $(s)$. As early as 1864 the Council complained of the action of the Assembly in trying to ignore the Council in money matters, and the Governor then endorsed the action of the Council, and expressed the intention of requiring as authority for the sanction of the issue of funds the consent of the Parliament conveyed in the form of Bills duly assented to, instead of mere resolutions of the Assembly. In 1877 the question came to a head in a matter of the construction of new Parliament buildings without the approval of the Council. The government declined to give way to the Council, which then proceeded to the extraordinary step of declining to permit the Minister in charge of the government business in the Council to proceed with business, superseding him by a private member. This step the Governor strongly disapproved, but he induced the government to stop the progress of the buildings pending further discussion. The Opposition then carried a motion of censure on the government, there being an equality of votes, but the Speaker, on principle, voting against the government, and Ministers resigned. Their successors with some difficulty secured the passage through the Council of a Bill for the execution of the necessary works, and the crisis terminated for the time. But the situation was deemed unsatisfactory, and in 1881, by Act No. 236, a means of deciding in the case of deadlocks was devised. As it now stands, under Act No. 7 i9 of 1901, when a Bill has twice been passed by the Assembly and twice rejected, or amended in a way which the Assembly will not accept, by the Council, the Governor may either dissolve both Houses or may call up by election one, or

(s) Cf. Harrison Moore, Commonwealth of Australia, pp. 120 seq. 
not more than two members of the legislative Council in each of the electoral districts. The power is only permissive, and not mandatory, and it is neither very easily to be exercised nor very likely to be conclusive, as it involves a general election between the two readings of the Bill in the Assembly, and at the end merely gives the people a chance of influencing the electorate for the Council. The peculiarly effective nature of the opposition which the Council can offer has just been seen in regard to the question of the broadening of the somewhat high franchise for the Upper Chamber, which at present makes the number of voters for the Assembly about four times as large as that for the Council. The fight came to a head in 1906, when the Premier, Mr. Price, applied to the Governor for a dissolution preparatory to an attack on the Council by forcing, after the general election, the Constitution Amendment Bill through the Assembly, and on the rejection of the Bill by the Council procuring from the Governor a penal dissolution of the Council. The Governor, feeling that it was his duty, if possible, to avoid the loss of time and waste of public money arising out of a new general election, when the Parliament was still young, declined the request of the Premier $(t)$, and asked the Leader of the Opposition to form, if possible, a government, but on his failing to do so he recalled Mr. Price and gave him the dissolution for which he had asked. Luckily the result of the election was decidedly in favour of the Premier, and further proceedings were, for the time, averted by a compromise under which the franchise, if not spread so wide as desired by the government, was considerably expanded, both parties thus retiring with honour from the conflict, in which much public time had been expended (u).

(t) South Australia House of Assembly Debates, 1906, Sess. 2, pp. 524 seg.

(u) The Act of 1901 has been amended in 1908 so as to render the referendum more effective by increasing to nine the number of additional members. In

K. 


\section{RESPONSIBLE GOVERNMENT IN THE DOMINIONS.}

In Tasmania the Council has asserted and maintained a wide control, and even a right of amendment over money Bills. In 1879 it insisted on the Supply voted being restricted to six months, so as to compel Ministers to bring forward the proposals which were urgently required for the balancing of revenue and expenditure. The Assembly asked only that Supply should be granted for nine months, but eventually compromised on eight, and Ministers promised to bring in their further legislative proposals for rectifying the financial position of the government without delay. The position thus claimed by the Council has never been lost, and the Council remains a controlling factor in all political legislation. It is not prepared to assent to any substantial modification of its electoral franchise, nor will it assist actively the movement for the closer settlement of the country, and its general influence is seen in the steady process of alteration which is applied to all the legislation sent up by the Assembly, while in 1907 alone two Bills were rejected.

In Western Australia the first Council was nominated, but provision was made for the election of the Council so soon as the white population amounted to sixty thousand, or six years had elapsed since the first summoning of a nominated Council. This elective body received, on its creation in 1894 , full powers of amendment in the form of requests for amendments in money Bills. In other respects the Council has equal legislative power, and in 1907 there resulted a rather violent dispute between the two Houses on the question of the imposition of a land and income tax. The government asked the Governor to grant them a dissolution, and on his declining to consent to this, offered to resign. Sir Frederick Bedford, however, demurred to this proposal also, and instead prorogued Parliament for a time in order that a modus vivendi

the case of the second passing of the Bill absolute majorities are required on the second and third readings in the House. 
should be arranged, with the most satisfactory result that ultimately the measure went through in a somewhat altered shape, though its unpopularity cost the government some support at the election of 1908 .

In all these cases the Upper Chamber is the Conservative Party - that is, so far as any Australian party can be regarded as conservative. But in the case of the Commonwealth, the Senate is ultra-democratic, and parties in it are divided rather on the basis of labour and anti-labour, the two sides being almost or quite equally balanced if there are reckoned as assisting the Labour Party the supporters of the government. As a result its share in legislation has been stoutly democratic, and it has asserted its full right to amend and reject measures proposed to it by the Lower House, including, as has been seen, even the tariff, and to initiate legislation.

Except in special circumstances in Victoria and South Australia, the Council cannot be dissolved, and changes in its political complexion can only come in gradually as the Chamber is renewed every two or three years by the retirement in rotation of some of the councillors. In this respect these Chambers differ from the legislative Council of the Cape of Good Hope, which can be dissolved by the Governor when he dissolves the Assembly, though he is also entitled to dissolve the latter by itself. The Cape Council has constantly maintained its position as an essential power in the State, and has recently appeared as in effect determining the fate of a Ministry. In the beginning of 1908 there terminated a long struggle between Dr. Jameson's government and the Opposition by the resignation of the Premier, on the discovery that the elections for the Council had gone decidedly against him. The dissolution which took place was indeed forced on him by the Council. Parties in it were precisely equally balanced, and the turn over of one member deprived the government of its majority in committee, as opposed to in 
the ordinary business of the House. The result was that in Committee of Supply the government found that no progress could be made with their financial proposals, and though, whenever the House was not in committee, they still had a majority, they could not induce the Opposition to forego the advantage they had in committee except on an undertaking to dissolve after the granting of Supply, the Opposition very properly offering to secure the grant of Supply if a dissolution were agreed upon. This undertaking was eventually given; Supply was granted; and the general election returned a decisive majority for the government formed by $\mathrm{Mr}$. Merriman $(r)$.

One device to secure greater co-operation between the two Chambers is in foree in the Cape, that of permitting Ministers to speak in either House, though they may only vote in that House of which they are members. The same rule is in use in the case of Natal, and the two new Colonies of the Transvaal and Orange River, in which, at present at least, the Upper Chamber is nominated, and to a limited extent in Victoria.

In the case of the Commonwealth there is made provision for the prevention of a deadlock. If the House of Representatives twice at an interval of three months, whether in the same or a second session, passes a Bill and the Senate will not accept or amends it unsuitably, the Governor-General may dissolve both Houses, and if on the House of Representatives again passing the Bill the Senate still reject it, the Governor-General may convene a joint sitting of the Houses at which the voting is as one House, and an absolute majority of the votes is required to carry the Bill $(x)$.

In the case of the legislatures which have nominee Upper Chambers, the rule is now fully established that such

(v) Cf. House of Assembly Debates, 1907, pp. 582, 589, 590, 597 ; Legislative Council Debates, 1907, passim.

(x) Cf. Harrison Moore, Commonwealth of Australia, pp. 124-127. In the case of a constitutional deadlock the procedure is simple. See sect. 128 of Constitution, where the electors decide, provided a majority of States agree. 
Chambers cannot claim anything like equal rights in financial natters with the Lower Chambers. In the Dominion of Canada a money Bill must be recommended by a message from the Governor-General, and originate in the Lower House $(y)$. The same rule is laid down in the Constitution Act of New South Wales (z), and is implied in the rule in the New Zealand Constitution that money Bills must be recommended to the House of Representatives by the Governor. The Queensland Constitution Act $(a)$ follows in this, as in many other details, the New South Wales Act, while the Natal Constitution Act $(b)$ goes a little further, and adds that such Bills may be rejected, but may not be altered by the Council. The same rule is in force in Newfoundland by constitutional practice, the law only requiring the Governor's reconmendation (c). The position has not altogether passed without question, but in 1862, and again in 1872, the law officers of the Crown advised that the claim of the Council in New Zealand to be on an equality with the Lower House as regards money Bills was not well founded (d), and in 1886 a dispute between the two Houses in Queensland was formally referred to the Judicial Committee of the Privy Council for decision $(e)$. The advice of the Privy Council was to the effect that the Queensland Council had not equal powers with the Assembly as regards such Bills, a decision which is obviously correct, and in which the Council has acquiesced.

On the other hand, while the doctrine is fully established that the Lower House is supreme in matters of money, the

(y) 30 Vict. c. 3 , 88. 53,54 .

(z) 17 Vict. c. xli. 8. 1 (schedule to $18 \& 19$ Vict. c. 54 ).

(a) 31 Vict. c. $38,8.2$.

(b) No. 14 of 1893 , ss. $48,49$.

(c) 5 \& 6 Vict. c. 120 , 8. 3.

(d) Constitution and Government of New Zealand, 1896, pp. 194-205.

(e) Parl. Papers [C. 4794], H. L. 214, 1894. 


\section{RESPONSIBLE GOVERNMENT IN THE DOMINIONS.}

power of the Upper House to reject is still fully maintained, and there is no understanding similar to that of 1860 in the United Kingdom, when the House of Commons asserted its right to control absolutely the grant of Supply by framing its Bills in such a way that the Lords could not, consistently with the possibility of carrying on government at all, refuse their concurrence. There is indeed, in this respect, a real and not inconsiderable difference between the Colonies and the United Kingdom, though, of course, in the Colonies with nominee Councils, there is just as little chance as in the United Kingdom of throwing out an appropriation Bill dealing with general supply. On the other hand, Bills dealing with particular items are liable to rejection just as much as any ordinary piece of legislation. Perhaps more exactly it might be said that in the Colonies the government must prevent interference by putting into one Bill all its financial proposals, while the fact that the government could do so is sufficient in the United Kingdom $(f)$.

As in financial matters, the nominee Chambers cannot hope to maintain full equality in general legislative power with the Lower Houses. This has from the first been the case in Canada, where the Dominion Senate has altogether failed to obtain the consideration which would seem to be natural to its position as representing the interests of the provinces as against the federation. Various causes have contributed to this result. In the first place, though the selection of Senators was originally intended to be exercised by the Governor-General, acting as an imperial officer, the actual nomination soon, and probably inevitably, fell into the hands of the government of the day. Secondly, the nominations were made for life, and these two facts rendered

(f) Cf. Anson, Law of the Constitution, i. 268 ; Queen Victoria's Letters, iii. 401 seq.; Morley, Life of Gladstone, ii. 24-41. The Commonwealth Constitution, s. 55, forbids tacking ; 6 C. L. R. 41. 
the Senate a sort of resting place for politicians who were tired of, or unwilling to face, the electoral struggles. Chosen by Dominion Ministers, they were naturally chosen for their share in Dominion politics, and the provinces had no voice whaterer in their selection. In consequence it is said that not only has the Senate shown no desire to preserve State interests against the central government, but that it has even been somewhat hostile to the provinces, and this view seems confirmed by the fact that the provinces have on more than one occasion expressed dissatisfaction with the existing mode of selecting the Senate. Prior to 1896 , the Senate was comparatively seldom in opposition to the government, except during the Ministry of Mr. Mackenzie, when the Senate and the Ministry were totally opposed to each other in connection with the case of the proposed dismissal of the LieutenantGovernor of Quebec, Mr. Letellier, who was condemned by the Senate but supported by the Commons. After the defeat of the Liberals at the elections in 1878, and the commencement of the long Conservative control of Parliament, the Upper House, most of whom were nominees of the Prime Minister, were generally in accord with the Lower House. This changed completely in 1896, when the Conservatives fell, and in 1897 and in 1898 the Senate actually threw out Bills, passed by substantial majorities in the Lower House, to extend to Montreal the inter-colonial railway, and to build a railway into Klondike. The former measure was rejected on the ground that it would unduly favour the Grand Trunk at the expense of the Pacific Railway, the latter because the land grant system in this case was deemed undesirable and too extravagant. A good deal of irritation was evidently felt by the Commons, and projects of reform were mooted, especially during the election campaign of 1903, but the matter passed over, and in later years the Senate has come more and more into the position of registering the decrees of 
the Lower House. In both 1906 and 1908 debates $(g)$ took place as to the feasibility of altering the House so as to make it elective, and the general current of opinion was shown in favour of some change.

It should be noted that in theory the position of the Senate is a strong one, as it cannot be swamped, only an addition of six members being possible, and such an addition requiring the approval of the Crown. It has been laid down that the power is one meant for use only in a grave emergency when the two Houses are completely at variance, and when the addition of the number of members permissible would be sufficient to terminate a deadlock.

The history of the New South Wales legislature $(h)$ is in some respects of special interest. As originally constituted, the legislative Council consisted of members nominated for five years from 1856 , but at the end of that period it was arranged that the Council should be composed of not less than twenty-one members, nominated for life by the Governor with the advice of his executive Council. On the 4th February of that year the Secretary of State addressed a despateh to the Governor, advising him that it would be desirable to avoid the error of making the legislative Council a mere party assembly, and suggesting that it might be desirable that the existing members should be continued in their seats. Sir John Young replied in two despatches, in which he reported the formation of a very representative Council, not by any means a mere party body, the number of twenty-three including twelve persons who had sat in the former Council. He added that parties in the colony were agreed to restrict the number of councillors to twenty-seven as a rule. But he also reported that the last days of the Parliament had been

(g) Canada House of Commons Debates, 1906, pp. 2276 seq.; 1908.

(h) Parl. Yapers, H. C. 198, 1893-94, pp. 69-99. 
spent in a dispute between the Council and the Assembly. The government were anxious to settle the land question, but the Council unexpectedly declined to compromise, and rejected the government's proposals ; while the Assembly, by large majorities, rejected the proposals of the Council. His Ministers accordingly asked him to create some twenty-one new members to swamp the Opposition in the Upper House, and as they were supreme in the Assembly and had the confidence of the country the Governor consented to do so, on the clear understanding that the gentlemen to be nominated were to hold their positions for a single night only, and would have no claim for permanent nominations on the reconstruction of the Council. The device failed, for the Opposition, getting to know of the wholesale creation of councillors, stayed away in a body, and the President hastily resigned, selling all his property in the colony, so that no House could be formed, and the government's measures could not be carried into law.

In his reply (i) to the despatch reporting this curious incident, the Secretary of State administered a rather severe rebuke to the Governor for his action in the matter, and decidedly discountenanced the practice of swamping the Council. This rebuke was evidently borne in mind, for in $1865(k)$ the Governor forwarded to the Secretary of State a correspondence showing that the Colonial Secretary had resigned his post because of the Governor's refusal to add two members to the Council on the advice of his Ministers. The Governor justified his conduct by considerations based not only on the state of the government which was not in possession of the confidence of the country, and which indeed was shortly afterwards defeated on a vote of confidence by

(i) Ibid. p. 74 .

(k) Ibid. p. 75 . 
forty-two to fourteen votes, but also on general grounds. He argued that, if the understanding was once violated which restricted the numbers of the Council to about twenty-seven, there would be no possibility of avoiding depriving it of all independent power and strength. His action led to the resignation of Mr. Forster, the Colonial Secretary, but the other Ministers did not feel entitled to resign on that account, especially as there was impending the vote of censure which ultimately defeated them. The Secretary of State extended a full approval to the action of the Governor.

His successor, Lord Belmore, consented in $1868(l)$ to increase by three the numbers of the Council, bringing it up to thirty, but only on the ground that there was considerable difficulty in getting a quorum to transact business. The Secretary of State approved his action, though regretting that any addition had been found necessary as liable to impair the validity of the general principle of the limitation of the numbers of the Council. In fact, in the very next year, the Governor received representations from Mr. Robertson $(m)$ on behalf of the Ministry, in which it was categorically laid down that the rule of restricting the Council was merely a convenient arrangement and not any part of the Constitution, and that the right undoubtedly existed in Ministers to ask for and receive any addition which they thought necessary for the conduct of business. If this were refused, Ministers would be entitled to resign, and leave the Governor the duty of forming a new government. In reply to these views, the Secretary of State, while admitting that there must exist the right of overcoming resistance to the popular wishes by the Council by nominating further members, asserted that this power was an extraordiuary reserve power which should only be exercised in cases of 
grave dispute, while the regular use of the power to override the wishes of the Council would deprive the Council of all authority.

So far the view held by the Colonial Office had clearly been that the Council should be treated like the House of Lords, and the debates at the time when the Constitution was framed show that the Council was indeed meant to play. some such part, as Mr. Wentworth $(n)$, in adrocating a nominee against an elective Council, laid stress on the fact that the nominee body could ultimately be brought into harmony with the elected House, while an elective Council would be a perpetual check on progress. In $1872(0)$ opinions had changed, and Sir Henry Parkes boldly attacked the question of reconstituting the Upper House, which had hopelessly differed from his government over the question of collecting revenue on the Victorian frontier of the colony. But recognising that the carrying of any proposal to make the Council elective would, in the face of the opposition of that body, be extremely difficult, he asked the Governor to accept the principle that a Minister was entitled to receive any additions to the Council which he might need to force its opinions into conformity with his own. The Governor reported the matter to the Secretary of State, who pointed out in reply that the system of nomination might work better if the principle were adopted of only making appointments for a term of years, thus securing the gradual alteration of the Council contemporaneously with the advance of public opinion in the colony, and he reminded the government that difficulties were as frequent with elective Upper Houses. $\mathrm{He}$ pointed out the solid grounds of convenience, on which the existing rule of the limitation of the Council rested, and while professing a desire to avoid interference with the

(n) In Dec. 1854. Ibid. p. 80.

(o) Ibid. p. 87. 
internal affairs of the colony, said that he would be glad to learn that the Ministry had not insisted on making all the appointments desired.

It was assumed by Lord Glasgow in 1892, in his dispute with the New Zealand Government, to which allusion will be made later, and also by Mr. Todd $(p)$ and other authorities $(q)$, that this correspondence maintained the principle of the limitation of the numbers of the Council. But as a matter of fact, though the immediate proposals failed, and in 1876 a motion to make the Council elective was decisively negatived in the Assembly, the Secretary of State had in effect admitted that the matter was entirely one for the decision of the local government, while pointing out very weighty reasons why the government should accept the principle of limitation, which indeed owed its origin in part to the well-known views of the Imperial Grovernment, and in part to a voluntary understanding between the political parties of the years 1861 to 1865. In 1889 Sir Henry Parkes secured considerable additions from Lord Carrington, and protests from the opposition were not accepted as valid, and at the present day the number of councillors has grown to fifty $-\operatorname{six}\left(r^{*}\right)$ The result has of course been the loss by the Council of a good deal of its authority and position : it now revises measures and exercises a limited power of rejection $(s)$, based on the fact that no colonial Ministry regards the mere failure to pass a measure as fatal to its existence; but it is now part of the Constitution that any government is entitled to swamp the Upper House, if it

(p) Parl. Govt. p. 658.

(q) Jenkyns, British Rule and Jurisdietion beyond the Seas, p. 67. Cf. the refusal of an increase to Mr. Reid's Ministry in 1894, Times, Sept. 14th, 1894; Anson, Law of the Constitution, ii. 278, n. 1; Parl. Papers, H. C. 70, 1889, p. 43.

( $r$ ) A large recent increase of the numbers has taken place, much criticised by the Opposition in Parliament. Parliamentary Debates, 1908, Sess. 2, pp. $79 \mathrm{seq}$.

(s) Cf. New South Wales Parliamentary Debates, Ixxii. 7483. 
thinks fit, and any Governor who declined to accept the nominations of his government for the Council would be required to find another Ministry ready to take office and carry on government.

In 1872 there arose, as noted above, a dispute between the two Houses of the New Zealand Parliament over the question of amending money Bills. The Upper House claimed that the Parliamentary Privileges Act of 1865 put them on an equality in this respect with the Lower House, and, accordingly, the matter was referred to the decision of the law officers in England, who decided that the Upper House had no right whatever to amend, either by its position or by reason of the Act of 1865 . The Upper House, however, remained in enjoyment of its full privileges of amending other Bills, and in 1892 the two Houses came to serious differences. In 1891 the Governor was asked to add eleven members to the Upper House by Sir H. Atkinson's Ministry. He considered the number excessive, especially as the Ministry was weak in the country, but after negotiation consented to create six new councillors and did so. The Ministry shortly afterwards resigned, and the Governor was informed by the Secretary of State that in acting on ministerial advice he had acted in accordance with constitutional principles, whatever judgment might be passed on the action of Ministers in tendering the advice. The incoming government then asked for a number of appointments to make good the position of the government in the House; they did not desire to swamp the House but only to have a fair representation. The new Governor, Lord Glasgow, was unwilling to accept their proposals in their entirety, but he was ready to appoint nine of the twelve councillors for whose appointment Mr. Ballance asked. The government, on his declining to aceept their advice to its full extent, remained in office on the ground that, if the Governor's action were proper and in execution of his 
imperial functions, they would not be justified in resigning, and, instead, appealed to the Secretary of State, who in a despatch of the 26th September, $1892(t)$, decided in favour of their claim to have the desired number of appointments made, on the ground that no imperial interest was involved, and that the Governor in such a case should follow ministerial advice. The decision, coupled with the fact that under an Act passed in the preceding year appointments are for seven years only, and not for life, has secured the harmonious working of the two Houses since that date, the Upper House accepting the Old Age Pensions Act of 1898, and the Industrial Conciliation and Arbitration Act of 1900, and so forth. It was proposed in the session of 1907 that the Upper House should be made elective, and the majority of the House of Representatives appeared to be in favour of the change, but the Prime Minister expressed himself as against it, and the matter was not further pressed. Indeed, in view of the present satisfactory state of the relations of the Houses alteration would seem unnecessary and undesirable $(u)$.

In Queensland the Legislative Council was, under the local Constitution Act of 1867, protected by the requirement that any alteration in its constitution could only be passed by a two-thirds majority in either House of the Parliament. This provision was attacked as early as 1870 as being undemocratic, a similar provision in the Constitution of New South Wales having disappeared as early as 1857. But the Council were not then prepared to allow the curtailment of their powers, and the Bill was not permitted to pass. In the next year an amended Bill was brought forward and became law. It no longer sought, as in the Bill of 1870 , to repeal the requirements of two-thirds majorities in the case of laws affecting the election of the Assembly and the appointment

(t) See Parl. Papers, H. C. 198, 1893-94, p. 39.

(u) See Parliamentary Debates, 1907, pp, 276-303. 
of the Council, but merely related to the question of the election of the Assembly and was passed. The relations between two Houses, of which the Upper had to assent by so considerable a majority to its alteration, could hardly be satisfactory; and, as a matter of fact, in 1885 the differences between the Houses over the power of amending money Bills grew so strong that a reference to the Privy Council was agreed to and carried out. The decision $(x)$ of the Privy Council was adverse to the Council. It was held that the position of the Council was analogous to that of the House of Lords, and that the control of supply rested with the Lower House, subject merely to a right of rejection where such right could be exercised by the Lords. This decision ended the dispute as to powers in money matters, but in other respects the Council retained its full power of amending Bills right up to the year 1907. In that year $(y)$ the Council was generally opposed in feeling to the legislation promoted by the Premier, Mr. Kidston, who owed his parliamentary majority to a working alliance with the Labour Party in the Assembly. They accordingly decided to reject two measures on which great stress was laid by the government; the one a proposal to extend the principle of wages boards to all agricultural occupations-a measure disliked by the farming interest--the other to curtail the use of the postal vote, which was believed to be mainly advantageous to the Opposition. The Premier, in view of this opposition, then asked the Governor for a dissolution, but Lord Chelmsford declined to give him one and the Premier resigned. His place was taken by the Leader of the Opposition, who, however, was in a decided minority in the Assembly, and who, therefore, being unable to obtain supply or to carry any legislation, applied to the Governor for a dissolution. The Assembly

(x) Parl. Papers [C. 4794], H. L. 214, 1894.

(y) Queensland Parliamentary Debates, 1907, Nos. 35, 36 ; 1908, Nos. 2, 3. 
protested vigorously against any such dissolution being given, on the ground that they were ready to go on with business, i.e., with Mr. Kidston's programme ; but the Governor decided that he should grant the dissolution, in view of the importance of the country deciding on the issues in question, practically the position in the State to be occupied in future by the Council. On a general election ensuing, the country left the comparative position of parties almost unaltered, thus restoring Mr. Kidston to power, when his Ministry passed a vote in the Assembly expressing their regret at the action of the Governor in granting a dissolution, and in thus delaying the carrying out of necessary schemes for the benefit of the country, particularly as regards railway construction. But the result of the dissolution and the general election was unusually satisfactory and very creditable to the government: no attempt was made to swamp the Upper House, a process which, of course, would merely mean fresh swamping at every change of government, but a Bill was brought forward and passed to make void the proviso in the Constitution Act of 1867, under which the consent of a twothirds majority in either House was needed for any change in the composition of the Council. This Bill was claimed to be ultra vires (z), but the government easily showed that there was no foundation for such a claim, and the Bill passed both Houses, was assented to, and became law. Then the government introduced a measure to provide for a referendum to the people in the case of future deadlocks between the Houses. If a Bill is passed by the Assembly and rejected by the Council, and again passed by the Assembly in a subsequent session and rejected by the Council, it may be referred to a vote of the electors, and if passed by a simple majority of those

(z) On the ground that the proviso of a two-thirds majority was thus rendered nugatory, which was true but irrelevant. Contrast the wording of the proviso at the end of sect. 128 of the Commonwealth Constitution and Harrison Moore, Commonwealth of Australia, p. 322. 
exercising the franchise on that occasion, then it shall be presented to the Governor for his assent, and treated as if it were an ordinary law passed by the two Houses. The legislative Council were not altogether satisfied with the terms of the Act, but they recognized that the general election had decided the case against them, and it finally passed by a majority of two, was reserved, and received the Royal Assent by Order in Council. The Council, however, obtained amendments specifying that the Bill should not be represented to the Council for acceptance until three months had passed from the date of the first rejection of the Bill, and that no Bill was to be deemed to be rejected unless it was sent up to the Council not less than one month before the close of the session, in the case of the first passing of the Bill, and not less than a week in the case of the second passing. This procedure is, it will be observed, very much more democratic than that of the South Australian Act, No. 779 of 1901, for the prevention of deadlocks, which requires a general election between the two passings of the disputed Bill, and only allows a very moderate degree of pressure to be exerted on the Upper House (a), but this difference is due mainly to the fact that the Upper House in South Australia is elective, and cannot be ignored to the same extent as a mere nominee chamber $(b)$.

The position of the Upper House in Natal is one of somewhat unusual strength, derived from the mode. in which the House is composed. The Natal people were at first anxious to have but one chamber, but the prevailing feeling in England then was in favour of the bicameral system, and in the result there was constituted a nominee body, composed as follows since the annexation of Zululand and the ceded

(a) This will be modified slightly by the passing of the new Bill now under consideration, p. 113 .

(b) See Queensland Act, No. 16 of 1908.

i. 
territories of the Transvaal. Thirteen members are summoned by the Governor in Council-five from within the counties of Durban, Victoria, Alexandra and Alfred, three from within the counties of Pietermaritzburg and Umvoti, three from within the counties of Weenen and Klip River, one from the province of Zululand, and one from the New Territory, but not more than two members can be chosen from any one county. The members only hold office for ten years, and the five senior members retire by rotation every five years, the first retirements having been decided by ballot. As a result the Council is always receiving the effects of the entrance of members with fresh political ideas, and, like the Council of New Zealand since 1891, is not impervious to the political forces arising among the people. Further, the strict limitation of the place of choice, coupled with the requirement of ten years' residence in Natal, thirty years of age, and ownership of property worth 500l., tend to secure that the members of the Council shall be persons calculated to count in the counsels of the colony. Certainly the Council is expressly forbidden by the Constitution to amend money Bills, but it freely asserts its right of rejecting any money or other measures sent up by the Assembly of which it does not approve. Even in 1905, after the resignation of Sir George Sutton's Ministry, the Council, though there was pressing need for the provision of funds to meet the deficit in the colonial finances, successfully exerted its right to reject the particular measure of native taxation put before them by the government. It may also be said that, in certain cases, the influence of the Council has been thrown on the side of the natives, and has led to the modification of legislation framed without due regard for their interests, a duty which is particularly incumbent in the Upper House as less likely to be affected by popular prejudices.

In the case of the Transvaal and the Orange River Colony, 
the first Councils have been made nominee instead of elective, partly because of the difficulty-which weighed with the Natal government in 1893 - of finding any convenient basis of discrimination between the two Houses as regards franchise, and partly to admit of the service of the first Parliament of those who, after faithful service in the earlier nominee legislature, could hardly be expected to expose themselves to the rough-and-tumble of an electoral conflict $(c)$. But the nominee body was only contemplated to last for five years, and it was open to the legislature at any time after four years had expired from the first meeting of the Council to make the legislative Council elective. Provision was also made for deadlocks as follows :- If the Assembly twice passes in successive sessions a law and the Council rejects it, or makes amendments in which the Assembly will not agree, then the Governor may, if he thinks fit, either convene a joint session of the two Houses or dissolve the Assembly, or, if the Council is elective, both Houses. If, on re-assembling, the Assembly again passes the law and the Council rejects it, the Governor may hold a joint session. In either case of a joint session the law is to be voted upon by the members of the two Houses sitting as one body, and if it receives an absolute majority of the members of the two Houses taken together, it is to be deemed to have been passed, and is to be presented for the Governor's assent $(d)$.

So far the nominated Councils have not shown any great independence, and in both Colonies the government has secured a majority on the Councils as well as in the Assembly.

(c) Cf. Parl. Papers [Cd. 3250], p. 39. See Letters Patent, Dec. 6th, 1906, 8. 7 ; Letters Patent, June 5th, 1907, s. 7. In both cases the Cuuncil cannot amend money Bills.

(d) These provisions are borrowed, but modified, from the Commonwealth precedent. No general election is essential before a joint sitting, and in this point the provisions are more democratic than elsewhere, except in Queensland, under Act No. 16 of 1908. 
On the other hand, the Council in the Transvaal has asserted its right to be given adequate time to consider all legislation on the occasion of the passing of the Bill regarding Asiatics. In all probability the Upper Houses will ultimately become elective, but the provisions to prevent deadlocks will probably simplify the procedure in the case of any constitutional disputes between the Houses of Parliament.

- Of the other Colonies, the only one remaining which has a nominated Council is Newfoundland. In that case the councillors are nominated not for life but during pleasure, but their number is limited to fifteen, so that there is no possibility of the Council being swamped by the government of the day $(e)$. The relations of the Council and Assembly are, however, usually in harmony, and the Council is essentially the weaker House. It has no claim to amend money Bills, but sometimes acts independently in ordinary legislation. For example, in 1906-1908 it steadily refused to accept a Bill relating to the use of steamships in the Labrador fisheries, presumably because, as passed by the Lower House, it did not safeguard treaty rights. The nominee Councils of Quebec, of twenty-four members, and Nova Scotia, of twenty-one members, occupy a similar position to the Lower Houses in these Provinces. In both cases the nomination is by the Lieutenant-Governor (who acts on the advice of his Council) for life.

(e) The Crown, through the Secretary of State (Letters Patent of March 28th, 1876), cuuld increase the Council indefinitely, but the Governor cannot appoint any members so as to cause the resident members in Newfoundland to exceed fifteen. Although in all cases, except those of Natal, the Transvaal, and the Orange River Colony, the Governor in theory appoints, the actual action is always done on the advice of the executive Council, the Govcrnor's discretion being confined to refusal to appoint. It would obviously be impossible for the Crown to appoint members of its own motion. 


\section{CHAPTER VIII.}

\section{THE FEDERATIONS.}

The British Empire is unique in counting among the number of its self-governing Dominions two federations of great extent and vast potential resources. Federal government is, indeed, no rare thing in the Empire. To a very limited extent there is a federal administration for the Windward Islands, and a real federal union exists in the case of the Leeward Islands, but in neither case is the phenomenon of any real importance compared with the case of Australia and Canada. It is probable that to this number may be added the States of South Africa, but though the signs are in favour of federation, it must be remembered that in 1877 the Imperial Parliament actually passed a Federation Act for the South African Colonies, which remained a dead letter, and that there are many advantages in the alternative proposal that there should be a unification of the South African administrations, which are too numerous for the population and resources of the country.

\section{A. Canana.}

Canada is the oldest and the most perfect representative of federation. Circumstances in Canada, indeed, pointed to federation as the natural end to be achieved. The provinces had all along been bitterly at variance with one another: there was no immediate bond of union between them, their history was different, and their traditions ran in opposite currents. On the other hand, their position of helplessness 


\section{RESPONSIBLE GOVERNMENT IN THE DOMINIONS.}

in face of the growing menace of the United States rendered federation almost inevitable, and it is significant of the importance of this fact that the government of the States was believed to be decidedly hostile to federation, which substituted for scattered and feeble provinces a united and powerful Canada. Moreover, the existence of the French element in Quebec suggested at once the adoption of a plan which would leave each colony to its own devices as regards internal affairs, but would unite them for the common action which is essential for the maintenance of imperial unity. It is, perhaps, the absence of this external pressure which has caused the difficulty of framing a satisfactory Constitution for Australia (a). The particularist tendencies of the States have only imperfectly been counterbalanced by the natural and proper conception of an Australian nationality. It was, indeed, not until the last moment that the advice of the Imperial Government induced the government of Western Australia to accept federation, and New Zealand definitely and finally declined to have any part in the federation. In the case of New Zealand the decision was no doubt wise and in harmony with the best interests of the Dominion: its long distance from Australia, the difference in its history and circumstances and in the character of its population, would certainly justify the standing aloof from the main land of Australia, whose interests in many respects are not at all in agreement with those of the Dominion. The main disadvantage of the position is undoubtedly with regard to the Western Pacific, where there must be a divided control between the two colonies, even after the Imperial Government surrenders its management of the protectorates now included in the Western Pacific High Commission.

The essential feature of a federation is that for external

(a) Cf. Harrison Moore, Commonwealth of Australia, Chap. II. 
purposes it should be regarded as a unity. This is the case with the Canadian federation. As regards the Imperial Government it stands in the position of a single colony, with a Governor-General appointed by the Crown, and responsible to the Crown for the conduct of the government of Canada. The federal government is the sole channel of correspondence between the Crown and the provincial governments; even the Agents-Generals of the provinces are not allowed to enter into direct correspondence with the Imperial Government. If the Imperial Government desires to make representations to a provincial government the representations go through the Canadian Government, and are couched in such shape as seems good to that government, which never adopts the attitude that a provincial matter is one for the sole consideration of the province in the sense that the Dominion Government is a mere conduit pipe of correspondence between the Imperial and provincial governments. Further, in the all-important matter of foreign relations and treaty obligations the Canadian Government is supreme : section 132 of the British North America Act, 1867, gives the government and the Parliament full power to take whatever steps are necessary for the carrying out of any treaty obligation incumbent on Canada or on any province. Accordingly, all consuls are accredited to and approved solely by the Canadian Government; the provincial governments are not officially consulted as to their appointment or the termination of their recognition. So all treaties in which Canada takes part are concluded for the Dominion as a whole, and the established practice is that, if the matter of the treaty be a question which falls under the class of topics reserved for the exclusive legislative authority of the provinces, then the Dominion will only adhere to the treaty if the provinces consent, but if it adhere at all will adhere on behalf of the whole of Canada. Indeed, technically speaking, it would seem legitimate for the Dominion 
to adhere whether the provinces agree or not $(b)$, but the established rule seems far better in practice, as the other rule would, in effect, be to usurp, under the guise of adhering to treaties, part of the exclusive legislative power of the provinces. This might be, in some definite instance, necessary, and the existence of the reserve power seems a safeguard, as the Dominion in the long run must decide such a question for Canada; but it is a power of the kind which should be exercised with the utmost caution and rarity.

The legislative power in Canada is divided between the provincial legislatures and the Federal Parliament, on the principle that the federal government should have all the powers which are not specifically assigned to the provinces. The latter powers are enumerated in section 92 of the British North America Act, and include-(1) the amendment of the constitution of the province, save as regards the office of Lieutenant-Governor; (2) direct taxation within the province, in order to raise a revenue for provincial purposes; (3) the borrowing of money on the credit of the province; (4) the establishment and tenure of provincial offices; (5) the management of the public lands of the province, a privilege not, however, granted to Manitoba, Alberta and Saskatchewan; (i) the establishment and management of prisons; (7) asylums and charities, other than marine hospitals; (8) municipal institutions ; (9) shop, saloon, tavern, auctioneer, and other licences for the purpose of raising a revenue for provincial, local, or municipal purposes; (10) local works and undertakings other than lines of steam or other ships, railways, canals, telegraphs, and other works and undertakings con-

(b) Section 132 would, then, seem to give the necessary legislative power to make good the adherence. But I am not aware of any case in which Canada has adhered against the wishes of a provincial government. The British Columbia representatives in the Federal Parliament concurred in the adherence, in $1905-6$, to the treaty with $J_{\text {apan, which was practically a federal }}$ matter. 
necting the province with any others of the provinces or extending beyond the limits of the provinces, lines of steamships to other countries, and works declared by the Dominion Parliament to be for the public advantage of two or more provinces; (11) the incorporation of companies with provincial objects; (12) the solemnisation of marriages ; (13) property and civil rights; (14) the administration of justice and civil procedure ; (15) the imposition of punishment for offences against any law of the province; and (16) all other matters of a merely local or private nature in the provinces. In matters of education the provincial legislatures have, under section 93 , exclusive legislative power, but the power is not to be exercised so as to affect prejudicially any rights as regards denominational schools existing in the provinces at the Union $(c)$. Moreover, where in any province a system of separate or dissentient schools existed by law at the Union, or is thereafter established by the provincial legislature, an appeal lies to the Governor-General in Council from any act of the provincial authority affecting any right or privilege of the Protestant or Roman Catholic minority of the people of the province as regards education. In case the provincial Parliament does not pass the necessary legislation to carry out the decisions of the Governor-General, or do not legislate in accordance with the provisions of the section, the Parliament of the Dominion in that case alone has the power to pass remedial legislation to the extent required to carry out the end of the section and the decisions of the Governor-General. In regard to agriculture and immigration, the provinces may, under section 95, make laws as to agriculture and immigration into the provinces, but such legislation can always be overridden by a Dominion statute.

Other matters are left to the Dominion Parliament, and,

(c) Further, all privileges granted in Upper Canada to Roman Catholic schools were to be extended in Quebec to dissentient schools. 
in particular, as falling within their competence may be mentioned-(1) the public debt and property; (2) the regulation of trade and commerce; (3) the raising of money by any system of taxation; (4) the borrowing of money; (5) postal services; (6) the census; (7) militia, military and naval service and defence; (8) civil offices in Canada; (9) beacons, buoys, lighthouses; (10) navigation; (11) quarantine; (12) sea coast and inland fisheries; (13) ferries between a province and a British or foreign country, or between two provinces; (14) currency; (15) banking and paper money; (16) savings banks; (17) weights and measures; (18) bills of exchange; (19) interest; (20) legal tender; (21) bankruptey and insolvency; (22) patents ; (23) copyright; (24) Indians and lands reserved for them; (25) naturalisation and aliens; (26) marriage and divorce; (27) the criminal law, including procedure, but not the constitution of courts of criminal justice; (28) the establishment and maintenance of penitentiaries; and (29) all subjects not specifically assigned to the provincial legislatures.

Naturally the result of these two enumerations has been conflict, from which the following principles have been evolved by the action of the Privy Council $(d)$. The powers allowed to the two legislatures are as far as possible to be read together, and to be given full force to by modification so as to reconcile the whole. Subjects, which in one aspect and for one purpose may fall within the powers of the Dominion, may in another aspect fall within the powers of the provinces $(e)$. But the provinces remain as much as before federation no mere holders of a delegation of legislative power, but retain their independence and autonomy within the sphere left to them, and not created for them by

(d) See especially Citizens' Insurance Co. v. Parsons, L. R. 7 App. Cas. 96.

(e) Hodge v. Reg., L. R. 9 App. Cas. 117. 
the British North America Act $(f)$. The Crown is as much a part of the legislature as before, and in fact laws are made still in all the provinces save Nova Scotia, New Brunswick, and Prince Edward Island in the name of the King. The use of the formula, Lieutenant-Governor, in these three cases has no significance as showing that the Crown is not part of the legislature; it is merely an old survival, of no more constitutional significance than its persistence in the case of Newfoundland, South Australia, and Tasmania, where it is not doubtful that the Crown remains part of the legislature. This point was clearly brought out in the judgment in the Privy Council in the case of Hodge v. Reg., in which it was decided that the legislature of Ontario could delegate to a board of commissioners powers to enact regulations as to taverns, as it was in no sense a delegate of the Canadian Parliament, and could exercise the authority still remaining in its hands, in as full and ample a manner as the Imperial Parliament can exercise the authority it wields. Similarly in the case of the Att.-Gen. for the Dominion of Canada. v. Att.-Gen. for the Province of Ontario $(g)$, it was laid down, overruling a famous decision of the Supreme Court of Canada, in Lenoir v. Ritchie.(h), that the provincial legislatures had power to provide for the appointment of local K.C.'s, although the Governor-General alone could appoint counsel for the Dominion, such provincial counsel being entitled to precedence in the provincial Courts, as against the claim of the Federal Government to exercise the right. So also the provinces have made provision for the exercise of the prero-

(f) Liquidators of the Maritime Bank of Canada v. Receiver-General of New Brunswick, L. R. [1892] A. C. 441. Cf., however, Lefroy, Legislative Poucer in Canada, pp. 15 seq.

(g) L. R. [1898] A. C. 247.

(h) 3 Can. S. C. R. 575 ; ef. Lefroy, pp. $87 \mathrm{seq}$. 
gative of mercy in provincial cases by the LieutenantGovernors, although the Governor-General has the prerogative for all Canada by the Letters Patent and Instructions issued by the Crown. The Lieutenant-Governor is no mere official; he is, so far as he goes, a representative of the Crown, and similarly the Crown, as represented by the provincial government, is a preferential creditor over creditors whose securities are of the same character, as was decided in the case of the liquidation of the Maritime Bank of Canada.

A neat example of the dovetailing of the powers of the two legislatures has been seen in the case of legislation as to liquor. It has been decided (i) that the Canada Temperance Act, 1878, which in effect, whenever put into force, prohibits the sale of intoxicants except in wholesale quantities, or for certain definite purposes, and makes sales in violation of the law criminal, and punishable by fine, and for the third or subsequent offence by imprisonment also, is within the powers of the Dominion, the objects of the law being general, to promote temperance by a uniform Dominion law, and this characteristic of generality is not altered by provision for the special application of the Act to particular places. On the other hand, the province may legislate to impose special rules regarding taverns, \&c., these being regulations of a police or municipal character of a local nature, and not interfering with the general regulation of trade and commerce reserved to the Dominion Parliament. Or, again, while the Dominion alone can create a corporation with power to carry on business all over Canada, and while the fact that that corporation only did business in one province could not affect its status as a corporation or render its original incorporation ultra vires the Dominion, yet the mode of conducting its operations in

(i) Russell v. Reg., L. R. 7 App. Cas. 829; see 32 Can. Law Journ. 430 ; cf. Att.-Gen. for Manitoba v. Manitoba Licence Holders' Association, L. R. [1902] A. C. 73 . 
the particular province must be strictly in accordance with the law of that province, and taxation can be levied on such companies $(k)$.

Other decisions affect the question of the position of the Crown in the provinces as compared with the Crown in the Dominion. Each province has the full beneficial interest in all lands within its boundaries which at the time of the Union were vested in the Crown, subject only to the transfer of certain property to the Dominion by section 108 of the Act, and to the right of Canada to acquire lands or public property required for the defence of the Dominion. Accordingly, when lands in Ontario, which had been reserved in 1763 for the use of Indian tribes, were surrendered to the Dominion in 1873, subject to a qualified privilege of hunting and fishing, it was decided that the lands were the beneficial property, not of the Dominion, but of the province, subject only to the qualified rights of the Indian tribes over the lands $(l)$. Considerable difficulty has arisen of late, because the British Columbia Government hold that if any native lands conveyed by them, under the thirteenth section of the terms $(m)$ on which the province joined the Union, to the Dominion Government, are parted with by that government, the right to the lands at once reverts to the province, so that the Dominion cannot sell the lands and apply the proceeds for the benefit of the Indians.

Further, escheats in Canada are the property of the Crown in the province, and not in the Dominion (n). This was much disputed in Canada, where the view held was rather that the Crown was only fully present in the Dominion Government,

(k) Colonial Building and Investment Association v. Att.-Gen. of Queber, L. R. 9 App. Cas. 15?; Lefroy, Legislative I'ower in Canada, pp. 617 seq.

(l) St. Catherine's Milling and Lumber Co. v. Reg., L. R. 14 App. Cas. 46 ; cf. [1903] A. C. 73 ; Lefroy, p. 594, n.

(m) Order in Council, May 16th, 1871.

(n) Att.-Gen. of Ontario v, Mercer, L, R. 8 App. Cas. 767. 
but the Privy Council decided that the word "royalties" in the section 109, reserving rights in lands in the provinces to the provincial governments, conferred on the Crown in the provinces the right to escheats. Similarly when the result of an ordinary conveyance of land by a prorincial government to the Dominion was discussed $(o)$, it was held that nothing save express words would be adequate to transfer the right of the Crown in the province to the precious metals under the lands in question, another emphatic assertion, as against the views both of the Dominion Government and of the Canadian Supreme Court, of the fact that a Canadian province is still essentially connected with the Crown, and the LieutenantGovernor is really a representative of the Crown.

Further, the Courts $(p)$ have decided that the right of the Parliament of Canada to legislate for the peace, order and good government of any territory not included in any province, gives the Parliament the widest discretion as to the character of the legislation which it may enact, and obviously this principle extends to all legislation of the Canadian Parliament, within its own sphere of action, and no Court can question its acts on the ground that in the opinion of the Court they are not really calculated to secure the ends aimed at. This was one of the points taken by the appellants in the case of the rebel; Riel.

The sole control of the criminal law given to the Dominion excludes the right of the provinces to punish any act which is criminal at the common law. So it was held $(q)$ that an enactment of Ontario making it punishable to tamper with a witness in the case of prosecutions under the Liquor Licence Act was ultra vires, as the act was already an offence at the

(o) Att.-Gen. of British Colunbia v. Att.-Gen. of Canada, L. R. 14 App. Cas. 295 ; Lefroy, op. cit. pp. 609-611.

(p) Riel v. Reg., L. R. 10 App. Cas. 675.

(q) Reg. v. Lawrence, 43 Upper Can. Q. B. 164. 
common law. Nor can the provincial Courts effect any alteration in the laws of evidence in criminal matters $(r)$. It appears now to be established $(s)$ that the provincial legislatures can inflict both fine and imprisonment for any offence, and can make the imprisonment carry with it a sentence of hard labour.

The control over marine and fisheries conferred on the Dominion does not extend to depriving the provinces of their ownership of the beds of rivers in the provinces $(t)$, but merely allows the Dominion Parliament to regulate generally the rules of fishing, and so forth. It has also been held that the provinces cannot confer on any provincial company the right to obstruct a river by setting booms across it $(u)$.

The wide term "trade and commerce" had given rise to much doubt. It has, however, been decided $(x)$ that its application must be to wide legislative powers, such as political arrangements as to trade, or arrangements as to inter-provincial trade, or, perhaps, general regulations for trade throughout the Dominion, but that it certainly does not extend to the regulatiou of particular trades in particular provinces.

On the other hand, the general control of property and civil rights ascribed to the provinces must be read subject to the powers given to the Dominion to deal with patents, copyright, lands reserved for Indians, bankruptcy and insolvency, and the general right of the Dominion to affect private rights, in so far as is necessary to give full effect to its power of legislation on the topics, which admittedly

(r) Reg. v. Roddy, 1 Cart. 709 : Lefroy, op. cit. pp. 379, 467.

(s) Paige v. Griffith, 2 Cart. 324 ; Lefroy, op. cit. p. 38.

(t) Reg. v. Robertson, 2 Cart. 65.

(u) Queddy Boom.Co. v. Davidson, 10 Can. S. C. R. 222.

(x) Citizens' Insurance Co. v. Parsons, L. R. 7 App. Cas, 112. 
fall within its legislative competence. But with these exceptions the power is plenary, and has been used to legislate so as to alter a testator's will $(y)$, and even to upset the ordinary rule of international law that the debts belonging to persons not domiciled in the province are situated at the place of domicile (z). So, also, under an Act of 1905, the Quebec Parliament provided for the levy of death duties on property which, under the ordinary principles of private international law, would not be deemed to be situate in the province; and there are similar laws in Ontario and Prince Edward Island.

Other complicated problems arise out of the rule as to taxation. The provinces can only raise direct taxation, and accordingly it has been held ultra vires for a province to raise money by what was in effect a Stamp Act on policies of assurance $(a)$; and, again, a tax on exhibits in a Court case is an indirect tax, as the person who files the exhibit is not necessarily the person on whom the burden will ultimately fall $(b)$. On the other hand, a tax on banks in proportion to paid-up capital and on insurance companies on a sum specified in the Act was held to be legal, on the ground that it was the intention of the Act that the corporations themselves should actually bear the $\operatorname{tax}(c)$. And the taxation may be imposed on a particular locality for a local purpose, and need not be imposed on the whole province for a provincial purpose $(d)$. On the other hand, there is no power in any provincial legislature to levy a tax on the salaries of federal

(y) Re Goodhue, 1 Cart. 560.

(z) Nickle v. Douglas, 35 Upper Can. Q. B. 126: 37 ibid. 51. This is, however, ultra vires the province. Cf. Woodruff v. Att.-Gen. for Ontario, L. R. [1908] A. C. 508 ; above, p. 82.

(a) Att.-Gtn. for Quebcc v. Queen Insurance Co., L. R. 3 App. Cas. 1090.

(b) Att.-Gen. of Quebec v. Retd, L. R. 10 App. Cas. 141.

(c) Bank of Toronto v. Lambe, L. R. 12 App. Cas, 575.

(d) Dow v. Black, L. R. 6 P. C. 272. 
officers, as this would be an interference with the undoubted right of the Federal Government to fix the salaries of federal officers $(e)$.

The province can levy indirect taxation only as regards certain licences, but the issue of licences is not confined to the raising of a revenue, as suggested by the wording of subsection 9 of section 92 of the Act, as it has been held that the power to provide for municipal institutions includes the power to issue licences as a mode of exercising the necessary control over matters of municipal concern $(f)$.

The Dominion cannot in any way alter the provisions of the constitutions of the provinces, which is a matter left entirely for the provincial Parliaments. But there is some difference in the exact relations of the several prorinces to the central power. The Dominion primarily consists of the provinces of Ontario, Quebec, Nova Scotia, and New Brunswick, which all joined in 1867, to which must be added British Columbia and Prince Edward Island, which joined in 1871 and 1873 respectively, under special conditions $(g)$, which, however, place them generally in the position of original provinces. Manitoba was created by Dominion legislation, confirmed by an Imperial Act of 1871 , and the same Act (h) gave the Dominion power to create further provinces on the understanding that the legislature once fixed could not be altered by the Dominion, though, with the consent of the new province, the Dominion could alter its boundaries. The Dominion has, however, in creating, in 1905, Alberta and Saskatchewan, made little change from the general plan of provincial government, except as regards public lands and minerals, the control over which it retains.

(e) Leprohon v. City of Ottawa, 1 Cart. 592.

(f) Reg. v. Frauley, 7 Ontario App. Rep. 246.

(g) Orders in Council of May 16th, 187l, and June 26th, 1873.

(h) $34 \& 35$ Vict. c. 28.

K. 
An interesting example of the conflict of the powers granted to both legislatures is to be found in the case of the permission to limit emigration to the province given by section 95 of the British North America Act. In 1878 the Supreme Court of British Colnmbia held that an Act passed by the provincial legislature in the preceding Session was invalid, because it required every Chinese person over twelve years of age to take out a licence every three months, paying ten dollars on each occasion in lieu of other taxation, as it lay with the Dominion Parliament to legislate on trade and commerce, the rights of aliens, and the obligation of treaties $(i)$. In 1884 the provincial legislature passed another Act to cause Chinese to pay a licence fee, and prohibiting the entrance of Asiatics, but this legislation was disallowed (k). In 1905 and in 1907 fresh Acts were passed imposing a dictation test on the entrance of immigrants, but on both occasions the Acts were not permitted to come into force by the Dominion Government. In 1908, on the other hand, the Act was permitted to become law, but was finally held by the Supreme Court of the province to have no effect. As against Japanese immigrants it was inoperative, because its terms conflicted with the terms of the Dominion Act, confirming and giving statutory force to the Canadian adherence to the Japanese Treaty of 1894. In the case of Asiatics, it was contrary to the provisions of the Dominion immigration law as consolidated in 1906, under which there was a statutory duty on the officials of the government to permit the immigration into Canada of any person who passed the tests prescribed by the Dominion legislation. It would, therefore, appear

(i) Lefroy, op. cit. p. 423 : British Columbia Sess. Papers, 1879.

(k) Cf. also Union Colliery Co. of British Columbia v. Bryden, L. R. [1899] A. C. 580, where a British Columbia Aet forbidding the employment of Chinese underground was held in effect to be intended to prohibit their residence in the province; but the disqualification of Japanese voting is intra vires; see Cunningham v. Tomey Homma, L. R. [1903] A. C. 151. 
that any immigration legislation which British Columbia could frame would be ultra vires, or rather without effect, as repugnant to Dominion legislation binding on the province.

The case illustrates the fact that the Dominion has a right to disallow the Acts of the provinces when it deems them contrary to the interests of the Dominion at large. The propriety of the exercise of the power can hardly be questioned when the point at issue is legislation by the provincial Parliament on matters which are within the control of the Dominion. The question of the general exercise of this power of disallowance which was conferred upon the Dominion Governor-General by the British North America Act of 186i, superseding the right of the Crown to disallow provincial Acts, was carefully considered by the Dominion Minister of Justice in 1868, when the Acts of the provinces first came before the notice of the Federal Government. It was then laid down that interference with provincial legislation should be restricted within the narrowest possible limits, and should be confined to cases in which the law was considered to be ultra vires the provincial legislature or inconsistent with Dominion legislation, or where the proposed enactment was contrary to the policy which, in the opinion of the Governor-General in Council, should prevail throughout the Dominion in regard to the point at issue.

Disallowance on the first of the grounds is not at all rare, and, indeed, if the provinces are to hare full self-government, it would be extremely inconvenient that there should be many doubtful statutes on the law books of the provinces. But disallowance is confined as a rule to fairly clear eases of legislation ultra vires : in doubtful cases the rule is to point out to the province the part of the law which requires alteration, and, if the province undertakes amendment, to leare the Act in operation, while if the matter is quite doubtful, the law may be left to the Courts to pronounce upon. Instances

ᄂ 2 
of such disallowance occurred more frequently in the early years after confederation, before the real limits of the powers of the Dominion and the provinces were fixed, and they have been more rare of late years. For example, in $18^{\times} 3$ the Governor-General disallowed an Act of New Brunswick which purported to interfere with the navigation of the St. John river, and in 1887 a Manitoba Act affecting the office of the Iieutenant-Governor. In 1869, after reference to the law officers of the Crown in England, the Governor-General disallowed an Act of the Ontario Parliament, which purported to define the privileges of the Legislative Assembly as being ultra vires. On the other hand, though regarding as of doubtful validity, the Dominion Government did not press for the disallowance of another Act on the subject passed in 1876 , and the Supreme Court eventually upheld the power of the provincial legislatures to pass such Acts. In all only seventy Acts of the 12,843 passed by the provinces up to 1990 have been disallowed, which shows how carefully the power to disallow has been exercised $(l)$.

Very grave difficulties, have arisen in the question of the disallowance of provincial Acts which are admittedly within the powers of the provincial legislatures. The only justification for such action is, as the Privy Council of Canada recognised in 1868, and again in disallowing certain Manitoba Acts in 1885, the belief that the policy embodied in the Acts is directly counter to the interests of the Dominion as a whole. In 1871 the legislature of New Brunswick passed certain Acts relative to education, which the Governor-General was advised by the Minister of Justice should be left to its operation as it was within the competence of the province under

(l) See Canada Sess. Papers, 1882, No. 141; 1885, No. 29; Report of Minister of Justice, April 1st, 1886; Sess. Papers, 1889, No. 47; 1893, No. 33 ; and Lefroy, op. cit. pp. 140-201. For the question of the provinces versus the federation, cf. Egerton, Canada, pp. 314-325; Todd, Resp. Gort., pp. 521 seq. 
the North America Act. But as it interfered with the privileges in fact enjoyed by Roman Catholics before the Act was passed, the Dominion House of Commons desired that the law officers of the Crown should be consulted as to whether there was not ground for remedial legislation. The law officers, however, advised that there was no case for remedial legislation, and the Privy Council decided that the matter was not oue in which they could intervene. On learning this result, the Canadian House of Commons asked that the Governor-General should be advised to disallow certain amending Acts passed by the proviucial government at the last session of the legislature, but the Governor-General only agreed on the adrice of Ministers to refer home for instructions, when he was directed to leave the Acts to their operation, as they were within the constitutional powers of the province $(m)$. In $18 \pi 5$, the legality of the law having. in the meantime beeu affirmed by the Supreme Court and the Privy Council, the Commons petitioned the Crown to use its influence with the province to secure the establishment of separate Catholic schools, but the Crown, while expressing the hope that the province would take any necessary measures to relieve the situation, replied that the interference with the province asked for would be very undesirable.

The same question arose agaiu in $187 \pi$, when P'rince Edward Island legislated as to public schools. The new Act only continued the old law as to non-secturian education, but it ignored certain illegal practices under which the Catholics had introduced books of their own choosing iuto the schools. The Catholics petitioned the Guvernor-General to disallow the law, but the Minister of Justice advised that disallowance would be improper, as the matter was within the competence of the legislature, though certain provisions appeared severe and arbitriry. In 1881, on the other hand,

(m) Canada Sess. Papers, 187i, No. 89. 
an Ontario Act was disallowed because it violated private rights without making compensation, and the Ontario Parliament rehemently protested against the disallowance on the ground that every Act within the competence of the legislature should be allowed. In 1885, several Acts of Manitoba were disallowed because they conflicted with the railway policy of the Dominion, under which, as expressed in the agreement with the Pacific Railway Company, no line was to be authorized for twenty years within fifteen miles of latitude 49, or south of the Pacific Railway unless it ran south-west $(n)$. But in 1888 the Federal Government in effect yielded by buying the company's rights.

Despite the protest of the provincial governments, it must be assumed that the Dominion Government has established its claim to disallow any Act it pleases, and that the duty of disallowance rests with the Governor-General in Council. A different opinion was held by the Secretaries of State in the period 1869 to 1877 . It was then decided by Lord Granville in 1869 that it was the duty of the GovernorGeneral as a rule to act on the advice of his Ministers in deciding as to the allowance of provincial Acts, but he expressly reserved the cases in which the Governor-General might think, despite the advice of Ministers, that an Act ought not to be allowed to come into force. In 1872, however, the Lord President of the Council, in refusing to intervene in the matter of a New Brunswick Education Bill, did so on the ground that the decision as to such Bills was vested in the Governor-General acting under the advice of his constitutional advisers, and that the Queen in Council had no jurisdiction in the matter. The last part of the reason was sufficient to dispose of the appeal for interference, but on the first part Mr. Blake based an argument that the power to disallow could only be exercised validly on the advice of

(ii) Muuro, Constitution of Canada, pp. 260 seq. 
Ministers, so that a Governor-General who wished to disallow on imperial grounds must find Ministers to do so. Lord Kimberley had in 1873 by anticipation contradicted this doctrine by asserting that the power of disallowance was one for the individual discretion of the Governor-General, and Lord Carnarvon, in reply to Mr. Blake's memoraudum, asserted the principles, that the British North America Act did not contemplate the iuterference of the Dominion Parliament or the government in cases of Acts which were within the powers of the provincial legislatures, and that the power of disallowance rested with the Governor-General. Mr. Blake demurred to this conclusion, and the Secretary of State replied by urging that the section 90 of the British North America Act, which gave the power of disallowance of provincial Acts, vested it in the Governor-General alone. $\mathrm{He}$ suggested that the Governor-General must act with the advice of his Ministers, but that he need not necessarily accept it. This suggestion and the argument from the wording of the clause were both attacked by Mr. Blake, and the controversy then closed. But the result was favourable to the contention of Mr. Blake, as the power has since always been used on the advice of Ministers, and never in contradiction to their advice. In fact, it would seem in strict law to be necessary that any disallowance should be male in Council, because the rules as to the disallowance of provincial Acts are to be the same under the British North America Act as those for the disallowance of Dominion Acts, with the substitution of the Governor-General for the Queen, and the power to disallow Dominion Acts can only be exercised in Council. If, therefore, a Governor-General tried to disallow a provincial Act without the concurrence of Ministers the validity of the disallowance might be questioned in the Courts (o).

(0) See Canada Sess. Papers, 18i6, No. 116. Jenkyns' view that the 


\section{RESPONSIBLE GOVERNMENT IN THE DOMINIONS.}

Of course, the result is anomalous, as it leaves it open to a provincial legislature to pass an Act which tells against imperial interests and which, if passed by a colonial government, would not be allowed to remain in operation. Presumably the danger is less, because the provinces are not empowered to legislate on the important imperial matters such as treaty rights, aliens, naturalisation, \&c. But the Imperial Government retains, of course, full power and right to suggest alterations of provincial laws to the Dominion, and to ask the Dominion, if necessary, to disallow Acts, while in the long run an Imperial Act could cancel any provincial Act or could restore to the Governor-General the power of disallowing in his capacity as an imperial officer. For example, the Imperial Government in the year 1899 moved the Dominion Government to see to the disallowance of Acts passed by the British Columbia Government unfavourable to the Japanese, and the Dominion Government acted on their representations, while the disallowance of British Columbia Acts in $190 j$ and 1907 were based on imperial as well as Dominion wishes.

As regards executive control over the provincial governments, the Dominion Government stands very much in the position of the Imperial Government towards that of the Dominion, though the latter naturally interferes much more with provincial rights on federal grounds than the Imperial Government with Dominion rights on Imperial grounds. The pusition of the Lieutenant-Governors is in some respects anomalous, as they are appointed by the Governor-General on the advice of his Ministers, and can be dismissed by him alone. It was, accordingly, long argued that they were merely Dominion officials, and unable to exercise any part of the royal prerogatives, while the legislatures of the provinces

Governor-General can disallow provincial Acts (British Rule and Jurisdiction, p. 119) is certainly incorrect. Cf. Lefroy, op. cit. p. 202. 
were considered incompetent to affect by their legislation the prerogative. This doctrine has been finally exploded by a series of decisions of the Privy Council, the last of which decided that the Lieutenant-Governors can be authorized by statute to appoint King's Counsel and to assign them precedence in the province, while other decisions mentioned above established the right of the Crown in the province to such prerogative rights as escheats $(p)$. The LieutenantGovernors are appointed by Commissions under the. Great Seal of Canada, and in just the same way as the Governors of Colonies from the Secretary of State, they receive instructions as to the conduct of their duties from the Secretary of State for Canada, who represents the Dominion Government. The control of the Dominion is made sccure by the right of dismissal for cause assigned, but the assigning of a reason, which must be communicated to the LieutenantGovernor and to the Parliament of Canada, does not impose any restriction on the right of dismissal: it merely ensures that the ground must be made public, and facilitates a discussion on the action of the government as regards the dismissal.

The position of a Lieutenant-Governor is therefore by no neans altogether easy. He is bound both by his iustructions and by constitutional practice to carry on the government of the province by means of a provincial Ministry, which may or may not be in harmony with the Dominion Government; in many cases it is simply not in such harmony. If he does not manage to find Ministers, le could not reasonably continue in office; but clearly if the Dominion insisted on trying to make him a political machine for Dominion ends, he would not be able to find men prepared and able to carry on the government of the province. Accordingly, the Dominion Government, as a general rule, observes an

(p) Cf. Lefroy, op. cit., pp. 90 seq. 


\section{RESPONSIBLE GOVERNMENT IN THE DOMINIONS.}

attitude of strict political neutrality in such matters $(q)$, and only intervenes in questions where the Dominion interests are believed to be deeply involved. This rule has not been without exception, and the classical example of interference is that of the dismissal of $\mathrm{Mr}$. Luc Letellier de St. Just, the Lieutenant-Governor of Quebec, by the Macdonald Ministry in 1879, an instance in which the Dominion must be admitted to have overstepped the bounds of its functions. In March, 1878, Mr. Letellier dismissed the De Boucherville Ministry because he found that they were bent on pursuing a policy of railway construction to which he was not prepared to assent, and which he believed to be due to a corrupt pressure brought to bear on them by irregular combinations of members for political considerations to promote a lavish expenditure on subsidies to railways. The Leader of the Opposition, Mr. Joly, accepted the task of forming a Ministry, and, finding himself defeated in the Assembly, asked for and received a dissolution, which returned him to power and enabled him to proceed with business. The ex-government then appealed to the Opposition in the Dominion Parliament, and the matter was debated in the Dominion Senate and House of Commons, the motion of censure of Mr. Letellier's action being carried in the Conservative Senate but rejected by the Liberals in the Commons. But the Dominion Parliament was dissolved that year owing to efflux of time, and the Mackenzie Administration, on being beaten at the polls, gave place to that of Sir John Macdonald; and while no official action was taken by the government, their supporters raised the matter

(q) This does not, of course, prevent the intervention of individual Ministers in non-fecieral politics, as, for example, of Mr. Fielding in Nova Scotiu, of which he was formerly Premier. The passing of provincial statesmen into federal politics is interesting and churacteristic. Australia promises differently. 
in the Commons, with the result that a majority of eightyfive voted that Mr. Letellier's dismissal of his Ministers was unwise, and subversive of the position of Ministers under responsible government. The Prime Minister then represented to the Governor-General that, in view of the resolution of the Senate in 1878 and of the Commons in 1879, the usefulness of $\mathrm{Mr}$. Letellier as a Lieutenant-Governor was gone, and they asked for his dismissal. The GovernorGeneral was unwilling to accept this advice, and considered that the dismissal would form a dangerous precedent; and, on the suggestion of Lord Lorne, the matter was referred home to the Secretary of State, while the Quebec government sent home their Premier to argue in favour of the LieutenantGovernor's action and against any interference with provincial rights. It was suggested by Mr. Joly that a reference to the Privy Council would be a satisfactory means of disposing of the question, but the Secretary of State negatived the proposal on the ground that there was no basis on which the Privy Council could exercise jurisdiction, the Dominion Government not having assented to that means of procedure, and there being no way of enforcing any decision arrived at by the Privy Council. Finally, the Secretary of State gave his decision, which he based solely on the constitutional position of the Governor-General and not on the merits of the case. He laid down the view that the matter was essentially a local one in which the usual rule of acting on ministerial responsibility naturally applied, and he negatived the argument against this, which had been derived from the wording of sect. 59 of the British North America Act, which assigns the appointment of the LieutenantGovernor to the Governor-General in Council, but the dismissal to the Governor-General simply. But, at the same time, while giving the ruling that the matter was one in which the Governor-General should not overrule Ministers, he 
expressly laid stress on the fact that the appointment of Lieutenant-Governors was intended to be for five years unless they were removed for grave reason, and that disagreement in political opinions from those in power at Ottawa could not be deemed adequate reason for so summary a step as dismissal. The Dominion Government, however, though showing appreciation of the arguments of the Secretary of State, persisted in advising the dismissal of Mr. Letellier, and the GovernorGeneral, in accordance with the advice tendered to him, accepted the Order in Council dismissing the LieutenantGovernor, in whose place Mr. Robitaille was appointed.

A good deal of quite indefensible argument $(r)$ was used by Mr. Letellier's supporters during the crisis, and he himself asserted, in a memorandum in his defence, that he was irresponsible for acts performed within the legitimate sphere of the duties prescribed to him by the British North America Act. To admit this would be impossible, and subversive of the parallel position assigned to the Lieutenant-Governors as regards the Dominion Government with that of the GovernorGeneral as regards the Imperial Government. But, on the other hand, the Lieutenant-Governor had even a greater claim on the consideration of the Dominion Government than the Governor-General on the Imperial Government, for the pust of the former represented an essential compromise in the desire to reconcile the local autonomy of the province with the Dominion control of the federation. This fact is recognized in the provision for a five years' tenure of office and dismissal only on reason assigned and made known to Parliament, whereas the imperial officer has no fixed

(r) Contrast the case of the dismissal of Mr. T. McInnes in 1900 from the government of British Columbia, because he insisted in dismissing Ministe ${ }^{x_{8}}$ who were opposed to the Liberals in federal politics, in the hope of securing a Ministry in political sympathy with his party. Canada Sess. Papers, 1900, No. 174 . 
tenure of office, and his removal can be made at pleasure without any cause whatever being given. The argument against the Lieutenant-Governor's action as inconsistent with the place assigned the Ministry by the rules of responsible government could not be considered at all satisfactory. It would, indeed, be a complete negation of responsible government as understood in the Colonies to lay down the rule that a Governor must always accept ministerial advice (s). It is sufficient that he should be bound to do so or to find other advisers. This the Lientenant-Governor was both ready and able to do, and his new Ministry was quite adequate to all purposes of government. Under these circumstances the removal could only be regarded as a mere act of party spirit, and the action was none the less discreditable to the Dominion Goverument that it was not due to any overt act on their part, but was forced on them by the action of their supporters. The responsibility rested on them to secure that no use should be made of mere party feeling in a matter affecting vitally the independence of provincial government within its own limits, and Professor Egerton, in his recent History, notes as significant that no mention is made of the episode of the dismissal of Mr. Letellier in the official record of the doings of Sir John Macdonald, from which it may fairly be deduced that that statesman was not especially proud of his part in the action taken $(t)$.

There has been no repetition of such interference with the acts of any provincial Lieutenant-Governor, though the Ottawa government retains of course the right to instruct their Lieutenant-Gevernors in all matters in which they regard Dominion interests as involved, and the LieutenantGovernor is bound to obey these instructions, even if such obedience brings him into conflict with opinion in the pro-

(s) See Chap. IV., and p. 29, note (c).

(c) Pas.l. Papers [C. 2445]; Egerton, Canada, p. 315. 
vince. For instance, in 1907 the Parliament of British Columbia passed a Bill to put restrictions on the entry of immigrants which was intended to keep out Japanese and British Indians, and the Lieutenant-Governor was instructed not to assent to it. On the other hand, in 1908 he was instructed to assent to an Act in similar terms, because the Dominion Government thought it better to take the matter out of the hands of the local government, and leave the question of the validity of the law to the judgment of the Courts.

While the Dominion has thus a certain measure of control over the provincial governments, and in the appointment of all the Judges of the Supreme Courts, \&c. (u), the provinces are supposed to bave their interests represented in the Dominion Parliament by, the Senate, which is composed at present of eighty-seven members, of whom twenty-four represent Ontario, twenty-four Quebec, ten Nova Scotia, ten New Brunswick, three British Columbia, and four each the four remaining provinces. These numbers are fixed by the British North America Act, save only that an Imperial Act of 1886 has provided that the Dominion Parliament can make provision for the representation in the Senate of new provinces. Theoretically, therefore, the provinces should have a very adequate protection to their wishes in the Senate, subject to the fact that the numbers of the Senate are based not on an equal representation of all provinces $(x)$, but an equal representation of Ontario and Quebec, and an equal but smaller representation of Nova Scotia and New Brunswick. This latter fact may in part explain the undoubted fact that the Senate has not played any very definite part in Canadian history. Its composition and uses received a most searching

(u) 30 \& 31 Vict. c. 3 , s. 96.

(x) Harrison Moore, Commonuealth of Australia, p. 118. The Australian Senate has an equal number (six) for each original State. 
criticism in debates in 1908 in the Senate itself and in the House of Commons, in which were discnssed in detail the possibilities of making it more effective as a revising and critical body. It was suggested that it would be desirable to make it elective, but this plan did not seem on the whole to be favoured by the majority of the House of Commons.

The small part played by the Senate is no doubt due in the long run to the fact that senators are nominated, and thus have no control of the purse, and feel that they cannot claim to speak as the representatives of Canada. In one respect the Senate's position is very strong; it cannot be swamped by the government of the day to give themselves a party majority; the total number of senators who can be added, even in an emergency, is six, and the power to summon this number is, by the Act of $186 \%$, vested in the Crown on the recommendation of the Governor-General. An application for the exercise of the power has only once been made in 1873, when the government, in order to facilitate the control of public business in the House, asked for the addition of six members. The request was refused by the Secretary of State on the ground that the power giren by the Act was clearly intended to be quite an exceptional power, only to be used in the event of such a deadlock between the Houses as could only be removed by the intervention of the Crown, and such as could be satisfactorily removed by the propused addition of so small a number of senators.

There remains, however, to the provinces the resource of an appeal to the Imperial Government. The arrangements of 1867 , and the subsequent proceedings by which new provinces were admitted, are regarded as a quasi-treaty, which, like treaties generally, cannot be modified at the pleasure of any one party to the compact, and the Imperial Goverument has on various occasions asserted its readiness to 
intervene in questions of this kind, at least, to the extent of suggestion and discussion. In 1868 the Assembly of Nova Scotia appealed to the Secretary of State on the ground that the Act of Union was not really advantageous to the province, that it had been passed without the people of the province being fully consulted, and asked that it might be repealed. The Imperial Government declined to reverse the policy of union, but made such representations to the Dominion Government as secured the passing of measures to allay the discontent of the province $(y)$. In 1873 the government of British Columbia made very strong protests against the delays taking place in connection with the completion of the intercolonial railway, and after much discussion the Secretary of State arbitrated between the two parties and settled terms of compromise. Further delay, however, occurred, and for years there was trouble between the two governments, which successive Governors-General endeavoured to allay by their personal efforts, and eventually, by mutual forbearance, the whole problem was solved and the railway construction ended (z). Curiously enough, with regard to the same province, a new cause of quarrel arose in 1907 on the question of the increase of the provincial subsidies of the Dominion. British Columbia and all the other provinces were granted increases after a conference between all the parties interested, but the government of British Columbia claimed, on account of her limited resources and the vast amount of developmental work needed to render the province as flourishing as it should be, that a special allowance should be made, and though the Dominion and the other provincial governments were ready to give an allowance over and above the ordinary subsidy, they differed by a hundred thousand dollars a year as to the amount. When, therefore, the

(y) Canada Sess. Papers, 1869, No. $9 ; 1870$, No. 41.

(z) Ibid. 1875, No. 19 ; 1876, No. 41 ; Egerton, Canada, pp. 291 seq. 
Dominion Government came to England and asked the Imperial Government for an amendment of the British North America Act the British Columbia Government sent in opposition a delegation to persuade the Imperial Government to insist on the increase of the British Columbia subsidy. The Imperial Government naturally declined to set themselves up as a Court of Appeal in the matter, and felt that they could not insist on subjecting all the other provinces and also British Columbia to loss of the increased subsidies which were being offered by holding up matters for a further consideration of the provincial claim, but in announcing this decision to the Premier of British Columbia it was clearly pointed out that the Imperial Government recognised that the matter was one in which the relations between the Dominion and provincial governments were rather of a treaty character than those of mere law $(a)$.

The provinces are also protected against the encroachment of Dominion rights by the fact that the Supreme Court has no jurisdiction in cases of disputes between the Dominion or the provinces, or between the provinces inter se. But this position has been altered by consent by the provincial legislatures, and the provinces of Ontario, British Columbia and Nova Scotia have agreed that the Exchequer Court of Canada will have power to adjudicate in eases of dispute between them and the Dominion or between the provinces concerned $(b)$.

(a) British Columbia Parl. Papers, 1907 ; Parl. Pupers, H. L. 85, 1907.

(b) Munro, Constitution of Canada, p. 219. Contrast the rase of the Commonwealth, Harrison Moore, Commonucalth of Australia, pp. 262 seq. See also the dispute as to the Ontario boundary (Egerton, Canada, pp. 318, $319)$, settled, by the Act of 1889 , by the Imperial Government at the request of Canada. Parl. Papers, H. C. 346, 1889.

K. 


\section{B. Australia.}

In nearly every respect there are striking contrasts between Australia and Canadian federalism, illustrative of the essential fact that the Australian Federation is, compared with the Canadian, somewhat artificial and less due to the influence of a powerful and formidable power ulose at hand. Further, the fact that the Australian Federation took place at a later date was not without effect on the attitude adopted to the Imperial Government. The Canadian Government is most jealous-and very properly so--of its powers of selfgovernment, but it is equally willing to recognise that the Constitution itself and the division of federal powers rest on the act of the Imperial Parliament, and therefore in the important matter of the relations of provinces and Dominion they have not been unwilling to recognise the right of the Imperial Government to intervene. On the other hand, the Australian Commonwealth is constituted on the basis that as far as possible everything in it shall be complete and capable of modification from within, so that there will be no possibility of imperial interference. The two tendencies have helped to produce somewhat contradictory results: the first has tended to put the states in a quasi-independent position; the latter has made the Federal High Court, which is composed of federalist lawyers and federal nominees, supreme over the interpretation of the Constitution, and while of course beyond suspicion of any lack of judicial action, they have tended to develop it, as might be expected, in a very federal as opposed to a state way.

The powers of legislation bestowed on the Commonwealth are, unlike those of the Dominion, limited and definitely defined. In the case of Canada, all legislative power vests in the Dominion unless it is given specifically to the province; in the Commonwealth, the residuary power belongs to the 
state and not to the Commonwealth. The Canadian Constitution does not contemplate that, save on one or two points such as immigration, there will be concurrent powers of legislation, and, though as we have seen in certain matters there exist in fact the power of legislating to much the same effect in both the province and the Dominion, that is not due to any direct conflict of legislative power, but only to the fact that in one aspect a matter may fall under the Dominion, in another under the provincial powers of legislation. But the Commonwealth Constitution leaves to the state practically all their existing legislative powers, but duplicates them in many instances, giving the Commonwealth legislatiou the overriding power. The exclusive legislative powers $(c)$ are mainly confined to that of determining and legislating for the seat of government-which, after a decision in 1904, is still in the melting pot, that decision having been reversed in 1908-that of regulating the affairs of the transferred departments $(d)$ of the State Governments, viz., posts, telegraphs and telephones, naval and military defence, lighthouses, light-ships, beacons and buoys, quarantine, customs and excise. The Commonwealth has concurrent powers of legislation $(e)$ in a vast variety of matters, including (i.) trade and commerce ; (ii.) taxation ; (iii.) bounties; (iv.) borrowing money on the credit of the Commonwealth; (viii.) astronomical and meteorological investigations; (xi.) census and statistics; (xii.) currency, coinage, and legal tender; (xiii.) banking other than state banking; (xiv.) insurance other than state insurance; (xv.) weights and measures; (xvi.) bills of exchange and promissory notes; (xvii.) bankruptoy

(c) Sect. 52 of Constitution (Sohedule to $63 \& 64$ Viot. c. 12).

(d) Sects. 69 and 51 (v.)-(vii.), (ix.).

(e) Sect. 51. The exact result of the co-existence of two lawa is doubtful. If the Commonwealth law is repesled, I think the state law has effect. Contra, Harrison Moore, Commonwealth of Australia, p. 174. 
and insolvency ; (xviii.) copyrights, patents and trade marks and designs; (xix.) naturalisation and aliens; (xx.) foreign corporations and trading or financial corporations formed within the Commonwealth; (xxi.) marriage; (xxii.) divorce; (xxiii.) invalid and old age pensions; (xxiv.) the service of criminal and civil process of the states throughout the Commonwealth ; (xxv.) the recognition throughout the Commonwealth of the judgments and laws of the states; (xxvi.) the people of any race, other than aboriginal, for whom special provision must be made; (xxvii.) immigration and emigration; (xxviii.) the influx of criminals, \&c. In other cases the powers given, though not expressed to be exclusive, are in fact so; e.g., the power to legislate for (x.) fisheries in Australian waters beyond territorial limits; perhaps (xxix.) external affairs; and certainly ( $8 \times x$.) the relations of the Commonwealth with the islands of the Pacific; while other powers relative to (xxxiii.) the acquisition of railways in the states; (xxxiv.) railway construction in the states; and (xxxvii.) the passing of laws on the request of the states involve the assent of the state concerned. On the other hand, the power to legislate regarding ( $x \times x v$.) conciliation and arbitration in matters of dispute extending beyond the limits of any one state is a direct power to legislate concurrently with, but paramount to, the state concerned.

It is obvious that the duplication of legislative powers will inevitably lead to confusion, unless a wide definition is given to the rule that a Commonwealth law overrides a state law to the extent of the repugnancy. Fortunately, as far as the undoubted powers of the Commonwealth go, there seems no desire on the part of the states to interfere with the Commonwealth. If they desired to do so, it might be easy to raise very difficult questions as to how far the provisions of the Commonwealth Immigration Act of 1901 really rendered invalid all the provisions of the existing immigration laws of 
the states. The passing of a quarantine law in 1907-1908 led to violent disputes in the Parliament, where the law was declared by many members of the Opposition to be obviously ultra vires the Commonwealth. A Criminal Appeals Bill brought in the same session into the Upper House in order to confer on the High Court a full power of hearing appeals from all criminal Courts was dropped in the same session as unconstitutional. Much more serious, however, than these Bills in the eyes of some constitutional critics is the determination of the Common wealth to control the labour question, one which is not clearly entrusted to it by the Constitution. It was proposed to do this by means of imposing an excise, which would not be levied in cases where a commission declared that the goods were manufactured under satisfactory conditions as to hours, pay, \&c., while other provisions were intended to protect the consumer against the undue raising of prices. The "new protection" would, if held to be not ultra vires the Commonwealth, in effect have put a stop to the operations of the state laws as to conciliation, though there would have been no formal overriding of such laws $(f)$, and would have illustrated the tendency of a federation to absorb all the available powers of government. But the attempt failed, and the Federal Government now propose to amend the Constitution accordingly $(g)$.

In this effort the Commonwealth Parliament has received considerable assistance from the doctrine of implied powers which has been developed by the Federal High Court. This doctrine has its root in the judgment of the great Chief Justice of the United States, Marshall, in $\boldsymbol{Y}^{\cdot}$ Culloch $\mathbf{v}$.

(f) In fact, it was held ultra eires in The King v. Barger, 6 C. L. R. 41, where the Excise Act No. 16 of 1906 was pronounced (a) not to be a real Act for taxation (cf. 1 C. L. R. 49i); (b) to violate the rule against tacking; and (c) to discriminate between states, against sect. 98 of the Con-titution.

(g) Parliamentary Debates, 1908, Nos. 1, 2, \&c. 
Maryland (4 Wheat. 316), and much may be said for its value in interpreting so faulty an instrument as the Constitution of the United States, which can hardly be altered without a movement of popular feeling such as nothing save great crises can bring forth. But the application of the same doctrine seems strange in a Constitution which can be altered easily by the Imperial Parliament, and if cumbrously, yet as the actual practice has shown, still simply enough by the Commonwealth Parliament and electorate itself. This was notably the case in the great income tax cases $(h)$. The view was adopted by the Commonwealth Court that, though the power of the state to tax remained, it must not be used in order to hamper the Commonwealth's operations; and because the state might by excessive taxation impose unfair burdens on Commonwealth officers, it held that the imposition of an income $\operatorname{tax}$ on the income of Commonwealth officers was ultra vires the state legislature; and so with a receipt duty $(i)$ and a stamp duty on lands $(k)$. This doctrine, natural enough in the United States, was decisively rejected by the Privy Council, and the unreasonableness of the exemption was so obvious that the Commonwealth Parliament cut the knot in 1907 by passing an Act for the taxation of the salaries of Commonwealth officers, an unsatisfactory and confused ending to a difficult position, since on the theory of the Commonwealth Court the new legislation was equally unconstitutional.

The question of the division of functions between the Crown as represented by the Governor-General and as represented by the State Governors has been considered by the High Court in the cases of The King v. Sutton $(l)$ and The Att.-Gen. of Neu South Wales v. The Collector of Customs for

(h) Cf. my article, Journ. Soc. Comp. Leg. 1908 : Lefroy, op. cit. pp. 665 seq.

(i) D'Emden v. Pedder, 1 C. L. R. 91.

(k) D' Emden v. Pedder, 3 C. L. R. 807.

(l) 5 C. L. R. 789. 
New South Wales $(m)$. The question which arose there was whether a State Government was exempt from customs duties on goods imported for the purposes of the state. The actual cases were somewhat complicated by the fact that the goods imported consisted of wire netting, which was to have been disposed of at reduced rates to farmers and others; but the cases were decided on principle, and apply to any goods imported by the State Governments.

It was argued for the state authorities that the Crown was only bound by express words or necessary implication by a statute, but it was held that this rule applied only to those representatives of the Crown who have executive authority in the place where the statute applies and as to matters to which that executive authority extends. The Constitution bound the Crown as represented by the various states, and took no account of the states and State Governors in relation to Commonwealth legislation on matters within the exclusive control of the Commonwealth Government, and therefore in the construction of Commonwealth statutes dealing with such matters, the rule applied to the Sovereign as head of the Commonwealth Government, but not to the Sovereign as head of the State Governments. It was pointed out that otherwise all the laws of the Commonwealth could be rendered nugatory, and it was also held that the levying of customs duties was not an imposition of a tax upon property within the meaning of sect. 114 of the Constitution, which forbids the levying of such taxation. The decision appears to be completely conclusive.

On the other hand, the High Court has decided in favour of the states, both as regards the attempt of the Commonwealth to extend its legislation as to conciliation to state servants $(n)$, to legalise the use of a trade union label as a

(m) Ibid. 818.

(n) Federated Amulyamuted Government Railway and Tramuay Service daso. 
quasi-trade mark $(o)$, and to control wages and conditions of labour by excise legislation. The states, however, have lost their case in which they attempted to question the validity of the Additional Appropriation and Surplus Revenue Acts of the Commonwealth, which merely appropriated the full quarter of customs revenue by. ear-marking it for old age pensions and defence.

The Commonwealth, however, remains without direct control over the legislation of the states. The states are indeed forbidden to legislate on various topics $(p)$. They cannot keep up military or naval forces without the consent of the Commonwealth, or tax Commonwealth property (thereverse rule also applies), and they cannot make anything but gold or silver legal tender, or coin money, nor must they discriminate against the citizens of other parts of the Commonwealth, nor grant bounties save with the approval of the Commonwealth. But generally they are free to legislate within the limits set by the overriding powers of the Commonwealth, and their laws can only be disallowed by the Imperial Government, and such disallowance would, it. may certainly be assumed, be based on Imperial, not on mere Commonwealth, grounds of disapproval. This undoubtedly puts the states in a much superior position to the provinces where the Dominion has a real and actual control over the provincial legislation on all topics whatever.

In matters of administration the state is quite free of even the amount of control exercised by the fact that the head of the provincial government is a nominee of and responsible to ciation v. New South Wales Railway Traffic Employés' Association, 4 C. L. R. 488.

(o) See 6 C. I. R., Part II. The doctrine of implied powers has been decisively negatived for Canada by the Privy Council (cf. Lefroy, op cit. pp. $665 \mathrm{seq}$.$) , and also for Australia, in Webb v. Outtrm, L. R. [1907] A. C.$ 81; but the High Court will, no doubt, persist in it.

(p) Constitution, ss. 114, 115, 117, \&c. As to discrimination by the Commonwealth, cf. s8. 51 (ii.), (iii.), ५9; L. R. [1906] A. C. 360. 
the Dominion Cabinet, while the judges are their nominees and removable by the Federal Parliament. The State Governor is still appointed directly by the Crown, and is responsible to the Imperial Government for his official actions. $\mathrm{He}_{\mathrm{e}}$ is directed in matters of imperial concern by constitutional practice to act independently of Ministers, but he has no formal obligation to act as a federal officer, beyond the somewhat vague duty of a Governor to look upon all matters from a wider point of view than from the mere immediate wishes of a State Government. The Governors correspond directly with the Secretary of State, and at each of the Conferences of Premiers, which are apparently to become a feature of state politics, great stress has been laid on this fact, and much satisfaction was expressed at the Conference in May, 1908, that the Secretury of State had telegraphed assurances that the reorganisation of his office by the creation of a Dominion Department would not interfere in any way with the direct correspondence with the State Governors, which would continue unless and until some alteration were rendered necessary by constitutional changes $(q)$. Of course, the Secretary of State reserves to himself the right of consulting with the Commonwealth if in any case he deems a state matter to affect the interests of the Commonwealth as a whole.

The difficulty of deciding what are Commonwealth or state matters remains very great. The complete divergence between the views of the state and the Commonwealth appeared in 1903 in the case of the failure of the Government of South Australia to comply with the request of the Dutch consul to effect the arrest of certain members of the crew of the vessel "Vondel," in accordance with the AngloDutch Treaty of 1856 . The Secretary of State applied for

(q) I.e., the reduction of the state to a pruvince. 
information as to the grounds of this refusal to the Commonwealth Government, but on the latter applying for information to the State Government the latter declined to gire any information save directly to the Imperial Government. The Secretary of State then asked the State Government for a report, and the matter, so far as action went, there ended. But a heated exchange of views passed between the Commonwealth and State Governments. It was laid down by the State Government that the only cases in which communications should pass through the Governor-General were cases in which the Commonwealth had power to deal with the matter in question, and such power only existed in regard to the transferred departments, and to matters as to which the Commonwealth had legislative power and had exercised it. In all other matters the state was the proper channel of communication. The government, therefore, held that as the Commonwealth had no specific power to legislate in treaty matters - the original power to do so having been left out of the final form of the Constitution, and the only power conferred relating to "external affairs" simply-the state alone could be responsible for the performance within its boundaries of treaties. On the other hand, the Commonwealth asserted that external affairs included treaties as the most natural part of its contents. The Imperial Government, in its reply, did not attempt to decide the question $(r)$ of the interpretation of " external affairs," but pointed out that the whole purpose of the Constitution was to create a single federation which should represent for all external purposes the Commonwealth, whether the actual purpose was a matter of federal or state legislative action, and that, therefore, all complaints by foreign powers should be forwarded through the Common-

(r) Cf. M'Kelvey v. Meagher, 4 C. L. R. 268 ; Quick \& Garran's notes on sect. 51 (xxix.) of the Constitution; Harrison Moore, Cunmonwealth of Australia, pp. 142, 143. 
wealth Goverument, to which the State Government was responsible. In all such cases the final responsibility lay with the Imperial Government, who were entitled to rely on the Commonwealth Government, and the Commonwealth Government were entitled to rely on the action of the State Governments, whatever the actual legislative powers of either might be.

The difficulty in this regard seems to be somewhat diminished, but the procedure observed in regard to eonsuls shows the complication of the present conditions. A consul is recognised not only by the Commonwealth, as in Canada by the federation, but also by each state in which he has consular authority, whereas in Canada the provinees are not required or asked to approve the appointments proposed, the full responsibility and anthority resting with the Federal Government. This is a striking example of the rather imperfect federation of the states, a federation which, as Mr. Chamberlain pointed out, would be reduced to a mere federal union if the views so ably urged by Mr. Jenkius on behalf of the South Australian Government had been accepted $(s)$.

There are many other points on which strife between the two parties seems almost certain, but in some eases it is hoped that discussion may obviate actual eonflict. In recent correspondence laid before the Commonwealth Parliament, and in the Premiers' Conference of 1908, reference was made to the extent of the legislative power of the Commonwealth in the matter of immigration; very diverse views showed themselves, but the Premier of Victoria was of opinion that the large power given by the Constitution would permit and, indeed, could only be properly exereised by the Commonwealth taking steps to resume lands on payment by voluntary arrangements, while the Premier of New South Wales was 
certain that the powers conferred by the Constitution were merely restrictive, allowing the Commonwealth to prevent the influx of unsuitable persons, but not to further the immigration of suitable persons; and the Prime Minister of the Commonwealth asserted that the power given covered advertising and so forth to induce immigration, but not power to take lands for their settlement. At the same conference there arose a discussion as to the question of honours, the Premiers being indignant at the alleged interference by the Federal Government in questions of state honours.

It is clear that the whole position is very difficult owing to the very imperfect nature of the Confederation Act, which leaves the matter in a confused position. The states, too, are undoubtedly hampered in their attempts at asserting their independence of federal control by the provision for the final right of the Commonwealth High Court to decide all questions of the rights inter se of the states and the Commonwealth, which the jealousy of the power of the Privy Council to decide cases led them to introduce into the federal Constitution. The judges of the Court are appointed by the Federal Government, they are all men who, in one way or other, have served the cause of federalism, and it would be absurd to assume that they can help being generally disposed to regard the federal compact as conferring on the central government all the powers which a true federation may have to exercise. If state rights were to receive adequate protection from the Courts, the proper method would have been to leave the control of the interpretation of the Constitution in the last resort in the Privy Council, which has, by its judgments, evolved a scheme of division of authorities from the provisions of the British North America Act, which, if not ideal, is still framed on broadly intelligible lines $(t)$.

( $t$ ) A good example of the difficult position of the Commonwealth is the 
It is probable that the near future will see some attempt to frame a federal Constitution for South Africa in place of the abortive Imperial Act of 1877 , which never came into operation. In that case it may be hoped that the arrangements aimed at by the Colonies will be rather on the model of those of Canada than those of the Commonwealth. It should, however, be noted that already in the Commonwealth the friction between the State Governments and the Commonwealth is giving rise to expressions of the desire to abolish the states as such and to create a great unified government, with a large number of district councils all over the country with purely limited powers to be exercised in subordination to the central Parliament. This alteration would require the amendment of the Constitution in many respects, but, though it is hardly yet within practical politics, it may be doubted whether the solution of unification would not be a wiser one in South Africa than that of federation with all the accompanying complications.

A word may be said on two experiments in the creation of quasi-Federal Governments, the one of which has disappeared for good, while the other formed the prelude to the more brilliant federstion of the Commonwealth. In 1852 the Parliament of the United Kingdom passed an Act which gave a representative Constitution to New Zealand, and, at the same time as providing for the creation of a full repre.

fact that in M'Kelvey v. Meagher, 4 C. L. R. 268, the Court held that the Parliament is not a central legislature, as contemplated in the Fugitive Offenders Act, 1881, and that, even if it could legielate on the subject under sect. 51 (xxix.) of the Constitution, still the states retained all their old powers in the meantime. Another point raised by the Premiers at the 1907 Conference was the landing of foreign troops. They claim to control it as a matter of policy, the Commonwealth as one of immigration or def nce or external affairs; and clearly it is both. The Conferences of Premiers are historically very interesting. Cf. the Conferences before federation, which rendered the Federal Council of little account, Harrison Moore, Commonwealth of Australia, p. 39. 


\section{RESPONSIBLE GOVERNMENT IN THE DOMINIONS.}

sentative legislature, they created six provinces $(u)$, which were each to have a special legislative body with limited powers of legislation.' Their laws could be disallowed by the Governor within three months of their receipt from the superintendent of the province, which provision practically excluded any power of disallowance by the Imperial Government, and preluded the surrender, in the case of Canada, of the power of disallowing such Acts in the case of the provinces. But the proviucial councils were entirely subordinate to the central government, for the colonial Parliament was entitled to modify or supersede any provincial enactment, and to modify the powers of any province without the approval of the Imperial Parliament, subject only to the usual control by Imperial legislation. This fact rendered the provinces merely glorified local boards, and under the authority of an Act of $1868(x)$, in 1875 the colonial legislature reduced them to this status by abolishing them, and creating such boards in their place in suitable districts $(y)$.

The other federation was that of the Federal Council of Australasia, created by an Imperial Act in 1885. It was to be composed of representatives, two each from $\mathrm{New}$ Zealand and New South Wales, Victoria, Queensland, South Australia, and Tasmania, and one each from Fiji and Western Australia, because of their status as Crown Colonies; numbers increased in 1894 by the Imperial Grovernment by Order in Council under the Act to five from each colony, not being a Crown colony. The subjects entrusted to the Federal Council were numerous and important; they included the relations of Australasia with the islands of the Pacific; the prevention of the influx of criminals; fisheries in Australasian

(u) $15 \& 16$ Vict. c. 72 , ss. $2-31$.

(x) $31 \& 32$ Vict. c. 92 .

(y) Cf. New Zealand Parl. Papers, 1876, A. 20. 
waters beyond territorial limits $(z)$; the service of eivil process beyond the colony in which it was issued ; the enforcement of judgments and of criminal process beyond the colony concerned; the custody of offenders on board colonial ships beyond the limits of territorial waters; any matter referred to the Council by Order in Council at the request of the Colonies; and any matters as to defence, quarantine, patents, copyrights, bills of exchange, weights and measures, marriage or divorce, naturalization of aliens, status of companies, referred by two or more Colonies, but so that any legislation on these topics would bind only the referring Colonies. The Council could also legislate in differences between Colonies if referred by both parties. The Act was, however, conditional on the Colonies deciding to pass Acts permitting their governments to send representatives, and despite its meeting four times and passing a good deal of legislation, which is still in force, being expressly saved in the Commonwealth Constitution Act, 1900 , its utility was mainly as an incentive to the Colonies to press on towards a more complete union $(a)$.

(z) Cf. the Acts passed to protect the pearl fisheries of Queensland (51 Vict. No. 1), of Western Australia (52 Vict. No. 1).

(a) Cf. Colonial Office List, 1902, pp. 1, 2; Harrison Moore, Commonucealth of Australia, pp. 30-39. New South Wales and New Zealand held nloof. 


\section{CHAPTER IX.}

IMPERIAL CONTROL OF DOMINION LEGISLATION AND

ADMINISTRATION.

The control exercised over colonial legislation by the Imperial Government takes two forms: either the colonial Act is never permitted to come into operation, or, if it becomes operative, is disallowed, or the Imperial Parliament itself legislates, thus removing all possibility of effective colonial legislation. In other cases, again, the imperial legislation is intended not to restrict colonial legislation, but to accomplish objects which, owing in the main to the territorial restrictions of colonial legislative power, are not within the competence of any colonial legislature.

All colonial Acts require the concurrence of the colonial Governor, as the representative of the King. In no case is the Governor bound to give such assent: he has an absolute discretion to refuse to assent to any and every Bill $(a)$, and in some cases he is bound to refuse to assent and to reserve the Bill for the consideration of the Home Government. This power of reservation is expressly given in the Constitutions of the various responsible government Colonies, with the exception of Newfoundland, in which the power is merely inferred, probably incorrectly, from the Royal Instructions to the Governor, by which he is forbidden to assent to certain categories of Acts unless a suspending clause is

(a) Practically this is never done save on ministerial advice. Cf. New Zealand Gazette, 1878, p. 912 ; below, p. 183. 
inserted, providing that the Act shall not come into force until the approval of the Crown shall have been signified in the colony. The power is a curious one, and has no exact counterpart in the English Constitution: it is not at home competent for the Royal Assent to be withheld for further consideration; le roi s'acisera was the appropriate term for the refusal of the Royal Assent. Nor is the Governor forbidden, over and above the power of reservation, to consult with the Imperial Government, before exercising his power to assent to, refuse assent to, or reserve, a Bill. There is no compulsion on the Governor to delay assenting : all that he is bound to do after a Bill is presented to him-and every Bill should be presented to him by constitutional practice immediately after it has passed both Houses-is to declare his intention as regards it with no more delay than is essential for the proper exercise of his duties as an imperial officer.

The Instructions given to the Governor are expressly contemplated in the Constitutions of every responsible government colony, except the Commonwealth of Australia, where the Governor-General is required $(b)$ to assent, refuse assent, or reserve a Bill, according to his own discretion, but subject to the provisions of the Constitution. That provision does not, however, exclude the sending of instructions $(c)$ to the Governor-General from the Imperial Government, because the Governor-General remains an imperial officer, and his instrument of office, the Royal Letters Patent constituting the post, require him to obey any instructions he may receive from his Majesty, that is, from the Home Government. Or, from another point of view, the discretion he is by law to

(b) Sect. 58 of Constitution. Cf. Parl. Papers [Cd. 4355], p. î.

(c) As suggested by Harrison Moore, Commonecalth of Australia, pp. 96, 97 ; cf. pp. 229,230 . Similarly a Governor may reserve on ministerial advice, see Parl. Papers [Cd. 3339]; contra, Todd, Parl. Goit., pp. 618-521.

K. 
exercise is not his personal judgment as an individual, but his judgment as an imperial officer.

The cases in which reservation is to take place may either be enumerated in the Constitution, or left to be set out in the Royal Instructions. The difference between the two methods of procedure is very considerable; in the former case the restriction prevents any law which may be assented to inadvertently having any legal effect; it can be successfully challenged in the Courts. In the latter case there used to prevail much doubt as to whether the restriction on the Governor's right of assent was merely a direction to the Governor, the breach of which made him liable to the censure of the Crown, or the omission of an essential part of the duty of legislation, which rendered the whole law invalid. The matter was finally cleared up only by the Colonial Laws Validity Act, 1865, which laid it down that the validity of any law should not be affected by disobedience of the Governor to any instructions given otherwise than in the Instrument of the Constitution authorising him to assent to laws. The modern rule, therefore, includes in the Constitution Act those cases of the highest importance, in which the reservation is urgently required, leaving to the Instructions cases in which less importance attaches to reservation. The latter course has the decided advantage of avoiding the difficult questions which might arise as to the validity of Acts which might be regarded as falling under the Instructions, but which in the particular case seems hardly of sufficient importance to need reservation.

The classes of Bills which a Governor is required by his Instructions to reserve vary somewhat. The following is the list as it stood in the Instructions of 1892 in the case of the Australian State (then Colony) Governors, and to New Zealand:-(1) Any Bill for divorce; (2) any Bill whereby any grant of money or land, or other donation or gratuity, is 
made to the Governor; (3) any Bill affecting the currenoy of the state; (4) any Bill imposing differential duties $(d)$; (5) any Bill affecting the control or discipline of the land or sea forces of the Crown in the state $(d)$; (6) any Bill the obligations of which are inconsistent with treaty; (7) any Bill of an extraordinary nature and importance, whereby the royal prerogative, the rights and property of British subjects not residing in the state, or the trade and shipping of the United Kingdom and its Dependencies may be prejudiced; and (8) any Bill to which the Royal Assent has already been refused, or which has been disallowed by the Crown. In addition, the Australian States Constitution Act, 1907, requires the reservation (e) of all Bills altering the Constitution of the legislature and the salary of the Governor.

Practically the same Instructions are in force in the Transvaal and the Orange River Colony $(f)$, with, in both cases, the additional Instructions contained in the Letters Patent, and therefore part of the law of the colony, that there shall be reserved any law by which persons not of European birth or descent may be subjected or made liable to any disabilities or restrictions to which persons of European birth or descent are not also subjected or made liable, and any laws affecting the Constitution of the colony. Both in these Letters Patent and the Australian States Constitution Act there are inserted provisions permitting. the Governor to assent, if he has previously received instructions to do so, in each particular

(d) Omitted in the State Instructions of 1900 , consequent on the legislative power in these matters being transferred to the Commonwealth. See Harrison Moore, Commonucalth of Australia, pp. 380, 381.

(e) Unless the Governor has received permission to assent, or unless the Bill is a temporary one and urgent. The Instructions permitted assent if the Governor had obtained pernission from the Secretary of State, or the Bill contained a suspending clause, or was urgent and not repugaant to the law of England or contrary to treaty.

(f) Instructions of Dec. 6th, 1906, and Jnne 5th, 1907. 
case through the Secretary of State. This provision is obviously convenient, though no provision is made to show how such Instructions are to be proved, and in certain cases the effect to be placed on the Instructions given might vary.

In Natal the list of subjects for reservation is the same as in the Transvaal and the Orange River Colony, but the rules are contained entirely in the Instructions of 1893 , and that relating to amendınents of the Constitution is omitted, though no doubt it would in any case of substantial alteration be adhered to. In the case of the Cape the list is further shortened by the omission of any reference to differential legislation against native races; the reason is that there is no distinction of colour in the Cape franchise, and that therefore the Imperial Government has not the same need to consult the interests of the natives. The Newfoundland Instructions of the 28th March, 1876, resemble those of the Cape, there being very few natives in the colony.

In the three remaining cases, those of the Commonwealth, Canada, and New Zealand, no formal Instructions at all are given to the Governors-General and Governor as to reservation in recognition of their status as Dominions. The alteration was made in the case of Canada, in the new Instructions issued in 1878 to the Marquess of Lorne $(g)$. It was argued by Mr. Blake, on behalf of the Canadian Government, that the power of reservation was undesirable, and that the constitutional relations of the Dominion and the Empire would better be maintained by the completion of legislation in Canada and disallowance afterwards, if such disallowance were deemed essential in the interests of the Empire. This argument was not fully accepted, since, in point of fact, the inconvenience of disallowing legislation actually in force is extreme, and would cause almost any Act

(g) Canada Sess. Papers, 1877, No. 13 ; 1879, No. 14, 181. 
to be accepted rather than invoke the disadvantages of upsetting a colonial law in operation, but it was felt to be unnecessary to specify the classes of Acts to be reserved, leaving the matter to decision in individual cases according to the importance of the Act in question for the Empire. Naturally the Canadian model was followed in the Instructions of 29th October, 1900, to the Governor-General of Australia, and in the new Instructions issued on 18th November, 1907, for the Dominion of New Zealand $(h)$. In one case, however, in Australia, reservation is essential under the Constitution Act (i), namely, in cases in which the Parliament limits the royal prerogative of granting special leave to appeal to the Judicial Committee of the Privy Council from the decision of the High Court of Australia, while in New Zealand, Bills amending the composition of the legislation require reservation under Imperial Act. In no case need a Canadian or Newfoundland Bill be reserved under the Constitution.

A reserved Bill in all cases, save those of Natal and Newfoundland, where no limit is fixed, must be assented to by Order in Council within two years from the date on which it was presented to the Governor for the Royal Assent, or else it becomes utterly null and void. If the Bill is required by an instrument having the force of law to be reserved and is not reserved, then the assent is a mere nullity, and the assent of the Crown can, as has been done in several Australian cases prior to 1907 , still be conveyed in the same manner as if the assent has not been given by the Governor, the Order in Council expressing assent merely reciting that the Bill had been presented to the Governor for his assent and ignoring the error made in assenting.

But even if an Act has properly, as far as legal reasons go,

(h) New Zealand Gazette, June 11th, 1908; Harrison Moore, Commonucealth of Australin, pp. 371-373.

(i) Sect. 74. For New Zealand, see $20 \& 21$ Viet. u. 53, s. 2 ; ubove, p. 90. 


\section{2}

RESPONSIBLE GOVERNMENT IN THE DOMINIONS.

received the Governor's assent, there remains to the Crown the power of disallowance within a period usually now limited to two years from the date of the Governor's assent. In the case of the Commonwealth, however, the period is one year, and in the case of the Australian States, the Cape, Canada, and New Zealand, the date runs from the date of the receipt of the Act by the Secretary of State, a reminiscence of the time when Australia and the Colonies generally were even further away from the United Kingdom than they are to-day. In Newfoundland, again, no limit of time for disallowance is prescribed, in accordance with the older practice, though the established custom is to disallow within the period of two years, which has become to some extent a sort of form in this connection. 'The time may seem somewhat long, but it has a real significance $(k)$. In any Act there is usually only one point or two which requires alteration, and the Imperial Government can ask for amendment in certain details, and the amendment can be carried out in the next Parliament, and the Royal Assent formally given to both Acts, while, if the Parliament will not amend, the Act can after all, if there be sufficient ground, be disallowed. It is on every account undesirable to disallow colonial laws, and often it is possible to secure suitable amendment.

The rules for reservation apply to laws passed by the Parliaments of the provinces of Canada, but the authority by which they are disallowed is the Governor-General in Council, instead of the Crown in Council, and the period allowed for disallowance is one and not two years. There have not, however, been apparently any Instructions issued to the Lieutenant-Governors as to the power of reservation, though the practice is usual to reserve Bills as to the constitutionality

(k) In the case of the Canadian provinces, the limitation to one year seems in practice decidedly inconvenient. For the Commonwealth, see Constitution, s. 59 ; and cf. $48 \& 49$ Viet. c. 60 , s. 18 . 
of which there may be doubt. In the earlier days of the provinces such Bills were much more common than they are now, and in New Brunswick and Nova Scotia several Acts have been vetoed by the Lieutenant-Governor on the advice of Ministers, who were anxious not in any way to run counter to the rights of the Crown in the Dominion Parliament (l).

In the case of Papua, the Lieutenant-Governor there has issued to him a set of Instructions based very closely on the Instructions given to the Governors of tropical Colonies in the control of the Crowu : at present and for a long time to come Crown colony government will be inevitable in that island, but the growth of a responsible government under the control of the Commonwealth will be of great interest. The same problem will probably be seen if the Commonwealth takes over the northern territory of South Australia; but there responsible government will begin at once, and a new set of problems will commence, unless the Commonwealth administers the country as a province.

In administration the control of the Imperial Government is naturally much less effective than in legislation, for which definite provision is made in the Constitutions of the Colonies, and for giving effect to which there are available the Courts of the Colonies and their power. In the case of executive action there is merely the Governor, who has no real control of any public officer, and who in effect cannot do any executive acts effectively without ministerial aid. The method in which a Governor can act therefore lies in his power of selecting a new Ministry, if he wants anything done, which of course is by no means always possible; or-what can always be done-by refusing to act at all, and so inducing Ministers to reconsider the position in cases where such reconsideration is possible.

(l) Todd, Parl. Goot.; pp. 587 seq. See 30 \& 31 Vict. c. 3, \&. 90. 


\section{RESPONSIBLE GOVERNMENT IN THE DOMINIONS.}

The degree to which the Imperial Government interferes $(m)$ in the affairs of a self-governing colony has steadily decreased, and now has probably reached its minimum, as it may safely be said that interference is so restricted as to render further restriction incompatible with the maintenance of the power at all. It would, of course, be a mere absurdity to assume that the interference practised in the early days of responsible government was erroneous or contrary to the best principles of responsible government. The process of growth was a slow one, and if the Imperial Government exercised in some cases a degree of control which was unnecessarily strict, the colonial Parliaments used to legislate with a light-hearted disregard of the possibilities of legislation which would now be regarded as at least as ridiculous as the over solicitude of the Imperial Government.

The lists of subjects mentioned above as requiring reservation in certain Colonies may serve as a convenient guide to the consideration of the gradual emancipation of the colonial Parliaments from imperial control over their legislation. The facts may be grouped under the heads there indicated, with the addition of that of the treatment of public lands, which has gained a new significance because of the revival of provisions affecting the control of the land policy in the new Colonies of the Transvaal and the Orange River. This topic may be considered first, and then in order those of (b) divorce legislation, (c) currency, (d) differential duties and trade relations, (e) merchant shipping, (f) military and naval matters, (g) immigration, (h) native policy, (i) legislation affecting the prerogatives of the Crown, and $(\mathrm{j})$ legislation affecting persons resident outside the Dominion.

(m) The converse is becoming more common. Contrast the reply to a resolution from Canada in favour of home rule for Ireland in 1882 (Parl. Papers [C. 3294]) with that in 1903 [Cd. 1697]. Moreover, more properly, the Cape and New Zealand objected to Chinese labour in 1904, but both these Dominions had sent troops to South Africa; see Chap. XVI. 
(a) In the Transvaal and the Orange River alone do any provisions on the subject of public lands attest the present interference of the Imperial Government. These provisions were regarded as necessary because of the fact that the land settlement policy was one directed in imperial interests, and not in any way desired by a substantial minority of persons in the Transvaal, and by the great majority of the people of the Orange River Colony. The settlers had great difficulties to face, they were in many cases not experienced in the peculiar troubles which attend a farmer in South Africa, and the great depression inevitable as the aftermath of war led to their getting deeper and deeper into difficulties. Due allowance for this fact was of course made by the government as long as the Colonies remained Crown Colonies, but there was naturally a risk lest when the government fell into the hands of those who were not in favour of the scheme originally, the settlers should be treated rather in accordance with their striet legal rights than in the somewhat generous manner in which they were dealt with by the colonial government. In both colonies there are, therefore, set up for five years boards, which will be appointed by and hold office at the pleasure of the Governor and will be quite independent of Parliament, having a staff entirely under the control of the board. For the time of its existence the board will be able to remit in any necessary cases instalments of purchasemoney, \&c., and generally act towards the settlers in the same way as did the colonial government under the old régime. But not only will the scheme come to an end at the termination of the fifth year from the initiation of the board, but arrangements may be made for the determination of the functions of the board at an earlier date, if the government of the colony, with the consent of the Governor and the approval of a Secretary of State, can make an agreement with the board for the settlement of the question. After either 
event the whole of the assets in the power of the board will be transferred to the Governor in council, that is, to the colonial Ministry $(m)$.

Save in these exceptional cases, the power of controlling the land policy of the Dominions has long since been renounced. It was, indeed, argued with considerable force in the early days of the colonisation of both North America and Australia ( $n$ ) that the duty of the Imperial Government was to keep the waste lands of the Colonies under its own control as trustee for future generations, and not leave the disposal of the natural resources of the Empire to the small bodies of settlers in the Colonies. But it was soon realised that the Colonies would not accept this mode of procedure, and that their development required them to be put in possession of the revenue to be derived from the lands, and in 1847 a full surrender was made of the lands of the Crown in the province of Canada, and in 1852 the right of the Colonies to appropriate the revenues of Crown lands was recognised by Act. In 1855, after much consideration, it was decided to entrust the responsible government Colonies of Victoria and New South Wales, Tasmania, and South Australia with the full power over the waste lands, and on the creation of Queensland in 1859 the same rule, of course, applied. In the case of Western Australia the Constitution Act of 1890 enacts that the whole control of the waste lands and the profits arising from them shall be vested in the legislature. Similar powers were conceded to the Colonies in South Africa on the grant of self-government, while it is significant that while Newfoundland possessed full control

(m) For the details of the lands and funds handed over to the control of the boards in either colony, see the Transvaal Letters Patent, Dec. 6th, 1906, Clause 52, and the Orange River Colony Letters Patent, June 5th, 1907, Clause 53.

(n) Cf. Journ. Royal Soc. of Arts, lvi. 337 ; Dilke, ibid. 344. 
over her lands, all grants of lands on the treaty shore up to 1904 were made subject to the treaty rights of the French, an example of imperial executive interference in a province long before generally surrendered to the colonial legislature and government on grounds of treaty rights. But in the Letters Patent of the Colonies, with the exception of those of Canada and the Commonwealth, the omission from the former being due, as usual, to the suggestion of Mr. Blake, the Governor is empowered to grant out the lands which may be lawfully granted by the Crown in the colony. As a matter of fact, this power, if ever used, would be exercised entirely on ministerial advice, but in the Dominions the system of granting land is minutely regulated by Act, so that little or no action is ever taken under the Letters Patent (o).

(b) In the case of dirorce there is a real meaning in the provision for reservation even at the present day, when the old practice of endeavouring to regulate the marriage law of the Colonies in harmony with the ideals of the United Kingdom has disappeared. At that time Deceased Wives' Sisters Marriage Bills were freely disallowed on grounds which were certainly inadequate; but the whole question was finally settled by the decision, first, not to disallow such Bills, then in $190 b$ to legislate in the Imperial Parliament to remove the one disability attaching to children of such marriages in the United Kingdom, viz., inability to inherit land $a b$ intestato, and finally, in 1907, the recognition of such marriages as legal in the United Kingdom. But, in the case of divorce, there would be obvious objections to the carrying out of a policy of divorce in the Colonies which would result in the existence of a large class of persons who were legitimately divorced according to colonial law, but not so

(0) Cf. Constitution and Goternment of New Zealand, p. 179, n. 3; The Queen v. Clarke, 7 Moo. P. C. 77 ; The Queen v. Hughes, L. R. 1 P. C. 81. 
according to English law. By the strict rule of the English law that domicile is necessary to give divorce jurisdiction, a colonial Court can only in the eyes of the English law divorce persons domiciled in the colony, so that if colonial laws permit the divorce of persons not so domiciled, the persons concerned, if they remarry, will be liable to prosecution for bigamy in England under the Act 24 \& 25 Vict. c. 100, s. 57, just as much as people who obtain divorces in foreign countries in which they are not domiciled. As a matter of fact, up to the present the divergence between the classes of cases in which the colonial Courts will grant divorce and those in which the English Courts will do so is not serious as regards domicile; the substantial difference lies only in the development given in the Acts and in the Courts of Australia and New Zealand to the doctrine of the deserted wife whose husband has changed his domicile. It is now apparently established law all over the Australasian Colonies $(p)$ that the Courts will regard such a wife as retaining her domicile for purposes of divorce at least. But it remains to be seen how far that view will be carried. It can be supported on various grounds: it may be held that there is no evidence before the Court in such cases to prove the change of domicile, since the usual form of the action is merely proof of desertion, and there is no need to assume anything in favour of a defendant in such a case. Moreover, the English law on the subject mainly consists of dicta, none of which are conclusive in the matter. In other respects the Colonies go far beyond the divorce law; but no interference is practised with their laws on that ground, as it must be a matter for the local parliament to decide how far they will preserve the sanctity of matrimonial relations, and the law of England

(p) But cf. Parker v. Parker, 5 C. L. R. 691; Murphy v. Mrurphy, 1902 [T. S.], 179, which assert the doctrine of domicile. Contra, Armstrong v. Armstrong, 11 N. Z. L. R. 201. 
allows divorce to be for any reason sufficient in the Courts of the husband's domicile $(q)$.

(c) The question of currency is one of peculiar imperial importance, and is further reserved for the imperial control, because it affects a prerogative of the Crown, which, not being of a properly legislative nature, can be and has been exercised in Colonies where the Imperial Crown has no power of legislation. The prerogative has been, however, ever since 1870 converted into a statutory power by the Coinage Act of that year, sare in respect of India and Canada. Except in India, the only coins issued in the Empire are those struck at the Royal Mint in England, or at the three Australian branches at Perth, Melbourne, and Sydney, or at the newlycreated branch in Canada at Ottawa, the Colonies paying the expenses of the maintenance of these branch mints, which are, however, under the sole control of the Imperial Government through the Royal Mint. It is now contemplated to mint silver token coins at the Australian mints. Up to the present such coinage has always been minted in England, the profits accruing to the Imperial Grovernment, which, however, has the responsibility for the regulation of the coinage generally, and the replacement of light coins, gold or silver. For British Dominions which use other than ordinary coins, the supplies are made by the mint, the colonial government in that case paying the expenses and receiving the profit. Any colonial Parliament might legislate on this question, but no such legislation has taken place since 1870, even in the Commonwealth of Australia, which is perhaps of all Parliaments most jealous of its powers; while in 1905 a Transwaal Act.which purported to regulate coinage, though not containing anything incorrect in point of principle, was disallowed on the ground that the more proper procedure was by Order

(q) Cf. Dicey, Conflict of Loucs, pp. 805, $838 \mathrm{seq}$. 
in Council under the Coinage Act, 1870, and a much more objectionable Canadian Act was disallowed in 1851. The Federal Acts of 1868 and 1871 preserve the royal prerogative intact $(r)$.

(d) As regards the imposition of differential duties, the control of trade was originally contemplated to be reserved in the hands of the Imperial Government. It was, indeed, one of the few points which Lord Durham in his famous report assumed would be kept in the hands of the Home Government, and as late as 1842 that government framed a tariff for Canada. But everything was changed by the introduction shortly afterwards of the principle of free trade, which rendered it necessary to leave to the Colonies full freedom of action. Accordingly, in 1846, an Act was passed by the Imperial Parliament to enable the Colonies in North America to reduce or repeal duties placed on foreign imports by Acts of the Imperial Parliament. In 1849 this concession was followed by the repeal of the Navigation Acts, which restricted the trade of Canada, and in 1857 and 1869 full power was given to colonial legislatures to regulate their customs establishments and the coasting trade. At first, however, the Home Government was unwilling to adopt the principle of intercolonial preference either in Australia or in North America, and it was not until $1861(s)$ that the principle of intercolonial preference was allowed in North America, and until 1873 that it was sanctioned in Australia $(t)$, while the last remains of the restrictions on differential duties imposed by the Constitution Act of 1850 on the Australian Colonies only disappeared under an Imperial Act of 1895. In 1859 occurred the last attempt to intervene in the matter

(r) Canada Sess. Papers, 1870, No. 40 ; cf. Jenkyns, British Rule and Jurisdiction beyond the Seas, pp. 28 seq. ; Chalmers, Colonial Currency, Chap. II.

(s) Cf. Canada Sess. Papers, 1869, No. 47.

(t) 36 \& 37 Vict. c. 22 ; Parl. Papes's [C. 576], [C. 703]. 
of the Canadian tariff, when the Canadian Government declined absolutely to permit interference unless the Home Government were prepared to undertake the responsibility of the administration of the country $(u)$; while in $18 i 9$ the Home Government recognised the sole right of the colonial Parliament to decide upon a protective tariff, and were prepared to assent to a reciprocity treaty with the United States, had that Power been willing to arrange one $(x)$.

Despite the disappearance of these formal restrictions on the freedom of colonial action the Imperial Government has established the doctrine $(y)$ that no colony shall accord to any foreign country any preference which she will not also accord to the British Dominions, while no colony shall accord to any other colony any privileges which are not also accorded to the United Kingdom. Accordingly in 1890 the Home Government, while permitting the negotiation of a treaty between the United States and Newfoundland for the grant of mutual preference, declined ultimately to ratify it, because of the protest from Canada that the passing into force of the treaty would prejudice the Dominion in its efforts to secure a similar treaty with the States. In 1902, however, the government had altered its attitude to the extent of being ready to allow the ratification of a similar treaty concluded in that year with the States, despite the fact that its coming into operation might have been prejudicial to the interests of Canada, on the ground that it would not be justifiable to sacrifice the interest of the one colony to the other; but the United States Government did not ratify the treaty $(z)$.

The principle also received full approval at the conferences

(u) Honse of Commons Papers, 1864, xli. 79.

(x) Parl. Papers [C. 2305], [C. 2369]; Canada Sess. Papers, 1569, No. 47.

(y) Parl. I'apers [C. 78:4], Lord Ripon's desp. 28th June, 1895.

(z) Parl. Papers [C. 6303], for the arrangement of 1890 ; [Cd. 3262], pp. $51 \mathrm{siq}$., for that of 1902. 
of 1894 and 1902, where also the doctrine was laid down that efforts should be made to leave the Colonies free to conclude what arrangements they liked with the mother country and each other in tariff matters, without having to make the same concessions to foreign Powers. This led, in 1895, to the removal of all restrictions on the levy of differential duties in the Australian Colonies, and to the denunciation, in 1897, of the Belgian treaty of 1862 and the German treaty of 1865, under which the Colonies were bound to give these Powers and, necessarily, all most favoured nations, the same concessions as might be accorded to the mother country $(a)$. Under these principles there have been granted preferences to the United Kingdom by Canada, the South African Customs Union in 1903, and, in the same year, by New Zealand, and also, in 1907-8, by the Commonwealth of Australia.

Another application of the same principle may be seen in the recent Canadian action arising out of the treaty of 1907 with the French Republic. As soon as it comes into effect, a Canadian Act of 1908 provides that all the privileges granted to France will be automatically extended to the British Empire without conditions, while the tariff concessions made to France are so limited as to injure as little as possible British trade. Similarly, the customs agreement between South Africa and New Zealand gives the contracting parties no higher privileges than are accorded gratis to the United Kingdom.

(e) In the matter of merchant shipping full power was given to the Colonies to regulate their coasting trade as far back as 1869, and that power has also been given, since 18:j4, in the case of vessels registered in the colony $(b)$. These powers are extended in all cases by the right, under sect. 478

(a) Parl. Papers [C. 9423], [Cd. 1630].

(b) See now sects. 735 and 736 of Merchant Shipping Act, 1894. 
of the Merchant Shipping Act, 1894, to apply certain provisions of that Act to vessels trading with the colony to which the provisions in question would not otherwise apply, and the whole series of powers gives the colonial legislature full control over all shipping which can be called local. Moreover, the Merchant Shipping Acts of the United Kingdom give the local government full power over all matters of importance, such as the securing of the seaworthiness of vessels trading to the colony, and so forth. The principle has been that the Imperial Government reserves to itself the right to control vessels on the high seas, while leaving to colonial control the management of vessels which are really local. Claims have, however, been put forward recently by colonial legislatures to control all vessels which trade with the colony. The New Zealand Parliament has legislated, making vessels which trade with Australia and the Western Pacific fall, in certain respects, under the control of the Dominion Parliament; while the Narigation Bill, as introduced into the Commonwealth Parliament in 1904, was calculated to assert in many respects full control over all ocean-trade ships. The outcome of a long correspondence between the Home and Colonial Governments on the matter was the holding of a conference between representatives of the three governments concerned in London in 1907, when various principles were agreed on in order to minimise the likelihood of the conflict of the legislatures. It was agreed that the regulation of the coasting trade included the power to regulate, in shipping matters, any vessels which took up cargo or passengers at an Australian port or Now Zealand port in order to set them down at another port in the same colony, except only in such cases as the passengers or goods might be being conveyed on through tickets from oversea. In addition to vessels engaged in the coastingtrade while so engaged, the colonial legislatures were also 


\section{RESPONSIBLE GOVERNMENT IN THE DOMINIONS.}

to control all vessels registered in and trading to the Colonies, leaving to the Imperial Parliament the control of all other vessels, including vessels whose trade was purely oversea trade and coasting vessels, after they had left the colonial waters. This arrangement excludes from the power of the colonial legislatures all vessels trading merely between the Colonies of Australia and New Zealand and the Pacific Islands, unless they actually engage in the coasting-trade. In the case of vessels subject to the legislative powers of the Colonies, the Merchant Shipping Act, $1894(c)$, requires that there should be made no difference between the vessels registered in the colony and other British vessels, and the conference accepted this principle, together with the other principle that in no case should foreign vessels be placed in the British Dominions in more favourable position than British vessels $(d)$. The question of legislating on the lines of these resolutions is still under the consideration of the Dominion Governments.

In one respect a somewhat extraordinary power has been given to Australia-the right to enforce the laws of the Commonwealth as a whole, and not merely those referring to matters of shipping, on board every British vessel whose first port of clearance and port of destination are in the Commonwealth. The exact force of this provision has just been decided to be to put the laws of the Commonwealth in force on every vessel which goes on a round journey (however far afield) from one Australian port to another $(e)$.

(f) While the control of the Imperial Government in matters of trade and shipping remains a living factor in the

(c) Sect. 736 .

(d) Parl. Papers [Cd. 2483], [Cd. 3023], [Cd. 3826], [Cd. 3891], [Cd. 4355]; for the conference [Cd. 3567]; and see my article, Journ. Soc. Comp. Leg., 1908.

(e) Merchant Service Guild of Australasia v. Archibald Currie Prop., Ltd., 5 C. L. R. 737 ; cf. $63 \& 64$ Vict. c. 12 , s. 5 ; $48 \& 49$ Vict. c. 30 , s. 20. 
relations of the colonial governments and the Imperial Government, the control of the latter over military and naval affairs has steadily dimiuished $(f)$, until it is now no more than a right of advising colonial governments, when that advice is asked for. In time of war the situation would be, of course, entirely altered, if the course of events should cause the colony concerned to become involved in hostile operations. The command of the colonial forces would then doubtless be conferred on the imperial officer sent out to command the regular troops employed in the colony. Power to do this exists in all the self-governing colonies which maintain military forces. On the other hand, the power would only be exercised on the advice of Ministers. It would be impossible to exercise such a power against the wish of a colonial Ministry. If the war did not result in the employment of military forces from the United Kingdom, the control of the local forces would, of course, rest with the local government exactly as in time of peace, though the local government would no doubt consult with the Imperial Government as to the use to be made of its forces in the conduct of the war. Further, in case of a war in which the local forces could be spared, part thereof and any volunteers who might desire to serve with the imperial forces would be allowed by the local goverument to join these forces and to serve under the command of the imperial officers commanding.

This state of affairs is fully recognised by the Army Acts of the Imperial Parliament. A colonial force is governed solely by its own colonial law, even when on active service with the imperial forces, unless the local law makes no provision for the discipline of the troops when on such active service, in which event the provisions of the Army Act

(f) Cf. Harrison Moore, Commonvealth of Australia, p. 222; and cf. the position of the Crown towards the army at home claimed in Queen Victoria's Letters, iii. 296, 297. 
apply $(g)$. This is a case where colonial legislation is given by Imperial Act an extra-territorial operation, as otherwise the local Act could merely govern the acts of the troops within the colonial limits themselves. There are, however, obvious advantages in securing similarity of law for all troops on active service, and possibly this may be arranged by simultaneous legislation in the several colonies or by imperial legislation with the consent of the Colonies $(h)$.

Some modern illustrations of usage may be given. We may regard as completely antiquated the claim of the New Zealand Government in 1864 to exercise command over the actions of the imperial troops situated in the colony. The Imperial Grovernment then emphatically repudiated the theory that any colonial government could control imperial forces, and entered shortly afterwards in a resolute effort to induce the colonial governments to supply themselves with forces of their own, or at least to pay the cost of the colonial establishments of imperial troops. This course received the formal approval of the House of Commons on 4th March, 1862, when it was resolved that while the House fully recognised the claims of all portions of the British Empire to imperial aid in their protection against perils arising from imperial policy, it was of opinion that selfgoverning colonies should undertake the main responsibility of providing for their own internal order and defence, and ought to assist in their own external defence. As a result, in 1873, the Under-Secretary of State for the Colonies was enabled to say in Parliament that the garrisons in the Colonies were almost entirely maintained for imperial pur-

(g) Army Act, 1881, s. 177. On the other hand, the Army -Act alone regulates the conduct of imperial forces engaged in operations in the colony, though colonial legislatures, under sect. 169, have a limited power of suiting minor provisions of the Army Act to the circumstances of the colony.

(h) Cf. Australia Defence Act, 1903, s. 55 ; Canada Militia Act, 1904, s. 74 ; Natal Militia Act, 1903, s. 57. 
poses. There are still, however, imperial garrisons in South Africa, due primarily to the need of securing the tranquillity of the Colonies from native insurrection, and only in a very secondary degree required against foreign attack. On the other hand the Canadian Government has assumed the full responsibility for the garrisons of Halifax and Esquimalt, which up to the time of the South Africun war were always garrisoned by imperial troops, as part of the imperial defence system (i).

The necessity of the Governor acting on ministerial advice, in the matter of placing the colonial forces under the command of the imperial officer commanding in South Africa, was strikingly illustrated in the case of the dispute in 1877 and 1878 between the Governor of the Cape and the Molteno Ministry $(k)$. The latter asserted that the Governor was bound to accept the advice in military matters of his Ministers, and proceeded to invest the local commandant with full powers of independent action, denying the right of the Governor to interfere, and in particular to place the colonial forces under the command of the officer commanding the imperial forces $(l)$; indeed, they deprecated the use of the imperial forces at all, as tending to depress the colony, under the apprehension of imperial domination. The Governor, in view of the refusal of the government to accept his advice and their insistense on acting as if he were a cypher, declining to resign, and declaring that they alone were responsible to Parliament, decided

(i) Parl. Papers [Cd. 2565]. With the disappearance of imperial troops the administration of the government, in the Governor-General's absence, has passed to the Chief Justice.

(k) Cf. Harrison Moore, Commonvealth of Australia, pp. 221-223; Todd, Parl. Goot. pp. 380 seq.

(l) The power is given in Australia, by the Defence Act, 1903, s. 53, to the Governor-General, not the Governor-Geueral in Council, and so with other Acts. But this has no special significance. 


\section{RESPONSIBLE GOVERNMENT IN THE DOMINIONS.}

to dismiss his government and to appeal to the people. Fortunately, the new government under Mr. Sprigg succeeded in obtaining a parliamentary majority and so vindicated the action of the Governor, which also received the full approval of the Secretary of State, who laid stress on the fact that the Governor, as High Commissioner for South Africa, had a responsibility greater than that of Ministers, which should have inclined them all the more to accept his advice in a matter in which great interests were involved, and when success in the war against the Kaffirs could only be expected from unity of counsels and efforts. On the other hand, the constitutional doctrine seems to be clear that the use of colonial forces can only be carried on with the assistance of Ministers, and this view was asserted both by the new government in the House, when the Opposition, under Mr. Merriman, made an attack on the action of the Governor, and also by Sir Bartle Frere himself, who expressly rested the justification for his action on the principle of the constitutional power of the Governor to inform Ministers that they have lost his confidence and to summon other Ministers to office, subject to the necessity of their securing the support of Parliament. In accordance with this rule, the colonial forces in the South African war, both in the Cape and Natal, were placed under the imperial direction by the advice of the colonial governments. It might, indeed, be argued that in such a matter the Governor must be entitled on imperial grounds to overrule Ministers, even if he cannot find another government; but this doctrine would involve the theory that the Imperial Government could insist on colonial forces taking part in a war, a doctrine opposed to the fundamental principles of self-government, which leaves it to a colony to decide how far it will participate in wars due to imperial policy. Of course, the Imperial Government need not defend a colony which will not co-operate to save itself, but 
that is a different matter from claiming a power to make a colony defend itself under imperial direction $(m)$.

The South African war affords, also, instances of the raising of troops for voluntary service with the imperial forces in the Colonies, a practice which also was seen in the Egyptian Expedition of $1885(n)$, and offers of which were made in 1878. Further permanent provision for the criticism of colonial schemes of defence has been made by the creation of a permanent organisation-the Colonial Defence Committeewhich receives reports on the defence of the several Dominions, and, in accordance with the wishes of the colonial governments, offers freely comments on any questions of importance. The Committee works in co-ordination with a still more authoritative body-the Committee of Imperial Defence (o)-which was inaugurated hy Mr. Balfour's Ministry, and which is marked out by the fact that the Prime Minister $(p)$ himself presides at the meetings, and thus becomes acquainted at first hand with the problems of the military defence of the Empire. Moreover, the constitution of the Committee is elastic, and permits the addition of colonial members whenever any matter affecting the Colonies is under discussion.

Another means by which the colınial governments are kept in touch with the imperial military organisation is in the fact that the officers commanding or inspecting the troops of the Colonies are often selected from the British army. This arrangement, in the case of Canada, at one time took the shape that the Militia Act rendered obligatory on the government the appointment of a British officer to command the forces. This plan did not work satisfactorily, as the

(n) Parl. Papers [C. 2079].

(n) Ibid. H. C. 207, 1884-85.

(o) Anson, Law of the Constitution, II. i. 136.

(p) Hansard, 4th ser. cxxxix. 69 sey., 619 seq. ; cxlii. 62 seq. 
officer always had difficulty in realising his position as servant for the time being of the colonial government and not an imperial officer. In the result, after much friction, the Dominion Government in 1904 dismissed by Order in Council the then commander, Lord Dundonald, as in his eagerness to secure the efficiency"of the militia, he had made what practically amounted to attacks on the Dominion Government. In the place of the office of General Officer Commanding was instituted that of a Militia Council with an Inspector-General, who may be either appointed from the Canadian or from the British army. A similar Council has been instituted in New Zealand since 1906, and one of the members is an officer from the British army, whose experience is thus freely put at the use of the Dominion Government, while the post of General Officer Commanding has been abolished. In 1901 the Commonwealth Government appointed General Hutton to be General Officer Commanding the Commonwealth forces, but the same fatality which seems always to have accompanied that office fell to his lot, and in 1905 the post disappeared, a Board of Defence taking the place of the General Commanding $(q)$. In the Cape and in Natal the colonial forces are now commanded by colonial officers.

In the event of the conduct of military operations by a colonial government within the colony for the preservation of internal order, the Imperial Government will assist if necessary, but in that case it necessarily obtains the right to interfere in the terms of settlement of the question concerned. This was the case in New Zealand as long as the wars against the natives there were conducted with the help of imperial troops, and similarly in the case of the disturb-

(q) Proposals for compulsory naval and military service are now under the consideration of the Commonwealth Parliament, which contemplate that, if volunteers from Australia engage or active service abroad with the imperial forces, they will fall under the Army Act, 1881 ; see Parliamentary Debates, 1908, Nos. 8 and 9. 
ances and wars in South Africa. In the case of Basutoland, annexed in 1871 to the Cape, disturbances became acute in and after 1878, when the Cape Government endeavoured to enforce the disarment of the tribes. In this attempt they practically failed, and peace was only restored on the mediation of the Home Government, resulting in the disannexation of Basutoland and the coming of the Basutos under the immediate control of the High Commissioner for South Africa. In the case of the native rebellion in Natal, which broke out in 1906, the Imperial Government were prepared to give help if necessary, but active assistance was not required, though in fact the Imperial Gorernment did afford help by keeping all their forces still in the colony where their presence assured the rebels that in the long run the Natal Government had the support of the Imperial Government. It is indeed impossible in fact, however much so in theory, for the Imperial Government to dissociate itself from the Colonies, and therefore in the long run, however much it may dislike the responsibility, the burden of any colonial military action may fall upon it. The same consideration applies with greater force to naval arrangements, and while local navies cannot be considered other than valuable, it is essential that the Colonies should consent in time of war to put their fleets under one central control. This point is insisted on by the Admiralty in the recent correspondence regarding the Australian naval agreement, and is the only constitutional consideration involved $(r)$.

(g) One other great sphere of imperial responsibility is immigration, especially that of coloured races into the Empire. There exists at present in all the Dominions the most pronounced dislike of any considerable oriental immigration into these colonies-a dislike based in part on economic

(r) Parl. Papers [Cd. 4325]; see Commonwealth Parliamentary Debates, 1908, pp. 1320 (Mr. Deakin), 1459 (Mr. Fisher). 
grounds, for the oriental is willing to work at wages which the white population of the Colonies deems inadequate for a decent standard of life; partly on social grounds, for the oriental is a mystery to the occidental; and partly on colour prejudice. The existence of the feeling is to a great extent natural and inevitable. The population of all the Dominions is, without exception, small, and in the case of Australia grows very slowly, so that there is real danger to the purity of the race, and, indeed, even to its supremacy, if uncontrolled immigration takes place. On the other hand the action is one decidedly unfriendly to the great coloured peoples, and in particular it is hard to reconcile the exclusion of British Indians with any theory of imperial citizenship. The first effects of the feeling made themselves apparent in legislation against Chinese in Victoria in 1855, but in the sixties and seventies the exclusion feeling seemed to be dying away, until it revived with great vigour in the eighties, culminating in various illegalities both in Victoria and New South Wales and leading to a general discussion of the subject by a conference of Australian premiers, which led to uniform exclusion legislation all over Australia and New Zealand $(s)$. In 1885 and $1886^{\circ}$ similar legislation was passed in Canada to protect British Columbia, but really prohibitive legislation did not become necessary until 1900, when the tax on each Chinese introduced was fixed at a hundred dollars, and 1903, when it was increased to five hundred dollars, while further restrictions were imposed in 1908. The action taken in these years was the outcome of the report of a commission which made a most exhaustive investigation into all the circumstances and reported very decidedly against the permission of

(s) See Mr. Jebbs' paper in Journ. Royal Soc. of Arts, lvi. 585 seq.; Parl Papers [C. 5374], [C. 5448], for Chinese in Australia and Canada; [C. 8596], for Colonial Conference of 1897 ; [Cd. 2105], return of laws. 
further Asiatic immigration. As China has no treaty right - the treaty of Pekin of 18611 is unilateral-to have its subjects enter the British Dominions, the exclusion, if harsh, was at any rate free from any violation of treaty, and the Imperial Government consistently declined to interfere with it. Largely on the Canadian precedent, Chinese exclusion Acts have been passed by the Cape in 1904 and by Newfoundland in 1906, and the New Zealand legislation has been strengthened by Act No. 78 of 1907 .

More general exclusion legislatiou has been based on the principle accepted by $\mathrm{Mr}$. Chamberlain in 1897 at the Colonial Conference. It was then laid down that the proper mode to secure the exclusion of undesirable immigrants was a dictation test in a European language, and after the conference the several Australasian colonies which had passed Bills of a different character which had failed to secure the Royal Assent hastened to adopt similar legislation-New Zealand in 1899, New South Wales and Tasmania in 1898. The Cape legislated to the same effect in 1902, Natal again in 1903, the Transvaal in 1907, and the Commonwealth of Australia in 1901 and 19u5. In the case of the Commonwealth protest was made by the Japanese Government because the act was stated in Parliament to be directed against the Japanese ; but in reply it was pointed out that the legislation did not in any way discriminate against Japanese and the law was not disallowed. But the Commonwealth Government in 1905 altered the law so as to omit any express reference to a European language, thus removing any formal ground of complaint $(t)$.

Canada has remained outside this legislation and has steadily counteracted the efforts of British Columbia to pass

(t) Cf. also the protest of the Indian Government against the excluaion of Lascars from ships carrying the mails under subsidy, Parl. Papers [Cd. 1639]. 
Acts on the Natal model. On the other hand, difficulties have arisen through the unconditional adherence of Canada in 1906 to the Japanese treaty of 1894, under which the two Powers stipulate for the free entry of subjects of either country into the territories of the other. By an arrangement in 1907 made at Tokio by the instrumentality of the ambassador and the Canadian Minister, Mr. Lemieux, the Japanese Government has agreed to secure that immigration shall not be of such a character as to embarrass the Canadian authorities $(u)$. The still more important question of the entry of British Indians has been settled by negotiations with the Imperial Government, under which the Canadian Government has decided to order that henceforth all Asiaties immigrating must have at least $40 \mathrm{l}$. in their possession on landing to prevent their being left stranded in a country where the climatic conditions are not especially favourable, and where the prejudice against their employment is steadily increasing $(v)$. In their reports the Canadian Government emphasise the duty of considering and aiding the Imperial Government in framing their policy.

But even when the Asiatic is allowed to immigrate, there is a tendency to subject him to differential legislation, especially in respest of factory $(x)$ Acts and political privileges, of which he is deprived both in Western Australia and in the Commonwealth. In this respect there has been considerable difficulty with Natal. In that country there are a very large number of Indians, introduced for the purpose of the sugar fields, under contract, who have, on the completion of their indentures, settled in the country. After the grant of responsible government, steps were taken by Acts of 1894

(u) Canada House of Commons Debates, Jan. 28th, 1908.

(v) See Mr. Mackenzie King's Report, 1908, presented to Canadian Parliament; Sess. Papers, No. 36A ; Purl. Papers [Cd. 4118].

$(x)$ For a curious debate on this point, cf. Western Australia Parliamentary Debates, 1905, pp. 98-117. 
and 1896 to exclude the Indians from the franchise, on the ground that they were not persons accustomed at home to representative institutions. In 1895 an effort was made to secure that all Indians thereafter introduced under contract should return home after the expiry of their indentures or enter upon fresh contracts, but the Indian Government intervened, and insisted on their being allowed to stay if they paid a licence fee of $3 l$. In 1897 the issue of trading licences was confined to persons able to keep books in English, and the appointment of licensing officers was given to local councils, from whose decisions there could be no appeal. Other similar legislation followed, and finally the Parliament has endeavoured to deprive by a Bill of 1906 the Indians of the franchise for municipalities, and the latest legislation proposes that further immigration shall cease, and that all trading licences granted to natives shall be cancelled on compensation. These proposals are still under consideration, and have not yet $(19() 8)$ been sanctioned by the Imperial Government.

In the Transvaal and the Orange River Colony the old legislation against Asiatics is still largely in force, and the latest legislation, that of 1907 , has forbidden any future entry of British Indians; the Imperial Goverument has allowed the Act to become law in the hope of thus securing better terms for the Indians already there domiciled, and it is believed to be possible to secure the entry of a limited number of physicians and priests by executive action. But the problem of immigration is far from being settled $(y)$.

(h) Nor is the complication less in the question of natice policy. In Australia the matter is not of importance, save in Western Australia, where, after the grant of self-govern-

(y) Parl. Papers [Cd. 3887]; Dicey, Law of the Constitution, p. 116, n.; also, on minor disabilities, cf. Sonnadere v. Municipality of Perth, 1 W. A. I. R. 61 . 
ment, for a time an effort was made to secure the control of the native department by placing it under the direct control of the Governor independently of any Minister, and making an appropriation of $5,000 \mathrm{l}$. for its expenses (z). But the plan did not work well; the rest of the government looked with disfavour on the separate department, and the Ministers made a series of attempts to induce the Secretary of State to agree to the placing of the department under ministerial control. For some years this request was postponed, but effect was given to it in $\mathbf{1 8 9 7}$ after a discussion of the matter with the Premier at the Colonial Conference, and the department became part of the ordinary administration, a definite appropriation being made towards its expenses, which are not, therefore, subject to an annual vote (a). In New Zealand, for a few years after the grant of self-government, the Imperial Government retained native policy in its own hands, but in 1863 the full control was handed over to the government, which has distinguished itself by its wise efforts to benefit the native race, and which has provided for its representation in the colonial Parliament $(b)$, and, if desired, on the executive Council. In Canada a separate department and vote lasted down to 1861 , but after that the control was left with the colonial governments, and on federation the Indians became the care of the Federal Government, which has instituted a native department to control them, and whose management of the Indian question has added greatly to its prestige. Newfoundland has a number of Esquimos in Labrador to care for, as far as the small resources of the colony allow; steps have been taken to introduce reindeer for their benefit, and the government does all it can for the people.

(z) Constitution Act, s. 70 (schedule to 53 \& 54 Vict. c. 26).

(a) Parl. Papers [C. 8350].

(b) Cf. Act No. 101 of 1908, s. 180 ; No. 22 of 1908, sched. 
But the real difficulties of the problem appear mainly in South Africa, where the native population is large and steadily on the increase. In the case of the Cape, the relations of the governments have been on the whole satisfactory, and the Cape consented to give back to the Imperial Government the one province, Basutoland, which she was unable to manage successfully. In Natal, however, the matter has not gone off so smoothly. It was considered necessary to instruct the Governor in native affairs to act on his own judgment, but he was given no department to aid him, and practically he has had to follow ministerial advice. In 1897 the province of Zululand was handed over to the government of Natal on condition that a commission should delimit the native lands, which were not to be disturbed save by the consent of the Imperial Government. At the same time, the Imperial Government stipulated that Uinizulu should be brought back to Natal and made a chief, on conditions which were not to be altered without the consent of the Imperial Government; but this agreement has formed the subject of some misunderstanding. The report of the Natal Native Affairs Commission was adverse to the character of the government in Natal as regards native affairs, and alterations are under consideration $(c)$.

In the Transvaal $(d)$ and the Orange River Colony $(e)$ the interests of the natives are to be secured by the provision that the Governor shall retain all the powers of supreme or paramount chief, and that their lands shall only be alienated

(c) Parl. Papers [C. 8782] (aunexation to Natal of Zululand), [Cd. 3888]. [Cd. 3889], [Cd. 4194], [Cd. 4195], [Cd. 4328]. Cf. Dilke, Journ. Royal Soc. of Arts, lvi. 344 ; Hansard, 1908, exc. 102 seq.

(d) Letters Patent, Dec. 6th, 1906, s. 51.

(e) Letters Patent, June 5th, 1907, 8. 52. In all three colonies the native franchise (there are a few voters in Natal) is practically non-existent; in the new colunies this was inevitable under the terms of peace, May 31st, 1902. Natal has no such ground. 


\section{RESPONSIBLE GOVERNMENT IN THE DOMINIONS.}

from them by a law which will have to be reserved under the general provision that all laws imposing disabilities on natives which are not also imposed on Europeans must be reserved, and can therefore only come into force on the approval of the Home Government.

The control over legislation affecting natives thus placed in the hands of the Imperial Government is admittedly inadequate for the preservation of native rights. The solution of the question of the fair treatment of natives has been carried forward a step in the Cape, where the franchise, thanks to the action of the Imperial Government in 18511 1853 when granting representative government, is open to natives on the same conditions as to whites, and where the local legislature has only amended the law by the Registration Act, 1887, and the Ballot and Franchise Act, 1892, in the direction of the restriction of the vote to persons of some small education, and to persons whose property qualification is based on individual tenure, not on tribal tenure. In the other colonies in South Africa, the tendency is to prefer the expedient of the appointment of a strictly limited number of members to represent natives separately, a plan which, if less liberal than the Cape scheme, and open to very grave theoretical and practical objections, has yet in its favour the case of the Maori representation in New Zealand, and would at least be preferable to the existing state of affairs in South Africa $(f)$, though it is to be hoped that the Cape vote will not be merged, as this would be a most retrograde step, and contradict Rhodes' doctrine of equality of rights in case of equality of culture.

(i) Bills affecting the prerogative in any exceptional manner are also subjects for imperial control. One of the comparatively few Canadian Bills which have not come into 
operation was that of 1868 to reduce the salary of the Governor-General, while the government were warned in 1875, when the Supreme Court Bill was being passed into law, that if it purported to abolish the prerogative power to grant special leave to appeal from the judgments of that Court to the Privy Council, it would be disallowed, and the Bill was amended accordingly.

But the general rule, despite the exceptions above mentioned, is that all local Acts will be accepted, however greatly they may deviate from the principles which guide legislation in England. This doctrine has only grown up slowly; at one time it was quite common to refuse to allow Acts because in one way or another they ran counter to the views of the home Government. The classic expression of the modern rule is perhaps to be found in the correspondence with Newfoundland over the sale of the railway to the Reid Company in 1898, when the Newfoundland government of the day parted with the greater part of the publie assets of the colony for a consideration which was certainly inadequate, and which has been regarded as such very strongly by their successors in office who re-made the arrangement $(g)$. The Secretary of State pointed out clearly and forcibly the grave disadvantages of the project, but he declined to disallow the proposed Act for confirming the transfer, and to the appeals for interference by the minority in the legislature he returned the reply that the Imperial Government could not interfere with the legislation of a self-governing colony, except where imperial interests were concerned or a definite charge of bad faith brought against the government by some party whose rights were being overridden by the legislature. In a sense this despatch no more than maintains the tradition of the attitude of the Imperial Government; in 1874 the Imperial Goverument declined to

(g) Ibid. [C. 8867], [C. 9137]; Dilke, Journ. Roy. Soc. of Arts, lvi. 345. K. 
take any action in the case of a marine telegraphs Bill passed by the Canadian Parliament, against which the AngloAmerican Telegraph Company raised objections, on the ground that the matter was one of local policy in which the legislature was entitled to decide for itself without the interference of the Imperial Government. Nevertheless, the Newfoundland case was a peculiarly strong one of the refusal of interference; the action of the government was not only of obvious disadvantage to the public interests, but it fettered the hands of the government very largely in dealing with the ordinary duties of government, and exception might have been based on this ground. The course of non-interference adopted in this case was, of couree, followed when the contract with the Harmsworth firm was ratified by the legislature in 1905, though again protests were made on behalf of the opposition.

(j) The same attitude is adopted by the Imperial Government in the not infrequent cases in which they are appealed to to interfere with laws which operate harshly on residents outside the colony. Naturally colonial legislation in many cases operates to the disadvantage of those who own property in but live outside the colony, but in all these cases the Imperial Government decline to take any action on the part of the petitioners save where real imperial interests are involved. It is, indeed, impossible to hold that if people are interested in a colony they have any right to object to its legislation in any other way than through petitions to the legislature and representations to the government.

It is worth noting, as against the view which sees nothing in the action of the Imperial Government save a desire to restrict the rights of the Dominions, that it was the Imperial Government which first pointed out the dangers of the extension of this doctrine. As mentioned above, in 1874 the two houses of the Canadian Parliament passed a Bill to 
regulate marine electric telegraphs in Canada. The AngloAmerican Telegraph Company objected to certain provisions in the Bill, but their objections were overruled by the Senate, and the Privy Council, while recommending its reservation under the royal instructions as perhaps affecting the interests and rights of British subjects not resident in Canada, declared that the Bill was in their opinion advantageous for the interests of Canada. The Secretary of State, however, decided not to take any action as regards the Bill on the ground that he could not assume the responsibility of deciding between the conflicting opinions as to the policy embodied in the measure.

What was, however, still more important was, that he said that the practice of invoking the intervention of the Imperial Government whenever Canadian legislation on local matters affected or seemed to affect the property of absent persons would reduce within very narrow limits the measure of selfgovernment conceded to the Dominion. "It is to the Dominion Government and legislature that persons concerned in the legislation of Canada on domestic subjects must have recourse, and this government cannot attempt to decide upon the details of such legislation without ineurring the risk of those complications which are consequent upon a confusion of authority." Accordingly, next year the Dominion Parliament passed a new and considerably altered Act to which the Royal Assent was given ( $h$ ).

A very modern case illustrates the same principle. In 19118 the Parliament of New South Wales passed a declaratory Bill to confirm the forfeiture of certain land liconses which were alleged to have been given corruptly by the Minister of Lands at the time of the grant. This Bill was petitioned against by certain persons interested in the lands granted,

(h) Canada Sess. Papers, 1875, No. 20; cf. Ltfroy, Legislative Poteer in Canada, p. $331, \mathbf{n}$. 
and it was represented that the Governor should reserve the Act under the section of his Instructions referring to Acts affecting the interests of non-residents, but he declined to do so on the advice of Ministers that the reservation of such an Act was not contemplated by the Instructions, and a further petition to the Crown for the disallowance of the Act met with a similar refusal, the matter being essentially one for the decision of the State Parliament.

The grounds on which disallowal takes place or reservation is directed having been discussed, reference may be made to the cases in which the Imperial Parliament supplements colonial legislation $(i)$. The chief instances are undoubtedly those in which it is desired to provide legislation which will have effect beyond the territorial limits of the Colonies. Such, for example, is the Fugitive Offenders Act, 1881, under which criminals can be arrested in colonies in which they have committed no crimes and conveyed beyond the limits of the colony either to another colony or to the United Kingdom for trial. Similar are the Extradition Acts, 1870 and 1873, which provide a like process in the case of criminals who have escaped from foreign countries. The Imperial Act is sufficient to cover the whole process of transfer from one country. to another, no matter how devious the journey may be. The disadvantages of an attempt to rely on colonial legislation may be illustrated by a small point of procedure. Under the Extradition Acts their operation may be suspended in any colony which makes provision by local legislation for the procedure necessary for the handing over of the prisoner to the officers appointed to remove him to the country in which his crime has been committed. If the Imperial Act were in force in any colony, then after the prisoner had been surrendered he could be taken back to the place of his

- (i) Cf. Tarring, Law relating to the Colonies, ed. 3, Chap. VI. ; and Piggott's collection of Imperial Statutes applicable to the Colonies. 
crime by any route through the British Empire, and his detention in the custody of his escort would throughout be legal under the Extradition Acts without any further issue of warrants or judicial steps. But where the Order in Council has been made in farour of any colony, his custody, say, in the United Kingdom en route for his destination, though not illegal, would, if questioned, have to be regularized by the issue of fresh process against him, his presence in England being treated as a fresh case of extradition. The only colony to which this condition of affairs applies is Canada, and it may be doubted whether the theoretic advantages of having a colonial enactment outweigh the possibilities of difficulties arising in practice.

Other such Acts are the Colonial Prisoners Removal Acts, 1869 and 1884 , to cover cases of the transport of prisoners from one portion of the Empire to another, and the Bankruptcy Act, 1883, sects. 118 and 168 of which provide that the bankruptcy Courts of the Colonies and the United Kingdom shall be auxiliary to one another, thus enabling colonial Courts of bankruptcy to secure the assistance of the British Courts in obtaining control over a bankrupt's property, or the Act of 1859 facilitatiug the ascertainment of law in one part of the British dominions for use in trials in another part.

A whole series of such cases is to be found in the jurisdiction couferred by the Merchant Shipping Act, 1894, on colonial Courts as to making inquiries as to shipping casualties occurring either in British ships registered in the colony wherever the casualty occurred, or in British ships near the coast of or on a voyage to the possession. Similar jurisdiction is given if the party to whom the casualty is imputed is found in the colony, or any of the crew to whom the casualty occurred are in the colony, and are competent witnesses. Further, the Merchant Shipping Act also empowers the 


\section{RESPONSIBLE GOVERNMENT IN THE DOMINIONS.}

Board of Trade, if satisfied with the examinations set up in the Colonies, to allow their certificates of competence, equipment, and so forth, to be accepted all over the Empire as equal to British certificates issued by the Board of Trade.

Perhaps more important still is the legislation, the Colonial Courts of Admiralty Act, 1890, conferring on the colonial legislatures power to confer on their High Courts the powers of Courts of Admiralty, and to delegate part of those powers to the inferior Courts of the Colonies. Such laws require either the preliminary approval of the Crown, which is conveyed by despatch as in the case of the Canadian Admiralty Court Law of 1908 , or must be reserved, or contain a suspending clause.

Again, colonial laws made for the purpose of establishing the validity of marriages contracted in the colony are valid in all parts of the Empire, if the parties were at the time of contracting the marriage competent according to the law of England to contract the marriage at the time of its performance. Since the passing of the Imperial Act of 1907 permitting the marriage of a deceased wife's sister, there can, therefore, be no doubt of the validity all over the Empire of such marriages when contracted in the Colonies. Some doubt may still remain in the case of other marriages illegal in England, but legal in the Colonies $(j)$.

Further, all Colonies are enabled by the Imperial Army Act, 1881, to provide for the discipline abroad of their forces, and the same privilege is given to colonial legislatures in respect of their naval forces under the Naval Defence Act, 1865. It is, however, possible that, at any rate in the case of Canada and Australia ( $k$ ), the power to regulate naval forces outside of territorial waters may be necessarily implied

(j) $28 \& 29$ Vict. c. 64 .

(k) Cf., on the other hand, the dictum of the Chief Justice of New South Wales in Brisbane Oyster Fishery Cn. v. Emerson, cited by Lefroy, Legislative Power in Canada, p. 327, n. 1 ; Parl. Papers [Cd. 4325], pp. 38, 47. 
from the power given to these Colonies by their Constitution to provide for defence in naval matters. It must be remembered that the Act dates from before these Constitutions, and further, that it expressly disclaims any purport of diminishing the power which may otherwise be vested in colonial legislatures. Its sole aim is to confer power, not to diminish or define it.

Or, again, the Imperial Parliament will legislate for the Colonies in auy matter of imperial concern in which uniformity is essential throughout the Empire. Such, for instance, is the Foreign Enlistment Act of 1870, which provides for the maintenance of neutrality by his Majesty's subjects during the existence of war between foreign States with which Great Britain is at peace. Another example is afforded by the Territorial Waters Jurisdiction Act, 1878, by which was reversed in effect the decision of the Court in the case of The Franconia, under which the jurisdiction of British Courts did not extend to deal with the case of a crime committed by a foreigner on board a foreign ship within territorial waters $(l)$. This Act gives the power to deal with such cases to the Courts, including the colonial Courts, but requires that the permission of the Governor of a colony should be given for any prosecution under its terms in a colony. As, however, the Act does not in any way restrict existing jurisdiction, and as the decision of the Court which decided the Franconia case does not bind the colonial Courts, the practice ever since that case seems to have been to regard the jurisdiction of the colonial Courts as extending of right to all persons within the territorial waters of the colony $(\mathrm{m})$, and not to resort to the special powers of the Act.

(l) L. R. 2 Ex. D. 63.

(iin) Unless under treaty: cf. D. C. Whilney v. St. Clair Narigation Co., 38 Can. S. C. R. 303 . 
A still more important series of cases is that relating to merchant shipping. The Imperial Acts regarding merchant shipping legislate, with the significant exception of the latest -that of 1906-fairly freely for the colonies, and allow colonial legislation within narrowly defined limits. A colonial legislature is expressly empowered to regulate vessels engaged in the coasting trade of the colony and vessels registered in the colony, in both of which cases its legislation must, it seems clear, apply beyond territorial limits $(n)$. It can also apply by Act certain provisions of the Imperial Merchant Shipping Act, 1894, to vessels trading with the colony, which would not otherwise be bound by the regulations in question. But such a legislature cannot legislate for vessels on the high seas unless they are registered in the colony, or while engaged in a coasting voyage leave territorial waters. Difficult questions as to the exercise of the power to regulate coasting trade are suggested by the fact that many vessels in, e.g., the Australian trade engage in coasting operations after coming a long sea voyage. It is contended that such vessels cannot fairly be subjected to the rules which apply to coasters proper, but this contention was abandoned by the official British delegates at the Colonial Merchant Shipping Conference of $190 \tau^{\circ}(o)$, where the full right to legislate was conceded in any case where a vessel from overseas took up at one port in the Commonwealth or New Zealand passengers or goods to be disembarked or landed at another port in the same possession. At the same time, it was pointed out that the term "coasting trade" could not conceivably be allowed to cover the trade between the Australian or New Zealand ports and the Pacific, which was desired to be ranked as coasting trade by the delegates from

(n) Cf. Commonuealth of Australia Constitution Bill (Wyman's, 1901), p. 151; Harrison Moore, Commonvealth of Australia, p. 8 ; Garran, Parl. Papers [Cd. 3023], p. 61 ; 5 C. L. R. 737 seq. ; Dicey, Law of the Constitution, p. 99, n. 1.

(o) Parl. Papers [Cd. 3567]. 
Australia. Canada is, in this respect, in complete harmony with the imperial law, as its legislation is carefully confined to the regulation of coasting or registered vessels. It should, however, be noted that a Canadian law of 1878 was not permitted to come into operation because it contravened this principle, and endeavoured to legislate for vessels which were not within the competence of the Parliament to provide for $(p)$.

In the case of merchant shipping, besides uniformity there is also the necessity of providing for legislation as to ships on the high seas, and the Imperial Act provides for this. The old Acts against the slave trade were also based on the desirability of uniformity, and they still apply to all Dominions.

The Naturalisation Act of 1870 may, in the whole, be regarded as an instance of legislation for the purpose of securing uniformity. It enacts, among other things, the admirable rule of the status of husband and wife depending on the nationality of the husband, and it sets down definitely, what already was law, that colonial naturalisation, though legitimate, extends only within the limits of the colony concerned. But for that provision, there would be doubt as to the effect of naturalisation in a colony; inasmuch as though the power of the colony to legislate does not extend beyond colonial limits, the mere fact that in a colony a man had the status of a British citizen might have been held to invest him with that status everywhere. Naturalised persons in colonies are therefore treated differently from ordinary British subjects as regards passports. The passport issued in their cases recites the fact that they are only entitled to protection abroad as a matter of courtesy and not, as in the case of ordinary British subjects, as a right flowing from

(p) Todd, Parl. Govt., p. 184. For the present state of affairs, see Parl. Papers [Cd. 4355]; cf. Canada Sess. Papers, 1876, No. 22. 
their allegiance to the Crown. Like all naturalised British subjects, they are not protected in the place of their origin, if they still, by the laws of that country, remain citizens or subjects of it, despite their having been naturalised in a foreign country.

In the case of copyright the legislation of the Imperial Parliament of 1842 and 1886 is based, partly on the desire of the Parliament to secure uniformity of treatment. of this topic throughout the Empire, and partly on the necessity of uniformity under treaty arrangements. The matter is one on which there has always been a good deal of disagreement with the Government of Canada $(q)$. In 187.2 the Dominion Parliament passed an Act to awend the law of copyright, and the Bill being reserved, the Houses asked the Imperial Government in $\mathbf{1 8 7 4}$ for an early approval of the Act, which, however, was refused on the ground that the Bill ran counter to imperial legislation on the topic, and, even if assented to, would not produce any legal result. In 18i5, however, an Imperial Act $(v)$ was passed to give effect to the terms of the Canada Copyright Bill so far as possible (s). It is, however, noteworthy that even the latest Act, that of 1886, still does biud the Colonies, including the Dominion, and a Dominiou Bill of 1889 was not allowed to come into force.

On the other hand, the effort to keep up the right of the British registered medical practitioner to practise in the Colouies on the faith of that registration, was given up in the same year. Under the Act of 1860 it was laid down that any medical man registered in England under the Act of 1858 was entitled to registration in any colony on payment

(q) Canada Sess. Papers, 1875, No. 28; Parl. Papers, H. C. 39, 1890, [C. 6425], [C. 7781], [C. 7783]; Smiles v. Belford, 1 Cart. 576; Lefroy, Legislative Power in Canada, pp. 235 seq.

(r) 38 \& 39 Vict. c. 53.

(s) See now Revised Slatutes, 1906, c. 70 ; and ef. Graves \& Co. v. Gorrie, L. R. [1903] A. C. 796 ; Canadu Sess. Papers, 1890, No. 35 ; 1892, No. 81. 
of such fees as might be required, and on proof of registration. The application of this Act to Canada was contested in the case of Ontario, where the College of Physicians and Surgeons refused registration to a practitioner on the ground that the ninety-second section of the British North America Act gave the exclusive power of legislation to the province, and the Imperial Act would only apply if there were no provincial Act at all. This contention was ruled, of course, wrong in law $(t)$, but the point at issue was, in effect, conceded in the legislation of 1886 , which establishes a system of reciprocity in such matters: the registration of a doctor in the Colonies may be recognised if those who are on the English register are recognised there. In each case a special Order in Council is made after the Cuuncil has satisfied itself that the colonial degree is adequate justification for allowing colonial practitioners to appear on the British register.

The Imperial Parliament will also legislate in cases where the Constitutions of the Colonies are concerned, and where the action desired cannot be effected satisfactorily by colonial legislation. For example, in 18.44 the Parliaments of New South Wales and Victoria passed Acts to establish responsible government which contained various provisions not altogether in keeping with the powers of legislation conferred on those Colonies in 1850 , and requiring for their full effect the repeal of the Imperial Acts relative to the management of the lands of the Colonies. These Bills were in both cases altered and confirmed by Imperial Acts $(u)$. Similarly, the Constitution of Queensland was made by Letters Patent under one Imperial Act and confirmed by express legislation by another Imperial Act $(x)$. The Constitution of the Commonwealth of Australia

(t) 1 Cart. 761 ; Lefroy, Legislative Potcer in Canada, p. 218.

(u) 18 \& 19 Vict. cc. 54 , 55.

(x) $24 \& 25$ Vict. c. 44. So also Western Australia (53 \& 54 Vict. c. 26). 
was given by an Imperial Act $(y)$, because there was no means otherwise of constituting the Commonwealth, as no individual legislature or combination of legislatures could have effected the purpose in view. The same reason explains the British North America Act (z), and the abortive Act for the federation of South Africa (a).

Or, again, the Imperial Parliament will validate doubtful Acts. The cases in point are numerous. In Canada, in 18\% 0 , the passing of the Act for the establishment of the province of Manitoba was regarded as of doubtful validity, and the validity was given by the Imperial Act of 1871, which authorised the further establishment of provinces and the making of provision for their inclusion in the representation of the Dominion. In $187 \tilde{0}$ a further Act defined the power of the Dominion Parliament to set forth its own privileges by explaining the meaning of the British North America Act, s. 18 , to be that the privileges should never exceed those held by the Commons of England at the time of the passing of the defining Act, and not at the time of the passing of the original British North America Act of 1867. The same Act validated the Canadian Act of 1868, which had been held to be invalid under the old interpretation of sect. 18. Again, in 1886, the Imperial Parliament legislated to remove doubts as to the power of the Dominion Parliament to make provision for the representation in the Parliament of those territories of the Dominion which were not yet ripe to become provinces.

In Australia the same result has arisen from the complication of the rules for the reservation of Bills affecting the Constitution and the alteration thereof. In 1862 a large

(y) $63 \& 64$ Vict. c. 12.

(z) $30 \& 31$ Vict. c. 3

(a) 40 \& 41 Vict. c. 47 . Cf. also 5 \& 6 Vict. c. 120 (Newfoundland); 33 \& 34 Vict. c. 66 (British Columbia); Canada Sess. Papers, 1877, No. 86, p. 16. 
number of Colonial Bills were validated by an Imperial Act, and the process was repeated, in 1865, in the Colonial Laws Validity Act. In 1901 a batch of New South Wales, Queensland and Western Australian laws was validated, and the Australian States Constitution Act, 1907, confirmed generally, without specific enumeration, all Bills bitherto duly assented to, even if legally invalid because of any flaws in their passing. In New Zealand, imperial legislation has been confined to alterations of the Imperial Act constituting the government. Such Acts were passed in 1857, 1862 and $1868(b)$.

Other cases of imperial legislation are the Colonial Boundaries Act, $1895(c)$, the Naval Prize Act, 1864. the Official Secrets Act, 1889, \&c.

(b) See Constitution and Government of New Zealand, 1896, pp. 12 seq.

(c) No colony can extend its boundarice by legislation, because its legislation must be territorial, and this Act, therefore, enables the Crown to extend boundaries with the consent of a self-governing colony, including the Commonwealth (63 \& 64 Vict. c. 12, 8. 8), but not including the Transvaal and Orange River Colon!, which were not in existeuce when the Act passed. The colonial limits include territorial wuters (see Direct United Stales Cuble Co. v. Anglo-American Telegraph Co., L. R. 2 App. Cas. 394 ; Rhodes v. Fairbrother, Nevfoundland Law Reports, 1897, pp. 321 seq.). and, in the case of Canada, includes Hudson's Bay ; Revised Statutes, 1906, c. 45, ж. 10. 


\section{CHAPTER X.}

\section{TREATY RELATIONS.}

No question of the relations of the Imperial Government and the governments of the Dominions presents more formidable difficulties than that of the relations of the governments in matters arising out of treaties. It is, indeed, probable that the difficulties can only be satisfactorily solved by alterations in the Constitution of the Empire ; in the meantime efforts are being made to arrive at a satisfactory working basis, which will maintain the unity of the Empire while permitting to the Dominions a wide range of freedom.

From the point of view of mere law, there can be no doubt that the King, on the advice of his imperial Ministers, is entitled to make any treaty he thinks fit to conclude on such terms as appear to him equitable. The only substantial doubt which has ever been expressed as regards the limits on this power relates to the cession of territory, and it has been questioned whether such cession can be made without the assent of Parliament. It has been suggested that the power may exist, but only in case of a treaty ending a war, or, perhaps, also, in the case of a treaty made to avert a war. The Privy Council had the whole matter before them in the appeal case of Walker $\nabla$. Baird in $1892(a)$. The appellant was a British naval officer who, under instructions from the Admiralty, had, in order to carry out the terms of a modus vivendi made with France regarding the rights of fishery of

(a) L. R. [1892] A. C. 491 ; cf. In re Californian Fig Syrup Co.'s Trade Mark, L. R. 40 Ch. D. 620. 
French subjects in Newfoundland, forcibly interfered with Mr. Baird's lobster factory. Sued for damages, when the case came before the Newfoundland Supreme Court, he set up as his defence that the act was one of State, and not such as could be enquired into in any Court. The Newfoundland Court held the defence bad, and the Privy Council upheld the decision on appeal. They expressly did not deal with the result, if the defence set up had rested, not on the alleged incompetence of the Court to try the case, but on the effect of the treaty. They mentioned that the question was an important one, on which they must be regarded as expressing no opinion. The best view appears, however, to be as contended by Mr. Gladstone (b), in the discussions in Parliament in the case of the cession of Heligoland to Germany by the treaty of 1890 , that the right of the Crown to make such a cession is absolute, and that the consent of Parliament is not legally necessary, and, in point of fact, a great many instances can be found prior to 1890 of the actual cession of territory without confirmation hy Parliament. There are, however, such obvious constitutional advantages in making such cessions subject to Parliamentary consent, that the precedent of Heligoland had been followed in the case of the small cessions to France in the Convention of 1904, and the same practice will probably be followed in any case of the same kind in future.

But if the power of the Crown is in law absolute to make what treaties it will, there remain serious difficulties in the carrying out of these treaties unless Parliament intervenes. There is no absolutely decisive case $(c)$ on record as to the

(b) Hansard, ccexlvii. 764 ; cf. Anson, Law of the Constilusion, II. 297 seq. ; Danodhar Gordhan v. Deoram Kangi, L. R. 1 App. Cas. 152 ; Parlement Belge, L. R. 4 P. D. 154; Forsyth, Cases and Opinions on Constitutional Lave, pp. 182-186; my State Succession, p. 30 ; Cook v. Sprigg, L. K. [1S99] A. C. 572 ; Harrison Moore, Commonucealth of Alustralia, p. 261.

(c) Treaties are held, in British Columbia, to override laws; cf. $R$. v. "Wing 
effect of a treaty on the ordinary legal rights of a citizen. But it is almost certain that the authority of a treaty is insufficient to deprive a British subject of any right he possesses under the law of the land, unless at the same time it deprives him of his British nationality, as in a case of cession. For, in the first place, the case of Walker v. Baird has decided that the defence of act of State cannot be pleaded against him; and though their Lordships, in the judgment in question, did not decide that the orders of the Admiralty, given in accordance with the modus vivendi, were not sufficient to relieve Captain Walker from liability, it is a significant fact that the case was actually compromised by the payment to Mr. Baird of the damages awarded him and of his costs by the Imperial Government. The Imperial Parliament has, therefore, the power to render of no effect the acceptance by the Crown of a treaty entered into by His Majesty. Such a contingency is not, of course, probable; if it occurred the foreign power would have just cause for complaint or reprisals, but though the country would be bound, performance of the treaty would become impossible.

The case with a treaty expressed to bind a colony is somewhat different. It has, indeed, been argued, mainly on the strength of a somewhat ill-worded passage in a despatch $(d)$ from Lord Kimberley to the Australian Colonies in 1872 on the subject of inter-colonial preference, that the undoubted constitutional power of the Crown to bind all its Dominions by treaties is subject in the case of the Colonies, as in that of

Chong, 2 B. C. (Irving) at pp. 161, 162 (1885); Lefroy, Legislative Power in Cunada, pp. 255 seq. ; cf. dicta to the contrary in Tsewu v. Registrar of Deeds (1905), Transvaal S. C. R. 30 ; and ef. (1904) ibid. 241; Chia Gee v. Mastin, 3 C. L. R. at p. 653 ; Colonial Govt. v. Laborde, 1902, Mauritius Supveme Court Decisions, 67 seq.

(d) Parl. Papers [C. 576], pp. 6-10; already corrected in 1895 (Canada Sess. Papers, 1895, No. 49). Cf. Dicey, Law of the Constitution, p. 115 ; Todd, Parl. Gort., p. 275 ; Quick and Garran, Annotated Constitution of Commonwealth, p. 770 . 
the mother-country, to the discretion of the colonial parliaments to pass the necessary legislation to give legal effect to the provisions of the Convention. But that position cannot seriously be defended. The responsibility for the execution of treaties rests with the power which makes them-in all cases, in the last resort, the Crown, on the advice of the Imperial Cabinet-and the Imperial Cabinet is not at the end of its resources when it has made an unsuccessful effort to induce the Colonies affected to legislate. There remains the possibility of passing an Imperial Aet, and in fact the passing of such an Act has been contemplated. In view of the refusal of the Parliament of Newfoundland, in 1891, to pass legislation giving effect to the modus vivendi with France, a Bill to give effect to the modus was introduced into the Imperial Parliament, and was only withdrawn when assurances had been obtained from the delegates sent by the colonial government to confer with his Majesty's Government that the colonial parliament would enact the required legislation. Similarly, in 1907, in view of the refusal of the Newfoundland Government to take the necessary steps to give effect to a modus vivendi with the United States, an Imperial Order in Council was passed under the old Imperial Act of 1819, which prevented the operation of the colonial law as regards the boarding of American vessels.

The Crown has, therefore, full power to make any treaty and to carry it out, provided that the government can obtrin the concurrence of the Imperial Parliament. But legal power is one thing and constitutional practice another, and the action of the government as regards binding the Dominions by treaties is now guided by the two following principles. In the first place, as far as possible, no treaty is made binding on any Dominion except with the formal assent of that Dominion; in the second place, his Majesty's Government are always ready to negotiate, with the help of the Dominion

K. 
Governments, special treaties for the Dominions, thus rendering the full support of the Empire to the desires of the several parts of it $(e)$.

Naturally, the growth of these principles has been very gradual. In the great majority of treaties concluded before $1875^{\circ}$ the Colonies were included more or less as a matter of course. For example, the commercial treaty with Austria-Hungary, and the treaties with Sweden and Norway and Portugal, by which are regulated the present commercial relatious between these countries and the British Dominions, are expressed to cover all the Colonies $(f)$. It was in Australia that opposition to this practice first manifested itself in connection with the desire of the six states to enter into some form of commercial and customs union. In the existing circumstances the Colonies found themselves compelled to admit to the benefit of any reduced duties all countries possessing treaties with clauses according most-favoured-nation treatment as well as Great Britain and all the Colonies, and even after the concession in 1873 by an Imperial Act of the power to give inter-colonial preference, subject to the obligation of existing treaties $(g)$, it was felt that the practice of concluding treaties without reference to colonial wishes was improper. The view found favour at Downing-street, aud when the Secretary of State for Foreign Affairs consulted Lord Carnarvon in 1877 as to the propriety of including the Colonie. in the scope of the new treaties which it was proposed to negotiate with France and Italy, the latter replied that the Colonies should be consulted, and he accordingly sent to the colonial govern-

(e) Journ. Royal Soc. of Arts, lvi. 340.

(f) It is in each case a mere question of interpretation as to whether a general treaty covers Colonies. There is no absolute rule, as Todd, Parl. Govt., p. 265 , suggests.

(g) See Parl. Papers [C. 576] and [C. 703], and the Act 36 Vict. c. 22, which permits preference to the several Colonies in Australasia, but forbids differentiation against the different foreigu cuuntries; see p. 192. 
ments for concurrence a draft clause to be inserted in future commercial treaties providing that the treaty should not apply to the self-governing Colonies unless they adhered within a certain period $(h)$. The colonial governments naturally welcomed the concession, and the form of clause, slightly modified, has been adopted in all commercial treaties of recent date, which the negotiating powers were willing to extend to the Colonies. Since 1899, however, a further modification has been made in the colonial interest. Not only are such treaties not to become binding without a speoial adherence on the part of the colony, but also the colony is to be able to withdraw by giving twelve months' notice without prejudice to the binding effect of the rest of the agreement. The first one was that of the Convention of 1899 with Uruguay, where six months' notice is prescribed, and clauses to this effect have, by special conventions, been introduced into the Greek treaty of 1886, the Egyptian treaty of 1889 , the Paraguayan treaty of 1884 , and the Liberian treaty of 1848 , while the new treaties of 19115-7 with Nicaragua, Servia, Roumania, and Bulgaria contain similar provisions. At the same time, it is in each case stipulated that, even if a colony does not choose to enter the treaty, she will retain most-favoured-nation treatment so long as she continues to afford most-favoured-nation treatment to the foreign Power $(i)$.

It is, however, important to notice that the power of adherence and withdrawal is not conferred technically on the colony concerned. The adherence or the withdrawal are purely matters for the Imperial Government; it is not even hinted that the Imperial Government will consult or obtain the consent of the colony to its adherence or withdrawal

(h) Todd, Parl. Gort., p. 266 ; New Zealand Parl. Papcrs, 1878, A. 2.

(z) See the cullection of Trealies relating to Commerce and Narigation, published in 1908 . The treaties referred to are all included in the Trealy Serien, issued by the Forcign Office; see, e.g., [Cd. 3858], p. 12, for the exact form of clause in the Bulgaria treaty. 
being notified. Both in fact and in law the responsibility of adhering or withdrawing rests, as it must rest, with the Imperial Government as the representative in external affairs of the Empire, but by a well-established constitutional practice each Dominion is duly consulted, and its wishes in these matters respected. From the same doctrine of the necessary responsibility of the Imperial Government for foreign affairs in the last resort, follows the restriction of these treaties, in which the Dominions are not necessarily included, to cases where purely political issues are not involved. It would obviously be absurd for the British Empire to attempt to conclude a treaty of alliance with any foreign Power and yet to reserve the right of the Colonies not to be bound by the terms of the alliance. Similarly, the Empire must in arbitration treaties act as a whole $(k)$, and among other obvious examples of the same principle are treaties relating to the conduct of hostilities, political guarantees, and extrarlition treaties. In the latter case there are also paramount grounds of convenience for the rule. It is already hard enough to secure the condemnation of fugitive criminals; it would be intolerably hard if there was a different rule of law for the mother-country and her various possessions. There are therefore no colonial option clauses in any of the Hague Conventions of 1899 and 1907, in the Japanese alliance of 1905 , in the general treaty with France of 1904, in the treaties with Spain and France for the maintenance of the status quo in the Mediterranean, or in the treaties with France, Germany, Denmark, Holland and Sweden for the preservation of the territorial possessions of the signa-

(k) But in the latest treaty, that with the United States of 1908, the British Government have reserved the right to obtain the concurrence of the Dominion concerned before arbitrating a question concerning any Dominion. But they do not bind themselves to obtain the consent. The concession has been warmly received by Canada and Newfoundland. See Treaty Series, No. 21 of 1908. 
tory Powers on the North Sea, nor in any of the numerous extradition treaties of the Empire. On the other hand, the treaties in which the option occurs cover a very wide ground; they include every conceivable commercial and shipping question as a matter of course, but they also include immigration, the right to hold lands and carry on business, besides important if minor provisions, such as those relative to exemption from military service and so forth. It is clear that in questions of the latter class some difficulty may arise. It may, for example, be asked whether, in the event of Australia not adhering to the recent treaty with Bulgaria, an Australian British subject is to be entitled to the benefits of the treaty other than commercial in the widest sense of the word. The answer would appear to be in the affirmative, but if not there would arise a problem of great difficulty-what meaning is to be attached to the conception of an Australian British subject? Whether birth or domicile be chosen as the criterion, the position would be awkward, and the fact points to the necessity of careful discrimination in treaty-making in the future between provisions in effect political and commercial matters in which alone the principle of locality which affords the justification for differential treatment applies.

But not only are the Dominions consulted before they join the treaties entered into by Great Britain : every effort is made to secure the passing of treaties desired for any special reason by the Colonies. The agitation for power to conclude special agreements with foreign countries was originally put forward by the Australasian Colonies in an unacceptable form in 1871 , when it was apparently contemplated by New Zealand that direct negotiation with foreign Powers should take place $(l)$. The Imperial Government naturally declined

(l) Suggested also in a debate in the Canadian House of Commons in 1870 (March 21st), but negatived. The only treaties not concluded directly by the Inperial Government are those which Cansda can negotiate with 
to part with any of their control over foreign relations, and would only concede to the Australian Colonies the same right as had been accorded before federation to the Canadian Colonies-that of making among themselves preferential arrangements. But in 1871, in the case of the negotiation of the Treaty of Washington with the United States, the Canadian Prime Minister, Sir John Macdonald, was appointed one of the British High Commissioners and Plenipotentiaries $(m)$. In his papers the Prime Minister complained a good deal of the readiness of his colleagues to surrender Canadian interests for the sake of peace with the United States, but his government was ultimately advised by him to accept the treaty, and it must be remembered that the anxiety of the British Commissioners to secure an agreement was largely due to the fact that in the case of hostilities the Dominion would be exposed to the brunt of the American attack, when her population and resources were inadequate for such a struggle, and that they surrendered quite as readily as they did Canadian interests the interests of Great Britain as regards the Alabama claims. The same precedent was followed in 1874 when Senator Brown was appointed, along with the British Minister at Washington, a plenipotentiary for the negotiation of a reciprocity treaty with the United States. Such a convention was actually signed, but though the British Government were prepared to ratify, the United States allowed the treaty to drop (n). In 1879 Sir A. Galt similarly was employed in negotiations with France and Spain for commercial arrangements with Canada,

Indian tribes, who are British subjects (compare the powers in this regard of the Viceroy of India), and the powers of the High Commissioner for South Africa, e.g. sect. 3 of the Commission to Lord Selborne of 1905.

(m) Canada, Sess. Papers, 1872, No. 18. An earlier precedent of 1865, in connection with reciprocity negotiations with the United States, is noted, ibid. $1867-8$, No. 63 ; 1869 , No. 59 ; and see ibid. 1882 , No. 73 ; 1883 , No. 89.

(n) House of Commons Paper's, 1874, lxxv. 931-956. 
and Canadian Commissioners were concerned in the negotiation of the Chamberlain-Bayard Treaty of 1887 regarding the North American fisheries which the Senate refused to ratify (o). In $1893 \mathrm{Sir}$ Charles 'Tupper negotiated and signed, with the Ambassador at Paris, a commercial treaty between Great Britain and France respecting Canadian trade, and in 1907 Mr. Fielding and Mr. Brodeur, the Canadian Ministers of Commerce and Marine, negotiated and signed, along with the Ambassador at Paris, a much more comprehensive commercial treaty $(p)$. Similarly, in 1890 the Premier of Newfoundland was permitted to negotiate a treaty with the United States regarding the trade of his colony, but that treaty was not ratified by the British Government because of the protest of Canada that the effect of the conclusion of the treaty would be to hamper her in her pending negotiations with the United States for reciprocity $(q)$. When, however, in 1902 a similar treaty was negotiated between Sir Robert Bond and Mr. Hay the British Government no longer refused to ratify, holding that it would not be fair further to prejudice the claims of Newfoundland in favour of Canada, a signal recognition of the growing independence of the Colonies in fiscal matters, not merely as regards the mothercountry but also as among themselves. The American Senate, however, refused to ratify the treaty, which accordingly has never taken effect $(r)$.

It has recently been claimed that the recognition of the right of the Colonies to have treaties negotiated for them has been extended in a marked degree. This contention, which was discussed at great length by the Canadian Parlia-

(o) Farl. Papers [C. 5262].

(p) Ibid. [C. 6968], [C. 7928], [Cd. 3823]; Canads Sess. Papers, Nos. 10^ and 10B. Cf. p. 204.

(q) Parl. Papers [C. 6303].

(r) Ibid. [Cd. 3262]. 
ment on the 14th to 16 th January, 1908, in connection with the Anglo-French Convention of 1907 regarding Canadian trade, rests upon the fact that the actual negotiations with the French Government, which led to the settlement of the terms of the treaty, were entrusted entirely to the Canadian negotiators, whereas in the case of the treaty negotiated by Sir Charles Tupper in 1893, the British commercial attaché at Paris was associated with Sir Charles in the negotiation. The point is not without significance, but its importance can easily be exaggerated. Sir Charles Tupper claimed in 1893 the sole negotiation of the treaty, and his claim was doubtless just. The attaché, Sir J. Crewe, a man of great experience, no doubt afforded him assistance, but in substance the negotiation must have lain in the hands of the Minister who alone could say with responsibility how far the Canadian Parliament would go in ooncessions to France. It would have been very absurd to ask the Canadian Ministers to be associated formally in the negotiations with an attache who could know practically nothing about the matter compared with the Ministers, and, in point of fact, the Ministers had at their disposal any help which the Embassy could afford. All substantial control over the negotiations was secured to the British Government, in that the full powers to conclude the treaty were conferred on the Ministers, and they signed the treaty jointly with the Ambassador (who needed no special power), and the terms of the treaty received the approval of the British Government before they came-into the form of a treaty, while after signature the treaty required not merely the assent of the Canadian Parliament, but also ratification by his Majesty's Government. Similar remarks apply to the treaties as to boundary delimitations, fisheries in boundary waters, conveyance of prisoners, and wrecking, concluded in 1908 for Canada with the United States $(s)$.

(s) Treaty Series, 1908, Nos. 17, 18. These were only signed by Mr. Bryce. 
Naturally the British Government must impose certain restrictions upon the extent to which any Dominion can have a separate treaty negotiated for it. In commercial matters, the rule was laid down by Lord Ripon in his circular $(t)$ to the Colonies in 1895 , that any preference in commercial matters given by a colony, whether to another colony or foreign Power, must be shared by Great Britain, while any concession granted to a foreign Power must be granted to all the British Dominions $(u)$. 'The equity of this rule is obvious, and it has readily been adopted by the Canadian Government in the Act confirming the AngloFrench Convention of 1907 , in which it is enacted that all the privileges accorded to France shall apply to all the British Dominions so long as they shall continue to be enjoyed by France $(x)$. Further, no colony would, it may be assumed, be allowed to negotiate a treaty in opposition to any substantial interests of the other Colonies, but probably every government will be disposed not to insist too strongly on this doctrine, inasmuch, as a rule, the gain to the contracting colony will be much more certain than the loss to the other Colonies.

In consequence of the former practice of concluding treaties without consulting colonial governments, it has been found necessary to take steps to relieve governments from the obligations imposed upon them. The most striking example of this occurred in 1897 , when it was discovered that the existence of most-favoured-nation clauses in the treaties of 1862 with Belgium and of 1865 with the North German Federation, applied to other German States by further agreements, rendered to a great extent nugatory the

(t) Parl. Papers [C. 7824], p. 16 ; see Canada Sess. Papers, 1908, No. 10в, p. 7. Cf. also Purl. Papers [C. 5091], [Cd. 3523].

(u) Cf. undertakings given by Canada in 1893-9.5 (Canada Sess. Papers, 895 , No. 49), before the treaty was ratified.

(x) Cf. Canada Sess. Papers, 1908, No. 10. 
desire of the Canadian Government to extend preferential treatment in fiscal matters to Great Britain. These treaties were accordingly denounced in the interests of the Empire $(y)$, thus removing all the impediments to the grant of preferential treatment by a colony to the mother-country. Nevertheless, despite the importance attached to this principle, the British Government were prepared to ratify the Hay-Bond Newfoundland Convention, under which, on certain specified articles, absolute equality of treatment with the United Kingdom and the Colonies is given to the United States, perhaps the most striking instance on record of the unwillingness of the British Government to curtail the freedom in matters of fiscal arrangements of the Colonies (z).

Under the modern system of consulting the Dominions as to the acceptance of treaties, the natural mode of giving effect to their provisions would be where legislation was necessary by local legislation, and this is the ordinary practice; so Canada legislated as regards the Treaty of Washington, 1871, as regards the French treaties of 1893 and 1907, and Newfoundland as regards the French treaty of 1904. In cases where even now the Dominions are not consulted imperial legislation would appear to be constitutional, and in fact alterations of the fugitive criminals' extradition agreements are given the force of law in the Colonies by virtue of the Imperial Extradition Acts. Even in this case, however, Canada has exercised the right of legislation conferred upon her by sect. 132 of the British North America Act, 186i, under which the Parliament of Canada is given all necessary power for performing the obligations of Canada arising out of treaties between the Empire and foreign Powers. The operation of the Imperial Acts is accordingly suspended by Order in Council within Canada so long as the

(y) See Parl. Papers [C. 9423], [Cd. 1630].

(z) Ibid. [Cd. 3262]. 
Dominion legislation (a) remains in force. Similarly the treaty obligations of the Colonies under the various copyright conventions are in part enforced throughout the Empire by the Imperial Acts of 1842,1847 , and 1886. Under the Merchant Shipping Act, 1894, there are saved any rights in the coasting trade of a British possession granted to a foreign country before 1869 ; the Australian Colonies and New Zealand were forbidden by Imperial Acts $(b)$ to enact any customs legislation contrary to treaty, and so forth. It still remains a standing instruction in the Royal Instructions issued to the Governors of all the Dominions save Canada, New Zealand and the Commonwealth, that they shall reserve any Bill which may conflict with treaty rights. Reservation on this ground has been very common. It will suffice to mention the Foreign Fishing Vessels Act, 1906, of Newfoundland, which was not to come into force until approved by his Majesty's Government, and which has never received such approval, and the Bill of the Australian Commonwealth of the same year conferring a preference on British goods imported in ships of British origin manned by white labour, which was reserved by the advice of the Commonwealth Ministry, on an intimation from the Secretary of State that the provision ran counter to those treaties which gave foreign shipping national treatment in the British Doninions $(e)$.

The Imperial Government thus by its power of legislation and by the use of the veto controls more or less effectively the carrying out of treaty obligations throughout the Empire.

(a) Revised Statutes, 1906, c. 155.

(b) For New Zealand, see 15 \& 16 Viet. e. 72, s. 61. In the case of the States the provision is superseded by the fact, as to customs, that the Commonwealth has plenary power, but still applies to shipping dues: 36 Vict. e. 22 .

(c) Parl. Papers [Cd. 3339]. Cf. also Mr. Deakin's recugnition of the force of treaties and the Imperial authority [Cd. 4355] : Lofroy, Legislative Poner in Canada, p. 256. 
It must also in the last resort determine the interpretation of the treaties which it concludes, as was asserted in the case of the question which came up in 1874 as to whether the terms of the Treaty of Washington bound the colony of British Columbia, which became part of the Dominion after the conclusion of the treaty $(d)$. Similarly it must rest in each case with the Imperial Government to decide in what measure it will insist on enforcing the full benefits of the treaty as it conceives them. So, in $190 \%$, the Government, while concurring in and defending against the United States the claims of Newfoundland under the treaty of 1818 regarding the American fisheries, did not refuse to conclude a modus vivendi with the United States $(e)$.

Relations so delicate and complex cannot in all probability indefinitely continue; but any alteration (such as the association of Dominion representatives in negotiating political treaties) would involve the acceptance by the Dominions of a proportionate share in the expenditure on national defence, and would probably embarrass colonial governments. For the present no such result is in sight, and the rules in force must continue. They depend for their success on the forbearance and good sense of all parties concerned, and, as Sir Wilfrid Laurier pointed out in a debate in the Canadian Parliament on the 27th February, 1908, however anomalous in theory, are in practice for the present open to no serious objection. Moreover, the Canadian Government freely corresponds with the Ambassador at Washington, and he uses his discretion in acting on their representations or referring home for instructions.

(d) Canada Sess. Papers, 1876 , No. $42 ; 1880$, No. 111 . Cf. also as to effect of entrance into a federation on treaties, correspondence regarding the Australian Navigation Bill, Parl. Papers [Cd. 3891], [Cd. 4355], and my State Succession, p. 97. The question of the application of treaties to subsequently-acquired Colonies like the Transvaal and Orange River Colony is discussed ibid., pp. 19 seq.

(e) Cf. Parl. Papers [Cd. 3262], and especially [Cd. 3765], pp. 175-179. 


\section{CHAPTER XI.}

\section{THE PREROGATIVE OF MERCY.}

Special interest attaches to the history of the exercise of the prerogative of mercy in the Colonies. For various reasons it is only very slowly that its exercise has been subjected to the same rules as those governing the exercise of the Governor's executive powers, and the process is still, in certain cases, incomplete.

The royal prerogative of pardon exists in its full extent in all Colonies, and in each case is delegated by the Royal Letters Patent and Instructions to the Governor. But, though the power is delegated, that fact has of course no effect in diminishing the right of the Crown to grant pardons directly, on the advice of the Imperial Ministry, since the delegation is a voluntary act, and cannot bind or fetter the discretion of the Crown $(a)$. There are, however, obvious reasons of convenience why the power of pardon should not be exercised, and, in point of faet, cases of the exercise of the power are almost unknown.

'The full powers of pardon which exist in Great Britain are not, however, necessarily conferred upon a colonial Governor, and, in point of fact, in no case have they been so conferred; while only gradually has the actual power of pardon been transferred from the Governor to his Ministers. It is, indeed, obvious that the considerations which render the personal action of the sovereign impossible in the United

(a) Cf. Lefroy, Legislative Power in Canada, pp. 81, n., 121, n., 131, n. ; Harrison Moore, Commonvealth of Australia, p. 220. 


\section{RESPONSIBLE GOVERNMENT IN THE DOMINIONS.}

Kingdom do not apply to the Governor, and in the early days of colonial government, before the rise of an enlightened public opinion, the Ministers would have been gravely incommoded had the grant of pardons been deemed to rest solely in their hands.

The modern practice on the matter dates from a circular despatch addressed by Lord Carnarvon to the Governors of all the Australian Colonies, on 4th May, 1875. This circular was the consequence of a long eorrespondence on the subject, which had passed between successive Governors of Victoria and New South Wales and Secretaries of State. In reply to Lord Belmore in 1869 Lord Granville, and in a circular in $18: 1$ Lord Kimberley, laid down the rule that the Governor must, in each ease, consult either his executive Council or a Minister, and decide only after hearing their advice. Nevertheless in 1872 Sir Hercules Robinson found that the practice in New South Wales was to leave the Governor to decide all cases on his personal responsibility without the aid of ministerial advice. This course proved very inconvenient, and the Governor's action in releasing the bushranger Gardiner was the object of much criticism in the colonial Parliament. The Governor discussed the whole question with his Premier, Mr. Parkes, and the latter was ready to alter the practice, and to advise the Governor, but only on the understanding that the usual rules of constitutional government were applied. the Governor accepting ministerial advice, unless he was prepared to dismiss his Ministers. Sir Hercules Robinson advised the acceptance of this arrangement, which was concurred in by the Secretary of State, and made applicable to all the Colonies in Australia. But in accepting the principle the Secretary of State did not go so far as did Mr. Parkes, but insisted that the Governor must exercise a personal discretion after taking the advice of his Ministers, especially, but not only, where any imperial 
interest was involved. $\mathrm{He}$ argued that by this means in serious cases the Ministers would be relieved from the sole responsibility of decision and from the resulting pressure from interested parties.

The exact nature of the system intended by the Secretary of State becomes rather clearer on examination of the permanent Letters Patent issued in the decade 1870-1880 for the ehief self-governing Colonies. In the accompanying Instructions the Governor is given general directions to accept the advice of Ministers unless for special reasons he thinks fit to do otherwise, and in the absence of any other provision this rule applies to cases of pardon. In the special case of death sentences, however, a difference is made; there he is directed, after receiving the advice of his executive Council, to decide on such cases according to his personal discretion. It follows, therefore, that in all cases save those of death sentences the Governor must accept ministerial advice, unless either imperial interests are concerned or he is prepared to find other Ministers; but in the case of death sentences he must exercise his personal discretion, and cannot relieve himself of responsibility by relying on ministerial advice (b).

This state of affairs, modified merely in each colony by the amount of interference in such matters desired by the government for the time being, prevailed in the Australian Colonies up to $1892(c)$, and is still the rule in Newfoundland, the Cape of Good Hope, and Natal, while the Royal Instructions to the new Colonies of the Transvaal and the Orange River Colony contain identical provisions. In all these cases the reasons for the maintenance of the rule are obvious : the Colonies in question are in point of population small,

(b) See House of Commons Papers, 1875, liii. 630 seg. ; Todd, Parl. Gort., pp. 344-369; Queensland Assembly Votes and Proceeding, 18s?, i. C01.

(c) For the eauses of the change, the case of the Maori Mahi Kui, of. New Zealind Parl. Papers, 1891, Sess. 2, A. 1 : 1892, A. 8. 
and, in the case of the four last, are peopled by large numbers of natives, with the result that in cases of murder it is not desirable that there should be even the possibility of political feeling arising by the decision resting with a political party. The same rules were in force in Canada prior to federation, and, after federation, up to the time of the appointment of the Marquess of Lorne as Governor-General ; and so for instance in 1861 the Governor-General reprieved a prisoner against the advice of his executive Council, while in 1877 the Governor-General referred home for the consideration of the Imperial Government the case of Peter Martin, it being, of course, perfectly permissible for the Governor-General to require assistance on any duty entrusted to him by the Secretary of State. In 1876, however, the Canadian Minister of Justice, Mr. Blake, raised objections $(d)$ to several of the provisions in the Royal Instructions to the Governor-General of Canada, which were, he argued, out of place under the advanced stage of responsible government existing in Canada, and, after consultation with the Imperial Government, the latter readily revised the Instructions and issued a new set to Lord Lorne. As regards the question of pardon, the new Instructions required the Governor-General, in the exercise of the power of pardon, to consult in minor cases one Minister and in other cases the executive Council, and in any case in which a pardon or reprieve might affect the interests of the Empire or of any country or place beyond the jurisdiction of the Dominion Government, he was to take these interests into his personal cousideration in conjunction with the advice tendered to him, this clearly showing that in all other cases he was to act on ministerial advice, unless, of course, in any case he was prepared to find new Ministers if his government resigned as the result of a refusal to accept their advice.

(d) Canada Sess. Papers, 1879, No. 181; cf. Parl. Papers [C. 5091], pp. $545 \mathrm{seq}$. 
The new form of Instruction was introduced after consultation into the Australian Colonies in July, 1892, while it was first inserted in the permanent Instructions issued in New Zealand in April, $1892(e)$. Naturally the model of the Canadian Instructions was followed in drafting the Royal Instructions for the Commonwealth of Australia, and pardons are to be given on ministerial advice save in the case where imperial interests are directly involved.

As a matter of fact, the actual share in the administration of the prerogative varies a good deal in each individual ease. The case of Shortis $(f)$ is one where a pardon was given by the Governor-General, after consulting the Secretary of State, the Council not advising, and we have the assurance of the Canadian Minister of Justice, given in Parliament in 1908, that the Governor-General examines carefully the recommendations submitted to him and discusses exceptional cases with his ministers : until quite recently the Governor of Newfoundland practically exercised the power on his own authority, and on the one or two occasions in Australia where in the past attempts have been made to treat the matter as solely an affair for ministerial decision, protest has always been made with satisfactory results, it being recognised that the Governor must in every case consider whether there is any imperial interest directly involved. Clearly the matter is one in which a Governor who has the confidence of his Ministers can be consulted with much advantage to the publie interests, as he can be relied upon to eonsider the question without regard to local feeling or interests.

There remain to be noticed various minor matters in which the Instructions to Governors have been modified as regards the prerogative of mercy. The case of the pardon

(e) Constitution and Government of New Zealand, 1896, pp. 187, 209, 210.

(f) Canada House of Commons Debates, 1896, Sess. 2, p. 2279; 1908, pp. 2915 seq. ; 33 Can. Law Journ. 53.

K. 
granted by the Governor of New South Wales to the bushranger Gardiner in 1872, on condition that he should leave the colony, elicited a protest from the United States, and the Secretary of State pointed out the grave objections which existed to the grant of pardons to such criminals conditional on their carrying their criminal propensities to other countries. In consequence the Instructions to the Governor of South Australia issued in 1877, and those to the Governor-General of Canada issued in 1878 , followed by all subsequent Instructions down to 1906 , contained clauses forbidding the grant of pardons on condition of absence from the colony, except only in cases of political offences not accompanied by other grave crime. This exception was adopted on the suggestion of Mr. Blake, who pointed out that in the case of political offences banishment was often the only way of securing tranquillity without keeping the offender constantly in prison. In 1906, however, it was proposed by the government of the Cape that the Governor should be authorized to grant pardons conditional on the departure from the country of criminal aliens or British subjects not domiciled in South Africa. It was then felt that it was impossible to maintain in full force the doctrine that international comity forbade the granting of pardons in such cases, in view of the fact that not only was expulsion of criminals a favourite mode of procedure with foreign governments, but also the Imperial Parliament had in the Aliens Act of 1904 recognized banishment as a punishment for foreign criminals. Accordingly the Letters Patent were altered so as to permit the banishment of aliens, but not of British subjects, the Imperial Aliens Act having no application to British subjects. Similar provisions were subsequently inserted in the Royal Instructions issued to the Governors of the Transvaal and the Orange River Colony. It must in this connection be remembered that circumstances in South Africa are peculiar, and that there is an unusually 
large number of professional criminals settled there. No such provision appears in the new Letters Patent of 1907 for New Zealand.

Since 1878 also, acting on a suggestion of Mr. Blake, explicit authority has been given to Governors to grant pardons to accomplices who have committed offences for which they might be tried in the colony, though the offence was not actually committed in the colony. It has also been held, in a case arising in the Bahamas, that a Governor has power to remit a sentence imposed for contempt of Court (g), a power the existence of which in the United Kingdom has been doubted, in the case of committals for contempt of Irish Courts in land matters, apparently without cause. The powers of the Governor extend also to the grant of pardons to men or officers sentenced by courts martial $(h)$ in the Colonies, even in the case of imperial troops over whom the Governor, as such, has no direct control; but it is not usual for the Governor to use his powers in this respect, such sentences being left to the discretion of the War Department on the advice of the Judge Adrocate-General (i).

Difficulties as to the power of pardon arise in those cases where pecuniary penalties are involved of which the whole or some part is payable to the informer. In the United Kingdom the power to remit such penalties in whole is given by an Imperial Act $(k)$, but the Act is not expressed to extend to the Colonies, and the extent to which the power can be exercised in the Colonies, which was recently discussed

(g) In re Bahama Islands, L. R. [1893] A. C. 138; Hansard, 1908, cxciii. 102.

(h) Cf. also his statutory duties, Army Act, 1881, s. 54 .

(i) Governors are not entitled to pardon before conviction principal offenders (Harrison Moore, Commonuealth of Australia, p. 219), and in the Commonwealth the powers of the Governor-General and Governors relate to offences against federal and State laws respectively, ibid. p. 289.

(k) 22 Vict. c. 32 . 


\section{RESPONSIBLE GOVERNMENT IN THE DOMINIONS.}

in the Newfoundland press $(l)$, is in each case a matter of local law. But such remissions are not a part of the exercise. of the prerogative, as they are made under statutory sanction by the Governor, not under the special delegation of the Royal power $(m)$.

(l) Evening Telegram, Jan. 20th, 1908.

(m) Similarly, as pointed out above, p. 140, Canadian LieutenantGovernors have a limited statutory prerogative, see Ontario Act, 51 Vict. c. 5 : 23 Can. S. C. R. 468, and contrast Canada Sess. Papers, 1877, No. 89, p. 333 . 


\section{CHAPTER XII.}

\section{HONOURS.}

The power to grant titular distinctions is not one of those which, as a matter of course, are delegated by the Crown to a colonial Governor (a). A Governor is not a Viceroy, and the powers which will be implied in his commission are only those which are essentially presumed by their necessity to enable him to administer satisfactorily the government of the country, and it is imposeible to assume that the right to grant honours is one of these powers. Moreover, the value of a decoration is in the main based on the fact that it is more than a mere governmental grant; it is esteemed as a mark of the personal favour of the Sovereign, and its value is certainly increased by the notorious fact that no Sovereign has ever felt bound, or has been expected, to accept all the recommendations made by Ministers. Further, if decorations were merely local in origin, they would lose all the value now attaching to them as signs of rewards for services to the Empire. While, therefore, there would be notbing illegal (b) in a colonial legislature enacting that there should be a colonial order of knighthood, to which appointments could be made by the Governor-General, the Bill could not be assented to by any Governor without sanetion from the

(a) Cf. Lefroy, Legislative Power in Canada, pp. 87-89.

(b) This statement may be doubted, but I cannot believe that the power to legislate for the peace, order and good government of a colony excludes any conceivable topic from the lezislative power of the colony, except, indeed, the destruction of that status itself. See Chap. VI. 
Imperial Government, which would certainly not readily be given for the reasons indicated above. Nor does it appear that any such legislation would be desired by the Colonies themselves.

The same remark applies to the precedence assigned to officials and others in the Colonies. This is granted usually and properly by despatches signifying the King's pleasure in each case ; sometimes by charters of justice (as in the case of judicial officers), or by Letters Patent. Clearly such lists can only be drawn up in conjunction with the government of the colony concerned, who alone know local circumstances, but the decision is equally obviously one which cannot rest merely on the wishes of the local government. Attempts have, however, been made to argue that such matters are solely for the determination of the colonial government; in 1872 the legislature of South Australia passed a Bill (c) to regulate precedence in the colony, by which all precedence to colonial bishops was removed. The Act was reserved by the Governor, and the assent of the Crown was refused by the Imperial Government, on the ground that the matter was one for the decision of the Crown and not for the Parliament, though any desires expressed by the Parliament would receive the most attentive consideration, and would be given effect to as far as possible. The House of Assembly then passed an address to her Majesty expressing their dislike to the grant of precedence to ecclesiastical persons, and in reply the Imperial Government gave an assurance that no prelate of whatever denomination would in future be granted precedence in the colony, though the existing precedence enjoyed by the bishops of the English and Roman Churches would not be revoked, unless the incumbents of those offices were ready to agree. A similar

(c) South Australia Parl. Papers, 1872, Nos. 61 and 68 ; Journals, pp. 194, 230 . 
question arose out of a decision by the Secretary of State in 1877, that ex-judges should be given, in the Colonies in which they have served, precedence for the remainder of their lives immediately after the actual holders of judicial office. Sir George Grey, in New Zealand ( $d$ ), gave expression to a most intemperate protest against this decision of the Secretary of State, and insisted, with much vehemence, that the control of precedence was just as much a matter of colonial competence as anything else. The Secretary of State declined to adopt this view, and, indeed, it is quite inconsistent with the doctrine that in these questions the Sovereign is entitled to exercise his own discretion. The extent to which this principle is still maintained is illustrated by the fact that the Table of Precedence for the Commonwealth of Australia, though, of course, drawn up in consultation with the Gommonwealth Government, was promulgated by the royal authority alone, and rests only on the royal approval, having no statutory force. Further, the latest edition of the Colonial Regulations $(e)$ contains the provision that persons enjoying precedence by right of birth in the United Kingdom cannot lose such precedence when resident either temporarily or permanently in a colony, a direction which clearly rests on the royal authority alone.

The Colonial Regulations ( $f)$ also assign to members of the Royal Family in a colony precedence immediately after the Governor himself. There has, however, grown up of late the practice of making the Heir Apparent, if visiting a colony, take precedence even of the Governor. This was the case in Australia and Canada on the occasion of the Duke of York's tour in 1901, when, however, the Governor of Now Zealand was given precedence over the Duke, according to

(d) New Zealand Parl. Papers, 1878, A. 1.

(e) No. 142 (ed. 1908).

(f) Ibid. 
the older rule. Similarly, when visiting Canada for the Quebec tercentenary celebrations in 1908, the Prince of Wales took precedence even of the Governor-General of Canada $(g)$. The practice is somewhat anomalous in view of the fact that the Governor-General is technically the representative of the King himself, but it has the advantage of bringing into prominence the exceptional honour conferred on the Dominion by royal visits. In the case of minor members of the Royal Family, no doubt the older practice will continue to be followed.

As regards the bestowal of honours the principle has occasionally been asserted that all recommendations must emanate from the colonial government. The disadvantages of such a course were early pointed out by the Earl of Elgin (h), who insisted on the superior value of honours bestowed without suspicion of party influence, and despite various protests by colonial governments, notably one by Sir George Grey in $1879(i)$, the rule is still maintained that honours are not mere party rewards. To a certain extent the usage appears to have grown up that rewards for purely political services will not be given save with the consent of the government for the time being in office, but this usage-for it does not seem to be any more-has no application to. honours for purposes other than political in the spheres of philanthropy, literature or art.

One old controversy has happily been settled after much discussion, the right of the Governor-General and the Lieutenant-Governors of the Canadian provinces to create King's Counsel. The dispute, which occupied a prodigious amount of the time of the Courts of Canada, turned on various

(g) In his tour in Canada in 1860, his Majesty, when Prince of Wales, had no such precedence.

(h) Walrond, Letters of Lord Elgin, p. 114.

(i) New Zealand Parl. Papers, 1879, A. 9. 
points, such as the delegation of the royal power implied in the Letters Patent of the Governor-General and the extent to which the Lieutenant-Governors still, despite the fact that they were appointed by the government of Canada, represented the King. It is quite impossible to regard as altogether satisfactory the results of the decisions of the Courts on the subject: "what is really clear is, that neither the GovernorGeneral nor the Lieutenant-Governors had any right whatever to confer the dignity of King's Counsel, if the conferment was the giving of an honorary distinction; since neither the one nor the others had any delegation of the royal prerogative of the bestowal of honours $(k)$. As a matter of fact, the granting of the position of King's Counsel must be deemed to be the granting of an official position, and accordingly to fall under the power, given to the Governor-General and the Lieutenant-Goveruors alike $(l)$, of appointing all necessary officers in the Dominion and the provinces respectively. This view was that which prevailed in the other Colonies, and the position has freely been bestowed by local governments upon their supporters at the Bar. It is of course open for the rank of King's Counsel to be conferred even upon colonial barristers of mark by the Imperial Government, but such cases are rare in the extreme and practically never conferred unless the recipient has had occasion to render services, properly speaking, imperial, beyond the limits of the colony itself.

It would hardly be worth while to trace in detail the progress of the struggle which ended in the settlement of the matter. The law officers of the Crown in England advised,

(k) Att.-Gen. for Dominion of Canada v. Att.-Gen. for Province of Ontario, L.' R. [1898] A. C. 247; Lefroy, Legislative Poucer in Canada, pp. $133 \mathrm{seg}$.

(l) Cf. Lefroy, pp. 88, 123-176. The moustrous doctrine that the King forms no part of the executive of the provinces, now exploded, cansed hopeless confusion. 
in 1872, that the Governor-General alone had the right, without legislation, to appoint Queen's Counsel and to assign them precedence, but that it was open to the provincial legislatures to pass laws empowering the Lieutenant-Governors to appoint provincial Queen's Counsel, and to regulate the right of pre-audience in the provincial Courts as between these officers and Queen's Counsel appointed by the GovernorGeneral. Advantage was taken of this opinion by the provincial legisiatures to provide for the appointment of provincial Queen's Counsel, and it was out of the legislation passed by the Parliament of Nova Scotia that the trouble arose. Mr. Ritchie, who was a Queen's Counsel appointed by the Governor-General, found that provincial counsel were, under the provincial law, given precedence over him, and he took the matter before, first, the Supreme Court of Nova Scotia $(m)$, which decided against him on the point as to the validity of the Acts as far as they merely gave the power to create Queen's Counsel, but for him on the actual point at issue, on the ground that the Acts did not permit retrospective action. The Supreme Court of Canada affirmed this judgment on appeal, but went much further, and declared that the provincial legislature was not competent to enact such a law, inasmuch as the Queen was no part of the provincial legislature, and no legislation passed by the legislature could affect the prerogative which was vested in the Governor-General only.

The decision, which was greeted with satisfaction in Canada, and was warmly approved by Mr. Todd, could only be held to be correct if the appointment of Queen's Counsel could be regarded as a conferment of an honour, and even then the difficulty would arise that the Governor-General has no anthority to confer honours. The Privy Council, in

(m) Canada Sess. Papers, 1877, No. 86, pp. $25-43 ; 3$ Can. S. C. R. 575. 
the case of the Att.-Gen. for the Dominion of Canada v. Att.Gen. for the Province of Ontario (n), overruled the judgment on the case of Lenoir $\mathbf{v}$. Ritchie, and decided that the power of the provincial legislatures to regulate the question of the appointment of Queen's Counsel was beyond doubt. They pointed out that the post was a sort of office, and that the right of pre-audience was really a matter not of precedence properly so called, but of arrangernents for judicial purposes, and they laid stress on the fact that the Queen, despite federation, remained an integral part of the legislature of every province.

But though the Governor-General has no delegation of the power conferring honours, the power is one which may, on exceptional occasions, be conferred on him ; for example, in 1879 the Marquess of Lorne received authority to appoint six members of the Privy Council of Canada to be knight commander's of the Order of St. Michael and St. George. In matters of precedence he has wider authority, as it was laid down by the law officers in England in reply to an inquiry (o) by the Governor of South Australia, in 18j9, that the residuary power of ordering precedence rested with the Governor in any case for which no provision had been made by other direction of her Majesty, and, in fact, the latest Colonial Office regulations leave entirely to the discretion of the Governor the precedence to be assigned to officials and other persons when not within the limits of the colony in which they have of right official precedence $(p)$.

The same list is worthy of note for one point $(q)$ : there still appears in the model list of precedence, by which in the absence of other provision the Governor is to guide himself,

(n) L. R. [1898] A. C. 247.

(o) South Australia Parl. Proc. 1871, App. No. 115.

(p) No. 142 (ed. 1908).

(q) No. 138. The bishop does not appear in the edition of the regulations in the Colonial Office List, 1908, p. 622. 
a reference to the precedence of the clergy, but the rule there laid down is stated not to have received as yet final approval. Under the older form the bishop took place immediately before the Chief Justice, and the table of precedence for the Dominion of Canada, as altered in 1893, placed members of the Cabinet after archbishops and bishops $(r)$, and the provisional table for the Commonwealth placed the cardinal and primate before even the Prime Minister of the Commonwealth. The colonial regulations do not, of course, directly affect any case in which the established list of precedence assigns no place to such dignitaries, but if retained it forms an exception to the rule of gradual dissociation of the Crown from all official connection with colonial clergy. Up to 1847 the precedence awarded to bishops was confined to Anglican clergy alone, but after that year, when precedence had been given in England to members of the Roman Catholic hierarchy, they were put, by the authority of the Secretary of State, immediately after the holders of similar rank in the Anglican Communion. In 1860 this was modified by direction of the Duke of Newcastle to assign to Roman Catholic archbishops precedence over Anglican bishops only when such office was admitted by bishops of either communion as regulating their relative rank. This superiority of the Anglicans disappeared for good after the decisions of the Privy Council, which led to the disuse of the practice of appointing colonial Anglican bishops by Letters Patent $(s)$, and those Colonies which assign precedence to prelates do so without distinction of religious belief. The retention of the precedence of the clergy is, however, purely a voluntary act on the part of the. Dominions, as it is essentially a matter. which the people of the Colonies must decide for themselves.

(r) Colonial Office List, 1907, p. 479.

(s) Long v. Bishop of Cape Tonn, 1 Moo. P. C. (N. S.) 411 ; In re Lord Bishop of Natal, 3 Moo. P. C. (N. S.) 115. 
It is also worth noting that of late years there had been a steadily increasing determination to give recognition throughout the Empire to the marks of distinction, viz., the title "Honourable," enjoyed by the colonial Ministers and legislative councillors. By a notice published in the "London Gazette," of June 16th, 1893, it was decided by her late Majesty that executive councillors and legislative councillors should be allowed to have the title "honourable," which is granted to them by custom in the colony in which they hold office, recognised throughout the British Dominions as long as they were entitled to hold it, and the same rule is applied in cases in which the title is continued under special circumstances after the termination of the active service of the holder of the designation $(t)$. Moreover, in the case of the federations, the Governor-General is, since 1900, addressed - like an ambassador or the Viceroy of India-as Excellency in communication from his Majesty's government; in other Dominions the title is merely local. Further, in the federations the title "Her Excellency" is given officially to the wife of the Governor-General.

One legal point may be noticed. The prerogative of honour is not a legislative act as exercised by the Crown, and grants contained in charters of justice (such as those in New South Wales and other States, the Cape, Natal, \&c.) are not legislative acts, but acts which can be altered at pleasure by the Crown, while if legislative acts they would, of course, fall under the principle of Campbell r. Hall (u). The question arises whether, if a colonial law provided certain rules, these could be altered by a prerogative act.

( $t$ ) After ten years' service as a legislative councillor (Circ. Desp., Nov. 14th, 1896), and usually after three years' service as an executive councillor. The members of the executive Councils of Canada, Victoria, Tasmania, Commonwealth, and the Cape do not vacate their seats, and so retain the title for life.

(u) Cf. also Jenkyns, British Rule and Jurisdiction beyond the Seas, p. 28. 
In my opinion, the answer must be decidedly in the negative. The prerogative cannot repeal an Act. The same position arises with regard to currency, where his Majesty can and has "legislated" for colonies with representative institutions. But though the question has been raised $(x), I$ can find no trace of any alteration of a colonial law by the prerogative. The real analogy is that of the Letters Patent and other instruments creating the appointment of Governor, \&c. They are valid so long as no law contradicts them $(y)$.

(x Cf. also Jenkyns, British Rule and Jurisdiction beyond the Seas, p. 28 ; Chalmers, Colonial Currency, p. 43.

(y) The prerogative of the Crown as to seals in the provinces of Canada is exhaustively dealt with in Canada Sess. Papers, 1877, No. 86. As to flags, see Colonial Regulations, Nos. 148-152 ; save in New Zealand, under an Act of 1901, the only flag of the Dominions for use on land is the Union Jack, though irregular use of other flags is not unknown. As to medals, ibid., No. 143; as to ealutes, Nos. 144-147; as to uniforms, Nos. 163-170. In all these matters the prerogative could be altered by legislation, while the rules as to flags depend on the Merchant Shipping Act, 1894. In minor respects these prerogatives are sometimes delegated; the prerogative of granting charters of incorporation is never delegated, and is still sometimes used in respect of the fominions, e.g., in the case of universities. Nevertheless, the title "chartered" can be given by colonial Act, as has been done in Ontario. 


\section{CHAPTER XIII.}

\section{CHURCH AND STATE.}

The strong grasp which the Anglican Church in England has upon the machinery of State has no parallel in the modern constitutional arrangements of the Colonies. Its power in civil matters has disappeared completely, and the precedence assigned to Anglican bishops, equally with those of the Roman Catholic communion, is almost the only trace of the former privileged position of the National Church in the Dominions. Only in Quebec is the hierarchy part of the State in any real sense $(a)$.

In the beginnings things were very different: the Act which gave Canada a new Constitution in 1791 partially established and partially endowed the Church of England by providing for the famous clerical reserves, the disputes over which form so large a portion of the early history of the colony. The Roman Catholic population naturally objected to seeing the endowment of the Anglican clergy, but their endowment was as much resented by the Protestants of other than the Anglican denomination, and matters became hopeless when the judges, called in to advise the House of Lords in 1840, gave a considered opinion that the endowment by the Act of 1791 was couched in terms large enough to include, and which did include, other clergy than those of the Church of England. By Acts of 1840 and 1853 the Canadian legislature obtained power to dispose of the endowment lands subject to the maintenance of existing rights, and

(a) Cf. Rerised Statutes, tit. ix ; Cauada House of Commons Debates, 1889, pp. 872 seq. 
an Act of the Parliament of the united provinces in 1854 gave over the lands to the municipalities, avowedly to remove all semblance of connection between Church and State $(b)$.

In Australia the framers of the early Constitutions were sorely vexed in spirit to provide for the maintenance of the influence and power of the Church. The bishop always served on the Council, and he was accorded a degree of consideration somewhat remarkable. The bishops naturally were rather opposed to the establishment of responsiblegovernment, which meant their disappearance from politics, and the question of creating clerical reserves in Australia appears to have been under consideration. Fortunately wiser counsels prevailed, but the question of the position of the clergy of the English Church in the Colonies remained very obscure until the delivery of the judgments of the Privy Council in the cases of the actions Long v. The Bishop of Cape Town (c) and In re Lord Bishop of Natal $(d)$. These two cases settled once and for all the position of the clergy in the Dominions. Up to 1865 the practice of the Crown had been to issue. Letters Patent for the appointment of colonial bishops, by which they were authorized to exercise jurisdiction in Church matters over the members of the Church of England in the colony. The former case dealt with the position towards his bishop of a clergyman in the Cape, the latter with the position towards the Metropolitan of a bishop in Natal whose Letters Patent provided that he was to be subject to the See of Cape Town, just as a bishop of any see within the province of Canterbury is subject to the Archbishop. It was laid down

(b) See Hincks, Religious Endowments in Canada (London, 1869), and Egerton, Canada, 1908, pp. 124, 169, 201-209.

(c) 1 Moo. P. C. (N. S.) 411.

(d) 3 Moo. P. C. (N. S.) 115. 
clearly by the Court that the Letters Patent in either case had no legislative force whatever. In both cases the Colonies concerned were conquered or ceded Colonies, and, if the Letters Patent has been issued before the grant of a representative legislature, the right of the Crown to confer jurisdiction in religious matters would have been beyond dispute, as the Crown has full legislative power over a conquered or ceded colony. But in both cases the Letters Patent dated after the grant of representative $(e)$ institutions to the Cape, and in accordance with the case of Campbell v. Hall $(f)$ the attempt to legislate by royal prerogative no longer could be successful. There remained, then, only the question whether in either case there could be implied a contract to submit to the quasi-jurisdictional powers of the bishop, and it was held that in the case of Mr. Long this might properly be inferred, but not in the case of Bishop Colenso. On the other hand, it was emphasised that the appointment itself was perfectly legal, and the Exchequer $(g)$ was found liable to pay the salary of the bishop, when it attempted to carry the decision to the logical conclusion that the bishop had no locus standi, while the Court expressly held that the title and precedence of a bishop were within the prerogative of the Crown to create anywhere.

The result of these famous decisions, which were justly admired at the time, at once reduced the position of the Anglican Church to an admirable simplicity, viz., that held by all other religious bodies in the Colonies, of voluntary associations for purposes of worship $(h)$. The ecclesiastical

(e) The judgment evidently means that, though it speaks only of an independent legislature. But a non-representative legislature does not exclude the prerogative, despite Anson, Law of the Constitution, II. 428.

(f) 20 St. Tr. 239.

(g) Bishop of Natal v. Gladstone, L. R. 3 Ex. 1.

(h) A Cape Aet (No. 5 of 1875), three years after responsible government, abolished the endowments of the Civil List Ordinance of 1852 .

K. 
jurisdiction did not disappear, but it ceased to be deemed part of the law of the land. It could not be executed in any other manner than by approaching a civil tribunal and asking that tribunal to enforce it, in the same manner as a tribunal may, if it think fit, enforce the decree of a Court of Arbitration. In fact, the matter reduces itself to a consideration how far those who join the Anglican Communion are bound by quasi-contract to fulfil certain obligations towards their spiritual superiors.

The Imperial Government, on the result of the cases in question being appreciated, determined to stop for good the issue of Letters Patent creating colonial bishoprics, and they applied this rule even to cases in which under the prerogative, as in conquered or ceded colonies, or by Act of Parliament, as by the British Settlements Act, 188i, the Crown has power to legislate, by Letters Patent, for the Colonies. Simultaneously the Crown renounced, of course, its control over the appointment of colonial bishops, whose choice now lay entirely in the hands of the churches. But in order for a colonial bishop to receive consecration from a bishop of the Anglican Church a mandate from the King is still necessary, which is applied for by the Archbishop of Canterbury, and which empowers the bishop in question to consecrate the proposed bishop, but which does not put forward any claim to confer the power of exercising jurisdiction of a properly legal character. But colonial bishops can and do freely consecrate other bishops $(i)$.

The result of the withdrawal of the Crown from any connection with the Church in the Colonies has been the growth of independent hierarchical bodies, which owe their juridical constitution to Acts of the local Parliaments, incorporating them and conferring on them certain powers. Their position is, therefore, precisely similar to that of the

(i) Cf. Anson, Law of the Constitution, II. 427-430. 
Anglican Churches of Scotland and of Ireland; they are independent of the Anglican Church in England, though they remain in communion with it and are on terms of close relation. But as was pointed out as early as $18 \pi 3$ by the Bishop of Wellington $(j)$, at the opening of his diocesan synod, the Church of England in the colony is " a branch of the Catholic Church, independent of all control from any other branch of the Church whatever. No other Church has any right to legislate for it. No appeal from its decisions can be carried to the courts of any other Church. It is in the same relation to the Church of England as the Church of Ireland, or the Church of America." In matters of doctrine, unlike the Anglican Church, the Privy Council has no authority over such a Church, save in so far as the Privy Council in interpreting a question of civil right, such as a trust deed, might find it essential to examine into the doctrines of the Church $(k)$. Like all voluntary associations it falls under the civil jurisdiction of the Courts, whenever questions arise either of the rights of the members inter se, or of the members and the outside public, but otherwise religion and the State are utterly separate.

There is, however, a real sense in which it may still be said that the royal supremacy exists. The Act 1 Eliz. c. 1, asserts for ever that the only power or jurisdiction within the realm, including all her Majesty's dominions, is annexed to the Imperial Crown, and specifically denies the right of any foreign potentate to intervene in affairs of either spiritual or temporal jurisdiction. This statement was especially mentioned in the Act of $17 \tau 4$, by which the Roman Catholics of Quebec were secured in the free exercise of their religion,

(j) Cited by Todd, Parl. Govt., p. 416.

(k) As the House of Lords had to do in the case of the Churches-Free and United Free-in Scotland: Free Church of Scotland (General Assembly of) จ. Oiertoun, L. R. [1904] A. C. 515. 
and the royal Instructions to the ill-fated Duke of Richmond on his appointment in 1818 as Governor-in-Chief over the two Canadas especially mentioned $(l)$ that the Roman Catholic Church was not to be given the position of an established church, and that "all appeals to a correspondence with any foreign ecclesiastical jurisdiction, of what nature or kind soever, be absolutely forbidden under very severe penalties." This state of affairs is still technically in force, and appeal to the Pope from Canada is illegal and unconstitutional. In point of fact, of course, the power of the Pope over Quebec is very great, and an ultramontane legislature actually paid to the Jesuits, in 1888, the value of the confiscated church lands in the Lower Province. The Dominion government made no attempt to interfere, on the ground that their action, however injudicious, was entirely a matter for the legislature of Quebec, though the matter raised a good deal of feeling in Parliament, and a motion for disallowance was brought in. Practically, from some points of view, the Roman Catholic Church might be deemed the Established Church of the province. But the greater part of educational difficulties in the provinces of Canada have arisen out of religious disputesthe Roman Catholic party insists on a special education for Catholic children, and the other side insist that such education should be provided at the special cost of the people who desire the unusual teaching, and not at the expense of the government. In New Brunswick, Prince Edward Island, and Manitoba the strife has been very serious, and in the latter case ended $(m)$ in the ruin of the Conservative government.

(b) House of Commons Papers, 1837-38, xxxix. No. 94, pp. 71, 72; 31 Geo. 3, c. 31 , s. 35 ; cf. Egerton, Canada, pp. 332,333 ; and for education, ibid. pp. 319 seq. ; and for the Quebec Act, Lefroy, Legislative Power in Canada, pp. 223, 224; Canada House of Commons Debates, 1889, pp. 812 seq.

(m) Canada House of Commons Debates, 1896. 
In Natal there still remains a small remnant who belong to the Church of England proper, as distinguished from the autonomous Church in communion with the Anglican Church which arose as a result of the decision in Bishop Colenso's case. It cannot, however, long survive the fact that it has no bishop to ordain priests, as, despite several appeals, the Archbishop of Canterbury does not feel entitled to encourage a rival body to the Church which is in communion with the Anglican Church (n). Similar autonomous Churches exist in all the other Dominions. But in Newfoundland a considerable measure of political power rests with the Roman Catholic archbishop $(o)$. There was recently published in the papers of the colony an interesting dispute as to his Grace's action in the matter of the proposed appointment to the executive council of a member of Parliament, who is now in opposition. It was freely asserted and admitted that the archbishop was asked to secure the appointment of the gentleman in question, and that he was ready to do so. Except in Quebec there can hardly be any parallel for so strong religious influences being brought to bear on a political issue. And in Canada, it must be remembered, the Supreme Court has unanimously held that an election for the Dominion Parliament was void because of the interference of Roman Catholic priests with the voting of their parishioners $(p)$.

(n) Parl. Papers [C. 5489].

(o) Evening Telegram, Jan. 24th and 25th; Daily News, Jan. 27th; Evening Chronicle, Jan. 24th, 1908.

(p) Brassard el al. v. Langevin, 1 Can. S. C. R. 145. 


\section{CHAPTER XIV.}

JUDICIAL APPEALS.

IT is now fully established $(a)$ that the Crown is entitled to hear appeals from the decisions of all colonial Courts, save in such cases as the prerogative right has been expressly taken away by legislation. This right in the main rests on the prerogative of the Crown as, in the last resort, the fountain of justice, and preserves in a new form the jurisdiction of the King in his Council. The statutes affecting the constitution of the tribunal before which the appeals are held for the most part merely recognise the appeals as existing, and do not purport to give them legislative sanction, but the Act 7 \& 8 Vict. c. 69 , s. 1, does expressly overrule any limitation on the power of bringing an appeal direct from inferior Courts in the Colonies, there having formerly existed restrictions on the bringing of appeals from Courts other than Courts of error or appeal. But though, strictly speaking, appeals can be brought direct from any Court with the permission of the King in Council, such appeals are practically never allowed save in cases like those of the Canadian provinces, or the Australian states, where the Court from which appeals are brought, though, no doubt, not the highest Court of Appeal available, since appeals can be brought to the Federal High Courts, is still in itself of the status of a Court of Appeal (b). There are, of course, the strongest grounds of convenience

(a) Most recently in In re Wi Matun's Will, L. R. [1908] A. C. 448.

(b) But cf. Sir R. Stout's complaint in Parl. Papers [Cd. 3524], p. 195. 
and policy in favour of this mode of procedure; the Judicial Committee is not to be troubled with minor cases, or with cases which have not received the fullest consideration from the Courts below.

Similar grounds of convenience render it essential that criminal appeals should be very rare. They are by no means unknown, but the established rule is that they shall be received only when some grave matter of principle is involved, which would be likely to act as a precedent for the future, and which seems to result in some substantial and serious injustice. Appeals on mere points of form or technical inaccuracies are never allowed, even in civil cases. A further prevention of the bringing of criminal cases lies in the fact that in each instance at present special leave to appeal is required, and no colonial Court has now any authority to grant leave to appeal. In the Dominion of Canada a further step has been taken, and under a Canadian Act of $1887(c)$, which was duly sanctioned, the power of the Privy Couneil to grant leave is formally taken away, so that in criminal matters no appeal at all lies from the Supreme Court of Canada to the Judicial Committee.

In civil cases appeals are of two kinds, either by right under conditions framed by local legislation or by Order in Council, or by special leave. Appeals as of right are usually permitted only in cases where the subject-matter involved is of considerable value, the amount varying from 500l. to 2,000l. in different Colonies, according to their social conditions, and only from final decisions. Notice of appeal has to be lodged within a certain period, and security given for the payment of costs, \&c. Where the conditions are fixed by local Act, the limitations are imposed, of course, as part of the ordinary law of the colony. In some cases the

(c) See now Revised Statutes, 1906, c. 146, 8. 1025. 
limitations are fixed by imperial charters which have legislative effect, either because they were issued in virtue of the prerogative of legislation for conquered Colonies, or because they have been confirmed by Imperial Acts. In other cases they are limited by Order in Council, made under the distinct prerogative right to decide at the pleasure of the Crown the conditions on which the right to receive appeals will be exercised, and it is still open to his Majesty to limit in this way the right of appeal from the Courts of self-governing Colonies over which he has no legislative power.

Appeals by special leave are subject to no conditions whatever beyond those applied by the Judicial Committee on the occasion of each appeal. They will only be allowed when some substantial issue is at stake, but if that is established they will be granted even if the sum involved is trifling. But in all cases appeals will not be decided if the grievance in question has been removed, whether by legislation or otherwise, since the appeal was entered, as the Court exists for the consideration of substantial grievances only $(d)$.

The jurisdiction of the Privy Council has not gone unquestioned of recent years; doubts have freely been expressed of its competence to deal satisfactorily with the complicated questions of colonial law brought before it, and stress has been laid on the desirability of having local points of law settled locally. Stress has been laid in reply on the advantage of having a neutral tribunal to decide matters which may raise great political feeling in a colony, while steps are being taken to revise and simplify the procedure of the Court, and advantage has been taken of the power to

(d) Cf. Tarring, Law relating to the Colonies, ed. 3, Chap. V.; L. R. [1908] A. C. 214 (a very extreme case). Other rules are that an appeal from the Superior Court of Canada or the High Court of Australia will only be allowed on very grave grounds, and scarcely at all if the appellant has taken a case from a Superior Court of a province or state to the Federal Court. Cf. Daily Telegraph Newspaper v. M'Laughlin, L. R. [1904] A. C. 777. 
add colonial judges given by the Act of 1895 to appoint to it members of the bench of the Dominions. Too much need not be made of its value in preserving a general uniformity of law throughout the Empire, for not only is the system of English law which the Court knows best not in force in South Africa and Quebec, but also much of recent colonial legislation has been directed towards the alteration of the fundamental principles of the English common law. On the other hand-and this is often overlooked - the Court does perform an invaluable service in constitutional matters. Its judgments form a standard by which questions of the relations of Imperial Acts and local legislation can be regulated throughout the Empire, and, just as a Supreme Court is a necessary adjunct to a federation, the existence of the Privy Council seems essential to an Empire. Moreover, the Court can alone deal satisfactorily with the doctrine of the royal prerogative. The prerogative, it has been repeatedly laid down (e), is the same all over the Empire, except so far as it has been lessened by local legislation (which includes a code of law introduced by tacit or express act in a ceded colony like Mauritius, or a conquered colony like Quebec) binding the Crown, and, if so, one Court is required to set forth consistently its nature.

These theoretic arguments were not accepted by the framers of the Australian Constitution, and in the shape in which the Australian Constitution Bill was presented to the British Government every question affecting the interpretation of the Constitution of the Commonwealth or of the States was excepted from appeal to the Privy Council, save when the public interest of some other part of his Majesty's

(e) Cf. L. R. [1892] A. C. 437, at p. 411 : Col. Gort. v. Laborde, Mawritius Supreme Court Decisions, 1902, pp. 20 seq. (with which, as explained above, I agree, but not with the dicta of the Court as to treaties). 
Dominions was involved $(f)$. This clause caused a good deal of discussion and dispute, but eventually the government accepted a compromise which excluded from the category of appealable cases all those involving the rights inter se of any state or states and the Commonwealth or of any states, except if the Court should decide to grant a certificate providing that the matter was one on which an appeal to the Privy Council should lie. In other matters no appeal lies of right to the Judicial Committee, but the prerogative right of granting special leave remains untouched, in this respect resembling the case of Canada, where no appeal lies of right from the Supreme Court.

It was pointed out in the Parliamentary Debates in England at the time that the provision would lead to serious confusion and inconvenience, in view of the fact that the appeal from the State High Courts remained unaffected by the Act, which merely added an appeal to the High Court of Australia as an alternative mode of procedure, but did not abolish the appeal to the Privy Council. It was shown that a case involving issues between two states, or a state and the Commonwealth, might be taken to the Privy Council and decided in one sense, while a similar case carried to the High Court would be decided in the opposite sense $(g)$. In reply, it was argued very confidently that the High Court, being generally subject to having its judgments revised by the Privy Council, would accept the decisions of the latter as binding. The argument was not at all cogent, inasmuch as it was the view of the framers of the Act that the provisions should secure the decision of Australian constitutional questions by the High Court, and in fact the High Court, on the

(f) See Commonwealth of Australia Constitution Bill Debates, \&c. (Wyman's, 1901).

(g) Ibid. pp. 25, 26, 109 (Lord Russell of Killowen), 101 (Lord Darey), 67 (Mr. Haldane). 
occurrence of such a dispute, refused to accept the view of the Privy Council $(h)$. The dispute arose out of the question whether a state government could levy income tax on the income of a federal official. The Privy Council held that it obviously could, as its powers of taxation were not affected in this regard by the Constitution; the High Court held that it could not, inasmuch as the use of the power might conceivably enable the states to paralyze the action of the Federal Government, an argument used in the United States by Chief Justice Marshall ( $i$ ). The position was absurd, and the solution amusing. The Federal Parliament in $190 ;$ hastily passed an Act providing that the states could levy income $\operatorname{tax}$ on the salaries of Commonwealth officers, though if, as the High Court held, the Constitution forbad this, the change should have been made by a formal amendment of the Constitution, which, however, would have involved much trouble and delay. More satisfactory was its remedy for future disputes. It passed an Act under the power expressly given to it by the Constitution $(k)$ of deciding what Courts should exercise federal jurisdiction, a term including any question arising out of the Constitution. This Act does not deprive the appellant in a state Court of the right assured to him by the royal prerogative of appealing from any final decision whatever of such a Court, but it does secure that no state Court shall ever give a decision ou any matter involving the rights inter se of the Commonwealth or states or two states, by providing that any case in which such issues are raised shall at once be transferred to the High Court, when, of course, the clause of the Constitution limiting appeals to the

(h) Ibid.pp. 113 (Lord Selborne), 117 (Lord Alverstone), 85 (Sir R. Finlay).

(i) See Deakin v. Webb, 1 C. L. R. $585 ; W_{e b b}$ v. Outtrim, L. R. [1907] A. C. 81 ; Baxter v. Commrs. of Taxation, New South Wales, 4 C. L. R. 1087; Flint v. Webb, ibid. 117S; and the last two cases on appeal in the Privy Council, 5 C. L. R. 398 ; L. R. [1908] A. C. 214.

(k) Sect. 77 (2). 
Privy Council from the High Court will come into operation. The device is ingenious, and terminates satisfactorily a position which threatened to become a nuisance (l).

While the Commonwealth Constitution Act only limits in this one point the right of the Council to grant special leave to appeal, it expressly permits the Commonwealth Parliament to legislate, imposing further limitations, subject to the proviso that any such legislation must be reserved for the consideration of the Home Government. It has been argued from this express permission and also on general grounds that the rule is that, save by Imperial Act, there is no power in a colonial legislature to limit in any way the royal prerogative, at any rate, as far as appeals are concerned. This view, however, is not tenable, for it ignores the existence of the Canadian Act of 1887, abolishing all appeals by special leave on criminal matters from the Supreme Court of Canada, the validity of which has never been questioned by the Imperial Government. Not on more general grounds does it appear possible to maintain the doctrine; there is no special sacredness about the right to grant leave of appeal to exempt it from change by a colonial Act sanctioned by the Governor, and not disallowed by his Majesty's Government.

There is, however, one whole class of cases, which is exempt from the ordinary rule of judicial appeal. In Théberge v. Laudry $(m)$ the appellant had been elected a member of the Legislative Assembly of Quebec, and had afterwards been unseated by the .Superior Court on grounds of corrupt practices. The Corrupt Practices Act of Quebec, under which proceedings were taken, provided that the decision of the Superior Court in such a case should not be susceptible

(l) Cf. my article, Journ. Soc. Comp. Leg., 1908.

(m) L. R. 2 App. Cas. 102. Cf. Holmes v. Angwin, 4 C. L. R. 297 ; and ef. Moses v. Parker, Ex parte Moses, L. R. [1896] A. C. 245. 
of appeal, and special leave to appeal was refused. The ground of the refusal was explained in the subsequent case of Cushing v. Dupuy $(n)$ as depending entirely on the peculiar character of the subject-matter of the appeal, and not on the words of the statute, which did not purport to limit the prerogative. The duty of deciding upon disputed elections is not one which properly devolves on the executive power or is part of the royal prerogative, and accordingly the Privy Council was not desirous of extending its scope to the consideration of cases of this kind. The Commonwealth High Court has adopted the same doctrine.

Various suggestions have of late been under consideration for a change in the nature of the final Court of Appeal for Dominion appeals. In 1902, at the Colonial Conference of that year, some stress was laid on the suggestion that there might be created a Court of final appeal for the whole Empire, including the United Kingdom, there being a general impression in the Colonies that the Privy Councillors, who are also members of the House of Lords, devoted more attention to their duties in that Court than in the Judicial Committee. The suggestion was not, however, found to be practicable, as the legal authorities of the United Kingdom were not desirous of making any alteration in the composition of the House of Lords as a Court of Appeal, and at the Colonial Conference of 1907 it was frankly admitted that no change was in contemplation as regards the composition of the tribunals. It was, however, agreed that it was desirable to consolidate and simplify the practice of the Privy Council as regards appeals, and plans to effect this end are under consideration. Some resentment against the Privy Council was created in 1903 in New Zealand by the terms of a decision of their lordships in the case of Wallis $\mathrm{v}$. The

(n) L. R. 5 App. Cas. 409, Cf. In re Wi Matua's Will, L. R. [1908] A. C. 448 . 
Solicitor-General of New Zealand (o), where the Privy Council passed strictures on the colonial Court as being too ready to yield to executive control, a charge indignantly repudiated by the Court, which retorted on the Privy Council by accusing it of delay in giving its decisions, of ignorance of the laws and circumstances of the colony, and so forth, and the feeling of discontent with the Court is clearly still alive to-day in the Dominion, though not shared by the Government.

On the other hand, in the recent negotiations for the foundation of a federal union in South Africa, the principle of maintaining the supreme authority of the Privy Council has been maintained. It is there proposed that no direct appeals to the Privy Council should be allowed from any Court save the final Federal Court of Appeal itself, and in all probability the appeals from that Court will only lie as a matter of grace on special leave being granted by the Privy Council. But the right to grant such special leave will not be curtailed in any way, thus leaving the Privy Council to perform the same useful services to South Africa as to the Dominion of Canada as regards the interpretation of the Constitution.

It is, however, possible that in this and other cases there may be a delegation to the colonial Courts of part of the prerogative to grant special leave to appeal. The present procedure of a reference to the Privy Council for leave, and then the actual hearing of the appeal, is clumsy in the extreme, and a change would seem on all grounds desirable and free from objection, it remaining always with the Privy Council to grant special leave, even where a lower Court could have granted such leave and has refused so to do.

Besides its powers of hearing appeals, the Privy Council

(o) L. R. [1903] A. C. 173. See also all the complaints in Parl. Papers [Cd. 3524], pp. 179 seq., and the discussion in [Cd, 3523], pp. 200-230. 
has an extraordinary power of deciding matters referred to it. By sect. 4 of the Act $3 \& 4$ Will. 4 , c. 41 , the King may refer to the Judicial Committee any matter other than appeals which his Majesty may think fit, and the Committee is bound to consider and decide the matter as if it were a legal appeal. The chief use of this section in colonial matters has been in connection with the removal of colonial judges on petition from the colonial legislature, as in the case of the Representatives of the Island of Grenada v. Sanderson $(p)$, but the same power has been used with especially useful results in the case of disputes between provinces in Canada; for instance, in 1878 the Privy Council adjudicated on the jnint request of the governments of Ontario and Quebec on certain disputes as to the division of assets and liabilities between the two provinces, and the dispute between the governments of Newfoundland and the Dominion as to the exact boundaries of Labrador will be settled in this manner $(q)$. The advantages of the procedure are obvious, because there is thus obtained a definite ruling on the whole matter at issue, while in any individual case the matter is presented in connection with a particular subject-matter, which renders the Court unable to arrive at any general decision. On the other hand, the Crown will not refer matters to the Committee, unless they are such that the Committee has a proper right to intervene. For example $(r)$, in $18 \pi 2$ the government refused to refer to the Council the question of the fact whether certain enactments of the legislature of New Brunswick on the subject of schools were such as to give the Dominion Parliament power to pass remedial

(p) 6 Moo. P. C. 38 ; cf. also Mr. B. Walker's case, Times, Nor. 6th, 1908.

(q) Cf. also Tarring, Law relating to the Colonies, ed. 3, p. 204, n. 1; Harrison Moore, Commonwealth of Australia, pp. 241, 242 ,

(r) Cited in Parl. Papers [C. 2445], p. 121. 
legislation under sect. 93 (4) of the British North America Act, 1867, on the ground that the Queen in Council had no power to determine the matter, and the decision given would not be binding on the parties in Canada. So, in 1879, the Secretary of State declined to refer to the Privy Council the question of the right of the Dominion Government to dismiss the Lieutenant-Governor of Quebec, because the Dominion Government were not a party to the request for a reference, and the reference would not have bound them $(s)$.

It is, indeed, technically correct to say that, even in the case of a joint reference, the decision is not legally binding on the parties; but in effect it would be binding, inasmuch as any action taken under it would no doubt be held by the Privy Council to be legal or not, so far as it was in conformity with its decision. It is true that the Privy Council is not bound by its own decisions, but there is practically no probability of it ever upsetting a decision arrived at on an agreed case, in which presumably all the relevant facts would be given $(t)$.

(s) Cited in Parl. Papers [C. 2445]; cf. [C. 5489], p. 14.

$(t)$ For this chapter, ef. Safford and Wheeler, Privy Council Practice, 1901. 


\section{CHAPTER XV.}

\section{THE JUDICIARY.}

Ir necessarily follows, from the nature of the relation between the Dominions and the Mother Country, that the utmost importance attaches to the independent position of the judicial authorities of the Dominions. The supremacy at once of the Imperial Parliament and of the colonial Constitution over the ordinary colonial legislation are dependent for their actual effect on the decisions of colonial Courts. It is true that wrong decisions on these points can be reversed on appeal by the Privy Council, but the cost of appealing to that tribunal would certainly in many cases preclude such action, and the essential consideration for the suitor is that he should be able to receive redress without undue delay and cost. This result undoubtedly is contributed to by anything which gives judges security of tenure; the mere fact that a judge cannot be removed by the executive has an excellent result in opening his mind to receive more general considerations than would naturally present themselves to an executive officer. A member of a colonial Ministry is naturally more anxious to give effect to the poliey determined upon by his colleagues and himself than to secure the rights of those who may oppose his schemes, and in such cases it is too much to expect that powers would not be strained, if it were possible by ordinary executive action to remove the offending judge.

The judiciary in all the Dominions has accordingly been adequately protected against hasty dismissal by the executive

$\mathbf{K}$. 
government under the terms of the Constitution Acts. In Canada (a) the judges of the Supreme Court, the Court of Exchequer, the Superior, District and County Courts in the provinces, save the Courts of Probate in Nova Scotia and New Brunswick, are appointed by the Federal Government to hold office on good behaviour, but subject to removal in the case of judges of the Superior Courts by the GovernorGeneral on an address from the Senate and House of Commons. Provision has also been made by a Canadian Act $(b)$ for the removal of other judges on grounds of illhealth, old age, or inability to perform their duties, or from incapacity or misbehaviour; but in these cases due notice must be given to the judge of the charges, and they must be investigated by a commission of enquiry which consists of judges. This provision thus allows judges to be retired with less difficulty than by the more formal method of addresses by Parliament, but the procedure amply safeguards the interests of the judges $(c)$.

In the case of the Commonwealth $(d)$ the Constitution expressly lays down that the judges shall be appointed by the Governor-General in Council, and shall only be removed by the same authority, on addresses having been presented by both Houses of Parliament in the same session praying for removal on the ground of proved misbehaviour or incapacity, while their salaries cannot be diminished during their tenure of office. It will be noted that proved misbehaviour or incapacity is necessary, and the question arises by whom the proof is to be obtained. Probably, in any such case, there would be a preliminary investigation by a commission appointed ad hoc

(a) British North America Act, 1867, ss. 96, 99.

(b) Revised Statutes, 1906, c. 138, 8. 28.

(c) In the last resort the judiciary is dependent, as in England, on the legislature. Cf. Harrison Moore, Commonwealth of Australia, p. 279.

(d) $63 \& 64$ Vict. c. 12 , s. 72 of Schedule. 
by the Parliament, as was done in Canada in cases of proposed removal in 1867 and 1877 .

The provisions in the case of the Commonwealth have been followed in the case of the Transvaal and the Orange River Constitutions in their entirety except that the address contemplated by the law is a joint one from the two Houses. There is the same mention of proved misconduct or incapacity, and again the mode of proof is left for the legislature to decide. Presumably the legislature would embody in its address a statement that the misbehaviour or incapacity had been proved, and such a statement would be sufficient for the Governor in Council to act upon $(e)$. In the case of Victoria and Tasmania the power to remove is only to be exercised, on an address, by the Governor, not the King, and no mention is made of grounds being given.

In all these cases the decision as to dismissal must rest in the last instance with the Governor advised by his Ministers, for there is no compulsion put on the Governor to dismiss; the powers given are merely enabling, and a Ministry might conceivably find it necessary to disregard the wishes of Parliament, and a Governor could only dismiss them and find other advisers. The Governor, however, could not refuse compliance with their advice except under the usual conditions, either because of an imperial duty, or because he thought it was not the real wish of the country, and that he could obtain new advisers with a majority in the constituencies.

The position of the Imperial Government is somewhat different in the remaining Colonies. In them the rule is that judges should hold office during good behaviour, and that their salaries should not be diminished during their tenure of office, but that they should be removable by the Crown on the address of both Houses of Parliament. Provisions to this

(e) Cf. Harrison Moore, Commonicealth of Australia, p. 279; Transvaal Letters Patent, 1906, s. 48; Orange River Colony Letters Patent, 1907. s. 50. 
effect exist in the Constitutions of Newfoundland, Natal, New Zealand $(f)$, New South Wales, South Australia, Western Australia, and Queensland $(g)$. These provisions differ from those in the Constitutions of the Federations, of Victoria and Tasmania, and of the new Colonies which are based on those in force in the Commonwealth, in two important respects, viz., the power to remove is given to the Crown, not to the Governor, and no mention is made (as also in Victoria and Tasmania) of any grounds being required for removal.

It is apparently open to any Parliament to ask the Crown to dismiss a judge on whatever grounds seem to it adequate, and no allegation of proved incapacity or misbehaviour is required on which the address to the Crown should be based. In England, on such an address being passed by the Parliament, the matter would be ended and the removal of the judge would follow as a matter of course; this, however, it was decided in the case of Judge Boothby of South Australia $(h)$, was not the case in a colony where the power lay with the Crown. It was the duty, it was held, of the Crown to assure itself that the grounds on which the removal was asked for were adequate. Even in England, it is usually laid down that the address should recapitulate the grounds on which the removal is asked, though there are no recent cases of such addresses being moved, a threat of an address usually sufficing. In the case of colonial judges it may in future be assumed that they will not be petitioned against by a colonial Parliament, save on sufficient grounds ascertained judicially by a commission of enquiry by the direction of the Parliament, so that any use of the royal power of refusing to act on a petition will be unnecessary. But in law, the fact remains that the removal is not a mere ministerial act, and

(f) See Supreme Court Judges Act, 1858, and 15 \& 16 Vict. c. 72, s. 65.

(g) See Supreme Court Act, 1868 (31 Vict. c. 23), s. 9.

(h) Cf. Todd, Parl. Govt. p. 848. 
probably the suggestion of Sir Frederic Rogers $(i)$ in his memorandum of 1870 on the removal of colonial judges, that the case would be at least formally referred to the Judicial Committee for report, would be acted upon. If the procedure appears anomalous under responsible government, it is really no more so than the rule that the decision whether or not to grant a fiat in a case of a Petition of Right against a colonial government is still vested in the Imperial Government. The anomaly, in either case, can be removed by legislation in the colony or by imperial legislation, if deemed desirable.

As a mere matter of law there seems no reason to doubt that the provisions of Burke's Act $(j)$, under which the Governor in Council can amove any colonial officer, still applies to judges of the Dominions. The Act applies only, it would seem, to offices held during good behaviour, as decided in the case Ex parte Robertson $(k)$, where it was held that the Act did not apply to the case of the dismissal of the Commissioner of Lands in New South Wales, that officer holding merely during pleasure. An appeal from such amotion lies to the Privy Council, but it is somewhat doubtful whether the Act really applies to any officers appointed otherwise than by Letters Patent under the Great Seal of England, as at the time of the passing of the Act that was the normal mode of appointing the officers whose interests it was apparently intended to conserve by the Act, but, in discussing the question in 1870, the Privy Council did not discriminate between appointments by colonial and English patents; and a further piece of evidence in farour of the view that any patent is sufficient to bring an officer within the purview of the Act is afforded by the fact that in the Natal

(i) Purl. Papers [C. 139]; 6 Moo. P. C. (N. S.) App. IX.

(j) 22 Geo. 3, c. 75 . The attempt to repeal tha Act, as regards Tasmania, by 20 Vict. c. 7 , is, of course, ineffectual.

(k) 11 Moo. P. C. 288. 
Constitution Act of 1893 there was expressly sared any right of appeal to the Secretary of State which any officer possessed before the coming into force of the Act, apparently a vague and confused reference to the special position of patent officers $(l)$.

In the case of the Federations and Victoria it is very doubtful if such removal would be possible as the Acts go beyond the ordinary provisions and expressly contemplate removal only by the Governor-General in Council or Governor on the necessary address being passed. In the case of Tasmania and the two new Colonies, however, as their Constitutions rest merely on a local Act and Letters Patent, the provisions of the Imperial Act remain in full force and would override the Letters Patent. It is conceivable, but not likely, that the procedure laid down in the Act may sometimes be followed: it gives, however, a legal appeal to the Privy Council, and this would probably prove a bar to its acceptance by any colonial government.

In addition to the security against dismissal given by the various Constitution Acts, the Courts are protected by the fact that the executive power cannot increase the number of judges so as to influence the decision of any case. The creation of an additional judge is now so regulated by Acts in all the Dominions that, whatever the prerogative rights of the Crown may be in England, the increase of the colonial bench would in all cases require an Act of the legislature, and obviously if such an Act were possible it would be equally

(l) In the case of Newfoundland, judges used to hold at the pleasure of the Crown, under the Act 5 Geo. 4, c. 67, and could be removed by the Crown; presumably a petition from the legislature would have been the correct form, as in Chief Justice Boulton's case. In the case of the Cape, judges can be suspended by the Governor in Council and removed by the Crown. See Charter of Justice (Vol. I. p. 95, of Consolidated Statutes, 1652-1895). 
convenient to pass legislation bearing on the precise point at issue $(m)$.

The presence of colonial judges on the Judicial Committee of the Privy Council is provided for by an Imperial Act $(n)$.

Like English judges, colonial judges are immune from suits $(o)$ in respect of acts-even if oppressive and maliciousdone within the sphere of their jurisdiction $(p)$.

(m) Cf. Buckley v. Edwards, L. R. [1892] A. C. 387.

(n) 58 \& 59 Vict. c. 44, amended by an Act of 1908.

(o) Anderson v. Gorrie, L. R. [1895] 1 Q. B. 668.

(p) For the tenure of judicial office in Natal, see Act No. 14 of 1893, 88. 43-45; in Newfoundland, Act No. 3 of 1904, s. 6 ; in New South Wales, 18 \& 19 Vict. c. 54, Sched. ss. 38, 39; in South Australia, Act No. 2 of 1855-1856, ss. 30, 31 ; in Western Australia, 53 \& 54 Vict. c. 26, ss. $54-56$; in Victoria, 18 \& 19 Vict. c. 55 , ss. 38,39 ; in Tasmania, 20 Vict. c. 7 . The reasoning of the law officers, followed in Todd, op. cit., p. 843, as to Burke's Act still applying to Victoria, seems vitiated by neglect to note that the power of removal there rests with the Governor, not the Crown. The case of Queensland (ibid., p. 836) is different. 


\section{CHAPTER XVI.}

\section{IMPERIAL CO-OPERATION.}

THE system of government which has been sketched in the preceding chapters is one of marked individuality. Its leading characteristic has no real historical parallel: [no power, except Great Britain, has ever consented to foster the growth of great communities, which for every practical purpose are allowed to mould their own policy, and which $\checkmark$ yet are exempt from the obligation of self-defence. It is true that this freedom carries with it certain limitations; in the long run the Imperial Government controls foreign policy, but, as has beez seen in Chapter $\mathbf{X}$., that Government is ever ready to secure any possible concessions desired by Dominion governments.] Stress has been laid on the failures of the Imperial Government to acquire various foreign lands for the Empire, but it is well to remember that the loss of the territory which is now German South West Africa was due to the delay of the Cape Government to undertake the pecuniary responsibility of maintaining the administration $(a)$; that British New Guinea was annexed as soon as the Australian Colonies were prepared to accept financial responsibility $(b)$, and that the failure of British attempts to secure the New Hebrides have not been unconnected with the lack of encouragement given to the British settlers by the Commonwealth tariff as against the protection given by the
(a) Parl. Papers [C. 4190], [C. 4262], [C. 4265], [C. 4290].
(b) Ibid. [C. 3617 ], [C. 3691], [C. 3814], [C. 3839], [C. 3863], [C. 4287], [C. 4273], [C. 4290], [C. 4441], [C. 4584], [C. 4680], [C. 5564]. 
neighbouring French Colonies $(c)$. (Nor can there be a more signal proof of the weight of the Dominions in the counsels of the Empire than the fact that the "White Australia" policy has received the endorsement of the Imperial Government.]

[Recognition of the actual share of the Dominions in directing the policy of Empire has been shown by the contributions to the Imperial Navy given by Australia, New Zealand, the Cape, and Natal.] Australasia led the way in 1887, when, at the Conference of that year, it was agreed that the Colonies should contribute annually 126,000l. to the navy in return for the addition of five fast cruisers and two torpedo gunboats to the Australasian squadron $(d)$. In 1897 the Cape offered to supply gratis a battleship, an offer afterwards altered into a free contribution of $30,000 \mathrm{l}$. a year, to which Natal added 12,000l, , also a free contribution $(e)$. In 1902 , as the result of the Conference of that year, the Australasian contribution was raised to $240,000 l$, for which a larger force was to be maintained, while the Cape and Natal raised their contributions to 50,000l. and 35,000l. a year respectively $(f)$. At the Conference of 1907 a change of opinion appeared in the riews of the Commonwealth Government, which desired to devote all its payment to local defence: the question is still under discussion with the Admiralty, and every aspect, constitutional and naval, is adequately dealt with in the Commonwealth Debates for 1908 , in which special stress was laid on the declaration of the Prime Minister of Great Britain, in welcoming the Imperial Conference of 1907, that the obligation of the Imperial Government to defend the Dominions was not conditional on any contributions from those Dominions, and

(c) Ibid. [Cd. 3288]; see especially pp. 63, 64, as to Samoa.

(d) Ibid. [C. 5091].

(e) Ibid. [C. 8596$]$.

(f) Ibid. [Cd. 1299]. See Australian Naval Agreement Act of 1903. 
was a necessary corollary from the imperial control of foreign affairs $(g)$. The Cape and Natal have also arranged to appropriate part of their subsidies to the encouragement of local naval reserves, while, since 1902, Newfoundland has paid 3,000l. a year towards the cost of a naval reserve there. New Zealand, on the other hand, by an Act of 1908, has increased, from 40,000l. to $100,000 \mathrm{l}$. a year, her contribution to the Imperial Navy, and has expressly disclaimed any idea of making the increase conditional on local defence.

[The problem of defence and of control of foreign policy is as yet not capable of solution : the Dominions_are relatively too weak as compared with the mother-country to render any. federation reasonable, and nothing save federation promises to solve the problem. In the meantime value attaches to the growth of the system of co-operation between the different parts of the Empire, which has been increasing in strength of late years. The assistance given in men by the Colonies during the Boer war has been an essential feature in the consolidation of the Empire, and $\mathrm{Mr}$. Lyttelton readily acknowledged that the governments of the Colonies were entitled, both generally and also on this account, to express an opinion on the subsequent introduction of Chinese labour into South Africa $(h)$, while there is a very significant change in tone between the replies once sent to "Home Rule" petitions from the Colonies and those recently returned to Canada and Australia $(i)$. The same tendency shows itself in the final passing of the imperial legislation, first removing any legal disability from the children of-marriages with a deceased wife's sister, legal in the Colonies but not in England $(k)$, and then abolishing the civil disabilities in England itself.

(g) See Parl. Papers [Cd. 3523] (on p. 5 of which will be found the Prime Minister's speech), [Cd. 3524], [Cd. 4325].

(h) Ibid. [Cd. 1895], pp. 54, 223 (Cape), 231, 327 (New Zealand).

(i) Cf. Ibid. [C. 3294], with [Cd. 1697], [Cd. 2821], [Cd. 3159], [Cd. 3187].

(k) Ibid. [Cd. 2398]. 
The formal expression of this spirit of co-operation is seen in the Colonial Conferences. The first, that of 1887, was a very informal body, and included statesmen of varying degrees of importance who happened to be in London for the late Queen's Jubilee. Its most important work was its discussion of colonial defence, and the inauguration of the Australasian contribution. The next Conference, that of 1897, was a much more formal body and included only representatives of the several governments of the responsible government Colonies, viz., the eleven Prime Ministers invited to the celebrations of the sixtieth year of her Majesty's reign. It was then definitely decided to hold future Conferences. This resolution was carried out in 1902, when a formal Conference was held, advantage being taken of the Coronation of the King to assemble the Prime Ministers of the various Dominions along with other leading Ministers. No invitation was given to the Australian States, a proceeding protested against, in 1907, when the next Conference was held. That Conference resulted in the important decision to render permanent the constitution of the Conference, at the same time changing its title to that of " Imperial Conference,"-and constituting the Prime Minister of Great Britain ex officio President, the Secretary of State for the Colonies taking the chair in his absence. Henceforth the meetings are to be held every four years, and a secretariat under the control of the Secretary of State is to attend to the business of the Conference between its meetings.

Proposals have been made for going further than this, and Mr. Lyttelton, in a despatch of 20th April, 1905 (l), proposed for consideration the creation of an.Imperial Council, which would have had a permanent existence and included on it re. presentatives from the Dominions. But for this step opinion

(l) Ibid. [Cd. 2785], [Cd. 2975], [Cd. 3523], [Cd. 3795]; cf. Times, Oct. 17th, 1904. 
in the Dominions was not prepared, and in special, great stress was laid by the Prime Minister of Canada, the greatest of all the Dominions, on the danger of setting up any authority, which could in any way seem to infringe on the self-government of the Dominions. The views of Australia were more advanced; but clearly any such scheme depends for its effect on unanimity, which at present at least is not attainable.

The actual work - done by the - Onferences may be deemed not very great; and it is true that nothing very sensational has resulted. On the other hand, such discussions are of great advantage indirectly, in accustoming the representatives of the different parts of the Empire to the views and feelings of other parts, and in cultivating the spirit of co-operation. Nor have the discussions been by any means fruitless; (efforts are being made to consolidate the company laws in the different Colonies on the model of the new Imperial Act; steps have been taken to render more uniform the mode of taking statistics of trade; legislation as to patents and trade marks has been assimilated; arrangements have been made to hold subsidiary Conferences on naturalisation and copyright, and all these matters, if small in themselves, are valuable and of promise for the future. More substantial, perhaps, has been the work done by another subsidiary Conference, that on navigation in the Australasian Colonies, which was held in 1907 just before the Imperial Conference, and at which representatives of all interests agreed on a scheme, which has in effect been carried out by the Government of the Commonwealth $(m)$.

Mention should also be made of the Conference held at Ottawa, in 1894, by invitation of the Dominion Government, and at which attended representatives from all Australasia, except Western Australia, and from the Cape. Its resolutions

(m) Parl. Papess [Cd. 3567], [Cd. 3826]. 
are of special interest, as they inaugurated the rule that no treaties must be allowed to interfere with the grant of interimperial preference, and led to the denunciation of the German and Belgian treaties, and started the conception of the Pacifie cable which eventually resulted in the laying of the cable in 1902, and the first experiment of the co-operation of the governments of the Dominions with the Imperial Government in running a large commercial venture, one which up to the present has not paid, but which has its own value as emphasising the sense of imperial unity $(n)$. A similar question, that of steamship communication, was mooted by Sir Wilfrid Laurier at the Conference of $190 \%$, and is still engaging the attention of the Imperial and Dominion Governments.

Mention may also be made of many other matters in which the sense of imperial unity is making itself felt, such as the rules for the admission of barristers and solicitors to practise in the Courts of the various parts of the Empire, the similar privileges granted to medical practitioners $(o)$, the acceptance of colonial probates in England and vice versâ $(p)$, the arrangements for mutual reductions of death duties in respect of property subject to an imperial and a colonial duty under sect. 20 of the Finance Act, 1894, and the admission of colonial government securities to the list of imperial trustee stocks $(q)$, the mutual aid given by imperial and colonial Courts in matters of bankruptcy under the Imperial Act of 1883 , and so forth. There are many imperial duties which the Colonies now share: for example, that of punishing offences committed on British ships which fall under the

(n) Ibid. [C. $7553 \mid$, [C. 7632], [C. 7824].

(o) See Professional Handbook, annually issued by Emigrants' Information Office.

(p) 85 Vict. c. 6. See L. R. [1904] P. 114.

(q) $63 \& 64$ Vict. c. 62 . 
cognisance of Colonial Courts of Admiralty under the Colonial Courts of Admiralty Act, 1890. All the cost of procedure in such cases falls on the colonial government though the service is imperial, and the Act recognises this by providing for the surrender to the colonial exchequer of the proceeds of droits of Admiralty which, under the Civil List Acts and the Merchant Shipping Act, 1894, s. 523, would otherwise belong to the Imperial Exchequer. Moreover, on every Dominion it is incumbent to see that the provisions of the Foreign Enlistment Act are carried out, and the seriousness of the obligation may be seen by the case of the "Florence," which involved the Government of Jamaica in heavy loss, of which only half was paid by the Imperial Government, as a special mark of grace in view of the poverty of the colony, and without prejudice to the obligation incumbent on the colonial government $(r)$.

(Similarly, again, the Dominions bear the burden of their defence from internal troubles, no small burden in the case of South Africa, and one which the Transvaal and the Orange River Colony can hardly be said to have fully undertaken, while recently the presence of imperial troops in Natal was of great service to the colonial government. These forces would also serve in the case of external aggression as part of the defellding forces, and in so far the Dominions contribute towards the cost of their own defence from foreign attack) These forces are indeed small. Canada has but 2,820 of all ranks in the permanent forces, and some 51,300 in the militia; Australia some 1,300 permanent forces, and 15,500 militia; and the Cape, Natal, and New Zealand have still smaller numbers. Nevertheless, the material is good, and encouragement is given to volunteering, so that the actual forces which could be obtained in time of stress are

(r) Parl. Papers [C. 3453], [C. 3523]. 
very considerable, and Australia is contemplating an increase in the numbers by adopting a system of compulsory training of the youth as cadets which is already in force in Natal. Moreover, in all the Colonies the right of the State to call on all able-bodied citizens for service in time of stress is fully recognised, and has been formally embodied in the defence laws of the Commonwealth and Natal $(s)$.

It would be premature to conjecture what shape the organisation of the Empire-will-ultimately-assume. (The immediate task of importance is the federation of South Africa, which will present serious problems, the solution of which must occupy some years. Nor can much progress be made until the Australian federation has consolidated. At present everything is still in a state of transition, and a modus vicendi between the States and the federation is ouly in a gradual state of evolution. When the South African and Australian federations are in full working order, and when Newfoundland fulfils its obvious destination and enters the Dominion, the way to further political combinations will become clearer. Such combinations must, of course, undo to some extent the isolation of the system of responsible government; but they will not alter the fact that for its time and circumstances the system was a great act of statesmanship, negative indeed in character, but essential as a preparation for closer union. Under it alone could the Dominions acquire the self-reliance and national character which will in the future enable them to enter upon a not unequal alliance or federation with the Imperial Goverument, and under it only could they have developed the great qualities of democracy which render them in so many respects an example to the United Kingdom itself. No

(s) Commonwealth Act, No. 8 of 1903 ; Natal Acts, No. 36 of 1903 ; No. 30 of 1905 . 
288 RESPONSIBLE GOVERNMENT IN THE DOMINIONS.

doubt the gain has not been without corresponding loss, and that to the freedom from the needs of self-defence is due the somewhat irresponsible spirit of Australian democracy; but that is a defect which will gradually disappear. 


\section{INDEX.}

[References are to pages: matter in brackets is supplemental to that given in the body of the Work.]

Aberdeen, Lord, views as to duty of Crown with regard to dissolution, 43.

Aberdeen, Iord, refuses to act on advice of defeated Ministry, 50 .

Absolute majorities, required for passing certain Bills, 89, 96.

Aecomplices, pardon of, 243.

Admiralty, Courts of, in Dominions (for sentences, cf. $37 \& 38$ Vict. c. 27), 214, 286.

Agent-General, position of, 80 .

Alberta, responsible government, 17 ; rests on eonstitutional practice, 19; alteration of Constitution, 91 ; privileges of Parliament, 99 ; unicameral legislature, 103 ; relation to Dominion, 145 ; representation in the Senate, 158. See Canadian Provinces.

Aliens, banishment of, 242.

Alteration of Constitution, in Dominions, 88-92.

Antigua, representative government in, 5 .

Appeals, judicial, of right and by special leave, 262-266; in the Commonwealth, 266-268; appeals in electoral cases, 268, 269 ; suggested alteration in Court, 269, 270; colonial judges in Court, 279 .

Arbitration treaty with United States, 1908...228.

Army Act, $1881 \ldots 195,196,214$.

Atkinson, Hon. Sir H., 12 j.

Bahamas, representative government in, 5 .

Balfour, Rt. Hon. A. J., originates Committee of Imperial Defence, 199.

K. 
Ballance, Hon. J., dispute with Lord Glasgow over appointments to legislative Council of New Zealand, 55, 56, 125, 126.

Banishment, 242.

Bankruptcy Act, 1883...213, 285.

Barbados, representative government in, 5 .

Basutoland, replaced under imperial control, 201, 207.

Bedford, Sir F., action in difference between Houses in Western Australia, 48, 49, 114.

Belgium, denunciation of treaty with, 233, 234, 285.

Belmore, Lord, increases New South Wales legislative Council, 122; prerogative of mercy, 238.

Bermuda, representative government in, 5 .

Berry, Hon. G., action in Victorian constitutional crisis, 111.

Bicameral legislatures, 102.

Bishops, precedence of, 246, 252, 255; appointment of, 256-258, 261. Blake, Hon. E., alteration in Royal Instructions to Canada made in deference to, 42, 240; views on power of Governor-General to disallow provincial Acts, $150-152$.

Bond, Rt. Hon. Sir R., negotiates treaty with United States, 231; does not resign in dispute with Imperial Government, 57.

Boothby, case of Judge, 276.

Bowen, Sir G., action in Victorian constitutional crisis, 110.

British Columbia, responsible government, 17 ; rests on constitutional practice, 19 ; alteration of Constitution, 91 ; privileges of Parliament, 99 ; unicameral legislature, 103 ; relation to Dominion, 145 ; representation in the Senate, 158; disputes with Federal Government, 160, 161; views of Courts on treaty questions, 223. See Canadian Provinces.

British Guiana, representative government in, 4.

British Indians, in Canada, 204; in Australia, 203; in Natal, 204, 205. Brodeur, Hon. I. P., negotiates treaty, 231.

Burke's Act (22 Geo. 3, c. 75), 277, 278.

Cabinet, relation to executive Council (cf. Jenks, Const. of Victoria, p. $267, \mathrm{n}.), 70,71$; re-election of Ministers, 71,72 ; lack of clearly defined parties, 72-74; lack of coherence in Ministries and of responsibility, 74-76; honorary Ministers, 76, 79; size of, 77, 78 ; mode of procedure (State Governors sit at formal meetings of executive Council as opposed to Cabinet meetings: information supplied by the Hon. J. W. Taverner and J. G. Jenkins), 79.

Campbell-Bannerman, Rt. Hon. Sir H., speech on defence at Colonial Conference, $1907 \ldots 282$. 
Canada, Lord Durham's report on, 6 ; responsible government, 18, 19 ; executive Council, 71, 78, 253; alteration of Constitution, 90, 91; privileges of Parliament, 99, 100 ; money Bills, 117, 118; disputes between Houses, 118-120; federation, 134-136; relation of provinces to Federal Government, 137; reservation of Bills, 180; treaty power, 231, 232, 236; prerogative of mercy, 240, 241: table of precedence, 252; judicial appeals, 266, 268; position of judges, 274 ; defence, 286.

Canadian Provinces, relation to Federation as regards (a) legislation, 136-162; (b) executive power, 152-158 ; appointment of King's counsel, 248-2.51; seals, 254 ; no instructions as to reservation, 182 ; position of judges, 274; executive Councils (Bourinot, Const. of Canada, pp. 64-72), 170.

Canterbury, Lord, refuses dissolution to Mr. Duffy, 45.

Cape of Good Hope, responsible government, 11-13; rests on constitutional practice, 20; executive Council, 71, 77, 253; alteration of Constitution, 88 ; privileges of Parliament (cf. Act No. 13 of 1883), 100 ; money Bills, 105; disputes between Houses, 115, 116; Royal Instructions as to reservation of Bills, 180, 235; position of judges, 278; naval defence, 281, 282.

Carnarvon, Lord, view as to duty of Ministers in case of disagreement with Imperial Government, $5 \mathbf{j}$; as to prerogative of mercy, 238.

Carrington, Lord, increases New South Wales legislative Council, 124

Censure on Governor (cf. British Columbia Legislative Assembly Journals, 1908, pp. 7, 21, 31), 59, 128.

Charters of incorporation, 254.

Chelmsford, Lord, declines advice of Premier to swamp legislative Council of Queensland, 49, 126-129; issues public money without Act, 62 .

Chinese, legislation as to (Parl. Papers [C. 5443]), 146, 202, 203.

Church, relation to State (cf. L. R. 7 App. Cas. 484), 256-261.

Civil liability of Governor, 33, 34.

Clerical Reserves, in Canada, 255, 256; in Australia (cf. 18 \& 19 Vict. c. 54 , s. $49 ; 18$ \& 19 Vict. c. 55 , s. 33 ; Tasmania Act, 18 Vict. No. 17, s. $31, \& c.), 256$.

Coasting trade, 192-194.

Coinage, prerogative of, not delegated to Governor, 32 ; control of Colonial legislation as to, 189, 190.

Colenso, Bishop, case of, 257.

Colonial Boundaries Act, $1895 \ldots 221$.

Colonial Conference

of $1887 \ldots 281,283$.

of $1894 \ldots 192,284,285$. 
Colonial Conference-continued.

of $1897 \ldots 233,281,283$.

of $1902 \ldots 192,269,281,283$.

of $1907 \ldots 269,281,283$.

Colonial Laws Validity Act, 1865...60, 178.

Colonial prisoners' removal, 213.

Colonial Regulations, authority of, 58.

Commercial treaties, power of Dominions with regard to, 226-228.

Committee of Imperial Defence, 199.

Commonwealth of Australia, responsible government, 24, 25 ; executive Council, 77, 253; alteration of Constitution, 91, 92 ; privileges of Parliament, 101; money Bills, 106 ; disputes between Houses, 115 ; reservation of Bills, 180, 181 ; prerogative of mercy, 241, 243; judicial appeals, 265-268; position of judges, 274, 278.

Compulsory service, in Dominions, 287.

Contempt, imprisonment for, by order of Parliament, 97.

Contempt of Court, pardon for, 242.

Continuing act, doctrine of, 85 .

Copyright, imperial control as to, 218.

Criminal liability of Governor, 35,36 .

Crown, distinction between legislative Acts and prerogative grants, $30,253,254$.

Currency, control of Imperial Government as to, 189, 190.

Customs union, in Australia (cf. the South African Union, Parl. Papers [Cd. 2977]), 191, 226; in Canada, 190.

Darling, Sir C., recall of, on grounds of illegal action, 60,61 .

Deadlocks, provision for, in Commonwealth, 91, 116; in South Australia, 112, 115 ; in Victoria, 112, 115; in Queensland, 128, 129 ; in Cape of Good Hope, 115 ; in Transvaal and Orange River Colony, 131; in New South Wales and New Zealand, 120-126.

Deakin, Hon. A., Ministry of, 48.

Deportation, power of Dominions as to, 83.

Differential duties, imperial control as to levy of, 190-192.

Dilke, Rt. Hon. Sir C., views as to dissolution in England, 43.

Dinizulu, dispute as to salary of, 57, 207.

Disallowance of Acts, 182.

Dissolution, in England, 43 ; in Colonies (cf. proposal to take away Governor's discretion, Parl. Papers [C. 5091], pp. 555 seq.), 44-50.

Divorce, imperial control as to, 187-189.

Dominions, representative government in, 5 .

Droits of Admiralty, 286. 
Duffy, Sir G., view as to Governor's power to dissolve Parliament, 44.

Duke of York (H.R.H. the Prince of Wales), precedence of, in Dominions, 247.

Durham, Lord, report on Canada, 6.

Education, Canadian legislation as to, 148, 149, 260.

Elections, no appeal to Privy Council in case of disputed, 269.

Elgin, Earl of, in Canada, 8, 248.

Exclusive powers, of Dominion Parliaments subject to imperial legislation, 86.

Executive Council, no mandamus to, lies (cf. 6 C. L. R. 40), 34; formal legal existence rests on Letters Patent in most cases, but also on British North America Act and Commouwealth Coustitution Act (cf. also Victoria Act, No. 1864, s. 5 ; New Zealand Act, No. 22 of 1908, s. 10; South Australia Act, No. 2 of 1855, 1856, 8. 32, which recognise Ministers as executive councillors), 19-26.

External affairs, in Australian Constitution, 170.

Extinction of Dominion, 94.

Extradition, 212, 213, 228.

Federal Council of Australasia, 174, 175.

Federations : (A) Canada, 134-136; relations of federation and provinces as to legislation, $136-147$; disallowance of provincial laws by Dominion, 147-152 (cf. Papua where Acts are only subject to disallowance by Governor-General); position of LieutenantGovernors, 152-158; Senate, 158, 159; appeals to Imperial Government, 159-161; (B) Australia, 162; relation of federation and provinces as to legislation, $163-168$; as to administration, 168,169 ; doubtful questions, 169-172; South Africa, 173; New Zealand, 173, 174; Federal Council of Australasia, 174, 175.

Fielding, Hon. W. S., negotiates treaty, 231.

Finance Act, $1894 \ldots 285$.

Flags, 254.

"Florence," case of, 34, 284.

Foreign affairs, imperial control of, 280-282.

Foreign Enlistment Act, 1870...286.

Foreign Powers, direct negotiations with, forbidden to Dominions, 229, 230.

Forrest, Rt. Hon. Sir J., view as to power of Commonwealth Senato as to money Bills, 106. 
"Franconia," case of the, 215.

Frere, Sir B., debate as to conduct of, 59; dispute with Ministers, 197, 198.

Fugitive Offenders Act, 1881...212, 213.

Galt, Sir A., negotiations with France and Spain, 230.

German South West Africa, 280.

Germany, denunciation of treaty with, 233, 234, 285.

Gladstone, Rt. Hon. W. E., views as to treaty prerogative, 223.

Glasgow, Lord, dispute with Ministers as to appointments to legislative Council, 55, 56, 125, 126.

Governor, form of appointment of, 28 ; nature of powers, 29, 30 ; theory of special reserve power, 31 ; limits on power, 32 ; liability to suit, $33-35$; not liable to mandamus, 36 (cf. also 6 C. L. R. 40); not on contract, 37 ; absence of, 39 ; relation to Ministers, $40-42,157$; as head of colonial government, grant of dissolution, 43-51 (cf. also Parl. Papers [C. 5091], pp. 555-558); as imperial officer, $51-58$; bound to obey directions of Secretary of State, 58 -60 ; to act according to law, 60-62, 110 ; martial law, 62-66; never appointed against wishes of Dominion, 66-68; entitled to support of Minister's, 68, 69 ; duties under Imperial Acts (cf. New Zealand Parl. Papers, 1892, A. 1, p. 7), 69; post cannot be abolished by Dominion Legislature, 95 ; powers as to precedence, \&c., 251, 254; Royal Instructions as to reservation of Bills, 175181 ; prerogative of mercy, 237-244; power to amove judges, $274-278$.

Granville, Earl, view as to issue of public money without consent of Parliament, 61; as to exercise of prerogative of mercy, 238.

Grey, Sir G., views as to Governor's power to dissolve Parliament, 45; as to the grant of titles of honour, 24.7, 248.

Hicks-Beach, Sir M., views as to duty of Governor to obey law, 61. High Commissioner. See Agent-General.

Home Rule resolutions, 184, 282.

Honourable, use of title, 253.

Hunt, Louisa, case of, in Tasmania, 55.

Immigration, legislation as to, in Canada, 146, 147; in Australia, 171, $172,201-205$.

Imperial Conference, 283. 
Imperial control of Dominion I egislature, mode of exercise (cf. Parl. Papers [Cd. 4355], pp. 7, 23), 175-184; examples of, as to (a) public lands, 185-187; (b) divorce, 187-189; (c) currency, 189,190 ; (d) differential duties, 190-192; (e) merchant shipping, $192-194$; (f) military and naval affairs, 194-201; (g) immigration, 201-205; (h) native policy, 205-208; (i) matters affecting the prerogative, $208-210$; (j) residents abroad, 210, 211. See also Copyright; Naturalization.

Imperial Council, proposal of, 284, 285.

Imperial Government, constitutional position in case of dispute of colonial government with (cf. New Zealand Parl. Papers, 1891, Sess. 2, A. 1, pp. 4, 5), 53-50.

Imperial legislation, supplements Dominion legislation, 212-221;

overrides Dominion legislation, 225.

Imperial Parliament, censures Governors, 59.

Implied powers, doctrine of, in Australia, 165, 166.

Income tax, cases in Commonwealth, 267, 268.

Indemnity Acts, 64-66.

Interpretation of treaties, rests with Imperial Government, 236.

Jamaica, representative government in, $\mathbf{4}, \overline{5}$.

Jameson, Rt. Hon. L. S., defeat in Cape Legislative Council, 11ð, 116. Japanese, legislation as to, 146, 203, 204.

Jenkins, Hon. J. G., ex-Premier of South Australia, views as to Colonial Governors in relation to Ministers, 43 ; as to relations of States and Commonwealth, 171.

Jesuits, in Quebec, 260.

Judiciary, tenure of office of, 273-279.

King, laws made in namo of, in almost all Dominions, 139 ; fountain of honour, 246.

King's counsel, 139, 248-251.

Land grants, not now made by Governor, 39.

Laurier, Rt. Hon. Sir W., defends Lord Aberdeen against attack of Sir C. Tupper, 50 ; on treaties as affecting Canada, 236; on steamship communication, 287.

Law, Governor must obey, 60-62, 109, 110. 
Legislative Councils, nominee and elective, 103, 104; powers of these Councils as to money Bills, 104-107, 117, 118; disputes with Lower Houses : in Victoria, 107-112; in South Australia, 112, 113; in Tasmania, 114 ; in Western Australia, 115 ; in the Cape, 115,116 ; in Canada, 118-120 ; in New South Wales, 120-124; in New Zealand, 12j, 126; in Queensland, 126-129; in Natal, 129, 130; in Transvaal and Orange River Colony, 131, 132; Ministers in (cf. Victoria Act, No. 1864, s. 5; South Australia Legislative Council Debutes, 1908, pp. 280 seq.), 76.

Legislatures, Dominion, not delegates of Imperial Parliament, 81 ; restrictions on legislation-(a) territorial, 82-85; (b) repugnancy to imperial law, 86; (c) repugnancy to Constitution, 87, 88; power of constitutional alteration, 88-92; other suggested limitations, 92--95; procedure, 95, 96; privileges, 96-101.

Lemieux, Hon. R., mission to Tokio, 204.

Letellier, Mr. Iuc de St. Just, dismissal of, 119, 154--157, 272.

Letters Patent, of Governors, 28; for appointment of colonial bishops, 256 ; legislating for Colonies, 258.

Lieutenant-Governors, of Canadian provinces, $152-158$; receive no instructions as to reservation of Bills (information due to $\mathrm{Mr}$. J. Pope, Under-Secretary of Canada), 182 ; no delegation of prerogative of mercy, but a statutory power, 244.

Long, case of Mr., 250, 257.

Lord-Lieutenant of Ireland, liability of, compared with that of a Governor, 33.

Lorne, Marquess of, Royal Instructions to, 41, 240.

Lyttelton, Rt. Hon. A., 282, 283.

Macdonald, Rt. Hon. Sir J., dismissal of Mr. Letellier, 154-157.

McInnes, Mr. T., dismissal of (Canada Sess. L'apers, 1900, No. 174), 156.

MacKenzie, Hon. A., 119.

Manitoba, responsible government, 17; rests on constitutional practice, 19 ; alteration of Constitution, 91 ; privileges of Parliament, 98, 99; unicameral legislature, 103; representation in the Senate, 158; disputes with Dominion, 148-150, 260. See Canadian Provinces.

Maori representation in New Zealand, 206, 208.

Marais, case of, 65.

Marriage, control of Imperial Government as to, 187, 282.

Martial law, in Natal, $\mathbf{3 6}, 57$; power of Governor as to declaring, $62-66$. 
Martin, Peter, case of, 240.

May, Sir T. Erskine, views as to Governor's power to dissolve Parliament, 47 .

Medical practitioners, 218, 219, 285.

Merchant shipping, imperial control as to, 192-194.

Merchant Shipping Act, 1894...192-194, 213, 214, 216, 217.

Mercy, prerogative of, delegated to Governor, 237, 23s ; exercised on advice of Ministers, except in some Colonies in capital cases, and in all cases where imperial interests are involved (cf. Lord Onslow's despatches, New Zealand Parl. Papers, 1891, Sess. '2, A. 1, pp. 4, 5, 19, 20 ; Hobart Mercury, Oct. 20th, 21st, 1908 ; Tasmania Act, 8 Ed. 7, No. 10 ; 6 C. L. R. 40), $238-244$.

Military forces, control of, in Dominions, 54, 194-201.

Milner, Lord, conduct of, criticised in House of Commons, 59.

Ministers, without seat in Parliament, 19 ; relation to executive Council, 19-26; relation to constituents, 26, 27 ; relation to Governor, 40-69 ; Cabinet government, $71-79$; resignation of, in disputes with Imperial Government (cf. New Zealand Parl. Papers, 1891, Sess. 2, A. 1, pp. 4, 5), 53, 55; speak in both Houses (Victoria, Act No. 1864, s. 9), 116; certain Ministers must have seats in Parliament (Victoria, Act No. 1867, ss. 5, 6 ; South Australia, Act No. 2 of 185j, 18j6, s. 32 ; Western Australia, s. 6 of Sched. to 53 \& 54 Vict. c. 26 ; Natal, Act No. 14 of 1893 , s. 9 ; Coinmonwealth, s. 64 of $63 \& 64$ Vict. c. 12 ; in all these cases, save Natal and Western Australia, the Ministers are also by law executive councillors, though they. do not constitute the executive Council; paid Ministers are also executive councillors by New Zealand Act No. 22 of 1908, s. 10 ; and cf. Transvaal and Orange River Colony Letters Patent constituting the office of Governor (s. 6), but in none of these cases are seats in Parliament necessary in law; cf. Western Australia Parl. Deb., 1908, p. 59), 19-26.

Molteno, Sir J. C., dispute with Sir B. Frere, 197, 198.

Money Bills, in Imperial Parliament, 118; in nominee legislative councils, 117, 118; in elective legislative councils, 104-107.

Natal, lesponsible government, 13-15; rests on constitutional practice, 21, 22 ; dispute with Imperial Government as to martial law, 56, 57 ; executive Council, 77 ; alteration of Constitution, 88 ; privileges of Parliament, 101 ; money Bills, 117, 118; disputes between Houses, 129, 130; Royal Instructions as to reservation of Bills, 180 ; prerogative of mercy, 239 ; position of judges, 276 ; naval defence, $281,282$. 
Native policy, imperial control as to, 205-208.

Naturalization Act (cf. Parl. Papers [Cd. 3524]), 217, 218.

Naval affairs, imperial control as to, 201 ; colonial contributions, $281,282$.

Naval Defence Act, 186j̃...214.

Navigation Bill, of Commonwealth, 193, 194, 284.

Navigation Conference, 1907...193, 194, 284.

New Brunswick, introduction of responsible government in $1848 \ldots 8$; rests on constitutional practice. 18 ; alteration of Constitution, 91 ; privileges of Parliament, 99 ; unicameral legislature, 103 ; relation to Dominion, 145 ; representation in the Senate, 158 ; education question in, $148-150,260$. See Canadian Provinces.

New South Wales, responsible government, 9 ; rests on constitutional practice, 23 ; executive Council, 78 ; alteration of Constitution, 89 ; privileges of Parliament, 98, 100 ; money Bills, 117, 118 ; disputes between Houses, 120-124; Royal Instructions as to reservation of Bills, 178,179 ; prerogative of mercy, 241; position of judges, 276 .

New Zealand, responsible government, 10 ; rests on constitutional practice, 25 ; executive Council, 77 ; alteration of Constitution, 90 ; privileges of Parliament, 101; money Bills, 117, 118 ; disputes between Houses, 125, 126; not federated with Australia, 134; once a federation, 173,174 ; reservation of Bills, 178, 181; prerogative of mercy, 239, 241 ; position of judges, 276 ; naval defence, 281, 282.

Newfoundland, introduction of responsible government in $18 \overline{5} 5 . . .9$; rests on constitutional practice, 19 ; executive Council, 76,77 ; constitutional alteration, 88; privileges of Parliament, 96, 100 ; money Bills, 117 ; disputes between Houses, 132 ; Royal Instructions as to reservation of Bills, 180, 235; sale of railway, 209; prerogative of mercy, 239, 241, 244; position of judges, 276, 278; naval defence, 282.

Normanby, Marquess of, refuses dissolution to Sir G. Grey, 45, 46; South Australia declines to receive as Governor (Dilke, Problems of Greater Britain, i, 366), 67.

Northcote, Lord, refuses dissolution to Mr. Watson and to Mr. Reid, 48 ; valedictory speeches, 43 . 
Nova Scotia, introduction of responsible government in $1848 \ldots 8$; rests on constitutional practice, 18 ; alteration of Constitution, 91 ; privileges of Parliament, 99; bicameral legislature, 103 ; dispute with Federal Government, 160. See Canadian Provinces.

Ontario, established as separate province with responsible government by British North America Act, $1867 . . .18$; alteration of Constitution, 91 ; privileges of Parliament, 98, 99 ; unicamerul legislature, 103; relation to Dominion, 145; representation in the Senate, 158 ; boundary question, 161. See Canadian Provinces.

Orange River Colony, responsible government, 16 ; rests on constitutional practice, 22 : executive Couneil, $7 \pi$; alteration of Constitution, 88; privileges of Parliament, 101 ; money Bills, 117, 118 ; disputes between Houses, 131, 132; Royal Instructions as to reservation of Bills, 179 ; prerogative of mercy, 239 ; position of judges, $\mathbf{2 7 5}$.

Pacific cable, 285.

Papua (territory under Commonwealth), 183; annexation of, 280.

Paramount chief, position of Governor as, in Transvaal and Orange River Colony, 52, 207 ; in Natal, 207.

Pardon. See Mercy.

Parkes, Sir H., views as to New South Wales Legislative Council, 123, 124 ; as to prerogative of mercy, 238.

Peualties, remission of (ef. Kenny, Criminal Law, p. 492), 243.

Petition of Right, in case of conquered colony when English law not in force, 37, 38; fiat may be granted by Crown, 38, 277.

Political treaties, relation of Dominion governments to, 228, 229, 280.

Precedence, 246-248, 251.

Preference, grant of, to United Kingdom by Dominions, 192.

Preferential right of Crown, 140.

Premiers' Conferences, 171, 175.

Prerogative of Crown, same in colonies as in England, 37, 265; reservation of Bills affecting, 208, 209. (Cf. Morcy; Precedence; Preferential Right; Coinage.)

Presentations to Governors forbidden, 58, 59, 178.

Price, Hon. T., action in deadlock in South Australia, 113.

Prime Minister, presides at Committee of Imporial Defence, 199; at Imperial Conference, 283. 
Prince Edward Island, introduction of responsible government in $1851 \ldots 8$; rests on constitutional practice, 19 ; alteration of Constitution, 91 ; privileges of Parliament, 99 ; unicameral legislature (Stat. 1893, c. 1), 103; relation to Dominion, 145 ; representation in the Senate, 158; education question, 260. See Canadian Provinces.

Privy Council, no authority over Church questions, 259; special references to, 271, 272. See Judicial Appeals.

Public lands, control of Imperial Government as to, 18j-187.

Quebec, established as separate province by British North America Act, 186i, with responsible government, 18 ; alteration of Constitution, 91 ; privileges of Parliament, 98, 99; bicameral leyislature (twenty-four members), 104; relation to Dominion, 145 ; representation in the Senate. 158; dismissal of Iieutenant-Governor, $154-157,272$; position of Church in, 255, 260. See Canadian Provinces.

Queensland, responsible government, 11; rests on constitutional practice, 23; disputes between two Houses, 49, 126-129; executive Council, 77 ; alteration of Constitution, 89 ; privileges of Parliament, 101; money Bills, 117, 118; disputes between Houses, 126-129; Royal Instructions as to reservation of Bills, $178,179,235$; prerogative of mercy (cf. New Zealand Purl. Papers, 1891, Sess. 2, A. 1, pp. 4, 5, 19, 20), 241 ; position of judges, 274.

Referendum, 89, 91, 116, 128.

Reid, Rt. Hon. G. H., refused dissolution, 48 ; refused increase of legislative Council, 124.

Representative government, disadvantages of, $2-\overline{3}$.

Reservation of Bills, under Royal Instructions, 59, 176-183; under imperial or local Acts. 179, 181, 214; of constitutional Bills, $88-90$.

Responsible government, beginnings of, 1-17; legal basis of, 18-27; unique character of, $280,287$.

Ripon, Lord, decision in dispute as to legislative Council of New Zealand, 56, 126.

Ritchie, K.C., case of Mr., 250.

Robinson, Sir H., views as to dissolution of Parliament, 47 ; as to prerogative of mercy, 238.

Rogers, Sir F., memorandum on removal of colonial judges, 277. 
Roman Catholic bishops, precedence of, 252 ; schools in Canada, 137.

Royal Instructions, 28, 40; effect of disregard of, 59, 60, 178.

Royal Mint, Dominion branches of, 189.

Royal supremacy, in Church matters, 259, 260.

Royalty, precedence of, in Dominions, 247, 248.

Salutes, 254.

Samoa, 281.

Saskatchewan, responsible government, 17 ; rests on constitutional practice, 19 ; alteration of Constitution, 91 ; privileges of Parliament, 99; unicameral legislature, 103; relation to Dominion, 145 ; representation in the Senate, 158. See Canadian Provinces.

Senate, of Canada, composition of, 158; relation to Lower House, 118 -120; of Commonwealth, 106; relation to Lower House, 106.

Shortes, case of pardon of, 241.

South African Federation, 173.

South Australia, responsible government, 10; rests on constitutional practice, 24; disputes between two Houses, 112, 113; executive Council (Act No. 2 of 1855, 1856, s. 32), 78; alteration of Constitution, 89; privileges of Parliament, 101 ; money Bills, 105 ; disputes between Houses, 112, 113 ; Royal Instructions as to reservation of Bills, $178,179,235$; prerogative of mercy, 239 ; precedence, 246, 247; position of judges, 276.

State Governors, proposed alteration in status (cf. for Western Australia, T'imes, 19 Dec. 1908), 67.

States, Australian. See Federations.

Supply, dissolution of Parliament before grant of, 46-50, 116.

Swainping of Upper House, 121-126.

Sydenham, Lord, inaugurates responsible government in Canada, 78.

Tasmania, responsible government, 10 ; rests on constitutional practice, 23; case of pardon of Louisa Hunt (contrast Hobart Mercury, Oct. 20, 21, 1908), 54; executive Council, 71, 77, 253; alteration of Constitution, 88, 89; privileges of Parliament, 101 ; money Bills, 105 ; disputos between Houses, 114 ; Royal Instructions as to reservation of Bills, 178, 179, 235; prerogative of mercy, 239 ; position of judges, $275,278$. 
Taverner, Hon. J. W., view as to dissolution of Parliament, 56.

Territorial waters, jurisdiction of Dominions restricted to, 83-86.

Territorial Waters Jurisdiction Act, 1878...215.

Tilonko, case of, 63 .

Time limit for speeches, 96.

Titles of honour, Governor has no delegation of prerogative of bestowing, 32, 60, 245; not party rewards, 248.

Transvaal, responsible government, 16; executive Council, 77; alteration of Constitution, 88; privileges of Parliament, 101; money Bills, 117, 118 ; disputes between Houses, 131, 132 ; Royal Instructions as to reservation of Bills, 179,235 ; prerogative of mercy, 239; position of judges, 275, 278.

Treaties, imperial control over, 222-226, 280 ; power to Dominions to adhere separately to, and to withdraw separately from, 226-229; negotiation of treaties for Dominions, 229-233; denunciation of treaties in interests of Dominions, 233, 234, 285; reservation of Bills affecting, 235; in Canada, 136; in Australia, 170 ; commercial treaties, 191, 192.

Tupper, Rt. Hon. Sir C., protests against Lord Aberdeen's refusal to act on his advice after defeat at general elections, 20 ; views as to issue of public money without Act, 62 ; negotiates treaty with France, 231, 232.

Unicameral legislatures, in Canadian provinces, 103.

Uniforms, 254.

Validation of Acts, by Imperial legislation, 220, 221.

Van Reenen, case of, 65 .

Victoria, responsible government, 9 ; rests on constitutional practice, 24; executive Council (Act No. 1864, s. 5), 71, 77, 253; alteration of Coustitution, 89; privileges of Parliament, 101; money Bills, 104, 105; disputes between Houses (Act No. 1864, s. 31), 106-112 ; Royal Instructions as to reservation of Bills, $178,179,235$; prerogative of mercy, 241 ; position of judges, $275,278$.

"Vondel," case of, 169-171. 
Watson, Hon. J. C., refused dissolution, 48.

Weld, F. A., refuses dissolution to Ministers, 46.

Wentworth, Mr., views on nominee councils, 123.

Western Australia, responsible government, 15, 16; rests on constitutional practice, 24 ; executive Council, 77 ; alteration of Constitution, 89 ; privileges of Parliament, 101 ; money Bills, 105 ; disputes between Houses, 114, 115; Royal Instructions as to reservation of Bills, 178,179 ; prerogative of mercy, 241 ; position of judges, 276.

Western Pacific, relations to Australia and New Zealand, 134.

Young, Sir J., action as to New South Wales legislative Council, $120,121$.

Zululand, 207. 



\section{CATALOGUE \\ NO. I386 (HOLBORH). \\ OF LAW WORKS \\ PUBISHED BY \\ STEVENS AND SONS, LTD. \\ $119 \& 120$, Chancery Lane, London.}

A Catalogue of Modern Law Works, together with a complete Chronological List of all the English, Irish, and Scotch Reports, an Alphabetical Table of Abbreriations used in reference to Lanc Reports and Text Books, Legal Remembrance Table, and Regal and Successional Table fiom 1760, and a full Index of Subjects. Demy 8 ro. (140 pp.), limp binding, post fiee. (1909.) 6d.

Acts of Parliament. - Public and Local Acts from an early date may be had of the Publishers of this Cataloyue, who have also on sale the largest collection of Private Acts, relating to Estates, Enclusures, Railuays, Rualls, \&c., \&ंc.

\section{A. B. C. (The) GUIDE TO THE PRACTICE OF THE} SUPREME COURT, I909. - Serenth Edition. By Fraxcis A. Stringer, Esq., of the Central Ottice of the Supreme Court. Roy. $12 \mathrm{mo}$.

Net, $5 s$.

** Tells the Legal Practitioner clearly and in few words hor, when and where he may take such step in procedure as he may decide to take, and defines the mode, time and place with precision.

"Of great service to the profession."-Solicitors' Journal.

ACCOUNT.-Williams' Law of Account,--Being a concise Treatise on the Right and Liability to Account, the taking of Accounts, aud Accountants' Charges. By Sydary E. Wurmass, Esq., Author of "Law relating to Legal Representatives," \&c. Demy 8vo. 1899. 10s.

"A well-arranged book, which should be very useful to receivers anc accountants generally, as well as to both branches of the legal profexsion." Lavo Journal.

ADMIRALTY.-Roscoe's Admiralty Practice,-A Treatise on the Admiralty Jurisdiction and Practice of the High Court of Justice and on the Vice-Adniralty Courts and the Cinque Ports, Se., with an $\Lambda$ ppendix containing Statutes, Rules as to Fees and Cosis, Forms, Precedents of Pleadings and of Bills of Costs. Thurd Editiou. By E. S. Roscon, Registrar, Admiralty Court, and T. Lasmbri Mrars, Esqr8., Barristers-at-Law. Demy 8vo. 1903.1 1l. 5s. "A reliable guide to the practice of the High Court in Admirsity matters." 
ADULTERATION.-Bartley's Adulteration of Food.-Statutes and Cases dealing with Coffee, Teu, Bread, Seeds, Food and Drugs, Margarine. Milk Blended Butter, Fertilisers and Feeding Stuffis, \&c., \&c. Third Editiou. By Dodolas C. Barxlexy, Esq., Barrister-at-Law. Roy. 12mo. 1907.

"Not only concise but precise."-Law Times.

ADVOCACY. - Harris' Hints on Advocacy.- Cunduct of Cases, Civil and Criminal. Classes of Witnesses and suggestious for Crossexanining them, \&c., \&c. By RICHARD HARRIs, K.C. Thirteenth Edition, with an Introduction. Royal 12mo. 1906. $78.6 d$.

"A very complete Manual of the Adrocate's art in Trial by Jury."-Sal. Jour.

"Deserves to be carefully read by the young barrister whose career is yet before him."-Law Magazine.

AFFILIATION.-Bott's Manual of the Law, and Practice in Affiliation Proceedings, with Statutes and Forms, Table of Gestation, Forms of Agreement, \&c. By W. Hornoway BotT, Solicitor. Demy 12mo. 1894.

68 .

AGRICULTURAL LAW.-Dixon,-Vide "Farm."

Spencer's Agricultural Holdings Act; 1908, with Explanatory Notes and General Forms; also the Board of Agriculture Rules and Forms, 1908, and County Court Rules and Forms, together with the Allotments and Cottage Gardens Compensation for Crops Act, 1887. Being the Fourth Edition of "Spencer's Agricultural Holdings Act, 1883." By Aubrex J. Spencer, Esq., Barrister-at-Law. Demy 8vo. Re-Issue. 1909.

"The work is concise and well arranged."-Law Times, February 6, 1909.

ALLOTMENTS. - Aggs, - Johnson, - Spencer.-Vide "Srmall Holdings."

ANCIENT WORDS.-Betts' Glossary of Ancient Words.Mostly in connection with Fines and Mrulcts. Also with Services and Tributes due to and Rights of the King, the Church, or Lords of Manors, and Privileges claimed by them. Also concerning Punishments for certain Offences and Crimes. Compiled by ArTHur Betts, Gent. Part I., letter A. 4to. 1907. Seved. Net, 10s. 6d.

ANNUAL COUNTY COURTS PRACTICE. - The Annual County Courts Practice, 1909.-By His Honour Judge SMYLY, K.C., assisted by W. J. Brooks, Esq.. Barrister-at-Law. 2 vols. Demy 8vo. (Thin paper edition in $1 \mathrm{Vol}$., price 25s.; or, on India paper, $3 s .6 d$. extra.)

1l. 58 .

"The profession generally have gratefully recognized the very great value of this book. It admirably fulfils the essential requisites of a practice book. It is complete without being discursive or of unwieldy bulk; it is accurate and easy of reference, and throughout bears the stamp of having been compiled by a man who is thoronghly acquainted with his subject."-Law Times.

ANNUAL DIGEST.-Mews'.-Vide "Digest."

ANNUAL LIBRARY, THE LAWYER'S:-

(1) The Annual Practice,-Snow, Burner, and Strinokr.

(2) The A. B. C. Guide to the Practice.-STrinaer.

(3) The Annual Digest.-Mrws. (Also issued Quarterly.)

(4) The Annual Statutes.-Hanburr Aags.

(5) The Annual County Court Practice,-Smrry.

(6) The Magistrate's General Practice.-Atkinson.

Annual Subscriptions. (a) For Complete Series, as above, delivered on the day of publication, net, 2l. $18 s$. (b) Nos. 1, 2, 3, 4, and 6 only, net, 2l. 8s. (c) Nos. 3, 4, 5, and 6 only, net, 2l. 5s. (If A. B. C. Guids is not uanted $2 s .6 d$. may be deducted for subscription to Series $(a)$ or $(b)$. If Magistrate's Practice is not wanted 10s. may be deducted from any series. (Carriage extra, 2s.)

* All standard Law Workr are kept in Stuck, in law calf and other bindings. 
ANNUAL PRACTICE.-The Annual Practice. 1909. Edited by T. Snow, Barrister-at-Law ; C. Burnzy, a Master of the Supreme Court: and F. A. Stringkr, of the Central Office. ? vols. 8vo. (Thin paper edition in $1 \mathrm{Vol}$., price 25. net; on India paper, $3 s .6 d$. extra.)

Net, 11.58 .

"A book which every practising English lawyer must have."-Law Quarterly. "Every member of the bar, in practice, and every London solicitor, at all events, tinds the last edition of the Annual Practice a necessity."-Solicitors' Journal.

ANNUAL STATUTES._- Vide "Statutes."

ARBITRATION.-Russell's Treatise on the Power and Duty of an Arbitrator, and the Law of Submissions and Awards; with an Appendix of Forms, and of the Statutes relating to Arbitration. Ninth Edition. By Edward Pollock, Esq., an Oficial Referee of the supreme Court of Judicature, and HAROLD WARREN Pollock, Esq., Barrister-at-Law. Royal kvo. $1906 . \quad 16.10 s$.

"Every matter likely to arise is here dealt with, and the book deservedly maintrins its position as the leading authority on urbitration."-Ln:4 Times.

"After a careful examination of the wav in which the work has been done, we may say that nothing which the practitioner will want to know seems to have been omitted." - L vw, Journal.

ARGENTINE REPUBLIC, Code of Commerce.Translated by G. Wilson-Raz and Bervardo de Speluzzi. Demy 8vo. 1904 .

Net, 16 .

AUCTIONEERS. - Hart's Law relating to Auctioneers, House Agents and Valuers, and to Commission.-By НевEB НART, E\&]., LL.D., Barrister-at-Luw. Second Edition. Demy 8vo. 1903. 15.'

"Revommended not only to lawyers, but also to auctioneers and property agents who wish to inform themelves as to their legal pusition." - Law Journal.

AVERAGE. - Arnould. - Vide "Insurance."

Hopkins' Hand-Book of Average,-Fourth Elition. By Mavtey Hopzins, Esq. Demy 8vo. 1844.

Il. 18.

Lowndes' Law of General Average.-English and Foreign. Fourth Edition. By Rrchard Lowndes, Average Adjuster, Author of "The Law of Marine Insurance," \&c. Royal xvo. 1n85. 16. 108.

BANKING. - Hart's Law of Banking. - Secour Eidition. With an Appendix on the Law of Sto $k$ Exchange Transactions. By Heвer Hart, Esq., LL.D., Barrister-at-Law. Royal 8vo. 1906. "l. 10s.

"Well arranged and cleurly written, and its value is enhanced by an excellent index .... of great use both to the lawyer and to the banker." - Linc Journal.

"The book is characterised st once by ctearness and fulness. . . . very useful in all mutters affecting banks and their customers." - Solicitnrs" Jnurnal.

"The most comprehensive and most complete ever published on the Inw of Banking." -Bank Notes.

"The best all-round work on banking law which is in existence . . . excellently written, and the arrangennent of the various divisions of the work is excellent also."-Financial News.

Walker's Treatise on Banking Law.-Second Edition. By J. D. W ALKEB, Esq., K.C. Derny 8vo. 1885.

BANKRUPTCY. - Lawrance's Precedents of Deeds of Ar. rangement between Debtors and their Creditors; including Forms, with Introductory Chapters, also the Deeds of Arraugement Acts, 1887 and 1890, with Notes. Fifth Edition. By Artuur LawRlavce, Esq., Barrister-at-Law. Demy 8vo. 1900.

"Concise, practical, and reliable."-Law Times.

Pellerin.-Vide "French Law."

Williams' Law and Practice in Bankruptcy.-Compriming the Bankruptcy Acts, is83 to 1890, the Baukruptcy Rules and Forme, sc. By the Riyht Hon. Sir Roland L. Vaubhan Wrulams, a Lord Justice of Appeal. Ninth Edition. By Edward Wr. Hassell. assisted by A. Roskr Mackin, Esqra., Barristers-at-Law. Royal 8 vo. 1903 .

"The leading text-book on bankruptcy." - Law Journab.

$\because$ All standard Law W'urks ure kept in Sluck, in law calf und other bindings. 
BILLS OF EXCHANGE.-Chalmers' Digest of the Law of Bills of Exchange, Promissory Notes, Cheques and Negotiable Securities. Seventh Edition. By Sir M. D. Cratmers, K.C.B., C. S. I., Draughtsman of the Bills of Exchange Acts. Demy 8vo. 1909.

"The leading book on bills of exchange."-Law Journal.

BILLS OF. LADING.-Pollock's Bill of Lading Exceptions.By Henry E. Pollock. Second Edition. Demy 8vo. 1896. 108.6d.

BORROWERS.-Alabaster.-Fide " Money-Lenders."

BUILDING SOCIETIES.-Wurtzburg on Building Societies. - The Law relating to Building Societies, with Appendices containing the Statutes, Regulations, Act of Sederunt, Forms of Annual Account and Stutement, and Precedents of Rules and Assurances. Fourth Edit. By E. A. Wurtzburo; Esq., Barrister-at-Law. Demy 8vo. 1902. 168.

CARRIERS.-Carver's Treatise on the Law relating to the Carriage of Goods by Sea.-Fifth Edition. By R. A. WRIGHT, Esq., Barrister-at-Law. Royal 8 vo.

"The standard modern book on Carriage by Sea."-Law Journal.

"An able and practical statement of an extremely important branch of the law."-Solicitors' Journal.

"Stands in the first rank of Text-books."-Law Quarterly Review.

Disney's Law of Carriage by Railway.-Second Edition. By Hex RY W. Disney, Esq., Barrister-at-Law. 8vo. 1909. 7s. 6d.

"Will be found a real assistance to any person suddenly confronted with a knotty question on the carriage of goods or of persons . . can be cordially recommended to the lawver." - Law Times

Macnamara's Law of Carriers of Merchandise and Passengers by Land.-Second Edition. By Watter Henry Macnamara, Esq., a Master of the Supreme Court, Registrar to the Railway Commission, and W. A. Rosertson, Esq., Barrister-at-Law. Royal 8vo. 1908. 1l. $10 s$.

"Should find a place in the library of all railway men. The work is written in a terse, clear style, and is well arranged for speedy reference."-Railway News. "A complete epitome of the law relating to carriers of every class."-Railway Press.

Sieveking's German Law Relating to the Carriage of Goods by Sea.-By Dr. Alfred Sieveking, of Hamburg. Demy 8vo. 1907. 15s. "A very thorough piece of work."-Law Times.

CHANCERY, and Vide " Equity."

Daniell's Chancery Practice.-The Practice of the Chancery Division of the High Court of Justice and on appeal therefrom. Seventh Edition, with references to the companion volume of Forms. By Cecil C. M. Dale, Charles W. Greenwood, Sydnex E. Wilmums, Esqr8., Barristers-at-Law, and Francis A. Stringre, Esq., of the Central Office. 2 vols. Royal 8vo. 1901. $5 l .5 s$.

Daniell's Forms and Precedents of Proceedings in the Chancery Division of the High Court of Justice and on Appeal there. from. Fifth Edition, with summaries of the Rules of the Supreme Court: Practical Notes; and references to the Seventh Edition of Daniell's Chancery Practice. By Chardes Burner, Esq., a Master of the Supreme Court. Royal 8vo. $1901 . \quad 2 l .10 s$.

“ With Daniell the practitioner is 'personally conducted,' and there are very few lawyers who will not be grateful for such guidance, carried out as it is by the collaboration of the most competent hands."-Law Journal.

CHILDREN.-Hall's Children Act, 1908.- Being a Third Edition of the Law Relating to Childreu, containing the complete Text of the Children Act, 1908, and other Statutes relating to Children, with Notes and Forms. By W. Crarkr Hall aud Arsold H. F. Prettry, Esqrs., Barristers-at-Law. Demy 8vo. 1909.

** All standard Lato Works are kept in Stock, in law calf and other bindings. 
CIVIL CODE.-See also "French Law."

Wang's German Civil Code.-Translated and Annotated, with an Historical Introduction and Appendices By Chung HuI Wavo, D.C.L., Esq. Royal 8vo. 1907.

"We can confidently recommend this work as a most valuable accession to the library of every lawyer " hos ? practi e brings him into touch with Germany."
-Law Times.

CIVIL ENGINEERS.-Macassey and Strahan's Law relating to Civil Engineers, Architects and Contractors.-With a Chapter on Arbitrations. Second Edition. By L. Lrvinaston Macassery and J. A. Straran, Esqre., Barristers-at-Law. Demy 8vo. 1897. 12s. 6d.

CIVIL LAW.-Schuster on the Principles of German Civil Law.-By Ernfst J. Schuster, Esq., Barrister-at-Law. Demy 8 vo. 1907.

Net, 12s, 6d.

COAL.-Cockburn's Law of Coal, Coal Mining, and the Coal Trade, and of the Holding, Working, and Trading with Minerals gonerally. - By JoHn Henry Cockburs, Solicitor. Royal 8vo. 1902.

16. 168 . "A book in which the whole law of mines and minerals is discussed fully and with considerable ability."-Law Journal.

COLLIERIES: (Management and Rating of).Hans Hamilton and Forbes.-Vide "Rates and Rating."

COLLISIONS.-Marsden's Treatise on the Law of Collisions at Sea.-Fifth Edition. By Rzornatd G. Marsden, Esq., Barristerat-Law. Royal 8vo. 1904.

1l. 108 .

COLONIAL AND FOREIGN LAW.-Burge's Commentaries on Colonial and Foreign Laws Generally and in their Conflict with each other,-New and Enlarged Edition, By A. Wood Renton, Esq., Puisne Judge, Ceylon, and G. G. Punlmore, Esq., Barrister-at-Law, assisted by Experts in the several systems of Law. 5 vols. Royal 8vo. (Vols. I. \&II., 1907-8, now ready.) Net, 8l. 8s.

** Full Prospectus on application.

-The whole work shows on every page the greatest care and excellent editing, and bids fair to be not only an important contribution to our legal licerature, but, in the b-st sunse of the word, an Imperial asset "- Latu Journal, Dec. 26th, 1901 .

Burge's Colonial Laws and Courts.-With a sketch of the Legal Systems of the World and Tables of Conditions of Appeal to the Privy Council. Edited by A. Woon Renton, Esq., Puisne Judge, Ceylon, and G. G. Phillimork, Esq., Barrister-at-Law. Royal 87o. 1907.

Keith. - Vide "Constitutional Law."

Net, $15 s$.

COMMISSION. - Hart.-Vide "Auctioneers."

COMMON LAW. -Chitty's Forms.-Vide " Forms."

Pollock's Expansion of the Common Law.-By Sir Fredr. Pollock, Bart., D.C.L., Barrister-at-Law. Demy 8vo. 1904. $6 s$.

"The lectures treat of the progress of the common law from early times with an eloquence and a wealth of illustration which ulone would make them fascinating reading for the student of law or history." - Law Journal.

Shirley.-Fide "Leading Cases."

Smith's Manual of Common Law. - For Practitioners and Studenta. Comprising the Fundamental Principles, with aseful Practical Rules and Decisions. Twelfth Edition. By C. Spurnino, Erq., Barristerat-Law. Demy 8ro. 1905. 15 s.

"The student might use this work as a first book with considerable advantage." - Law Students' Journal.

** All standard Law Works are kept in Stock, in law ealf and other bindings. 
COMPANY LAW.-Astbury's Guide to the Companies (Consolidation) Act, 1908.-With full explanatory Notes of all Cases reported since 1900 , and of the Statutory provisions introduced by the Acts of 1900 and 1907. By C. J. AstBuRY, Esq., Barristerat-Law. Royal 8vo. 1909.

Goirand.-Vide "French Law"

Palmer's Companies Act, 1907, and Limited Partnerships Act, 1907, with Explanatory Notes, Rules and Forms. Second Edition. By Sir Francis Beaufort PaLmer, Bencher of the Inner Temple. Royal 8ro. 1908.

7s. $6 d$.

"The skill of the master-hand is conspicuons on every page." -Lnw Times.

"A master of the subject, who writes for lawyers."-Saturday Review.

"Criticism must be silent before Sir Francis Palmer's works on company law. He is the acknowledged master of the subject."-Low Journal.

"Certain to find its way to the booksbelf of every lawyer who prides himself upon doing company work intelligently and well."-Financial News.

"What better interpreter could we have than Sir F. B. Palmer, with his experience of every phase of company law."-Law Quarterly Review.

Palmer's Company Law.-A Practical Handbook for Lawyers and Business Men. With an Appendix containing the Companies (Consolidation) Act, 1908, and Rules. Sixth Edition. By Sir Francis Beaufort Patmer, Bencher of the Inner Temple. Royal 8vo. 1909.

12s. $6 d$.

"For the purposes of the ordinary lawyer or business man there is no book on this very complex subject which we can more confidently recommend."Law Journal.

"Whatever Mr. Palmer says on Company Law comes stamped with an authority which few would dare dispute."-Law Notes.

"Palmer's 'Company $\mathrm{Law}$ ' is one of the most useful and convenient textbooks on the practitioner's bookshelf."-Law Times.

"Perhaps what practising lawyers and business men will value most is the precious quality of practicality." - Law Quarterly Review.

\section{Palmer's Company Precedents.-}

\section{Part I. GENERAL FORMS.}

Promoters, Prospectuses, Underwriting, Agreements, Memoranda and Articles of Association, Private Companies, Employés' Benefits, Resolutions, Notices, Certificates, Powers of Attorney, Banking and Advance Securities, Petitions, Writs, Pleadings, Judgments and Orders, Reconstruction, Amalgamation, Special Acts. With Copious Notes and an Appendix containing the Acts and Rules. Ninth Edition, with Revised Table A. By Sir Francis Beaufort Palmer, Bencher of the Inner Temple, assisted by the Hon. C. Macnaghten, K.C., and Frank Evans, Esq., Barrister-at-Law. Roy. 8vo. 1906. 1l. $16 s$. ** The Revised Table A., with Notes and Supplementary Forms, separate, Net, $1 s .6 d$.

" Despite his many competitors, Mr. Palmer

"Holds solely sovereign sway and masterdom." -Law Quarterly Review.

"No company lawyer can afford to be without it."-Law Jourual.

Part II. WINDING-UP FORMS AND PRACTICE.

Compulsory Winding-Up, Voluntary Winding-Up, Winding-Up under Supervision, Arrangements and Compromises, with Copious Notes, and an Appendix of Acts and Rules. Tenth Edition. By Sir Francis Beaufort Palmer, Bencher of the Inner Temple. Royal 8vo.

(In preparation.)

Part III. DEBENTORES AND DEBENTURE STOCK.

Debentures, Trust Deeds, Stock Certificates, Resolutions, Prospectuses, Writs, Pleadings, Judgments, Orders, Receiverships, Notices, Miscellaneous. With Copious Notes. Tenth Edition. By Sir Francrs Beadfort Palmer, Bencher of the Inner Temple. Royal 8vo. 1907.

"The result of much careful study. . . . . Simply invaluable to debentureholders and to the legal advisers of such investors."-Financial News.

${ }_{*}^{*}$ * All standard Law Works are kept in Stock, in law calf and other bindings. 
COMPANY LAW-continued.

Palmer's Private Companies, their Formation and Advantages; being a Concise Popular Statement of the Mode of Converting a Business into a Private Company, with Notes on Limited Partnerships. Twenty-second Edition. By Sir F. B. PALMrr, Bencher of the Inner Temple. 12mo. 1908.

Net, 1..

Palmer's Shareholders, Directors, and Voluntary Liquidators' Legal Companion.-A Manual of Every-day Law and Practice for Promoters, Shareholders, Directors, Secretaries, Creditors, Solicitors, and Voluntary Liquidators of Companies under the Companies (Consolidation) Act. 1908, with Appendix of useful Forms. Twenty-fifth Edit. By Sir F. B. Palmse, Bencher of the Inner Temple. 12mo. 1909.

vet, 2 s, $6 d$.

COMPENSATION.-Cripps' Treatise on the Principles of the Law of Compensation. By C. A. Cripps. Fisq.. K.C. Fifth Edition. By the Author, assisted by A. T. LAwrexce, Hiq., Barrister-at-Law. Royal 8vo. 1905. Il. 6s. "A clear and practicul exposition of this brinch of the law."-Solicitors" Journal. "There are few men whnse practical knowledge of the subject exceeds that of the liarned author."-Lnw Quartorly Review.

COMPOSITION DEEDS.-Lawrance,_Tide "Bankruptcy." CONDITIONS OF SALE.-Farrer.-Vide "Vendors \& Purchasers."

Webster.-Vide "Vendors and Purchasers."

CONFLICT OF LAWS.-Dicey's Digest of the Law of England with reference to the Conflict of Laws. Second Edition. By A. V. Dicer, Esq., K.C., Hon. D.C.L. Roy. 8vo. 1908. 1l. $10 \mathrm{~s}$. "Indispensable to anyone having much to do with questions of so-called Private International Law."-Law Quarterly Review, Jan. 1909.

"The most authoritutive statement of private international law in England." -Layn Times. Jan. 23rd, 1909

CONSTITUTION. - Anson's Law and Custom of the Constitution. Third Edition. Bv Sir W. R. Asson, Bart., Barrister-at-Law. Demv 8ro. Vol. II. Part I. The Crown. 1907. Net. 10s.6d.

CONSTITUTIONAL HISTORY. - Maitland's Constitutional History of England. By F. W. Martuand, Eqq., LL.D. Demy 8vo. 1908.

CONSTITUTIONAL LAW. - Keith's Re'ponsible Government in the Dominions. - By A rtiur Brrriedale K Fitr, E*... Barrister-at-Law, and of the Colenial Office. Demy sro. 1909. 10s.

"This bool, though only some 300 pages in length, is a most workmanlike account of the constitutions of most of the over-sea dominions." - Solicitors" Jourua'. Marelı 20, 1909.

Keith's Theory of State Succession, with special reference to Euglish and Colonial Law. By ArtuUr Berriedat. Keitr. Eaq.. B irrister-at-Law, and of the Colonial Office. Roy. 8 vo. 1907. Kit, 6s.

Ridges' Constitutional Law of England.-By E. Wavell Rinors, Eiq., Barrister-at. Law. Demy 8vo. 1905. 128.6d. ". We think this brok will be found a very useful compendium of con. stitutional law. The more especially as it ensbles the student to obtain a completer view of the whole fleld than is obtainable from any complet book with which we are acquainted."-Ian Nobs.

"Mr. Ridges has produced a book which will rark high as a practical gride on matters constitutional and political . . the bosk is an able and practical contribution to the study of constitutional law." - Solicitors' Jourwat.

CONTRACT OF SALE.-Blackburn.-Tide "Sales."

CONTRACTS.--Addison on Contracts. - A Treative on the Law

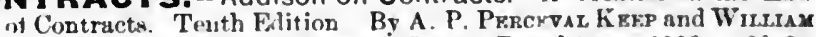
E. Gordon. Esirss., Barristern-at-Law. Royal 8ro. 1903. 2l. 28.

"Eswentially "h, prisctitioner's text-book."-Law Jowrnal.

"Among all the works on Contracts, there is none more nefnl to the practitioner than Addison." - Lnu Times.

$\because$ All standard Law Works are kept in Stock, in lawe calf and other bindings. 
CONTRACTS-continued.

Anson's Principles of the English Law of Contract.-By Sir W.R. Asson, Bart., Barrister-at-Law. Eleventh Edit. 1906. 10s.6d. Fry.-Vide "Specific Performance."

Leake's Law of Contracts,-Principles of the Law of Contracts. By the late S. Martin Leake. Fifth Edition. By A. E. Randanu, Esq., Barrister-at-Law. Royal 8vo. 1906. 1l. 12s.

"The high standard attained in the former issues has been well sustained. and the work carefully revised and brought well up to date."-Law Times.

"A full and reliable guide to the principles of the English Law of Contract," -Law Journal.

"Admirably suited to serve the purpose of the practitioner .... the work is complete, accurate, and easy of reference."-Solicitors' Journal.

Pollock's Principles of Contract.-A Treatise on the General Principles concerning the Validity of Agreements in the Law of England. Seventh Edition. By Sir Freprrick Pounock, Bart., Barrister-at-Law, Author of "The Law of Torts," "Digest of the Law of Partnership," \&c. Demy 8vo. 1902. 1 . 8s.

"A work which, in our opinion, shows great ability, a discerning intellect, a comprehensive mind, and painstaking industry."-Law Journal.

CONVEYANCING. - Brickdale \& Sheldon. - Vide "Land Transfer."

Dickins' Precedents of General Requisitions on Title, with Explanatory Notes and Observations. Second Edition. By HerBerst A. Dickins, Esq., Solicitor. Royal 12mo. $1898 . \quad 58$.

Farrer,-Vide "Vendors and Purchasers."

Greenwood's Manual of the Practice of Conveyancing. To which are added Concise Common Forms in Conveyancing.-Ninth Edition. Edited by Harry Grkenwood, M.A., LL.D., Esq., Barrister-at-Law. Roy. 8vo. 1897.

Hogg's Precedents of Conveyancing Documents for Use in Transactions Relating to Registered Land under the Land Transfer Acts, 1875 \& 1897.- With Notes. By J AMES EDWARD HogG, Esq., Barrister-at-Law. Royal 8vo. $1907 . \quad 12 s .6 d$.

Hood and Challis' Conveyancing, Settled Land, and Trustee Acts, and other recent Acts affecting Conveyancing. With Commentaries. Seventh Edition. By Percy F. WheELer, assisted by J. I. Smrinna; Esqrs., Barristers-at-Law. Royal 8vo. 1909. (Nearly ready.) 20s.

"This is the best collection of conveyancing statutes with which we are acquainted. . . The excellence of the commentaries which form part of this book is so well known that it needs no recommendation from us."-Law Journal.

Jackson and Gosset's Precedents of Purchase and Mortgage Deeds.-By W. Howland Jackson and Thorold Gosset, Esqrs., Barristers-at-Law. Demy 8vo. 1899.

Prideaux's Precedents in Conveyancing-With Dissertations on its Law and Practice. 19th Edition. By Jors Whrtcomers and Brijamt Lennard Cherex, Esqrs., Barristers-at-Law. 2 vols. Royal 8vo. 1904.

$$
\text { *** A new Edition is in preparation. }
$$

3l. 10s.

"“Prideaux' is the best work on Conveyancing."-Law Journal.

"Accurate, concise, clear, and comprehensive in scope, and we know of no treatise upon Conveyancing which is so generally useful to the practitioner." Law Times.

"The dissertations will retain their time-honoured reputation."-Law Journal.

Strachan's Practical Conveyancing. By Walter Strachan, Esq., Barrister-at-Law. Royal 12mo. 1901. 8s. 6d.

Webster.-Vide "Vendors and Purchasers."

Wolstenholme,-Vide "Forms."

*** All standard Law Works are kept in Stock, in law calf and other bindings. 
CORONERS.-Jervis on Coroners, - With Forms and Precedents. Sixth Edition. By R. E. Mrushrnckr, Esq., Barrister-at-Law. Post 8vo. 1898.

10s. $6 d$.

COSTS.-Johnson's Bills of Costs.-By Horace Maxwel JoHNson, Esq., Barrister-at-Law. Second Edition. 1901. 16. 158.

Webster's Parliamentary Costs.-Private Bills, Election Petitions, Appeals, House of Lords. Fourth Edition. By C. CavaraGr, Esq., Barrister-at-Law. Post 8vo. 1881.

COUNTY COURTS.-The Annual County Courts Practice, 1909. By His Honour Judge Smrry, K.C., assisted by W. J.' Brooks, Esq., Barrister-at-Law. 2 vols. Demy 8vo. 1l. 5 s.

* Thin paper edition in $1 \mathrm{Vol}$., price 25s.; or, on India paper, $3 s .6 d$. extra.

"Invaluable to the County Court practitioner."-Law Journal.

"The practitioner can still resort to the work with confidence that all that care and labour can do to aid him bas been done."-Laro Yagazine, Feb., 1909.

COVENANTS.-Hamilton's Concise Treatise on the Law of Covenants,-Second Edition. By G. BALDwIN Hummion, Esq., Barrister-at-Law. Demy 8vo. 1904. 10s. 6d.

"We welcome the second edition of a very useful book."-Law Journal.

COVENANTS AFFECTING LAND.-Jolly's Restrictive Covenants affecting Land.-By W. ARsold JoLLY, Esq., Barrister-at-Law. Demy 8vo. 1909.

"We have no doubt that this rolume will prove of great assistance in dealing with the numerous questions which arise in connection with building schemes and restrictive covenants affecting land."-Lavo Times, Jarch 27, 1909.

CRIMINAL LAW.-Archbold's Pleading, Evidence and Practice in Criminal Cases.-With the Statutes, Precedents of Indictments, \&c. Twenty-third Edition. By Wrumx F. Cranks and Gur Strepreavson, Esqrs., Barristers-at-Law. Demy 8vo. 1905. 1l. 15s.

"This book is quite indispensuble to everyone engaged in the practice of the Criminal Law."-Solicitors' Journal.

Bowen-Rowlands on Criminal Proceedings on Indictment and Information (in England and Wales).-By E. BowEN-Rowlayss, Esq., Barrister-at-Law. Demy 8vo. 1904. 12s. 6d. "An invaluable source of information and a safe guide."-Pall Mall Gazette.

Chitty's Collection of Statutes relating to Criminal Law.-(Reprinted from "Chitty's Statutes.") With an Introduction and Index. By W. F. Crutrs, Esq., Barrister-at-Law. Royal 8vo. $1894.10 s$.

Disney and Gundry's Criminal Law.-A Sketch of its Principles and Practice. By HeNey W. Dissexy and Harowd Gundry, Esqrs., Barristers-at-Law. Demy 8vo. 1895. 7s.6d.

Kenny's Outlines of Criminal Law. 3rd Ed. Demy 8vo. 1907. 1Cs.

Kenny's Selection of Cases Illustrative of English Criminal Law.-Second Edition. Demy 8vo. 1907.

12s. $6 d$.

Kershaw's Brief Aids to Criminal Law.-With Notes on the Procedure and Evidence. By Hutos Krrshaw, Esq., Barrister-atLaw. Royal $12 \mathrm{mo} .1897$.

$3 s$.

Roscoe's Digest of the Law of Evidence and the Practice in Criminal Cases (chiefly on Indictment).-Thirteenth Edition. By Hervas Cormes, Esq., Barrister-at-Law. 1908. 11. 11s. 6d. "There is no better book for the every-day use of the practitioner in the criminal courts than Roscoe."-Solicitors' Journal.

"Ought to be in the possession of every practitioner in the criminal courts." - Laro Times, May 16, 1908.

"Of great use to practitioners."-Lav Journal.

Russell's Treatise on Crimes and Misdemeanors.-Sixth Edit. By Horact Sxrm, Esq., Metropolitan Police Magistrate, and A. P. Percetal Krep, Esq. 3 vols. Roy. 8vo. $1896 . \quad$ 5l. 15s.6d. * A new Edition is in the press.

Warburton.-Vide "Ieading Cases."

* All standard Lawo Works are kept in Stock, in law calf and other bindings. 
CROWN PRACTICE.-Robertson on the Crown.-The Law and Practice of Civil Proceedings by and against the Crown and Departments of the Government. With numerous Forms and Precedents. By G. Stuart Robertson, Esq., Barrister-at-Law. Royal 8vo. 1908.

1l. 18 .

"Will be of great service to the Profession."-Law Times.

"The book is likely to take a high place as a book of practice." - Solicitors' Journal.

"Iawyers and students of legal history owe more than ordinary thanks to Mr. Robertson for this work. It is one of those exceptional books which after use will be laid down with the question, Where did people go before it was published?"-_aturday Review.

CUSTOM AND THE USAGES OF TRADE.-Aske's Law relating to Custom and the Usages of Trade.-By RoBrRT WILLIAM Aske, Esq., LL.D. (Lond.), Gold Medallist in Laws of the University of London. Demy 8vo. 1909.

I6s.

CUSTOMS. - Highmore's Customs Laws. Second Edition. By Sir Nathaniel J. Hrohmore, Barrister-at-Law, Solicitor for His Majesty's Customs. Demy 8vo. 1907.

DEATH DUTIES.-Freeth's Acts relating to the Estate Duty and other Death Duties, including the Finance Act, 1907, with an Appendix containing the Rules Regulating Proceedings in England, Scotland and Ireland in Appeals under the Acts and a List of the Estate Duty Forms, with copies of some which are only issued on Special Application. Fourth Edition. By Sir Everyn Freirtr, Secretary of the Estate Duty Office, assisted by CHARLES ROBERT Euлотт, Esq., of the Estate Duty Office.' Demy 8vo. 1908. 12s.6d.

"The official position of the Author renders his opinion on questions of procedure of great value."-Solicitors' Journal.

"Sir Evelyn Freeth is the Secretary of the Estate Duty Office, and Mr. Elliott is a colleague in the same office. In preparing a book such as this on the Estate and Death Duties their official familiarity with all the rules and modes of procedure gives them advantages which can hardly be rivalled by the outside legal author, however skilled he may be in the principles and case law of the subject. Solicitors have every day asked for the assistance of such a book, and nowhere can they obtain it more certainly than in the practical pages of this book.-Saturday Review.

Harman's Finance Act, 1894, and the Acts amending the same so far as they relate to the Death Duties, and more especially to Estate Duty and Settlement Estate Duty. With an Introduction and Notes, and an Appendix. By J. E. Harmas, Esq., Barrister-at-Law. Second Edition. Roy. 12mo. 1903.

DEBENTURES AND DEBENTURE STOCK.-Palmer. -Vide "Company Law."

DEBT RECOVERY,-Impey's Debt Recovery and County Court Procedure.-A Practical and Easy Guide for Business Men. By Harry Impey, Esq., a Bailiff of the Luton County Court. Demy 12mo. 1908.

Net 18 .

DECISIONS OF SIR GEORGE JESSEL.-Peter's Analysis and Digest of the Decisions of Sir George Jessel ; with Notes, \&c. By A Pstery Prere Prter, Solicitor. Demy 8vo. 1883. $16 s$.

DEEDS REGISTRATION.-Hogg's Deeds Registration.A Treatise on the Law of Registration of Documents affecting Land under the Registration of Deeds Acts of Australasia. By JАMrs Edward Hoga, Esq., Barrister-at-Law. Demy 8vo. 1908. 12s. 6d.

** All standard Law Works are kept in Slock, in law calf and other bindings. 
DIARY.-Lawyer's Companion (The) and Diary, and London and Provincial Law Directory for 1909.-For the nes of the Legal Profession, Public Companies, Justices, Merchants, Estate Agents, Anctioneers, \&c., \&c. Edited by Eowrs Luruas, Esq., Barrister-atLaw ; and contains Tables of Costs in the High Court of Judicature and County Court, \&c.; Monthly Diary of County, Local Government, and Parish Business; Oaths in Supreme Court; Summary of Statutes of 1908; Alphabetical Index to the Practical Statutes since 1820; Schedule of Stamp Duties; Legal Time, Interest, Disconnt, Income, Wages and other Tables; the New Death Duties; and a variety of matters of practical ntility : together with a complete List of the English Bar, and London and Country Solicitors, with date of admission and appointments. Publisherd ANronicy. Sixty-third Issue.

Issued in the following formb, octavo size, strongly bound in cloth :-

1. Two days on a page, plain . . . . . . . 5s.0d.

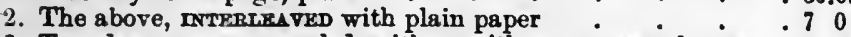

3. Two days on a page, ruled, with or without money columns 56

4. The above, with money columns, ITTkRLRA ved with plain parer 80

5. Whole page for each day, plain . . . . . . 76

6. The above, INTERLEAVRD with plain paper $\quad$. $\quad . \quad$. $\quad .96$

7. Whole page for each day, ruled, with or without money columns 86

8. The above, INTRRLKavkd with plain paper . . . 106

9. Three days on a page, ruled blue lines, without money columns. 36

10. Whole page for each day, plain, without Directory . . 30

The Diary conrains memoranda of Legal Business throughout the Year, with an Index for ready reference.

"The legal Whitaker."-Saturday Review.

"The amount of information packed within the covers of this well-known book of reference is almost incredible. In addition to the Diary, it contains nearly 800 pages of closely printed matter, none of which could be omitted without, perhaps, detracting from the usefulness of the book. The publishers seem to have made it their aim to include in the Companion every item of information which the most exacting lawyer could reasonably expect to find in its pages, and it may safely be said that no practising solicitor, who has experienced the luxury of having it at his elbow, will ever be likely to try to do without it." -Law Journal.

DICTIONARY.-Stroud's Judicial Dictionary of Words and Phrases Judicially Interpreted. To which has been added Statutory Definitions. - Second Edition, with Supplement to end of 1906. By F. Stroud, Esq., Barrister-at-Law. 4 vols. Roy. 8vo. $1903-1909$. 4l. 48.

* * The supplemental Volume, bringing the work down to 1906, may be had separately. 1 l. 18 .

"The work is anique, and indispensable to every practitioner."Law Times.

"Must find a place in every law library. It is difficult to exaggerate its usefulness. ... is invaluable, not only as a labour-8aving machine, but as a real contribution to legal literature. . . . a standard classic of the law."-Law Journal.

"This judicial dictionary is pre-eminently a ground from which may be extracted suggestions of the greatest utility, not merely for the adrocate in court, but also for the practitioner who has to advise." - Solicilors' Journal.

"A book which every practising lawyer should have in his possession." Lave Noles.

"The work needs no commendation. It is indispensable."-Irish Law Times.

The Pocket Law Lexicon.-Explaining Technical Words, Phrases and Maxims of the English, Scotch and Roman Law. Fourth Edition. By Joskpr E. Morris, Esq., Barrister-at-Law. $1905 . \quad 68.6 d$. "A wonderful little legal Dictionary."-Indermaur's Law Students" Journal.

Wharton's Law Lexicon,-Forming an Epitome of the Law of England, and containing full Explanations of Technical Terms and Phrases, both Ancient and Modern, and Commercial, with selected Titles from the Civil, Scots and Indian Law. Tenth Edition. With a New Treatment of the Maxims. By J. M. Lksr, Esq., Barrister-at-Law. Super-royal 8vo. 1902. 1l. 18s.

"An encyclopedia of the law."

"Of the many books we have to refer to in our work no volume is, we believe, more often taken down from the shelf than "Wharton." -Law Notes.

- All standard Law Works are kept in Stock, in law calf and othor bindings. 


\section{DIGESTS.}

MEWS' DIGEST OF ENGLISH CASE LAW.-Containing the Reported Decisions of the Superior Courts, and a Selection from those of the Irish Courts, to the end of 1897. (Being a New Edition of 'Fisher's Common Law Digest and Chitty's Equity Index.") Under the general Editorship of Joms Mrws, Barrister-at-Law. 16 vols. Roy. 8vo. $£ 20$ (Bound in half calf, gilt top, £3 net extra.)

"A vast undertaking . . . . indispensable to lawyers."-The Times.

Decennial Digest (The).-Being the Digest of English Case Law, containing the Reported Decisions of the Superior Courts, and a Selection from those of the Scotch and Irish Courts, with a collection of Cases followed, distinguished, explained, commented on, overruled or questioned from 1898 to 1907 , inclusive, forming a Supplement to Mews' Digest of English Case Law, 16 vols. By Edward. Masson, Esq., Barrister-at-Law. 2 vols. Royal 8vo. 1908. 3l. 3s.

The Annual Digest from 1898 to 1908,-By JoHs Mrws, Esq., Barrister-at-Law. Royal 8vo. (May be had separately.) each 15s.

* This Digest is also issued quarterly, each part being cumulative. Price to Subscribers, for the four parts payable in advance, net 178 .

"The practice of the law without Mews' Annual would be almost an impossibility."-Law Times.

Mews' Digest of Cases relating to Criminal Law down to the end of 1897.-By Jorn Mews, Esq., Barrister-at-Law. Royal 8vo. 1898.

$1 l .58$.

Law Journal Quinquennial Digest, 1901-1905.-An Analytical Digest of Cases. By J JMres S. Henderson, Esq., Barrister-at-Law. 1906.

1l. $10 \mathrm{~s}$.

Talbot and Fort's Index of Cases Judicially noticed, 1865 to 1905.-Second Edition. Being a List of all Cases cited in Judgments reported in all the Reports from 1865 to 1905 ; as also a Statement of the manner in which each case is dealt with in its place of Citation. By M. R. Mrнта, Esq., Barrister-at-Law. Royal 8vo. 1908.

1l. $18 s$.

"The work is extremely well done."-Law Quarterly Review.

Woods and Ritchie's Digest of Cases, Overruled, Approved, and otherwise dealt with in the English and other Courts: with a selection of Extracts from Judgments referring to such Cases. By W. A. G. Woods, LL.B., and J. RrTchie, M.A., Esqrs., Barristers-at-Law.-Founded on "Dale and Lehmann's Digest of Cases Overruled, \&c." 3 Vols. Royal 8vo. 1907.

"Indispensable in every branch of the law."-Law Journal.

"Of great use to the Profession."-Law Times.

DISCOVERY.-Bray's Digest of the Law of Discovery, with Practice Notes,-By EDWARD BRAY, Esq., Barrister-at-Law. Demy 8vo. 1904 .

Net, 38 .

DISTRESS.-Oldham and Foster on the Law of Distress. Second Edition. By Arthur Oldhay and A. LA Trobr Foster, Esqrs., Barristers-at-Law. Demy 8vo. 1889.

$18 s$.

DISTRICT COUNCILS.-Chambers' Digest of the Law relating to District Councils, Ninth Edition.-ByG.F. Chaмrakrs, Esq., Barrister-at-Law. Royal 8vo. 1895.

Cornish's District Councils,-A concise Guide to their Powers and Dnties. By H. D. CorNisH, Esq., Barrister-at-Law. Demy 8 vo. 1908.

78. $6 d$.

"MIr. Cornish has digested into a small space the multifarious duties and rights of district councils with considerable skill. References are made to statutes, with copious citation of cases, and the text is clearly written. Theprincipal subjects are arranged in alphabetical order, and discussed at some length."-Law Times.

** All standard Law Works are kept in Stock, in law calf and other bindings. 
DIVORCE._-Browne and Powles' Law and Practice in Divorce and Matrimonial Causes.-Seventh Edition. By L. D. PowLss, Esq., Probate Registrar, Norwich. Demy 8vo. 1905. 1l. 58. "The practitioner's standard work on divorce practice." - Law Quar. Rev.

DOGS.-Emanuel's Law relating to Dogs.-By Montague $R$. Exanuel, Esq., Barrister-at-Law. Demy 12mo. 1908. 3s. 6d.

EASEMENTS.-Goddard's Treatise on the Law of Easements.-Bx JoHs LeYbourn Goddard, Esq., Barrister-at-Law. Sixth Edition. Demy 8vo. 1904.

"Nowhere has the subject been treated so exhaustively, and, we may add, so scientifically, as by Mr. Goddard. We recommend it to the most careful study of the law student, as well as to the library of the practitioner." - Law Times.

Innes' Digest of the Law of Easements.-Seventh Edition. By L. C. Innes, late Judge High Court, Madras. 12mo. 1903. 7s. 6d.

"Presents the law in a series of clearly enunciated propositions, which are supported by examples taken in general from decided cases." - Solicilors' Journal.

Roscoe's Digest of the Law relating to the Easement of Light. - With an Historical Introduction, and ни Appendix containing Practical Hints for Architects and Surveyors, Obserrations on the Right to Air, Statutes, Forms and Plans. Fourth Edition. By E. S. Roscoe, Esq., Barrister-at-Law. Demy 8vo. 1904. 7s. $6 d$. "A clear and practical digest of the law."-Law Times.

ECCLESIASTICAL LAW.-Phillimore's Ecclesiastical Law.-Second Edition. By Sir W. G. F. Phunmore, Bart., assisted by C. F. J вммктт, Barrister-at-Law. 2 vols. Royal 8ro. 1895. Published at $3 l .3 s$. , reduced to, net, $1 l .5 s$.

"Everything that the ecclesiastical lawyer can possibly need to know." Lavo Journal.

Whitehead's Church Law.-Being a Concise Dictionary of Statutes, Canons, Regulations, and Decided Cases affecting the Clergr and Laity. Second Edition. By Bensasms Whutrhead, Esq., Barristerat-Law. Demy 8vo. 1899

10s. $6 d$.

ELECTIONS.-Hedderwick's Parliamentary Election Manual. Designed for the Instruction and Guidance of Candidates, Agents, Canvassers, Volunteer Assistants, \&c. Second Edition. By T. C. H. Hrddkewick. Eaq.. Barrister-at-Law. Demy $12 \mathrm{mo.} 1900.10$. $10 d$.

Hunt's Guide to Metropolitan Borough Councils Elections. By Jorr Huxt, Esq., Barrister-at-Law. Demy 8vo. 1900. 3s. 6d.

Rogers' Law and Practice of Elections.-

Vol. I. Reorstration, including the Practice is Regintration Appeals; Parliamentary, Municipal, and Local Government; with Appeudices of Statutes, Orders in Council, and Forms. Seventeenth Editiou. By Madriok Powkis, Eaq., Barrister-at-Law. Royal $12 \mathrm{mo}$.

(In the press.)

"The practitioner will find within these covers everything which he can be expected to know, well arranged and carefully stated."-Lavo Times.

Vol. II. Parlumantary Enections and Petrtions; with Appendices of Statutes, Rules and Forma, and a Precedent of a BIII of Costs. Eighteenth Edition. By C. Wincovonby Wrurass, E*q., Barristerat-Law. Royal $12 \mathrm{mo.} 1906$.

1l. $1 s$.

"The acknowledged authority on election law."-Law Journal.

"The leading book on the difficult subjects of elections and election petitions."-Law Times.

Vol. III. Municipar and othkB Elkctions axd Petrimong, with Appendices of Statutes, Rules, and Forms, and a Precedent of a Bili of Costs. Eighteenth Edition. By C. Wruodonвy Wrimass, Esq., assisted by G. H. B. KrNrick, Esq., LL.D., Barristers-at-

Law. Royal $12 \mathrm{mo.} 1906$. 16. 18 .

"A complete guide to local elections." - Solicitors' Journal.

- All standard Law Workx are kevt in Stock, in law ealf and other bindings. 
EMPLOYERS" LIABILITY.-Knowles._-Vide "Workmen's Compensation."

ENGLISH LAW.-Campbell's Principles of English Law Founded on Blackstone's Commentaries. By RoBERT CasmpBELr, Esq., Barrister-at-Law, Editor of "Ruling Cases," \&c. Demy 8vo. 1907. 208.

"It is a good work, this, and ably written, and we can thoroughly recommend - we would go further and say. advise-to all students of English law a careful and conscientious perusal of its pages."-Law Students' Journal.

"The ground covered is practically that occupied by Stephen's Commentaries, and for completeness and clearness of exposition these six hundred odd pages compare very favourably indeed with the older work."-Law Notes.

"A work of all-round excellence, which may be commended, not only to the student, but also to the fully qualified lawyer. In conclusion, one may state that the index is a safe and a sure guide to the contents of the book."-Law Magazine.

Pollock and Maitland's History of English Law before the time of Edward I. Second Edition. 2 vols. roy. 8vo. 1898.

ENGLISH REPORTS. Re-issue of all Decisions prior to 1866. To be completed in about 150 Volumes. Royal 8vo. Issued monthly.

\section{Now Issued.}

House of Lords (1694 to 1866). 11 Vols. Half-bound. Net, $22 l$.

Privy Councrl (Including Indian Appeals) (1809 to 1872). 9 Vols. Half-bound. $\quad$ Net, 13l. 10s.

Cranckry (Including Collateral Reports) (1557 to 1866). 27 Vols. Half-bound.

Rolls Court (1829 to 1866). 8 Vols. Half-bound. Net, $12 l$.

Vice-Chancellors' Courts (1815-1865). 16 Vols. Half-bound.

Now Publighing.

Net, $24 l$.

King's Bench and Quens's Bench (1378-1865). Complete in about 40 Vols. (Vols. I. to XXII. now ready.) Net, per vol., 1l. 10s.

** The Volumes are not sold separately. Prospectus on application.

"We can speak unhesitatingly of the advantage to the lawyer of the possession of this excellent repriut of all the English reports."-Solicitors' Journal.

\section{EQUITY, and Vide CHANCERY.}

Seton's Forms of Judgments and Orders in the High Court of Justice and in the Court of Appeal, having especial reference to the Chancery Division, with Practical Notes. Sixth Edition. By Cecil C. M. Dale, Esq., Barrister-at-Law, W. Tindal King, Esq., a Registrar of the Supreme Court, aud W. O. GolDschmmor, Esq., of the Registrars' Office. In 3 vols. Royal 8vo. 1901. 6l. 6s.

"The new edition of 'Seton' is from every point of view, indeed, a most valuable and indispensable work." - Law Journal.

Smith's Manual of Equity Jurisprudence.-A Manual of Equity Jurisprudence for Practitioners and Students, founded on the Works of Story and other writers, comprising the Fundamental Principles and the points of Equity usually occurring in General Practice. Fifteenth Edition. By Sydney E. Whunams, Esq., Barrister-atLaw. Demy 8vo. 1900.

12s. $6 d$.

Smith's Practical Exposition of the Principles of Equity, illustrated by ihe Leading Decisions thereon. For the use of Students and Practitioners. Fourth Edition. By H. Antrus Sirtr, M.A., LL.B., Esq., Barrister-at-Law. Demy 8vo. 1908.218.

"A well-known book, useful to both practitioner and student alike."-Lavo Student's Journal.

"Students and practitioners will find in it a clear and accurate exposition of the leading principles of Equity." - Law Notes.

Williams' Outlines of Equity.-A Concise View of the Principles of Modern Equity. By Sydney E. Wir.rams, Esq., Barrister-at-Law, Author of "The Law relating to Legal Representatives," \&c. Royal 12mo. 1900.

58.

"The accuracy it combines with conciseness is remarkable."-Lave Magasine.

** All standard Law Works are kept in Stock, in law calf and other bindings. 
ESTATE DUTIES.-Freeth.-Tide "Death Duties."

ESTOPPEL.-Everest and Strode's Law of Estoppel. By Lanckiot Friudno Everkest, and Edmonn Strode, Erqra.. Barristereat-Law. Second Edition by Lavcelot Frmorno Everest, Esq., Barrister-at-Law. Demy 8vo. 1907.

258.

"Will be of great value to the practitioner."-Law Journal.

"A safe and raluable guide to the difficult subject with which it deals. . . An excellent book."-Law Quarterly Reviev.

EVIDENCE.-Bodington.-Vide "French Law."

Wills' Theory and Practice of the Law of Evidence.-By Wx. Wrrts, Esq., Barrister-at-Law. Second Edition. By the Anthor and Thorstox Lawes, Esq., Barrister-at-Law. Demy 8vo. 1907. 15 s.

"For the student it takes a first place, and for the practitioner it will be found to deal in clear and precise form with every question of evidence ordinarily arising in the conduct of a case." - Lraw Journal. Notes.

"Of great valne, not onls t) students but to practitioners generally."-Law

"We heartily commend this new issne of an excellent book."-Law Times.

EVIDENCE ON COMMISSION. - Hume-Williams and Macklin's Taking of Evidence on Commission : including therein Speiial Examinations, Letters of Request. Mandamus and Examinations before an Examiner of the Court. Second Edition. By W.E. Huxs-Willuxs, Esq.. K.C., and A. Romer MLackurs, Eqq., Barrister-at-Law. Demy 8vo. 1903.

$12 s, 6 d$.

"An accurate and complete manual on this important branch of the law. Every point that is likely to oceur in practice has been noted, and there are appendices of statutes, rules, orders, precedents."-Law Times.

EXAMINATION GUIDE.-Barham's Students' Text-Book of Roman Law.-Second Edition. By C. Nicolas Barhas, Esq., Barrister-at-Law. Demy 12mo. 1908. 3s.6d.

"A first primer of Roman Law for the beginner. It is plain and clear, is well arranged, and so simply put that any student can follow it." - Law Student's Journal.

EXECUTORS. -Goffin's Testamentary Executor in England and Elsewhere. By R. J. R. Gofrs, E*q.. Barrister-at-Law. Demy Sro. 1901.

Ingpen's Concise Treatise on the Law relating to Executors and Administrators.-By Arthur Robert INGPes, E*q., one of His Majesty's Counsel. Royal 8ro. 1908.

11. 58 .

"The bisok may be recuramended, wirh ennfldence, as ac :urate, practical, and learned."-Lavo Quarterly Revinr. J4n. 1909.

"The work expresses in a concise form the general prineiples of the law relating to exeeutors and admini-tritors. . . . Mr. Iugpen has undoubtedly done his work well, and the present rolume should prove of great value."-Iravo Times.

"The work meets a real want. . . . The work is on carefully une, and with such weight of authority behind it, that it my almost be taken ge an authoritative statement of the law..... We can heartily recommend his work as an iuvaluable aid both to the prietitioner and student." - Law Journal.

Williams' Law of Executors and Administrators. - Tenth Edition. By the Right Hou. Sir Rolans Vauohan W ILliams " Lord "Iustice of Appeal, and A rthur Robert INopks, Esq., one of His Majesty's Counsel. 2 vols. Roy. 8vo. 1905.

$4 l$.

- We eannot call to mind any work of recent times of greater nuthority than - Williams on Executors.' It is one of our legal classios, and is unrivalled in the width of its range, the accuracy of its statements, and the soundnass of its law. The new edition is worthy of the great reputation of the work, and every prident practitioner wall do well to possess himself of a copy." - Inaw Times

"This book - the standard work on its subject-is a storehouse of learning on every point of administrution law, aud has been completely brought up to date." - Lave Journat.

"A work which every practitioner should possess and n" library should be without." - Law Quarterly Reviete.

$\because$ All standard Law Works are kept in Stock. in lave calf and other bindings. 


\section{EXECUTORS-continued.}

Williams' Law relating to Legal Representatives, - Being a Cencise Treatise on the Law of Executors and Administrators, as modified by the Land Transfer Act, 1897. Second Edition. By Sydney E. Wririams, Esq., Barrister-at-Law, Author of "Law of Account," "Outlines of Equity," \&c. Demy 8vo. 1908. 9s.

"We can commend it to both branches of the profession, and more especially to solicitors."-Law Times.

EXECUTORS (Corporate).-Allen's Law of Corporate Executors and Trustees. By Ernest King Allen, Esq., Barrister-at-Law. Demy 8vo. 1906.

$6 s$.

EXTRADITION.-Biron and Chalmers' Law and Practice of Extradition. By H. C. Biron and Kenneth E. Chalmers, Esqrs., Barrister8-at-Law. Demy 8vo. 1903.

"A very satisfactory and pructical collection of the treatio and statutes relating to extradition and fugitive off +nders, with an interesting introduction, a commentary on the text of the statutes and tr aties, and a valuable alphabetical list showing what crimes are comprised in the particular treaties."-Law Journal.

FACTORIES AND WORKSHOPS._Ruegg and Mossop's Law of Factories and Workshops. By A H. RUEGG, Esq., K.C., and L. Mossop, Esq., Barrister-at-Law. Demy 8vo. 1902.' 12s.6d.

FARM, LAW OF.-Dixon's Law of the Farm: including the Caser and Statutes relating to the subject; and the Ayricultural Customs of England and Wales. Sixth Edition. By Aubrery J. Spencer, Esq., Barrister-at-Law. Demy 8vo. 1904. 1l. 68.

"A complete modern compendium on agricultural matters."-I.an Times.

Spencer.-Vide "Agricultural Law."

FIXTURES.-Amos and Ferard on the Law of Fixtures. Third Edition. By C. A. Frrard and W. Howland Robkrts. Enyrs., Barristers-at-Law. Demy 8vo. 1883.

$18 s$.

FORMS.-Chitty's Forms of Civil Proceedings in the King's Bench Division of the High Court of Justice, and on Appeal therefrom to the Court of Appeal and the House of Lords.Thirteenth Edition. By T. W. CHITTY, Esq., a Master of the Supreme Court, Herbert Chitty, Esq., Barrister-at-Law, and P. E. Vizard, Esq., of the Central Office. Royal 8vo. 1902. 1l. 16s.

"The book is accurate, reliable and exhuustive."-solicitor.' Journal.

"The forms are practically exhaurtive, and the notes very good, so that this edition wlll be invaluable to practitioners whoxe work is of th litigious kind."Law Journal.

Daniell's Forms and Precedents of Proceedings in the Chancery Division of the High Court of Justice and on Appeal therefrom.-Fifth Edition, with sumwaries of the Rules of the Supreme Court; Practical Notes: and references to the Seventh Edition of Daniell's Chancery Practice. By Cearles Burney, B.A., a Master of the Supreme Court. Royal 8vo. 1901. 2l. 10s.

"The standard work on Chancery Procedure."-Law Quarterly Raview.

Seton.-Vide "Equity."

Wolstenholme's Forms and Precedents.-Adapted for use under the Conveyancing Acts and Settled Land Acts, 1881 to 1890. Sixth Edition. Royal 8vo. 1902.

1l. 18.

FRENCH LAW.-Bodington's Outline of the French Law of Evidence.-By Oliver E. Bodington, Esq., Barrister-at-Law. Demy 8vo. 1904.

Cachard's French Civil Code. - By Henry Cachard, B.A., Counsellor-at-Law of the New York Bar, Licencié en Droit de la Faculté de Paris. Demy 8vo. 1895.

* All standard Law Works are kept in Stock, in law calf and other bindings. 
FRENCH LAW-continued.

Goirand's Treatise upon French Commercial Law and the Practice of all the Courts. - With a Dictionary of French Judicial Terms. Second Edition. By Leopom Gorrasd, Licencié en Droit. Demy 8vo. 1898.

Goirand's Treatise upon the French Law relating to English Companies carrying on Business in France.-By Lropor. Gorraxd, French Srilicitor. Crown 8vo. $1902 . \quad$ Net, 2s.6d.

Kelly.-Tide " Marriage."

Pellerin's French Law of Bankruptcy, and Winding-up of Limited Companies, the Conflict of Laws arising therefrom. Bv Prrere Pelleris, A vocat, of Paris and Lincoln's Inn. 8vo. 1907. Net, 2s. $6 d$.

Pellerin's French Law of Wills. Probate Administration and Death Duties of the Estates of Deceased Englishmen leaving Property in France.-By Pierre Pellers, Avocat, of Paris and Lincoln's Inn. Demv 12mo. 1909. Net $2 s$.

Sewell's Outline of French Law as affecting British Subjects. By J. T. B. Sewkid, LL.D., Solicitor. Demy 8vo. 1897. 10s. $6 d$.

Wright's French Civil Code (as amended up to 1906), translated into English, with Notes Explanatory and Historical, and Comparative References to English Law. By E. Brackwoon Wвiонт, Ekq., LL.D., Chief Justice of Seychelles. Roya] 8vo. $1908 . \quad 11.58$.

FRIENDLY SOCIETIES. - Fuller's Law relating to Friendly Societies.-Third Edition. By Frask Badex Fulrer, Esq., Barrister-at-Law.

(In preparation.)

GAMBIA.-Ordinances of the Colony of the Gambia. With Index. 2 Vols. Folio. 1900. Net, 3 ?.

GOLD COAST.-Ordinances of the Gold Coast Colony and the Rules and Orders thereunder. 2 rols. Royal Sro. 1903. 37. 10 s.

GOODWILL.-Allan's Law relating to Goodwill.-By Charrfs E. Aluan, M.A.,LL. B., Esq., Barrister-at-Law. Demy8ro. 1889. 7\&.6d. Sebastian.- Tide "Trade Marks."

HOUSE TAX.-Ellis' Guide to the House Tax Acts, for the use of the Payer of Inhabited House Duty in England.-By A rthur M. Elirs, LL.B. (Lond.), Solicitor. Roval 12mo. 1885. 6s.

HUSBAND AND WIFE.-Lush's Law of Husband and Wife. Third Edition. By W. Hussey Grifrtth, Esq., Barrister-at-Law.

(In preparation.)

INCOME TAX.-Buchan's Law relating to the Taxation of Foreign Income.-By Jors Bccirsx, Esq., Barrister-at-Law, with Preface by the Right Hon. R. B. Haldane, K.C., M.P. Demy 8 vo. 1905 .

"A text book of great value."-Lave Journal.

Ellis' Guide to the Income Tax Acts.-For the use of the English Income Tax Payer. Third Edition. By Artrus M. Eliss, LL.B. (Lond.), Solicitor. Royal 12mo. 1893.

Fry's Income Tax.-The Finance Act, 1907, in its Relation to Income Tax. Second Edition. By T. HALLETT Fry, Ezq.. Barristerat-Law. Royal 12mo. 1909.

Net, 2s. 6d.

Robinson's Law relating to Income Tax; with the Statutes, Forms, and Decided Cases in the Courts of England, Scotland, and Ireland.-Second Edition. By Artuor Robinson, Esq., Barriaterat-Law. Royal 8vo. 1908.

"A standard work on the subject."-Lare Journal.

"The book is both practical and well arranged."- Snlicirnrs' Jrurnnt.

Whybrow's Income Tax Tables.-By G. H. Wrysrow, Esq., of the Income Tax Repayment Branch, Somerset House. Demy 8ro. 1905. 5s.

"This is a very useful book. and will be found of exceptional value to bankrrs, solicitors, oftrials of public companies aud other professional men." Financial Times.

- All standard Law Works are kept in Stock, in law calf and other bindings. 
INDIA.-Ilbert's Government of India.-Second Edition. By Sir Courtr nay Il.bert, K.C.S.I. Demy 8vo. 1907. Net, 10s. 6j.

INDICTMENTS.-Bowen-Rowlands.- tride "Criminal Law."

INLAND REVENUE. - Highmore's Summary Proceedings in Inland Revenue Cases in England and Wales. Including Appeals to Quarter Sessions and by Special Crse, and Proceedings by Collector's Warrants for Recovery of Duties of Excise and Taxes. Third Edition. By Sir N. J. Нrянмоке, Barrister-at-Law, Assistant Solicitor of Inland Revenue. Rny. 12mo. 1901. 7s.6d. Highmore's Inland Revenue Regulation Act, 1890, as amended by the Publir: Accounts and Charges Act, 1891, and the Finance Act, 1896, with nther Acts: with Notes, Table of Cases, \&o. By Sir Nathaniel J. Highmonk. Barrister-at-Law, Assistant Solicitor of Inland Revenue. Demy 8vo. 1896.

INSURANCE,-Arnould on the Law of Marine Insurance and Average.- Eighth Edition. By EnwARd Lours DE HART and RALPH InIFF SIMEx, Esqrs., Barriaters-at-Law. 2 vols. Roy. 8vo. 1909.

$3 l .3 s$.

"A rnould's 'Marine Insurance' is recognised throughout the British Empire and the United States as a tandard work of almost judicial autherity, and in the hands of its pre ent editars it is likely to maintain that position and atrengthen it. . . . It is not the le ast merit of the bcok that it is well written, ard in roint of style, as well as arrsngement and reliability, it may fairly be describfd as a model treatise."-Law Joumal, Feh, 6th. 1909.

"Among the more important matters which are treated with special fulness are, insurable interest, warranties, express and implied, general and particular average, and constructive total lnss, and on any of these the work will be found to be a mine of judicial precedent and actual practicu."-Solicitors' Journal.

De Hart and Simey's Marine Insurance Act, 1906. With Notes and an Appendix. By Edward Louis dr Hart and RaLPH InIFF Sncry, Esqrs., Barristers-at-Law, Joint Editors of "Arnould on Marine Insurance" and "Smith's Mercantile Law." Royal 8vo. 1907.

$6 s$.

"The notes to the sections of the Act are extremely well done, and the references to casea are full. ... We can imagine no more useful guide to the new Act."-Law Journal.

INTERNATIONAL LAW.-Dicey. - Tide "Conflict of Laws."

Hall's International Law.-Fifth Edition. By J. B. Atray, Esq., Barrister-at-Law. Demy 8vo. 1904. Net, 1l. 1s.

Hall's Treatise on the Foreign Powers and Jurisdiction of the British Crown. By W. E. Hadx, Esq., Barrister-at-Law. Demy 8 ro. 1894.

10s. $6 d$.

Higgins' The Hague Conference and other International Conferences concerning the Laws and Usages of War-Texts of Conventions, with Notes.-By A. Pearce Hragrs, M.A., LL.D., sometime Scholar of Downing College. Royal sro. 1904. Net, 3s.

Holland's Studies in International Law.-By Thomas Erskine Hor.and, D.C.L., Barrister-at-Law. Demy 8vo. 1898. 10s. 6d.

Holland's Gentilis Alberici de lure Belli Libri Tres,-Edidit T. E. HolmaNd, I.C.D. Small 4to., half morocco. 1l. 1..

Nelson's Private International Law.-By Horack Nerson, Esq., Barrister-at-Law. Roy. 8vo. 1889.

Rattigan's Private International Law.-By Sir Wrumax HeNRr Ratrigan, LL.D., K.C. Demy 8vo. 1895. $10 s .6 \pi$.

"Written with admirable clearness." - Law.Journal.

Takahashi's International Law applied to the Russo-Japanese War. With the Decisions of the Japanese Prize Courts. By S $\triangle$ KUYE Takamasmi, Esq., Professor of Interuational Law in the Imperial University of Tokyo. Royal 8vo. 1908.

Net, 1l. 12s.

Walker's History of the Law of Nations.-Vol. I., from the Earliest Times to the Peace of Westphalia, 1648. By T. A. WALKER, M.A.

LL.D., Esq., Barrister-at-Law. Demy 8vo. $1899 . \quad$ Net, 10s.

* All standard Law Works are kept in Stock, in law calf and other bindings. 


\section{INTERNATIONAL LAW-continued.}

Walker's Manual of Public International LaW.-By T. A. W M.A., LL.D., Esq., Barrister-at-Law. Demy 8vo. 1895. 98.

Westlake's International Law.-Chapters on the Principles of International Law. By J. W gstuake, K.C., LL.D. Demy 8vo. 1894. 10 s.

Westlake's International Law.-By J. Westhake, K.C., LL.D.

Part I. Peace. Demy Svo. 1904. Net, 9 s. Part II. War. Demy Sro. 1907.

Net, $9 s$.

Wheaton's Elements of International Law: Fourth English Edition. Including a translation of the Anglo-French Agreement. By J. B. Aruay, M.A., Barrister-at-Law. Royal 8vo. 1904. 11. $12 s$.

"Wheaton stands too high for criticism "-L Ine Times.

"We congratulate Mr. Atlay on the skill and dismretion with whicb he has performed the takk of editing a atandard treatise nn international law." - L m Journal.

INVESTIGATION OF TITLE.-Jackson and Gosset's Investigation of Title.-Being a Practical Treatise and Alphatetical Digest of the Law connected with the Title to Land, with Precerlents of Requisitions. By W. Howland Jackson and Thoвowd Gosser, Ekqrs., Barristers-at-Law. Third Edition. Br W. Howtand Jackson, Esq., Barrister-at.Law. Demy 8vo. 1907. 15 .

"The merits of the brok are excellent."-Law Jou-nal.

"Will be of real help to the busg conveyancer." - L.e Nites.

JUDGMENTS AND ORDERS.-Seton.-I Tide " Equity."

JURISPRUDENCE.-Holland's Elements of Jurisprudence. -Tenth Edition. ByT.E. Howuavd, K.C., D.C.L. 8vo. 1906. 10s.6d.

Markby's Elements of Law. Sixth Edition. By Sir Wilurax MARKBY, D.C.L. Demy 8ro. 1905. 12s. 6d.

JURY LAWS. - Huband's Practical Treatise on the Law relating to the Grand Jury in Criminal Cases, the Coroner's Jury, and the Petty Jury in Ireland.-By Wx. G. Hubasd, Esq., Barrister-at-Law. Royal 8vo. $1896 . \quad$ Net, 1l. 58.

JUSTICE OF THE PEACE.-Magistrates' Cases, 1895 to 1908,-Cases relating to the Poor Law, the Criminal Law, Licensing, and other subjects chiefly connected with the duties and office of Magistrates. 1895-1909.

Each, net $1 l$.

* These Reports, published as part of the Law Journal Reports, are issued Quarterly. Each Part, net 5 s.

Annual Subscription, payable in advance, 15s. post free.

Magistrate's General Practice,-A Compendium of the Law and Practice relating to Matters occupying the attention of Courts of Summary Jurisdiction, with an Appendix of Statutes and Rules, List of Punishments, Ca'endar for Magistrates, Sce. By Charles Mrlve A Arrsson, Eeq., Stipendiary Magistrate for Leeds. Demy 8vo. 1909.

$20 s$.

"The book is excellently produced, and, notwithstanding its 1,200 odd pages, it is as convenient in form as it is in arrangement, and may be regurded as the vade mecum ot Practitioners in the Magistrates' Courts "-l,aw Jour., Mar. 13, '(u. .

Wigram's Justice's Note-Book,-Containing a short account of the Jurisdiction and Duties of Justices, and an Epitome of Criminal Law. Eighth Edition. By Leonard W. Kreshaw, Esq., Barrister-atLaw. Royal 12mn. 1908. is. $6 d$.

"The information given is romplete and arcurate."-Lnto .Jnurnal.

"There is no better book for a justice of the peace to bus, to read, and to understand."-Lav Times.

$\because$ All standard Law Works are kept in Stock, in hace calf and other bindings. 
LAND CHARGES ACTS. - Eaton and Purcell's Land Charges Acts, 1888 and 1900.-A Practical Guide to Registration and Searches. By Ernest W. Eaton, Esq., and J. Poyntz Puroric, Esq., of the Land Charges Department, Land Registry. Royal $12 \mathrm{mo.}$ 1901.

Net, 2s. 6d.

LAND LAW.-Jenks' Modern Land Law. By EdWARD J HNKs, Esq., Barrister-at-Law. Demy 8vo. 1899.

$15 s$. Jolly.-Vide "Covenants."

Leake.-Vide "Real Property."

LAND TAX.-Bourdin's Land Tax.-An Exposition of the Land Tax. Fourth Edition. By the late Frederack Humphraxs, Deputy Registrar of Land Tax ; and Digests of Cases decided in the Courts by Charles C. Atcmison, Deputy Registrar of Land Tax. Royal 12mo. 1894.

7s. $6 d$.

Atchison's Land Tax,-Changes Effected in the Processes of Assessment and Redemption by Part VI. of the Finance Act, 1896 (59 \& 60 Vict. c. 28). By Chardies C. Atchison, Deputy Registrar of Land Tax. Royal 12mo. 1897. (A Supplement to above.) Net, 2s.6d.

LAND TRANSFER.-Brickdale and Sheldon's Land Transfer Acts, 1875 and 1897.-With a Commentary on the Sections of the Acts, and Introductory Chapters explanatory of the Acts, and the Conveyancing Practice thereunder; also the Land Registry Rules, Forms, and Fee Order, Orders in Council for Compulsory Registration, \&c., together with Forms of Precedents and Model Registers, \&c. By C. Forterscue BrICKDale, Registrar at the Land Registry, and W. R. Shrudon, Esqrs., Barristers-at-Law. Second Edition. By C. Fortescur Brickdate, Esq. Royal 8vo. $1905 . \quad 11.5 s$.

"The second edition of this book will be welcomed by the practitioner whc has to do with registered land, or with conveyancing of any kind in London, where registration on sale is now compulsory." - Law Quarterly Review.

"Contains not only lengthy and valuable notes and annotations on the Land Transfer Acts and Rules, but also full and separate dissertations on the law, procedure, and practice thereunder."-Lav Times.

Hogg's Precedents.-Vide "Conveyancing."

Jennings and Kindersley's Principles and Practice of Land Registration under the Land Transfer Acts,-By A. R. G. Jennings, LL.B., and G. M. KINDERsLey, Esqrs., Barristers-atLaw, and of the Land Registry. Roy. 8vo. 1904. 12s.6d.

"The principles and practice of land registration are set forth in a clear and concise manner by the authors in their dissertations and notes."-Law Times.

LANDLORD and TENANT.-Redman's Law of Landlord and Tenant.-Including the Practice of Ejectment. Fifth Edition. By Joseph H. Redoman, Esq., Barrister-at-Law. 8vo. 1901. 1l. 5 s.

"We can confidently recommend the present edition."-Law Journal.

Woodfall's Law of Landlord and Tenant,-With a full Collection of Precedents and Forms of Procedure; containing also a collection of Leading Propositions. Eighteenth Edition. By W. H. Aags, Esq., Barrister-at-Law. Roy. 8vo. $1908 . \quad 1$ 1l. $18 s$.

"Woodfall is really indispensable to the practising lawyer, of whatever degree he may be."-Law Journal.

LANDS CLAUSES ACTS.-Jepson's Lands Clauses Acts ; with Decisions, Forms, and Tables of Costs. Second Edition. By J. M. Lrantwood, Esq., Barrister-at-Law. Demy 8vo. 1900. 1l. $1 s$.

"A handy and well-arranged treatise."-Solıcilors' Journal.

LAW.-Where to Look for your Law. As set out in the latest Legal Text-Books, Alphabetically Arranged, with Dates of latest Authorities. Demy 8vo. 1908. (120 pages.) Net, $1 s$.

"A very useful little guide book."-Law Students' Journal.

* All standard Law Works are kept in Stock, in law calf and other bindings. 
LAW COURTS.-Balm's Our Law Courts, including the Rights and Duties of Judges and Lawyers. - With an Appendix of useful Law Furms. By Alex. J. Bacr, Esq., Barrister-at-Law. Crown 8vo. 1908. Net, 3s.

LAW JOURNAL REPORTS.-Edited by JoHN Mrws, Esq.,

Barrister-at-Law. Published monthly. Annual Subscription:Reports and Public General Statutes Net, $3 l .4 s$. Reps. Stats. \& Mews' Annual Digest (Issued Quarterly) Net, 3l. 10s. Thin paper Edition, forming one handy Vol, for the year Net, $3 l$. $4 s$. Or, without the Statutes

Net, $3 l$.

The Law Journal weekly, 1l. extrs.

Synopsis of Contemporary Reports, 1832 to $1905 . \quad$ Net, $5 s$. Law Journal Quinquennial Digest._I Tide "Digests."

LAW LIST. - Law List (The), - Comprising the Judyes and Otficers of the Courte of Justice, Counsel, Sperial Pleaders, Con reyuncers, Solicitors, Proctors, Noturies, Sc., in England and Wales; the Circuits, Judges, Treasurers, Registrars, and High Bailiffs of the County Courts: Metropolitar and Stipendiary Magintrates, Othicial Receivers uuder the Bankruptuy Act, Law and Public Otticers in England, Colonial nnd Foreign Lawyers with their tingsish Agents, Clerks of the Peace, Town Clerks, Coroners, Consmiswioners for taking Oaths, Converancers Practising in Eugland under Certificates obtuined in Scotland, se., sec. Compiled, so far as relates to Specisl Pleaders, Conveyancers, Solicitors, Proctors and Notaries, by H. F. Bartlets, I.S.O., Coutroller of Stamps, and Registrar of Juint Stock Companies, and Published by the Authority of the Cumrnissioners of Inland Revenue and of the Law Society. 1909 Net, 10s. 6d.

LAW QUARTERLY REVIEW.-Edited by Sir FRKDKRICK Pollocz, Bart., D.C.I., LL.D. Vols. I.-XXIV. (with General Indices to Vols. I. to XX.) Royal 8vo. 1885-190S. Each, 128. 195nual Subscription post free 12s. 6d., net. Single nismbers, each 5s.

"A little criticism, a few quotations, and a batch of anecdotes, afford a sauce that makes even a quarter's law reporting amusing reading."-Law Journal.

"The greatest of legal quarterly reviews. . . the series of - Notes' always so entertaining and illustrative, not merely of the learning of the accomplished jurist (the Editor) but of the grace of language with which such learning can be unfolded." - Lave Jorr.

\section{LAWYER'S ANNUAL LIBRARY}

(1) The Annual Practice.-SNow, Bunnky, and Strinekr.

(2) The A. B C. Guide to the Practice.-Srrivorr.

(3) The Annual Digest. - Mrws. (Alsn Issued Quarterly.)

(4) The Annual Statutes,-Haxbury Agos

(5) The Annual County Court Practice.-SMrty.

(6) The Magistrate's General Practice. - A־ KIss w.

16. Annual Subseription payable "n advunce. (a) Fur Complete Series, as above, delivered on the day of publication, net, 2l. 18s. (b) No8. 1, 2, 3,4 , and 6 only, net, 2l. 8s. (If A. B. C. Guros is not wanted 2s. $6 d$. may be deducted from sutscription to series $(a)$ or $(b)$. (c) Nos. 3, 4, 5, and 6 only, net, 2l. 5s. If Magistrite's General Practice is not uanted 10s. may be deducted fiom any series.) (Carriage extra, 2s.) Full prospectus forwarded on application. 
LEADING CASES.-Kenny, Radcliffe \& Miles, Vide "Torts."

Shirley's Selection of Leading Cases in the Common Law. With Notes. By W. S. SyIrLey, Esq., Barrister-at-Law. Eighth Edition. By Richard Watson, Esq., Barrister-at-Law. Demy 8vo. 1908. 16s.

"This new edition upholds in every way the high standard of excellence with which this work is very rightly associated." -Lav. Students' Jnurnal.

"The selection is very large, though all are distinctly 'Leading Cases,' and the notes are by no means the least meritorious part of the wori." -Law Journal.

Warburton's Selection of Leading Cases in the Criminal Law. With Notes. By HenRY W ARBurTon, Esq., Barrister-at-Law. Fourth Edition. Demy 8vo. 1908.

12s. $6 d$.

"The cases have been well selected, and arranged, . . . We consider that it will amply repay the student or the practitioner to read both the cases and the notes."-J ustice of the Peace.

LEGAL HISTORY.-Deans' Student's Legal History.-Second Edition. By R. Storry Deans, Esq., Barrister-at-Law. Demy 8 vo. 1905.

$6 s$.

LEGAL INTERPRETATION.-Beal's Cardinal Rules of Legal Interpretation, - Collected and Arranged by EdwaRd Beal, Esq., Barrister-at-Law. Second Edition. Royal 8vo. 1908.11.

"This useful compilation of rules and judicial dicta on questions of interpretation of d-cisions contracts, deeds, nills, and statutes has cume to be recognised as a ready means of seference to the law on the subject." - Law Journal.

LEGISLATIVE METHODS.-I Ibert's Legislative Methods and Forms,-By Sir Courtenay Ilbert, K.C.S.I., C.I.E., Parliamentary Counsel to the Treasury. Demy 8vo. 1901. 16..

LEXICON.- ride "Dictionary."

LIBEL AND SLANDER.-Odgers on Libel and Slander.A Digest of the Law of Libel and Slander: and of Actions on the Case for Words causing Damage, with the Evidence, Procedure, Practice, and Precedents of Pleadings, both in Civil and Criminal Cases. Fourth Edition. By W. Bl.AKr Opgkrs, LL.D., one of His Majesty's Counsel, and J. Bromrey Eames, Esq., Barrister-at-Law. Royal 8vo. 1905.

1l. $12 s$.

"A standard and exhaustive tratise on the law of defamation and allied tupi w."-Law Quarterly Review.

"The most scientific of all our law books. . . . In its new dress this volume 1* secure of an appreciative professional welcome."-Law Times.

LICENSING.-Slocombe's Licensing Act, 1904, Simply Stated. - Second Edition. By Azfred J. Slocombe, County Borough Police Court, Huddersfield. Demy 8vo. 1905.

Net, $2 s$.

Talbot's Law and Practice of Licensing, - Being a Digest of the Law regulating the Sale by Retail of Lutoxicating Liquor. Witb a full A ppendix of Statutes, Rules and Forws. Second Edition. By Groboe John Talbot, Esq., Barrinter-at-Law. Royal 12 mo. 1905. $10 s .6 d$.

LIGHT.-Vıde "Eanemeuts."

LIGHT RAILWAYS.—l'ide "Trumwarn."

LOCAL AND MUNICIPAL GOVERNMENT.-Bazalgette and Humphreys' Law relating to County Councils.-Third Edition. By Georoe Humpureys, Esq. Royal 8vo. 1889. Tr. $6 d$.

Bazalgette and Humphreys' Law relating to Local and Municipal Government. By C. NoRMan BazalokTTK and G. Humphrhy, Eaqro., Barrinters-at-Law. Sup. royal zvo. 18x8. Published at 3l. 3s.

Reduced to net, $20 s$.

$\because$ All standard Lau Workn are kept in Stuck, in law calf and other bindinjs. 
LOCAL TAXATION LICENCES.-Highmore's Law and Practice relating to the Duties on the Local Taxation Licences transferred to County Councils in England and Wales as from the lst January, 1909, under the provisions of section 6 of the Finance Act, 1908, and an Order in Council issued thereunder; together with the Circular of the Local Gorernment Board, the Regnlations of the General Post Office, \&c. Second Edition. By Sir Nathaniel J. Hrohrore, of the Middle Temple, Barrister-atLaw, Solicitor for His Majesty's Customs, and from 1890 to 1903

Assistant Solicitor of Inland Revenue. Demy 8vo. 1909.

68 .

"It is so clearly and concisely written that the non-legal mind will find it easy to understand and of invaluable a-sıstance. An admirable example of what a legal handbook ought to be."-Law Times.

LONDON BUILDING ACTS.-Cohen's London 8uilding Acts, 1894 to 1905 . With Introductions and Notes, and the ByeLaw's, Regulations and Standing Orders of the Council, \&c., \&c. By E. Araktr Cohen, Esq., Barrister-at-Law. Royal 8ro. 1906. 25s.

"The work is a decided acquisition to th e library of the local government lawyer, and may be safely recommended as a guide to the difficulties of the Building Acts."-Law Times.

Craies' London Building Act, 1894; with Introduction, Notes, and Index, and a Tuble showing how the Former Enactments relating to Buildings have been dealt with.-By W. F. Crarks, Esq., Barrister-at. Law. Royal 8vo. 1894.

58.

LONDON LOCAL GOVERNMENT. - Hunt's London Local Government. The Law relating to the London County Council, the Vestries and District Boards elected under the Metropolis Management Acts, and other Local Authorities. By Jors HuNT, Esq., Barrister-at-Law. 2 vols. Royal 8vo. $1897 . \quad 3 l .38$.

LUNACY._Heywood and Massey's Lunacy Practice,-Part I. : Disseftatioss, Forms and Precedents. Parts II. \& III.: The LuNacy ACTs, 1890 aNd 1891, and RtLes Fully Awsotated, and an Appendix, with Precedents of Bills of Costs. Third Edition. By N. Arthur Heywood and Arnold S. Massey, Esqrs., Solicitors, and Rasph C. Rouer, Esq., First Class Clerk in the Office of the Masters in Lunacy. Royal 8vo. 1907. 1 l. 58. "In its new and more valuable form the work should be very welcome to all who have to do with this branch of law."-Law Times.

"In its enlarged $f \mathrm{rm}$ the work deserves the favour of the legal profession." - Law Journal.

MAGISTRATES' PRACTICE and MAGISTERIAL LAW. - Vude "Justice of the Peace."

MARINE INSURANCE. - Vide "Innurauce."

MARITIME DECISIONS.-Douglas' Maritime Law Decisions.- Compiled by Roвt. R. Dozoras. Demy 8vo. 1888. is. $6 d$.

MARRIAGE.-Kelly's French Law of Marriage, Marriage Contracts, and Divorce, and the Conflict of Laws arising therefrom. Second Edition. By Orver E. Boninatos, Esq., Burrister-atLaw, Licencié en Droit de la Faculté de Paris. Roy. 9vo. 1895. 1l. 1s.

MARRIED WOMEN'S PROPERTY.-Lush's Married Women's Rights and Liabilities in relation to Contracts, Torts, and Trusts. By Monraour Losu, Esq., Barrister-at-Law, Author of "The Law of Husband and Wife." Royal 12mo. 1887. 58.

* All standard Law Works are kept in Stock, in law calf and other bindings. 
MASTER AND SERVANT.-Macdonell's Law of Master and Servant. Being a Treatise on the Law Relating to Contracts of Service, Apprenticeship, and Eniployment. Part I. Common Law. Part II. Statute Law.-By Sir John Macdoxed, LL.D., C.B., a Master of the Supreme Court. Second Edition. By Edward A. Mitcheli Innes, Esq., K.C. Royal 8vo. 1908. 17.5s.

"The participation of the learned author in the preparation of this edition of his standard work will maintain its high authority as the lcading book on the subject."-Law Journol.

"The rep tation of the original work is not only upheld but is considerably increased by the able pref aration of the new + dition."-Law Times.

MEDICAL PARTNERSHIPS. - Barnara and Stocker's Medical Partnerships, Transfers, and Assistantships,-By Wintiam Barnard, Esq., Barrister-at-Law, and G. Bertram Stocker, Esq., Managing Director of the Scholastic. Clerical and Medical Association (Linited). Demy 8vo. 1895. 10s. 6d.

MERCANTILE LAW.-Smith's Compendium of Mercantile Law.-Eleventh Edition. By Edward Lours de Hart, M.A., LL.B., and Ralpi Iliff Simer, B.A., Esqrs., Barristers-at-Law.

2 vols. Royal 8vo. 1905 . $2 l .2 s$.

"Of the greatest value to the mercantile lawyer."-Larc Times.

"One of the most acientitic treatises extant on mercantile law."-Snlicitors" $J l$.

Tudor's Selection of Leading Cases on Mercantile and Maritime Law.-With Notes. By O. D. TuDor, Esq., Barrister-at-Law. Third Edition. Royal 8vo. $1884 . \quad 2 l .2 s$.

MERCHANDISE MARKS ACT.-Payn's Mercnandise Marks Act, 1887.-By H. PaYs, Barrister-at-Law. Royal 12mo. 1888.

3s. $6 d$.

MINES AND MINING.-Cockburn,-Vide "Coal."

MONEY-LENDERS AND BORROWERS.-Alabaster's Money-Lenders and Borrowers.-The Law relating to the Transactions of Money-Lenders and Borrowers. By C. Grenvil LE Alabaster, Ekq., Bar ister-at-Law. Demy 8ro. 1908.68.

MORALS AND LEGISLATION.--Bentham's Introduction to the Principles of Morals and Legislation.-By J KREMT BrNтHAм, M.A., Bencher of Lincoln's Inn. Crown 8vo. 1879. 68.6d.

MORTGAGE.-Beddoes' Concise Treatise on the Law of Mortgage.-Second Edition. By W. F. BEDposs, Esq., Barrister-atLaw. 8vo. 1909 .

12s. $6 d$.

"In looking over its concike pages and clearly expre-sed propositions, one sees that it is exactly the sort of gude the conveyancer necds for reference."Saturlay Review.

Coote's Treatise on the Law of Mortgages. - Seventh Edition. By Syonex Edward Williams, Esc.., Barrister-at-Law, Author of "The Law relating to Legal Representatives," "The Law of Account," \&c. 2 vols. Royal 8vo. $1904.231 .3 s$.

"The work is very complete, and as a standard book is one to which the lawyer may turn for almost any point he netds in convection with its subject."Law Students' Journal.

"It is essentially a practitiones's book, and we pronounce it 'one of the best." " - Lnw Notes.

MOTOR CARS.-Bonner and Farrant's Law of Motor Cars, Hackney and other Carriages.-An Epitome of the Law, Statutes, and Regulations. Second Edition. By G. A. Bonsur and H. G. Farrant, Esqre., Barristers-at-Law. Demy 8vo. 1904. 128.6d.

"Carefully revised and brought up to date."-Law Times.

* All standard Law Works are kept in Stock, in law calf and other bindings. 
NAVY. - Manual of Naval Law and Court Martial Procedure; in which is embodied Thring's Criminal Law of the Navy, and an Appendix of Practical Forms.-By J. E. R. SткPhens, Esq., Barrister-at-Law, C. E. GrFrond, Esq., C.B., Fleet Paymaster, Royal Navy, and F. Harrison Sxith, Esq., Staff Paymaster, Royal Navy. Deruy 8ro. 1901.

158.

NEGLIGENCE. - Smith's Treatise on the Law of Negligence.

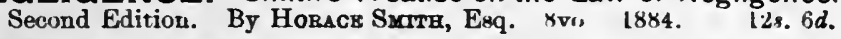

NIGERIA LAWS.-Gollan's Northern Nigeria Law. Royal 8vo. 1905.

$2 l .2 s$.

Richards' Table of Offences of Southern Nigeria. By E. A. Speed, Esq., A.-G. Southern Nigeria. Royal 8vo. 1908. Net, 3s.9d. Speed's Laws of Southern Nigeria. 2 vols. Royal 8vo. 1908. Net, 1l. 108.

NISI PRIUS.-Roscoe's Digest of the Law of Evidence on the Trial of Actions at Nisi Prius.-Eighteenth Edition. By MaUrics Powerl, Esq., Barrister-at-Law. 2 vols. Demy 8vo. 1907. 2l. 2s.

"An indispensable work of reference for the practitioner."-Solicitors" Journal.

"A vast and closelv packed atorehnume of information."-Law Journal.

"Invaluable to a Nisi Prius practitioner."-Law Quarterly Review.

NOTARY.-Brooke's Treatise on the Office and Practice of a Notary of England.-With a full collection of Precedents. Sixth Edition. By James Cranstour, Esq., Barrister-at-Law. Demy 8vo. 1901.

1l. 58.

"The book is an eminently practical one, and contains a very complete collection of notarial precedents."-Law Journal.

OATHS.-Stringer's Oaths and Affirmations in Great Britain and Ireland; being a Collection of Statutes, Cases, and Forms, with Notes und Practical Directions for the use of Commissioners for Oaths, and of all Courts of Civil Procedure and Offices attached thereto. By Francts A. Strinokr, of the Ceutral Office, Royal Courts of Justice. une of the Editor of the "Annual Practice." Eecond Edition. Crown 8vo. 1893.

48.

"Indispensable to all commussioners."-solictors' Journal.

ORANGE RIVER, - The Statute Law of the Orange River Colony.-Translatid. Royal 8vo. 1901.

2l. 28 .

OTTOMAN CIVIL LAW.-Grigsby's Medjellé, or Ottoman Civi! Law.-Translated into English. By W. E. Griosbr. LL.D., Esq., Barrister-at-Law. Demy 8vo. 1895.

1l. 18.

PARISH LAW. - Humphreys' Parish Councils, - The Law relating to Parish Councils. Second Edition. By Georor HoxPERkY8, Esq., Barrister-at-Law. Royal 8ro. $1895 . \quad 10 s$.

Steer's Parish Law. Being a Digest of the Law relating to the Civil and Ecclesiastical Government of Parishes and the Relief of the Poor. Sixth Edition. By W. H. Macnamara, Esq., Assistant Master of the Supreme Court. Demy 8vo. 1899.

PARTNERSHIP.-Aggs' Limited Partnerships Act, 1907. With Rules and Forms thereuuder. By W. HANBUry AGGS, Esq., Barrister-at-Law. Royal svo. 190S.

Net, $1 s .6 d$.

Pollock's Digest of the Law of Partnership. With an Appendix of Forms. Eighth Edition. By Sir Fredreicr Pollock. Bart., Barrister-at-Law, Author of "Principles of Coutract," "The Law of Torts," \&c. Demy 8vo. 1908.

108.

"Of the execution of the work we can speak in terms of the highest praise. The language is simple, concise, and clear." $-L m w$ Hagnsine.

"Praiseworthy in design, scholarly and complete in execntion."-sat. Revien.

* All standard Law Workx are kepe in stock, "w levo calf und other bindings. 
PATENTS.-Edmunds' Law and Practice of Letters Patent for Inventions.-By Lewis Edmunds, Esq., K.C. Second Edition. By T. M. Stetkns, Esq., Barrister-at-Law. Roy. 8vo. 1897. 1l. 128. Edmunds' Patents, Designs and Trade Marks Acts, 1883 to 1888, Consolidated with an Index. Second Edition. By Lxwas. Edxunds, Esq., K.C., D.Sc., LL.B. Imp. 8vo. 1895. Net, 28. $6 d$. Johnson's Patentees' Manual,-Sixth Edition. By JAMrs Jomsson, Esq., Barrister-at-Law ; and J. Hranky Jomson, Solicitor and Patent Agent. Demy 8vo. $1890 . \quad 10$ s. $6 d$. Johnson's Epitome of Patent Laws and Practice. Third Edition. Crown 8vo. 1900.

Morris's Patents Conveyancing.-Being a Collection of Precedents. in Conveyancing in relation to Letters Patent for Inventions. With Dissertations and Copious Notes on the Law and Practice. By Robert Morris, Esq., Barrister-at-Law. Royal 8vo. 1887. 1l. 5s.

Rushen's Critical Study of the Form of Letters Patent for Inventions.-By Percy C. Rushen, Esq., Chartered Patent Agent. Demy 12mo. 1908.

Net, 3s. $6 d$.

Thompson's Handbook of Patent Law of all Countries,-By Wm. P. Thompson. Fourteenth Edition. 12mo. 190S. Net, 2s. 6d. Thompson's Handbook of British Patent Law. Fourteenth Edition. 12 mo. 1908.

Net, $6 d$.

PAWNBROKING.-Attenborough's Law of Pawnbroking, with the Pawnbrokers Act, 1872, and the Factors Act, 1889, and Notes thereon. By Charles L. Attenborough, Esq., Barristerat-Law. Post 8vo. 1897.

Net, 3 s.

PEERAGE LAW.-Palmer's Peerage Law in England. With an Appendix of Peerage Charters and Letters Patent (in English). By Sir Francis Beaufort Palmer, Bencher of the Inner Temple, Author of "Company Precedents," \&c. Royal 8vo. 1907. 12s.6d.

PLEADING.-Bullen and Leake's Precedents of Pleadings in Actions in the King's Bench Division of the High Court of Justice, with Notes. Sixth Edition. By CrkIn Dopd, Esq., K.C., and T. Willes Chitry, Esq., Barrister-at-Law, a Master of the Supreme Court. Royal 8vo. 1905.

1l. $18 s$.

"The standard work on modern pleading." - Law Journal.

Eustace's Practical Hints on Pleading.-By Alex. Avderson Eustace, Esq., Barrister-at-Law. Demy 8vo. 1907.

"Especially uscful to young solicitors and students of both branches of the legal profession."-Law Times, May 11, 1907.

Odgers' Principles of Pleading and Practice in Civil Actions in the High Court of Justice.-Sixth Edition. By W. Brakr: ODGERs, LL.D., K.C., Recorder of Plymouth, Author of "A Digest of the Law of Libel and Slander." Demy 8vo. 1906. 12s.6d.

"The student or practitioner who desires instruction and practical guidance in our modern system of pleading cannot do better than possess himself of Mr. Odgers' book." -Law Journal.

POISONS.-Reports of Trials for Murder by Poisoning.-With Chemical Introductions and Notes. By G. Lathas Brownk, Esq., Barrister-at-Law, and C. G. Stwwart, Senior Assistant in the Laboratory of St. Thomas's Hospital, \&c. Demy 8vo. 1883. 12s. 6d.

** All standard Law, Works are kept in Stock, in law calf and other bindings. 
POLICIES.-Farrer.-Vide "Vendors and Purchasers."

POOR LAW SETTLEMENT.-Davey's Poor Law Settlement and Removal. By Herbert Davey, Eeq., Barrister-at. Law. Demy 8ro. 1908.

"Will be found invaluable by lezal and political students of the complex fabric of our Poor Laws." - "xford Chronicle.

"The law of the subject is most industriously and lucidly set out in this volume."-The Spectator.

POWERS.-Farwell on Powers,-A Concise Treatise on Powers. Second Edition. By Grorge Farwelt, Esq., Q.C. (now a Lord Justice of Appeal), assisted by W. R. ShrLdon. Esq.. Barristerat-Law. Royal 8vo. 1893.

1l. 58 .

PRINCIPAL AND AGENT - Wright's Law of Principal and Agent. By E. Blackwoon Wright, Esq., Barrister-at-Law. Second Edition. Demy 8vo. 1901.

$18 s$.

"May with confidence be recommended to all legal pructitioners as an accurate and handy text book on the subjects comprised in it." - Solicitors' Journal.

PRIVY COUNCIL LAW.-Wheeler's Privy Council Law: A Synopsis of all the Appeals decided by the Judicial Committee (including Indian Appeals) from 1876 to 1891. By Groras Wheeler, Esq., Barrister-at-Law, and of the Judicial Department of the Privy Council. Royal 8vo. 1893.

1l. $11 s .6 d$.

PRIZE CASES.-Reports of Prize Cases determined in the - High Court of Admiralty, before the Lords Commissioners of Appeals in Prize Causes, and before the Judicial Commiltee of the Privy Council, from 1745 to 1859.-Edited by E. S. Roscoz, Esq., Barrister-at-Law and Admiralty Registrar. 2 Vols. Royal 8vo. 1905.

Net, $2 l .10 s$.

"We gladly acknowledge the excellent judgonent with which Mr. Roscoe has performed his task. The English Prize Cases will be a boon to the student of international law, and in times of naval warfare to the practitioner."-Law Journal.

PROBATE.-Nelson's Handbook on Probate Practice (NonContentious), (Ireland),-By Howard A. Nelson, Esq., Barristerat-Law. Demy 8vo. 1901.

$128.6 d$.

Powles and Oakley on Probate,-Fourth Edition. Part I. THE LAW. By L. D. Powles, Esq., Barrister-at-Law, District Probate Registrar for Norwich. Part II. THE PRACTICE. Contentious Practice. By W. M. F. Watertos, Esq., Barrister-at-Law, of the Probate Registry, Somerset House. Non-Contentious Practice. By E. Lovell Mavsbringr, Esq., of the Probate Registry, Somerset House. Demy 8vo. 1906.

1l. $10 s$.

" This is a practical book by practical men, and a very complete guide to the law and practice of probate."-Solicitors' Journal.

PROPERTY.-See also " Real Property."

Raleigh's Outline of the Law of Property.-Demy 8vo. 189u. 7s.6d.

Strahan's General View of the Law of Property. - Fifth Edition. By J. A. Strahan, assisted by J. Sinclair Baxter, Esqra., Barris. ters-at-Law. Demy 8vo. 1908.

$12 s, 6 d$.

"The student will not easily find a better general view of the law of property than that which is contained in this book." - Solicitors' Joumal.

"We know of no better book for the class-room."-Law Times.

PUBLIC MEETINGS.-Chambers' Handbook for Public Meetings.-Including Hints as to the Summoning and Management of them, and as to the Duties of Chairman, \&c., \&e., and Kules of Debate. Third Edition. By Grorga F. Chambrrs, Eisq., Barristerat-Law. Royal 8vo. 1907.

Net, 28. 6d.

$\because$ All standard Law Works are kept in Strick, in law calf and other bindings. 


\section{QUARTER SESSIONS.-See also "Criminal Law."}

Pritchard's Quarter Sessions.-The Jurisdiction, Practice, and Procedure of the Quarter Sessions in Judicial Matters, Criminal, Civil, and Appellate. Second Edition. By Joseph B. MatThews and V. Grafaum Milward, Esqrs., Barristers-at-Law. Demy 8vo. 1904.

Published at 1l. 118. 6d.; reduced to net, 158 .

RAILWAY RATES.-Darlington's Railway Rates and the Carriage of Merchandise by Railway.-By H. R. DarLnNerox, Esq., Barrister-at-Law. Demy 8vo. 1893.

12. 58 .

Russell's Railway Rates and Charges Orders. The Law under the Railway Rates and Charges Orders Confirmation Acts, 1891 and 1892, and the Railway and Canal Traffic Act, 1894, with Explanatory Notes and Decisions.-By Harold Russert, Esq., Barrister-at-Law. Royal 8vo. 1907.

10. $6 d$.

"Useful both to the officials of railway companies and to the latter's customers."-Yorkshire Post.

"Every branch of the subject is treated in a clear and succinct manner." Western Morning News.

RAILWAYS. - Browne and Theobald's Law of Railway Com. panies.-Being a Collection of the Acts and Orders relating to Railway Companies in Great Britain and Ireland, with Notes of all the Cases decided thereon. Third Edition. By J. H. Barfour Brownr, Esq., one of His Majesty's Counsel, and Frank Batfour Browne, Esq., Barrister-at-Law. Royal 8vo. $1899 . \quad 2 l .28$.

"Contains in a very concise form the whole law of railways."-The Times.

"It is difficult to find in this work any subject in connection with ruilways which is not dealt with."-Law Times.

"Practitioners who require a comprehensive treatise on railway law will find it indispensable."-Law Journal

Disney's Law of Carriage by Railway,-Second Edition. By HenrY W. Dissex, Esq.. Barrister-at-Law. Demy xvo. 1909. 78. 6d.

"We can commend it to all students of this branch of the law."-Larw Notes.

"A very iuteresting and useful epitome of the branch of law to which it relates." - Solicitors' Journal.

"Contains much usetul information, and can be cordially recommended to the lawyer."-Lav Times.

Powell's Relation of Property to Tubu Railways.-By MaURICR Powell, Eeq., Barrister-at-Law. Demy 8vo. 1903. Net 18. 6 d.

RATES AND RATING.-Castle's Law and Practice of Rating.- Fourth Edition. By Edward JaMrs Castuk. Esq., one of His Majesty's Counsel, \&c. Royal 8vo. $1903 . \quad 1 l .58$.

"A compendious treatise, which has earned the goodwill of the Profession on account of its conciseness, its lucidity, and its accuracy."-Law Times.

Hamilton and Forbes' Digest of the Statutory Law relating to the Management and Rating of Collieries.-For the use of Colliery Owners, Viewers and Inspectors. By H. B. Haxs Hamilton and Urquhart A. Forbes, Esqrs., Barristers-at-Law. Demy 8vo. 1902. Net, 178. 6d.

"An eminently practical work."-Lavo Times.

REAL PROPERTY.-Carson's Real Property Statutes, comprising, among others, the Statutes relating to Prescription, Limitation of Actions, Married Women's Property, Payment of Debts out of Real Estate, Wills, Judgments, Conveyancing, Settled Land, Partition, Trustees. Being a Tenth Edition of Shelford's Real Property Statutes. By T. H. Carson, Esq., K.C., and H. B. Bompas. Esq., Barrister-at-Law. Royal 8vo. 1902.

"Absolutely indispensable to conveyancing and equity lawyers."

"The labours of the editor and assistant-editor must have been immense, and the congratulations of both branches of the profession on the production of such a useful work, so skilfully prepared, are earned by both editors and publishers." - Law Notes.

*** All standard Law Works are kept in Stock, in law calf and other bindings. 
REAL PROPERTY-continued.

De Villier's History of the Legislation concerning Real and Personal Property in England during the Reign of Queen Victoria.-Crown 8vo. 1901 .

$3 s .6 d$.

Digby's History of the Law of Real Property, Fifth Edition. Demy 8vo. $1897 . \quad$ 128. 6d.

Leake's Digest of the Law of Property in Land.-Second Edition. By A. E. RANDall, Esq., Barrister-at-Law, Editor of "Leake on Contracts," \&c. Royal 8vo. $1909 . \quad$ (Nearly ready.) 20s.

Lightwood's Treatise on Possession of Land: with a chapter on the Real Property Limitation Acts, 1833 and 1874.-By JoHN M. Ligurwood, Esq., Barrister-at-Law. Demy 8vo. 1894. 158.

Maclaurin's Nature and Evidence of Title to Realty. A Historical Sketch. By Richard C. Machaurin, EsQ., of Lincoln's Inn. Demy 8vo. 1901.

Shelford's Real Property Statutes,-Vide "Carson."

Smith's Real and Personal Property,-A Compendium of the Law of Real and Personal Property, primarily connected with Conveyancing. Designed as a Second Book for Students, and as a Digest of the most useful learning for Practitioners. Sixth Edition. By the AUtzor and J. Trugrrax, LL.M., Barrister-at-Law. 2 vols. Demy 8vo. 1884.

$2 l .28$.

" $A$ book which he (the student) may read over and over again with proflt and pleasure."-Law Times.

Strahan.-Vide "Property."

REGISTERED LAND.-Vide "Land Transfer" and "Yorkshire Registries."

REGISTRATION.-Rogers,-Vide "Elections."

Fox and Smith's Registration Cases. (1886-1895.) Royal 8vo.

Smith's (C. Lacey) Registration Cases. Vol. I. (1895-1905.) Royal 8vo. Calf, net, 2l. 14s.

* Parts sold separately. Prices on application.

Smith's (C. Lacey) Registration Cases. Vol. II., Part I. (19061907.) Roy. Svo. Net, 5s. Part II. (1907-1908.) Roy. Svo. Net, 5s.

REPORTS.-Vide "English Reports."

REQUISITIONS ON TITLE.-Dickins, - Vide "Conveyancing."

REVERSIONS.-Farrer,-Vide "Vendors and Purchasers."

RIVERS POLLUTION.-Haworth's Rivers Pollution,-The Statute Law relating to Rivers Pollution, containing the Rivers Pollution Prevention Acts, 1876 and 1893, together with the Special Acts in force in the West Riding of Yorkshire and the County of Lancaster, and Practical Forms. Second Edition. By CharLes Joseph HAworth, Solicitor, B.A. (Cantab.), LL.B. (London). Roy. $12 \mathrm{mo.}$ 1906.

Net, 10s. 6d.

ROMAN LAW.-Abdy and Walker's Institutes of Justinian, Translated, with Notes, by J. T. ABDY, LL.D., and the late BryaN W ALEKR, M.A., LL.D. Crown 8vo. 1876.

168.

Abdy and Walker's Commentaries of Gaius and Rules of Ulpian. With a Translation and Notes, by J. T. ABDY, LL.D., late Regius Professor of Laws in the University of Cambridge, and the late Bryan Walkzr, M.A., LL.D. New Edition by Bryan Walkrz. Crown 8vo. 1885.

Barham's Students' Text-Book of Roman Law.-Second Edition. By C. Nrcolas Barhax, Esq., Barrister-at-Law. Demy 12 mo. 1908.

$3 s .6 d$.

"A collection of notes, clearly and simply expressed, upon the principal topics of Roman Law as they are stated in the Institutes of Gaius and Justinian. Neatly arranged, and forms a complete outline of the subject."-Law Notes.

Goodwin's XII. Tables,-By Freprerick Goopwas, LL.D. London. Royal $12 \mathrm{mo} .1886$.

3s. $6 d$.

* * All stardard Law Works are kept in Stock, in law calf and other bindings. 
ROMAN LAW-continued.

Grueber's Lex Aquilia.-The Roman Law of Damage to Property : being a Commentary on the Title of the Digest "Ad Legem Aquiliam" (ix. 2). With an Introduction to the Study of the Corpus Juris Civilis. By Erwin GrukBer, Dr. Jur., M.A. 8vo. 1886. 10s. 6d.

Holland's Institutes of Justinian.-Second Edition. Extra feap. 8vo. 1881.

58.

Holland and Shadwell's Select Titles from the Digest of Justinian.-Demy 8vo. 1881.

148.

Monro's Digest of Justinian.-Translated. By C. H. Monro, M.A. Vol. I. Royal 8vo. $1904 . \quad$ Net, $12 s$.

Monro's Digest IX, 2. Lex Aquilia. Translated, with Notes, by C. H. Monko, M.A. Crown 8vo. 1898 . 5s.

Monro's Digest XIX. 2, Locati Conducti. Translated, with Notes, by C. H. Monko, M.A. Crown 8vo. 1891.

Monro's Digest XLVII. 2, De Furtis. Translated, with Notes, by C. H. Monro, M.A. Crown 8vo. 1893.

Monro's Digest XLI. 1, De Adquirendo Rerum Dominio. Translated, with Notes, by C. H. Monno, M.A. Crown 8vo. '1900. 58.

Moyle's Imperatoris Iustiniani Institutionum Libri Quattuor.Fourth Edition. Demy 8vo. 1903.168.

Moyle's Institutes of Justinian. Translated into English.-Fourth Edition. Demy 8vo. 1906.

$6 s$.

Poste's Elements of Roman Law.-By Gaius. With a Translation and Commentary. Fourth Edition. Demy 8vo. 1904. Net, $16 s$.

Roby's Introduction to the Study of Justinian's Digest, containing an account of its composition and of the Jurists used or referred to therein. By H. J. Rosy, M.A. Demy 8vo. 1886. 98.

Roby's Justinian's Digest.-Iib. VII., Tit. I. De Usufructu, with a Legal and Philological Commentary. By H. J. Roвy, M.A. Demy 8vo. 1884.

Or the Two Parts complete in One Volume. Demy 8vo. 18.

Roby's Roman Private Law in the Times of Cicero and of the Antonines,-ByH.J.Roвr, M.A. 2vols. Demy 8vo. 1902. Net, 30 s.

Sohm's Institutes of Roman Law.-Third Edition. Demy 8vo. 1907.

Net, 168 .

Walker's Selected Titles from Justinian's Digest.-Annotated by the late BrYan W ALKER, M.A., LL.D.

Part I. Mandati vel Contra. Digest xvrr. I. Crown 8vo. 1879. 5s. Part III. De Condictionibus. Digest xIr. 1 and 4-7, and

Digest xmr. 1-3. Crown 8ro. 1881.

Walker's Fragments of the Perpetual Edict of Salvius Julianus. Collected and annotated by BRYAY WALKKR, M.A., LL.D. Crown 8vo. 1877.

$6 s$.

Whewell's Grotius de Jure Belli et Pacis, with the Notes of Barbeyrac and others; accompanied by an abridged Translation of the Text, by W. Wrowkrn, D.D. 3 vols. Demy 8vo. $1853.12 s$. * * All standard Law Works are kept in Stock, in law calf and other bindings. 
RULING CASES.-Campbell's Ruling Cases.-Arranged, Annotated, and Edited by Robrert Caxprelc, of Lincoln's Inn, Esq., Barrister-at-Law, Advocate of the Sootch Bar, assisted by other Members of the Bar. With American Notes by Irvina Brownr, formerly Editor of the American Reports, the Hon. Lronard A. Jowes, A.B., LL.B. (Harv.), with Supplemental Volume to 1907 by Jaxres T. Krean. Royal 8vo. 1894-1908. Complete in 27 Volumes. Half vellum, gilt top. Price for the set, net, $26 l$. ** The Volumes sold separately, net, each $1 l .5 s$.
1.-Abandonment-Actlon.
II.-Aotion-Amendment.
III.-Anolent Light-Banker.
IV.-Bankruptcy-Bill of Lading.
V.-Bill of Salo-Conflict of Laws.
Vi.-Contraot.
VII.-Conversion-Counsel.
VIII._Criminal Law_Deed.
IX.-Defamation - Dramatio and Musical Copyright.
X.-Easement-Estato.
XI.-Estoppol-Execution.
XII.-Executor-Indemnity.
XIII._-infant-Insuranoe.
XIV.-Insurance-Interpretation.
$X V$. - Judge - Landlord and Tenant.
XVI._Larceny-Mandate.
XVII.-Manorial Rlght-Mistake.
XVIII.-Mortgage - Negligence.
$X I X$. - Negligenco-Partnership.
$x x_{1}$. Patent.
XXI._Payment_-Purchase for Value without Notloe.
XXII.-Quo Warranto-Release.
XXIII._Rellef-Sea.
XXIV.-Search Warrant-Telegraph.
-XXV. -Tenant-Wills.
XXVI.-Table of Cases; Index.

XXVII.-Supplementary Volume, bringing the Work down to 1907.

THIS SERIES PRESENTS-

The best English Decisions (in full),

From the earlier Reports to the present time,

Grouped under topics alphabetically arranged.

UNDER EACF TOPIC IS GIVEN-

A "Rule" of law deduced from the cases;

The early or "leading" case (in full);

English notes abstracting collateral cases ;

American notes.

THE OBJECT OF THE SERIES IS-

To state legal principles clearly,

Through cases of accepted authority,

With sufficient annotation

To aid the application of these principles to any given state of facts.

"The series has been maintained at a high level of excellence."The Times.

\section{Extract8 from Press Notrces.}

"A Cyclopædia of law .... most ably executed, learned, accurate, clear, concise; but perhaps its chief merit is that it impresses on ns what the practising English lawyer is too apt to forget-that English law really is a body of principles."-The British Review.

"One of the most ambitions, and one of the most generally useful legal works which the present century has produced."-Literature.

"A perfect storehouse of the principles established and illustrated by our case law and that of the United Btates."-Law Times.

"The general scheme appears to be excellent, and its execution reflects the greatest credit on everybody concerned. It may, indeed, be said to coustitute the high-water mark of the science of book-making."-Saturday Review.

"A work of unusual value and interest."-Solicitors' Journal.

"The English Ruling Cases seem generally to have been well and carefully chosen, and a great amount of work has been expended. . . Great accuracy and care are shown in the preparation of the Notes."-Law Quarlerly Review.

\section{Supplemental Volume.}

"Those who have included in their library Mr. Campbell's collection of leading cases will find this an indispensable addition to the verics, for it contains all the new matter-English and American - which has grown up round the selected authorities since the issue of the original twenty-six volumes."-Law Journal, August 1st, 1908.

* All standard Lawo Works are kept in Stock, in law calf and other bindings. 
SALES.-Blackburn on Sales. A Treatise on the Effect of the Contract of Sale on the Legal Rights of Property and Possession in Goods, Wares, and Merchandise. By Lord BuackBurn. 2nd Edit. By J. C. Graham, Esq., Barrister-at-Law. Royal 8vo. $1885 . \quad 1$ l. 18. * * A new Edition is in preparation.

SALVAGE.-Kennedy's Treatise on the Law of Civil Salvage. -By The Right Hon. Lord Justice Krannedy, a Lord Justioe of Appeal. Second Edition. By A. R. KENNEDy, Esq., Barrister-atLaw. Royal 8vo. $1907 . \quad 15 s$.

"The whole subject is explained in the present work in a manner at oncelucid and interesting." -Solicitors' Journal, June 8, 1907.

SETTLED LAND.-Vide "Conveyancing" and "Forms."

SHERIFF LAW.-Mather's Compendium of Sheriff and Execution Law. Second Edition. By Phimp E. Matrer, Solicitor and Notary, formerly Under-Sheriff of Newcastle-on-Tyne. Royal 8vo. 1903.

1l. 10 s.

"We think that this book will be of very great assistance to any persons who may fill the positions of high sheriff and under-sheriff from this time forth. The whole of the legal profession will derive great advantage from having this volume to consult."-Law Times.

SHIPPING.-Carver,-Vide "Carriers."

Marsden's Digest of Cases relating to Shipping, Admiralty, and Insurance Law, down to the end of 1897.-By Regrisum G. MARSDin, Esq., Barrister-at-Law, Author of "The Law of Collisions at Sea." Royal 8vo. 1899. 11.108.

Pulling's Shipping Code; being the Merchant Shipping Act, 1894 (57\& 58 Vict. c. 60). With Introduction, Notes, Tables, Rules, Orders, Forms, and a Full Index.-By Alexander Pulurva, Esq., Barrister-at-Law. Royal 8ro. 1894. Net, 7s. 6d.

Temperley's Merchant Shipping Acts,-By RoBERT TEMPERLEY, Esq., Barrister-at-Law. Second Edition, comprising the Merchant Shipping Acts, 1894 to 1907, with Notes, and an Appendix of Orders in Council, Rules and Regulations, Official Forms, \&c. By the Author (now a Solicitor of the Supreme Court), and Hubert Stuart Moore, Esq., Barrister-at-Law, assisted by AlFred Bucknisl, Esq., Barrister-at-Law. Royal 8vo. 1907.

11. $10 s$.

"The book is a monument of industry, careful comparison, and exact knowledge, and nothing has been spared to make the Acts intelligible to all willing to understand them, but to many of whom, perhaps, opportunity for prolonged study is denied."-Law Quarterly Review, January, 1908.

SIERRA LEONE. - Rules of the Supreme Court of the Colony of Sierra Leone. Royal 8vo. 1908. Net, $3 s .6 d$.

Ordinances of the Colony of Sierra Leone.-Vol. I. 1811-1899. Royal 8vo. $1908 . \quad N e t, 2 s .6 d$.

SLANDER.-Odgers.-Vide "Libel and Slander."

SMALL HOLDINGS,-Aggs' Small Holdings and Allotments Act, 1907. With Explanatory Introduction and Notes.By W. Hanbory Aggs, Esq., Barrister-at-Law. Royal 8vo. 1908.

Net, $1 s, 6 d$.

Johnson's Small Holdings and Allotments,-Second Edition. By George Arthor Johnson, Esq., Barrister-at-Law. Royal 8vo. 1909. Net, $16 s$.

Spencer's Small Holdings and Allotments Act, 1908. With Explanatory Notes. By A. J. Spencer, Esq., Barrister-at-Law, Author of "Agricultural Holdings Acts, \&c." (In the press.).

SOLICITORS. - Cordery's Law relating to Solicitors of the Supreme Court of Judicature. With an Appendix of Statutes and Rules, the Colonial Attornies Relief Acts, and Notes on Appointments open to Solicitors, and the Right to Admission to the Colonies, to which is added an Appendix of Precedents. Third Edition. By

A. Cordrry, Esq., Barrister-at-Law. Demy 8vo. 1899. 1l. 18.

"The leading authority on the law relating to solicitors."-Law Journal.

"A complete compendium of the law."-Law Times.

* * All standard Law Works are kept in Stock, in law calf and other bindings. 
SPECIFIC PERFORMANCE. - Fry's Treatise on the Specific Performance of Contracts. By the Right Hon. Sir Edward Fry. Fourth Edition. By W. D. Rawurss, Esq., K.C. Royal 8vo. 1903.

11. $16 s$.

"The leading authority on its subject."-Law Journal.

"Mr. Rawlins has acquitted himself of his responsible task with signal ability."-Law Times.

STAMP LAWS.-Highmore's Stamp Laws.-Being the Stamp Acts of 1891 : with the Acts amending and extending the same, including the Finance Act, 1902, together with other Acts imposing or relating to Stamp Duties, and Notes of Decided Cases; also an Introduction, and an Appendix containing Tables showing the comparison with the antecedent Law. Second Edition. By Sir NatranikL Joseph Highmork, Assistant-Solicitor of the Inland Revenue. Demy 8vo. 1902. 10s. $6 d$.

"The recngnized work on the suhject."-Law Quarterly Review.

"This edition, like the former one, will be found of the greatest use br solicitors, officers of companies, and men of business."-Law Journal.

"A very comprehensive volume, fulfilling every requirement." -Justice of the Peace.

“Mr. Highmore's 'Stamp Law*' leaves nothing undone."-The Civilian.

STATUTES, and vide "Acts of Parliament."

Chitty's Statutes.- The Statutes of Practical Utility. from the earliest times to 1894 , with Supplemental Volumes to 1907 inclusive. Arranged in Alphabetical and Chronological Order: with Notes and Indexes. Fifth Edition. By J. M LeLr, Esq., Barrister-at-Law. Royal 8vo. 15 Volumes. 1894-1907.

$171.17 \mathrm{~s}$.

Supplementary Volume, 1895 to 1901. Consolidated with Index. May be had separately. $2 l .2 s$.

Supplementary Volume, 1902 to 1907. With Index. May be had separately.

"'To those who already posess 'Chitty's Statutes' this new volume is indispersable."--Low Notes.

Annual Supplement for 1908.

(In the press.)

Annual Supplements. Separately:-1895, 5s. 1896, 10s. 1897, 5s. $1893,7 s .6 d$. $1899,7 s .6 d$. 1900, 7s. 6d. 1901, 7s. 6d. 1902, 7s. $6 d$. $1903,7 s .6 d$. 1904,7s.6d. 1905,78.6d. 1906, 7s.6d. 1907,10s.6d. "It is a book which no public library should be without." Spectator.

"A work of permanent value to the practising lawyer."-Solicitors" Journal.

"Indispensable in the library of every lawyer."-Saturday Reviev.

"To all concerned with the laws of England, Chitty's Statutes of Practical $U$ tility are of essential importance, whilst to the practising lawyer they are an absolnte necessity."-Law Times.

"The lawyer's Bible is the 'Statutes of Practical Utility'-that they are his working tools, even more than accredited text-books or 'authorised reports.' More than one judge has been heard to say that with the 'Statutes of Practical Jtility' at his elbow on the bench he was apprehensive of no difficulties which might arise."The Times.

STATUTE LAW.-Wilberforce on Statute Law. The Principles which govern the Construction and Operation of Statutes. By E. Wilberforck, Esq., a Master of the Supreme Court. 1881. 18ג.

- All standard Law Works are kept in Stock, in law calf and other bindings. 
STOCK EXCHANGE.-Schwabe and Branson's Treatise on the Laws of the Stock Exchange.-By WaLter S ScHWaBR and G. A. H. Branson, Enqri., Barristers-at-Law. Demy 8vo. 1905.

$12 s .6 d$.

"This book gives a clear and comprehensive account of the constitution of the London Stock Exchange and of the nature of Stock Ex rhange transactions, as well as of the legal rules applicable in respect thereof."-Law Quarterly Review.

"A clear and prartical account of the method in which the business of the Stock Exchange is conducted, and of the law relating thereto." - Law Times.

"The best guide we know to the nature of Stock Exchange transactions." The Spectator.

"That the treative will be acceptahle to lawyers and laymen alike we have no doubt. We have satisfied ourselves that the legal portion is a sound, and in all respects satisfactory, piece of work."-Law Journal.

SUCCESSION.-Holdsworth and Vickers Law of Succession, Testamentary and Intestate, Demy 8vo. $1899 . \quad 10 s .6 d$.

SUMMARY CONVICTIONS.-Paley's Law and Practice of Summary Convictions under the Summary Jurisdiction Acts, 1848-1899; including Proceedings Preliminary and Subsequent to Convictions, and the Responsibility of Convicting Magistrates and their Officers, with the Summary Jurisdiction Rules, 1886, and Forms,-Eighth Edition. By W. H. Macnascara, Esq., a Master of the Supreme Court, and Rasph Nevirue, Esq., Barrister-at-Luw. Demy 8vo. $1904 . \quad$ 1l. $5 s$

TAXPAYERS' GUIDES. - Vide “House," “Income," and "Land Tax."

THEATRES AND MUSIC HALLS.-Geary's Law of Theatres and Music Halls, including Contracts and Precedents of Contracts.-By W. N. M. GEARY, J.P. With Historical Lutroduction. By JAMrt WILLIAMs, Esq.. Burrister-at-Law. 8vo. 1885. 5s.

TITLE.-Jackson and Gosset.-Vide "Iuvestigation of Title."

TORTS.-Addison on Torts.-A Treatise on the Law of Torts ; or Wronge and their Remedies. Eighth Edition. By Wrumax EdWARD Gordon, Esq., and Walter Hussey Griffith, Esq., Barristers-atLaw. Royal Svo. 1906.

1i. $18 s$.

"As a practical goide to the statutory and case law of torts the present edition will be founo very relianle and complete."-Solicitors' Journal.

" 'Addison on Torts' is ess'ntially the practitioner's text-book. The learned pditors have done their work exceedingly well, and the eighth edition of 'Addison' aill no doubt enjoy the favour of the legal profession in us hish a degree as any of its predecessors." - Law Journal.

"The elghth e lition is the most important that has been issued of late years, mainly because it supplies a want that has been widely felt in regard to negligence and illegal distress. Chapter I. hav been entirely recast, and numerous changes will be found throughout the text. It is but natural that this edition should be larger than its predecessors, but this increase is fully justified in every маจ."-Law Times.

Bigelow's Law of Torts.-By Melviluk M. Bigknow, Ph.D. Harvard. Thirl Edition. Demy 8vo. 1908. 12s. 6d.

Kenny's Selection of Cases Illustrative of the English Law of Torts.-By C. S. Kenvy, LL.D., Barrister-at-Law. Demy 8 vo. 1904.

Net, 12s. 6d.

** All standard Law Works are kept in Stock, in law calf and other bindings. 
TORTS-continued.

Pollock's Law of Torts: a Treatise on the Principles of Obligations arising from Civil Wrongs in the Common Law. Eighth Edition. Ey Sir Fredrrick Powock, Bart., Barrister-at-Law. Author of "Principles of Contract," "A Digest of the Law of Partnership," \&c. Demy 8vo. 1908.

1l. 5 s.

"Concise, logically arranged, and accurate."-Law Times.

"Incomparably the best work that has been written on the subject."Literature.

"A book which is well worthy to stand beside the companion volume on 'Contracts.' Unlike so many law-books, especially on this subject, it is no mere digest of cases, but bears the impress of the mind of the writer from beginning to end." - Law Journal.

Radcliffe and Miles' Cases Illustrating the Principles of the Law of Torts.-By Francis R. Y. Radcurfe, Esq., K.C., and J.C. Mrres, Esq.. Barrister-at-Law. Demy 8vo. 1904. Net, 12s.6d.

TRADE MARKS.-Sebastian on the Law of Trade Marks and their Registration, and matters connected therewith, including a chapter on Goodwill; the Patents, Designs and Trade Marks Acts, 1883-8, and the Trade Marks Rules and Instructions thereunder; with Forms and Precedents; the Merchandize Marks Acts, 1887-94, and other Strtutory Ensctments: the United States Statutes, 1870-82, and the Rules and Forms thereunder; and the Treaty with the United States, 187i. By Lrwis Born Skrastuar, Esq., Barrister-at-Law. Fourth Edition. By the Author and Harry Barrd Hexsrng, Esq., Barrister-at-Law. Royal 8vo. 1899.

* A new Edition is in preparation.

"Stands alone as an authonty npon the law of trade-marks and their registration."-Lave Journal.

"It is rarely we come across a law book which embodies the results of years of careful investigation and practical experience in a branch of law, or that can be unhesitatingly appealed to as a standard authority. This is what can be said of Mr. Sebastian's bonk." - Solinitnrs' Journal.

Sebastian's Law of Trade Mark Registration under the Trade Marks Act, 1905.-By Lewis Bord Sebastias, Esq., Barristerat-Law. Royal 8vo. 1906.

78. $6 d$.

"Mr. Sebastian has written a brief, though instructive, Introduction to the Act of 1905 , which has consolidated and amended the law relating to the Registration of Trade Marks, and his notes are clear and adequate."-Laic Journal.

Sebastian's Digest of Cases of Trade Mark, Trade Name, Trade Secret, Goodwill, \&c., decided in the Courts of the United Kingdom, India, the Colonies, and the United States of America. By Lewis Boyp Skbastuas, Esq., Barrister-at-Law. 8vo. 1879. 1l. 1s.

"Will be of very great value to all practitioners who have to advise on matter connected with trade marks."-Snlicilors' Journal.

TRADE UNIONS. - Assinder's Legal Position of Trade Unions. By G. F. Assivoer, Esq., Barrister-at-Law. Demy $12 \mathrm{mo}$. 1005 .

Net, 2s. 6d.

"In this little work Mr. Assinder has with great clearness and ability sketched the legal position of trade unions." - Law Journal.

Draper's Trade Unions and the Law.-By WARwick H. Draper, Fsq., Barrister-at-Law. Demy 8vo. $1906 . \quad$ Vet, $6 d$.

Pennant's Trade Unions and the Law.-By D. F. Pessast, Esq., Barrister-at-Law. Royal 12mo. 1905.

* All standard Law Works are kept in Stock, in law calf and other bindings. 
TRAMWAYS.- Robertson's Law of Tramways and Light Railways in Greas Britain (3rd Editum of Sutton's "Tramuay Acts of the United Kingdım"): comprinmy the Statutes relating to Tramways and Light Railnays in England and Scotland, with full Notes; the Tramw ays and Light Ruilways Rules; the Regulatious, By-Laws and Memoranda issued by the Board of Trade; the Standirg Order of Parliament; the General Orders under the Private Legislation Procedure (Srotland) Act, 1899: and Dissertations on Locus Standi and Rating. By G. Stuart Robertson, M.A., Esq., Barrister-at-Law. Royal 8vo. $1903 . \quad 1$ l. 58.

TRANSVAAL.-Transvaal Proclamations, 1900-1902. Revised. 1904. 6vo. $1 l .5 \mathrm{~s}$

TRUSTEES (Corporate).-Allen's Law of Corporate Executors and Trustees. By Ernest King Allkn, Esq., Barristerat-Law. Demy 8vo. 1906.

$6 s$.

TRUSTS AND TRUSTEES.-Ellis' Trustee Acts, including a Guide for Trustees to Investments. By ARTHUR LRR Eur.18, Esq., Barrister-at-Law. Sixth Edition. By L. W. ByrNe, Esq., Barristerat-Law. Roy. 12mo. 1903.

68.

Godefroi's Law Relating to Trusts and Trustees.-By the late Hanky Goderror, of Lincoln's Inn. Esq.. Barrister-at-Law. Third Edition. By Whitmore L. Richards and James I. Stiringe, Esqrs., Barristers-at-Law. Royal 8vo. 1907.

"There is the same scrupulous attention to every detail of trustees' riphts and dutics, the same critical analysis of all the nuances of trusts and other equitable $i$ torests, the same careful comparison of all the decisions-sometimes apparently cor flicting - on the different branches of this complicated subject, which made p evious fditions so useful even to the expert." - Law Journal.

UNITED STATES.-Stimson's Law of the Federal and State Constitutions of the United States. By FrEDERIs Jesup STIMsON, Esq., Author of "American Statute Law," \&c. Royal 8vo. 1908.

Net, $15 s$.

VENDORS AND PURCHASERS.-Dart's Vendors and Purchasers.-A Treatise on the Law and Practice relating to Vendors and Purchasers of Real Estate. By the late J. Hrengy DarT, Esq. Seventh Edition. By Benjamin L. Cherry, one of the Editors of "Prideaux's Precedents in Conveyancing," G. E. Tyrrewr, Arthur Dicrson and IsaAc Marshatl, assisted by L. H. Elpunnstone, Esgr8., Barristers-at-Law. 2 vols. Royal 8vo. 1905.3 3l. 158.

"There are traces throughout the book of an unstinted expenditure of skill and labour in the preparation of this edition which will maintain the position of the book as the foremost anthority."-Law Quarterly Review.

"The work remains a great conveyancing classic."-Law Journal.

"To the young and to the staid practitioner having any pretensions to conveyancing work, we unhesitatingly say, Procure a copy at once."-Law Students' Journal.

"This work is a classic. and quite beyond our criticism. All we can do is to let our readcrs know, and to advise them to put a copy on their shelves without delay."-Law Notes.

Farrer's Precedents of Conditions of Sale of Real Estate, Reversions, Policies, \&c.; with exhaustive Footnotes, Introductory Chapters, and Appendices.-Second Edition. By Frederick EnWard FarRer, Esq., Barrister-at-Law. Royal8vo. 1909. (Neurlyready.) 168.

"Mr. Farter has written a rare thing - a new book which will be of real value in a conveyaucer's library."-Law Journal.

"The notes are tssentially practical."-Law Times.

Turner's Duties of Solicitor to Client as to Sales, Purchases, and Mortgages of Land.-Second Edition. By W. L. HAcon, Esq., Barrister-at-Law. Demy 8vo. 1893.

* All standard Law Works are kept in Stock, in law calf and other bindings. 
VENDORS AND PURCHASERS-continued.

Webster's Law Relating to Particulars and Conditions of Sale on a Sale of Land.-Third Edition. By W. F. Webster, Esq., Barrister-at-Law. Roy. 8vo. 1907.

"Conveyancers will assuredly find this volume of much ralue."-Law Times.

WAR, DECLARATION OF. -Owen's Declaration of War, A Survey of the Positiou of Belligerents and Neutrals, with relative considerations of Shipping and Marine Insurance during War. By Dovoras Owes, Esq., Barrister-at-Law. Demy 8vo. 1889. 1l. ls.

Owen's Maritime Warfare and Merchant Shipping. - A Summary of the Rights of Capture at Sea By Dodglas Owrs, Esq.. Barrister-at-Law. Demy 8ro. $1898 . \quad$ Net, 2s.

WAR ON LAND.-Holland's Laws of War on Land.-By T. E. Hollasd, E*q., K.C. Dems sro. 1908. Jet, 6s.

WATER.-Bartley's Metropolis Water Act, 1902.-By Douglas C. BarTLEY, Esq., Barrister-at-Law, Author of "Adulteration of Food." Rnyal 12mo. 1903.

$6 s$.

WEIGHTS AND MEASURES.-Bousfield's Weights and Measures Acts, 1878 to 1904 . With the Board of Trude Regulations and other Statutes relating thereto. BF W. ERIC Bous. Frem, Esq., Barrister-at-Law, wirh a Preface by 'W. R. Bousfiem, Esq., K.C. Demy 8ro. 1907.

6.8 .

WILLS. - Theobald's Concise Treatise on the Law of Wills.Seventh Edition. By H. S. Tzzoвand, Eaq., one of His Majesty's Counsel. Royal svo. 1908.115.

"Indispensable to the cunvesancing practitioner."-Law Times.

" Comprehenare though easy $t$, use, aud we advase all cuoveyancers to get a cops of it without loss of time."-Law Journal.

" Of great ability and value. It bears on every page traced of care and sound iudgment."-Soliciemrs" Journal.

Weaver's Precedents of Wills.-A Collection of Concise Precedents of Wills, with Introduction and Notes. Second Edition. By Charles Wraver, B.A., Solicitar. Demy 8vo. 1904.

"The notes, like the forms, are clear and, wa far as we bave tested them, accurate ... cannot fail to be of servive to the young practitioner." - Law Times.

WINDING UP.-Palmer's.-Tide "Company Law."

Pellerin.-Vide "French Law."

WORKMEN'S COMPENSATION. - Vide "Employers" Liability."

Knowles' Law Relating to Compensation for Injuries to Workmen.-Being an Exposition of the Workmeu's Compensation Act, 1906, and of the Case Law relevant thereto. Second Edition, including the Workmeo's Compensation Rules and Forms, 1907, aunotated, together with all the Treasury Regulatious and Orders made under the Act by the Home Office. Treasury. and Chief Registrar of Friebdly Societies. By C. M. Kxowles, Esq., Barrister-at-Law. Demy 8vo. 1907 .

Yet, $8 s$.

" There is an excellent iatroduction, and the various sections of the Act are fully annotated. The book is a timey ons, and should be rppreciated by both branches of the legal proffxsi in "-Law Times.

"Mr. Knowles has produced an able cummentary on the Act "-I as Journal.

"The subject is treated in a ksrisfactury way." - Soliritnrs" Journal.

Robertson and Glegg's Digest of Cases under the Workmen's Compensation Acts. Royal 8*o. 1902. Net, 10s.

WRONGS. -Addison. Bigelow. Kenny, Pnllock, Radclif e and Miles. - Fide "Torts."

YORKSHIRE REGISTRIES.-Hawurth's Yorkshire Registries Acts, 1884 and 1885.-With Furms, Rules and Practical Nutes on the Registration of Documents. By Charles J. Haworti, Solicitur. Ruyal $12 \mathrm{mo} .1207$.

Net, $5 s$.

$\because$ All standard Law Works are kept in Stock, in law calf and other bindings.

STEVENS AND SONS, LD., 119 120, CHANCERY LANE, LONDON. 


\section{THE}

\section{LAW QUARTERLY REVIEW.}

EDITED BY

\section{Sir FREDERICK POLLOCK, Bart., M.A., LL.D.,}

Corpus Professor of Jurisprudence in the University of Oxford, late Professor of Common Law in the Inns of Court.

Vols. I. to XXIV.; with GENERAL INDICES to Vols. I. to XX. Royal 8vo. 1885-1908. Price, each, 12s., cloth lettered.

**Annual Subscription, net 12s. Ga., postage free. Single numbers, 5s. each.

The objects of the Review include-

The discussion of current decisions of importance in the Courts of this country, and (so far as practicable) of the Culonies, the United States, British India, and other British Possessions where the Common Law is administered.

The consideration of topics of proposed legislation before Parliament.

The treatment of questions of immediate political and social interest in their legal aspect.

Inquiries into the history and antiquities of our own and other systems of law and legal institutions.

Endeavour is also made to take account of the legal science and legislation of Continental States in so far as they bear ou general jurisprudence, or may throw light by comparison upon problems of English or Anserican legislation.

The current legal literature of our own country receives careful attention; and works of serious importance, both English and foreign, are occasionally discussed at length.

“The 'Law Quarterly' (January, 1909) is well paeked with learned dissertations as well as with Notes and Reviews which may be considered the lighter side of the issue. Legal experts may always count on finding some article on their special subject-more general readers will fiud an article by the Editor on 'Goverument by Committees in England.' "_ :alurday Revieu, January ..0, 1949. 


\section{THE LAW JOURNAL REPORTS.}

Edited by JOHN MEWS, Esq., Barrister-at-Law.

"All reports made by gentlemen of the Bar, and published on their responsibility, are equally regular. There is no superiority in the reports of the Council of Law Reporting. Counsel are as much entitled to cite the one as the other."

The Master of the Rolis. Times L. R., May 21, 1887.

Extract from Preface to "Bexjanix ox SALEs." jth Edition, 1906.

"The Editors wish to bear testimony to the sustained excellence of the Law Journal Reports, which they have consulted in all cases of difficulty, and upon which alone in some instances the statement of a case has been based. These Reports have been especially valuable in diuclosing the diutinction between similar cases, or the particular ground on which a decision was rested-matters which have been much fucilitated by the practice of setting out the plendings at longth. Refereuce to there Reports has not unfrequently been the meaus of clearing up obscurities which the other Reports had failed to dispel."

\section{Advantages of Subscribing to these Reports :}

\section{References.}

References to these REports are to be found in the prineipal Law Text Books.

\section{Simplicity of Arrangement.}

There is only One Volnme in the yeur for exch Division of the Courts. The LAw Joursal RkPorts and Statutes for each year may be conveniently bound in three vols. The system of citatiou has nut been muterially altered for 79 years.

\section{Eamly Publication.}

Under the New Muvagement all importunt Cases aro reported promptly.

\section{Revision by Judges.}

Nearly all the Judges revise the reports of their judgments.

\section{Digest.}

Mrws Axvea Digrat of all Riported Decisinn of the Superior Cuurts (issued Qunrterly, price 175.) is supplied to Subsribers at the reduced rate of 6s. per annum.

\section{Moderate Price.}

Aunual Subcription. with the Statetes (otticially pinted by the Kux's Printers), is only $£ 3: 45$. per anum : or bound in 3 vols., half-calf, $\mathcal{E 3}: 19$ s.

\section{Thin Paper Edition.}

Forming One liandy Volume per unsum, $\mathbf{E 3 : 4 5 . , ~ o r ~ i n ~ h a l f - c a l f , ~}$

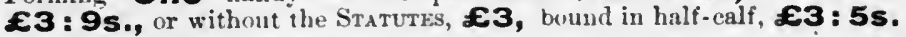

\section{Weokly Newspaper.}

Suberibers have the additioual advantage of obtaining, for a further Subscrip-

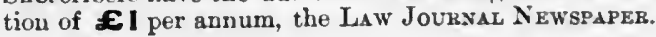

* * Remitlances to be made payable to Stevens axd Sons, Limited. 


\section{PREPARING FOR PUBLICATION.}

Burge's Colonial Law. Commentaries on Colonial and Foreign Laws generally and in their Conflict with each other,-A new Edition. By A. Woon Renton, Esq., Puisne Judge, Ceylon, and G. G. Philumore, Esq., Barrister-at-Law. In 5 vols. Royal 8 vo. (Vol. III. in the press.)

*** Full prospectus sent on application.

Carver's Treatise on the Law relating to the Carriage of Goods by Sea,-By Thomas Gilbert Carver, Esq., K.C. Fifth Edition. By Robert Alderson Wrioht, Esq., Barrister-at-Iaw.

(In the press.)

Cockburn's Law of Private Railway Sidings and Private Traders' Traffic.-By John Henry Cockburv, Esq., Solicitor, Author of "The Law of Coal, Coal Mining and the Coal Trade."

(Nearly ready.)

English Reports, -A complete Re-issue of all the Decisions prior to 1866 in about 150 Volumes. Sixth Series. King's Bench and Queen's Bench.

*** Full prospectus on application.

(Now publishing.)

Farrer's Precedents of Conditions of Sale of Real Estate, Reversions, Policies, \&c.-Second Edition. By Frederick EDward Farrer, Esq., Barrister-at-Law.

(Nearly ready.)

Fuller's Law relating to Friendly Societies.-Third Edition. By Frank Baden Fuller, Esq., Barrister-at-Law. (In preparation.)

Hood and Challis' Conveyancing and Settled Land Acts, and some other recent Acts affecting Conveyancing. With Commentaries. By H. J. Hoon and H. W. Challis. Seventh Edition. By Percy F. WheEler, Esq., Barrister-at-Law. (Nearly ready.)

Lawes' Law of Compensation for Industrial Diseases.-By EDwARD Thond'on Hill Lawes, Esq., Barrister-at Law.

(In the press.)

Leake's Digest of the Law of Property in Land.-Second Edition. By A. E. Randall, Esq., Barrister-at-Law.

(Nearly ready.)

Lush's Law of Husband and Wife.-Third Edition. By W. Hossey Griffith, Esq., Barrister-at-Law.

(In preparation.)

Palmers Company Precedents,-Part II. Winding-up Forms and Practice.-Tenth Edition. By Sir Francis Beaufort Palmer, Bencher of the Iuner Temple.

(In preparation.)

Prideaux's Precedents in Conveyancing, incorporating Wolstenholme's Forms and Precedents. - Twentieth Edition. By BenJamis Lennard Cherry and Reoinald Brdpinaton, Esqrs., Barristers-atLaw.

(In preparation.)

Rogers' Law of Registration.-Seventeenth Edition. By MaURICE Powell, Esq., Barrister-at-Law.

(In the press.)

Russell's Treatise on Crimes and Misdemeanors. - Seventh Edition. By William F. Crales aud L. W. Kershaw, Esqrs., Barristers-atLaw.

(In the press.)

Sebastian's Law of Trade Marks. - By Lewis Boyd Sebastian, Esq., Barrister-at-Law. Fifth Edition.

(In preparation.)

Smith's Analysis of the Principles of Equity.-By H. Antrirur Sмгти, Esq., Barrister-at-Law.

(In the press.)

Spencer's Small Holdings and Allotments Act, 1908, with Explanatory Notes.-By Aubrey J. Spencer, Esq., Barrister-atLaw.

(In preparation.) 


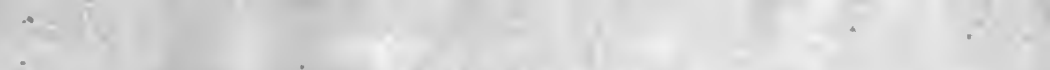

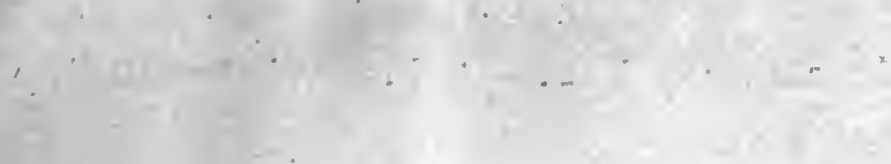

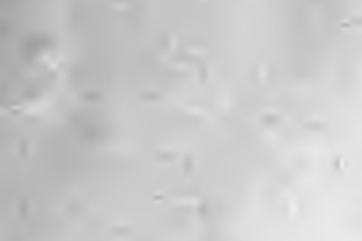




\section{$\mathbf{F}$}

This book is DUE on the last date stamped below

$\mathbf{P}$

C:

S]

$\mathbf{P}$

DEC 6 1949 MAR 191965

P OCT $30195 \%$ LOURL AHE 23 1965

MAY 151954

RENEWHKE SCr 1 S 1965

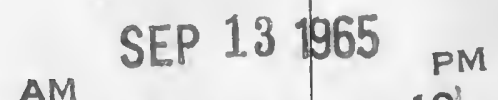

W Ar. 2161

St ieb 1462

Si Mar 14.62 Apr $46^{2}$

Sr May $18-62$

$\mathbf{W}$

Be

Form L-9-15m-2,'36

Williams' Law relating to Legal Representatives.-Being a Concise Treatise on the Law of Executors and Administrators, as modified by the Iand 'Transfer Act. 1897. By SYDNEY E. WILLIAMS, Barrister-at-Law. 1hemy beo. 1908 . Price 9s. cloth.

Cornish's District Councils.-A concise Guide to their Powers and Duties. By H. D. CORNISH, Barrister-at-Law. Demy 8vo. 1908. I'rice is. 6d. cluth.

Davey's Poor Law Settlement and Removal.-By Herbert DAVEY, Barrister-at-Law. Demy Svo. 1908. Price 9s. cloth.

Burge's Colonial Law.-Commentaries on Colonial and Foreign Laws Generally and in their Conflict with each other. New and Enlarged Edition. By A. WOOD RENTON. Puisne Judge. Ceylon, and G. G. PHILliMORE, Barrister-at-Law, assisted by Experts in the several systems of Law. Five Iols.

Royal 8eo. Price, net, 8l. 8s. cloth. 


\section{VERBATIM REPRINT ANNOTATED.}

C \ULTATIVE COMMITTEE :

[Great Britain ;

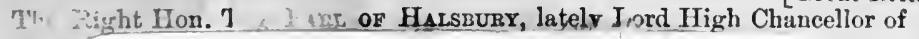

of England ;

The

POLTOWIN

iouncil, $\mathrm{C}$

ERIES :

This $\mathrm{s}$

omplete 1

nd Suitl

50 volun

Imost rer

be privil

sports.

$7 \mathrm{pe}$

The I

aginat

nd d.g

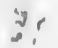

rdds. Privy

$S$ BENCH

ely.

, $156.5 . \quad A$

uding Best

fewer than

and would

will havo

invaluable

lo style of

he original

text-books

lete In

$£ 22$.

I) vois

1809 to

13 : 10 s.

$187 \overline{2,0}$

557 to

CHA

t0: 10 s.

$1866), c$

8 vols.

ROL

$£ 12$.

te in

$16 \frac{\mathrm{VI}}{\mathrm{vo}}$

£24.

1865),

K I

vols.

I, 30s.

(Vols.

Idon. 
